University of Massachusetts Amherst

ScholarWorks@UMass Amherst

Doctoral Dissertations 1896 - February 2014

$1-1-2005$

\title{
The contradictory imperatives of New Deal banking reforms.
}

Ellen D. Russell

University of Massachusetts Amherst

Follow this and additional works at: https://scholarworks.umass.edu/dissertations_1

\section{Recommended Citation}

Russell, Ellen D., "The contradictory imperatives of New Deal banking reforms." (2005). Doctoral Dissertations 1896 - February 2014. 2388.

https://doi.org/10.7275/fzfb-zj90 https://scholarworks.umass.edu/dissertations_1/2388

This Open Access Dissertation is brought to you for free and open access by ScholarWorks@UMass Amherst. It has been accepted for inclusion in Doctoral Dissertations 1896 - February 2014 by an authorized administrator of ScholarWorks@UMass Amherst. For more information, please contact scholarworks@library.umass.edu. 
7.

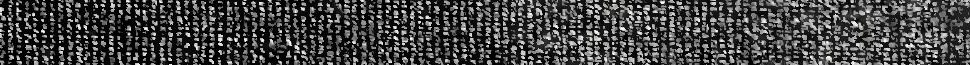

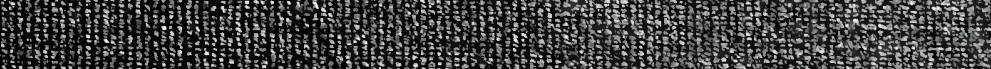

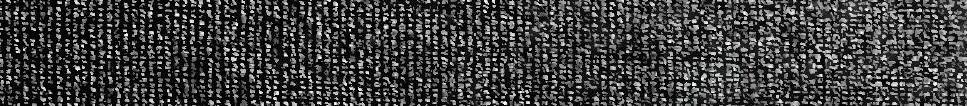

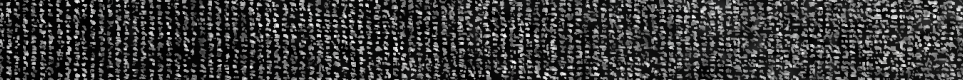

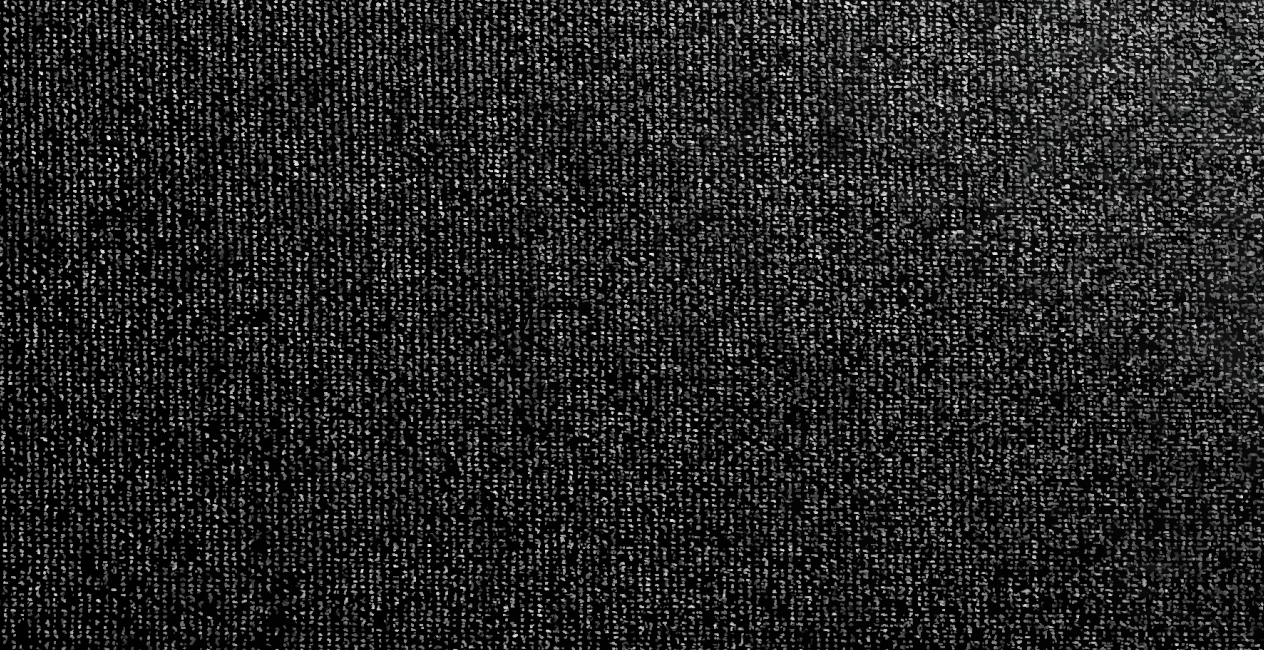

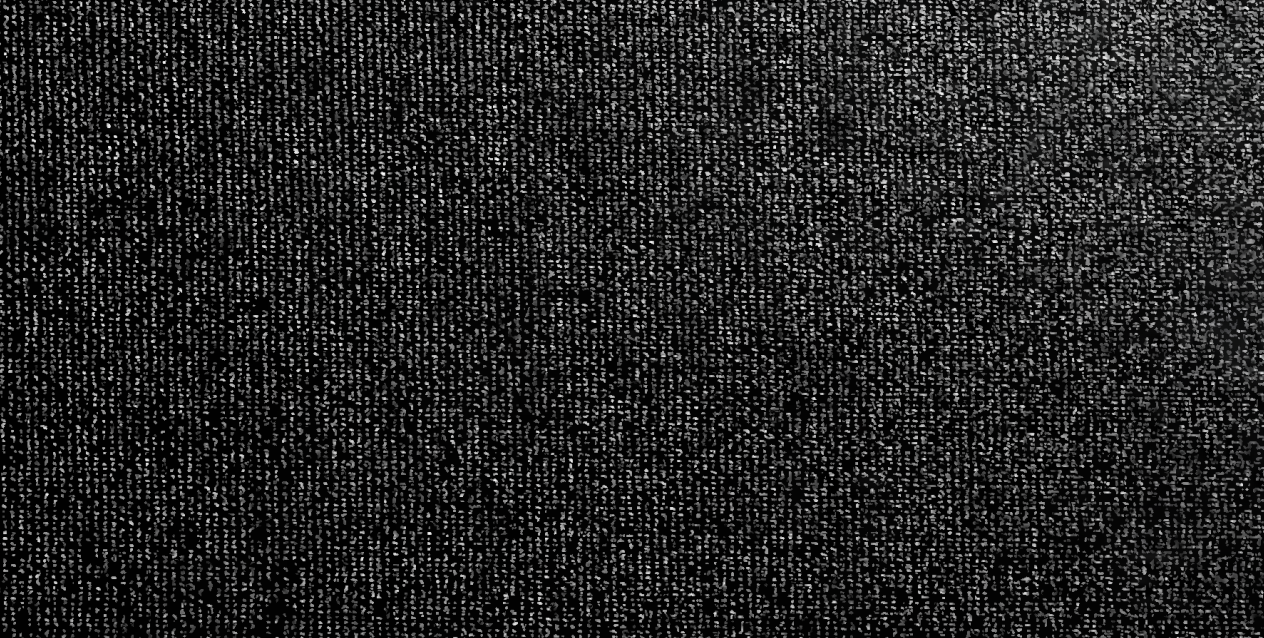
in: Howhom

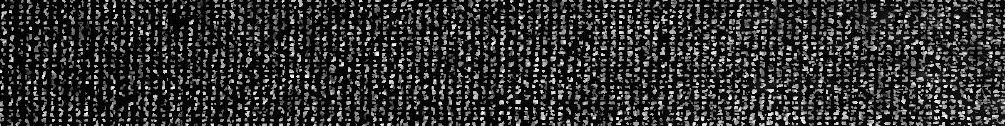

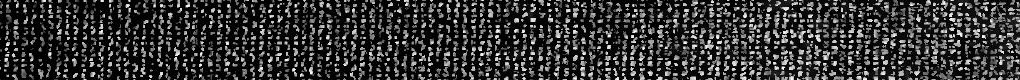
1.13m,

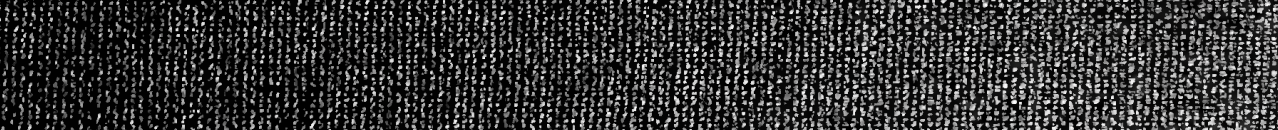

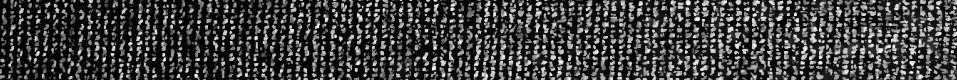

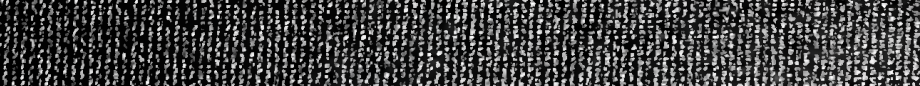
mh; 
The Contradictory Imperatives Of

New Deal Banking Reforms

A Dissertation Presented

by

ELLEN D. RUSSELL

Submitted to the Graduate School of the

University of Massachusetts Amherst in partial fulfillment

of the requirements for the degree of

DOCTOR OF PHILOSOPHY

February 2005

Economics Department 
(C) Copyright by Ellen D. Russell 2005

All Rights Reserved 
THE CONTRADICTORY IMPERATIVES OF

NEW DEAL BANKING REFORMS

A Dissertation Presented

by

ELLEN D. RUSSELL

Approved as to style and content by:

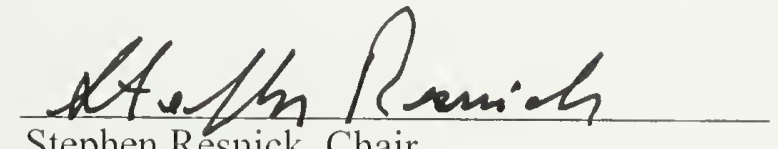

Stephen Resnick, Chair
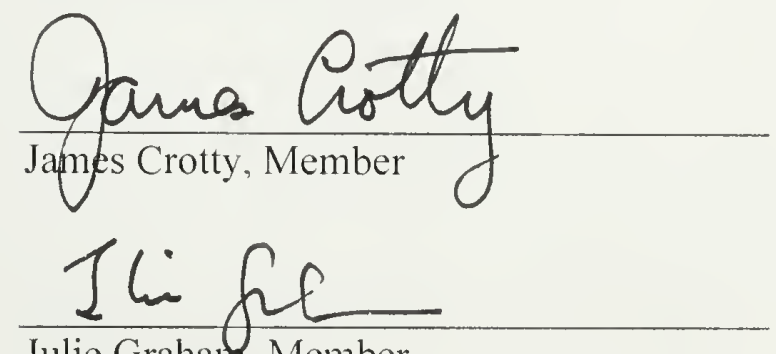

Julie Grahan, Member
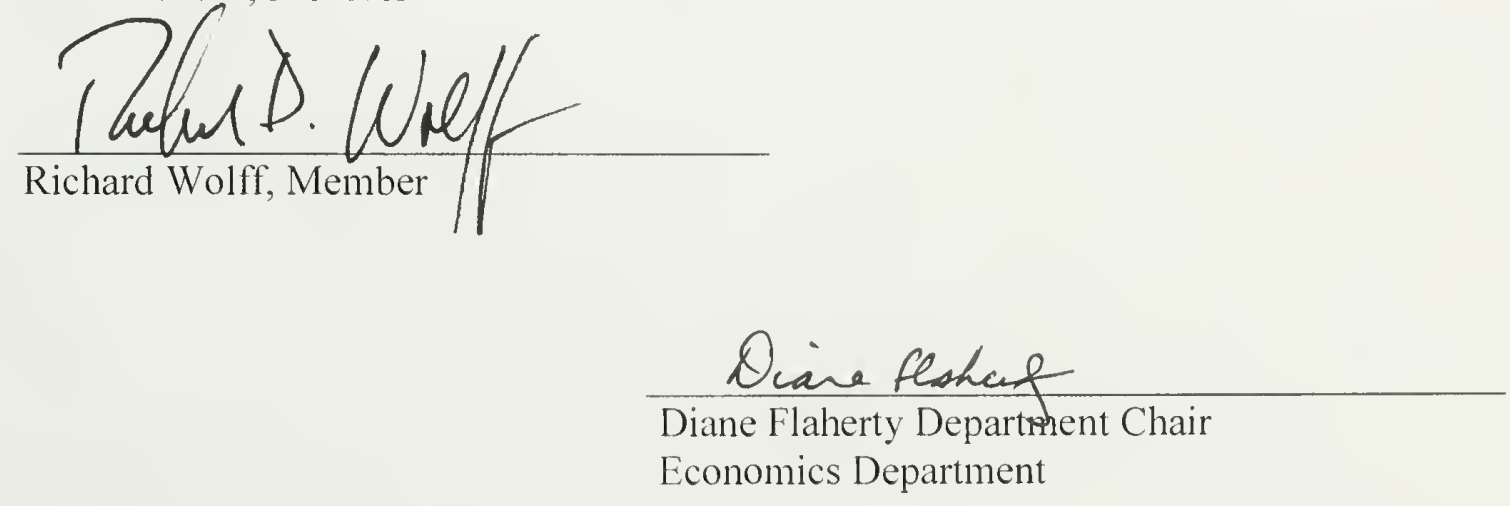


\section{DEDICATION}

This dissertation is written with gratitude for the unique environment at the economics department at the University of Massachusetts at Amherst. I appreciate everyone, faculty and students, who has sustained this department since the early 1970s, and made it a vibrant and stimulating place to consider many approaches to the study of economics.

I dedicate this dissertation to Lillian M. Russell, my grandmother, whose political activities in the 1930s have inspired me to learn from past struggle. 


\section{ACKNOWLEDGMENTS}

The committee that supervised this dissertation has been an immensely supportive. My supervisor, Stephen Resnick, has an unusual gift for provoking me to reach just a little farther, and then supporting me as I try to come to terms with the implications of the reaching. Jim Crotty has generously stood by me as I engaged with perspectives both close to - and farther from- his heart, and I have benefited enormously from his perceptive questioning. I am particularly thankful to Julie Graham for offering her insight and energies to my voyage through this doctorate in ways that were certainly above the call of duty. Rick Wolf has spent much time with me and I am grateful for all of it, and he has often used his playful humor to enable me to find my way to realizations that I might have been unable to grasp otherwise.

In addition to my committee members, I am grateful to Jane d'Arista for sharing her enormous expertise in financial matters. I am grateful for the support of Leo Panitch, who under the auspices of the Canada Research Chair provided me with support and a stimulating environment to write my dissertation. The Canadian Centre for Policy Alternatives has also generously provided me with many opportunities to attend to the business of dissertation-writing. 


\section{ABSTRACT \\ THE CONTRADICTORY IMPERATIVES OF NEW DEAL BANKING REFORMS \\ FEBRUARY 2005 \\ ELLEN D. RUSSELL, B.A., UNIVERSITY OF TORONTO \\ M.A., QUEEN'S UNIVERSITY \\ Ph.D., UNIVERSITY OF MASSACHUSETTS AMHERST \\ Directed by: Professor Stephen Resnick}

This dissertation examines the contradictory imperatives of New Deal banking reforms to explore both their notable successes and subsequent erosion. From the perspective of overdeterminist Marxian class analysis, we explore the conflicting objectives of New Dealers as they reflect the logic of a nascent Keynesianism. We argue that the Keynesian project for economic growth and stability required the availability of cheap money capital to promote vigorous investment. However, the provision of money capital on attractive terms can exert downward pressure on the profitability of financial capitalist firms, and commercial banks in particular. The potentially detrimental implications of this agenda on commercial bank profitability was particularly dire given the crisis in commercial banking that prevailed during the great depression. This dilemma obliged New Deal banking reforms to institute a complex pastiche of policies, some of which enhanced and some of which constrained the profitability of commercial banks.

We examine certain aspects of New Deal banking legislation, such as the GlassSteagall Act (which prohibited the blending of commercial banking with other financial capitalist activity such as investment banking), the creation of deposit insurance, and the imposition of interest rate controls, to discern their contradictory implications for 
commercial bank profitability. In conducting this analysis, the dissertation has applied and extended the class analysis of financial capital provided by overdeterminist Marxism in order to discern the various struggles both among financial capitalists and between productive and financial capital shape the profitability of financial capital.

Using this framework, we argue that the success of the New Deal banking reforms in the post-war period initially produced a "pax financus" in which the competitive struggles amongst financial capital were moderated. However, the success of these reforms also produced incentives to undermine the New Deal regulatory framework via a regeneration of competitive struggles among financial capitalists. As these struggles intensified, financial innovations designed to circumvent regulatory restrictions changed the conduct of commercial banking and other financial capitalist activity. As these developments progressed, there has been a resurgence in the diversified financial conglomerates (financial holding companies) reminiscent of those that flourished just prior to the great depression. 
ACKNOWLEDGMENTS

ABSTRACT

LIST OF TABLES

LIST OF FIGURES.

\section{CHAPTER}

1. THE NEW DEAL FINANCIAL REFORMS AND THE

CONTRADICTIONS OF THE KEYNESIAN AGENDA

FOR ECONOMIC GROWTH AND STABILITY 1

Revisiting The New Deal: A Problemitization Of The

Radical Left's Relationship To Capitalist Reform

Keynesianism, The New Deal And The Role Of Financial Reform ...................... 5

An Overdeterminist Marxian Perspective

On The Keynesian Reform Agenda

The Contradictory Implications Of "Finance As Servant":

The Class Analytics Of The Subsumed Class Struggle

Between Productive And Financial Capital

The Subsumed Class Struggle Among Financial Capitalist Firms:

New Deal Financial Reforms From The Perspective

Of Commercial Banks.

2. A CLASS ANALYSIS OF FINANCIAL CAPITAL:

AN INITIAL LOOK AT THE CONTRADICTIONS OF THE

KEYNESIAN FINANCIAL REFORM AGENDA

Introduction

Subsumed Class Struggles Between Productive And Financial Capital:

A Preliminary View Of The Contradictions Of Keynesian Agenda For

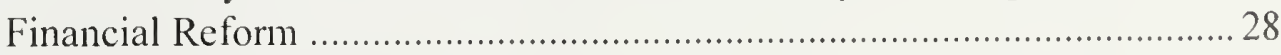

The Keynesian Financial Reform Agenda

And The Question Of Competition Among Financial Capitalist Firms

Non-Class Elements Of Financial Capitalist Activity

A Further Overdeterminant Of Subsumed Class Struggles Involving

Financial Capital

Potential Financial Capitalist Responses To Support Their Profitability

In The Face Of The Keynesian Financial Reform Agenda... 
3. THE CLASS ANALYTICS OF COMMERCIAL BANKING:

FURTHER CONSIDERATIONS IN THE SUBSUMED CLASS

STRUGGLES INVOLVING FINANCIAL CAPITAL ....

Introduction .58

The Class Analysis Of Commercial Banking

Using Conventional Banking Data To Conduct A Class Analysis Of

Commercial Banks. 65

Unique Aspects Of Commercial Banks And Their Impacts On

Subsumed Class Struggles

The State And Regulation Of Commercial Banking: Further

Overdeterminants To Subsumed Class Struggle Among

Financial Capitalists

Commercial Banking And The Diversified Financial Capitalist Firm 82

The Diversified Financial Capitalist Firm And The Keynesian Agenda For Financial Reform 88

4. THE RISE AND SUBSEQUENT REPUDIATION OF THE DIVERSIFIED FINANCIAL CAPITALIST FIRM IN THE 1920s AND EARLY 1930s. 92

Introduction 92

Competition in Commercial Banking: The Legacy of "Free Banking"............. 93 Commercial Banking and the Stock Market Boom of the 1920s 101

Commercial Bank Expansion Into Diversified Financial Capitalist Firms In The Late 1920s....

The Commercial Banking Crisis In The Early 1930s

The Emerging Critique Of Diversified Financial Capitalist Firms In The Early 1930s

Critiques Of Speculation And The New Deal Coalition For Financial Reform

5. THE CONTRADICTORY IMPERATIVES OF NEW DEAL FINANCIAL REFORMS

The Contradictory Imperatives of New Deal Financial Reform

The Glass-Steagall Act And The Prohibition Of Diversified Financial

Capitalist Firms

Enhancing Commercial Bank Profitability Without Increasing The

Costs Of Accessing Money Capital:

A Return To The Two Moments Of Financial Intermediation 
New Deal Supports To Commercial Bank Profitability

In The First Moment Of Financial Intermediation.

The Multiple and Divergent Competitive Effects Of

New Deal Financial Reform

New Deal Financial Reforms And The Advent Of Pax Financus

6. RISE OF BELLUM FINANCUS AND THE CRISIS OF NEW DEAL

FINANCIAL REFORM

From Pax Financus To Bellum Financus:

The Contradictions Of New Deal Financial Reform

And The Transformation Of US Financial Capital

The Inherent Contradictions Of New Deal Financial Reforms

And The Provocation Of Bellum Financus.

Strategies Of Non-Bank Financial Capitalist Firms

To Disrupt Financial Compartmentalization

The Competitive Strategies Of Non-Bank Financial Capitalist Firms

To Lure Deposits Away From Commercial Banks

Bellum Financus And Its Impact On The

Diversification Of Class Processes Within The Firm

Commercial Banks And The Diversification of Capitalist Firms ................... 185

The Repeal of the Glass-Steagall Act

Evaluating New Deal Financial Reforms

In Light Of Their Keynesian Motivations

7. THE TRANSFORMATION OF COMMERCIAL BANKS

DURING THE DECLINE OF NEW DEAL FINANCIAL

COMPARTMENTALIZATION

Commercial Bank Response To The Competitive Threats

During The Erosion Of Financial Compartmentalization 196

Commercial Banking Strategies In The First Moment Of

Financial Intermediation .....

Commercial Banking Strategies In The Second Moment Of

Financial Intermediation

Responses Beyond Traditional Commercial Banking:

Competitive Strategies In The First Moment

Of Financial Intermediation

Supplementing Profitability Beyond Traditional

Commercial Bank Lending

Conclusion: The Illusory Pursuit of Stability 


\section{LIST OF TABLES}

Table

1 A Comparison Of FDIC Revenue Categories And Class Analytic Value Inflow Categories Related To Commercial Bank Profit....

2 A Comparison Of FDIC Expense Categories And Class Analytic Value Outflow Categories Related To Commercial Bank Profit 
Figure

1 Value Inflows and Expenditures of a Generic Financial Capitalist Firm 38

2 Class Analysis Of A Money-Lending Financial Capitalist Firm 46

3 Class Analysis Of Financial Capitalist Firm That Provides

Equity Capital To Productive Capitalist Firms

4 Commercial Banking Value Inflows and Expenditures 60

5 Commercial Banking Profits

6 Class Analysis of Commercial Bank Profits.

7 Numbers Of Commercial Banks Prior To The Great Depression. 95

8 Interest Paid By Commercial Banks On Deposits As A Percentage Of Interest-Related Earnings From Loans And Securities

9 Interest Charged on Customer Loans in Leading Cities 100

10 Corporate Securities Offerings, 1919-1941 102

11 Corporate Securities Issued vs. Commercial Bank Loans Unconnected to Securities. 104

12 Return on Assets of Federal Reserve Member Banks, 1919-1929 106

13 Commercial Bank Loans Made On Securities As A Percentage Of Total Commercial Bank Loans.

14 Return on Assets of Federal Reserve Member Banks 1929-39

15 Failures Of Federal Reserve Member Commercial Banks As A Percentage Of Total Federal Reserve Member Commercial Banks, 1919-1933

16 Bank Deposits, Federal Reserve Member Banks, 1920-1941

17 Numbers of FDIC-Member Commercial Bank Failures 

18 Interest Paid On Deposits Per Dollar Of Deposits Attracted At Federal
Reserve Member Banks .........

19 Total Interest Paid on Deposits At Federal Reserve Member Banks

20 Figure 20 Numbers of FDIC-Insured Commercial Banks, 1934-2001

21 Return On Assets 1933-1999, FDIC -Member Commercial Banks ...

22 MMMF Shares Outstanding As A Percentage Of Commercial Bank Deposits, 1945-1999

23 Pension Fund Total Reserves As Percentage Commercial Bank Deposits

24 Mutual Fund Shares Outstanding As Percentage Commercial Bank Deposits

25 "Deposits", MMMFs, Pension Shares And Mutual Fund Shares As A Percentage Of The Total Financial Assets Of Households, Non-Profit Organizations And Non-Financial Corporate Business

26 The Total Credit Market Assets Of Commercial Banks, Pension Funds, MMMFs And Mutual Funds Relative To Total Credit Market Assets

27 Commercial Paper Outstanding As A Percentage Of Total Commercial Bank Loans Outstanding, $1970-1999$

28 Total Financial Assets Of Finance Companies As A Percentage Of Total Financial Assets Of US-Chartered Commercial Banks. 1970-1999

29 Interest On Deposits In Domestic Offices As A Percentage Of Total Domestic Deposits Of FDIC Member Banks

30 Vault Cash And Reserves Held At Federal Reserve As A Percentage Of The Total Financial Assets Of Us-Chartered Commercial Banks

31 Non-Interest Income As A Percentage Of Interest Income For FDICInsured Commercial Banks . 1960-1999

32 Return On Assets Of FDIC-Member Commercial Banks Including And Excluding Non-Interest lncome, 1960-1999 


\section{CHAPTER 1}

\section{THE NEW DEAL FINANCIAL REFORMS AND THE CONTRADICTIONS OF THE KEYNESIAN AGENDA FOR ECONOMIC GROWTH AND STABILITY}

\section{Revisiting The New Deal: \\ A Problemitization Of The Radical Left's Relationship To Capitalist Reform}

The prolonged devastation of the great depression provoked widespread critique of the prevailing economic system. Many of these critiques wrestled with the question of whether capitalism per se was indicted by these cataclysmic economic and social conditions. Faced with the possibility that capitalism itself might be rejected amidst the suffering and turmoil of the great depression, many advocates of capitalism were persuaded of the advisability of embracing economic reforms. "We shall either adopt a plan that will meet the problem of unemployment under capitalism, or a plan will be adopted for us which will operate without capitalism."' Marriner Eccles, depression-era head of the Federal Reserve Board, warned in February of 1933. (in Hyman 1976, 106) In this context, the Roosevelt administration advanced the so-called "New Deal" reforms to address the crisis of the great depression and restore the viability of American capitalism.

President Roosevelt explained in 1936 that his New Deal agenda was intended to preserve the economic status quo by reforming it:

No one in the United States believes more firmly than I in the system of private business, private property and private profit. ... If the Administration had had the slightest inclination to change that system, all that it would have had to do was to fold its hands and wait - let the system continue to default to itself and to the public. Instead ... we acted quickly and drastically to save it. It was because of our belief in private enterprise that we acted quickly and drastically to save it. (in Humphries 1970, 10-11) 
However, many leftists of diverse theoretical proclivities overlooked these explicitly conservative motivations of New Dealers to make common cause with this project of capitalist reform. Leftists who opposed the concentration of economic power often allied with the anti-trust elements of the New Deal, while leftists who critiqued the market allocation mechanism saw commonalties with pro-capitalist advocates of an enlarged role for the state in economic planning. ${ }^{1}$ Leftist that embraced an underconsumptionist understanding of the great depression often endorsed Roosevelt's concerns about inadequate purchasing power. ${ }^{2}$ Norman Thomas, the Socialist presidential candidate in 1932, confirmed this co-incidence between New Deal policies and Socialist party demands, claiming that "... any platform [Roosevelt] had carried out was mine and the socialists rather than his." (Thomas, 1967, 112) Given these points at which New Deal and leftist concerns converged, many leftists of the day hoped that the New Deal would

\footnotetext{
' For example, the biographer of Adolph Berle, the New Deal braintruster and famous co-author of The Modern Corporation and Private Property, explained the alliance between Berle, who "detested" anyone who was "enamoured" of Marxism (ix), and leftists (including Marxists) in the following reference to one particular program of the later New Deal era, the Temporary National Economic Committee (TNEC): "Besides Berle, numerous economists, politicians, bureaucrats, and businessmen took the TNEC seriously. Marxists theorists too envisioned TNEC as an opportunity to invoke socialist planning and achieve political viability amid a mushrooming consensus for state control. In the atmosphere of 1939 , the Left also found the state capitalism of Berle and the punitive taxation of the Brandeisians appealing. Not a few Marxists then considered Keynesian 'compensatory fiscal policy' a reasonable way station on the road to socialism in America. Thus antitrusters, capitalistic planners, and Marxists would all make TNEC in part " a showcase for Keynesian economics'." (Schwarz 1987, 136)

${ }^{2}$ One of Roosevelt's more famous statements in the under-consumptionist vein occurred prior to his election, in May of 1932 when he explained the depression as follows: "'No, our basic trouble is not an insufficiency of capital. It was insufficient distribution of buying power coupled with an oversufficient speculation in production. While wages rose in many of our industries, they did not as a whole rise proportionately to the reward to capital, and at the same time the purchasing power of the great groups of our population was permitted to shrink. We accumulated such a superabundance of capital that our great banks were vying with each other, some of the employing questionable methods, in their efforts to lend this capital at home and abroad."' (Roosevelt 1967, 79)
} 
create an opening through which they might expand upon their radical agendas. Thus these leftist allied themselves with the New Deal reforms despite the public justification of these reforms as a means of preempting demands for more radical measures.

The New Deal reforms are often credited as providing some of the foundations for the period of vigorous post-war economic growth and relative economic stability that is referred to as the "golden age" of welfare state capitalism. But despite the economic and social improvements initiated by New Deal policies, many leftists were ultimately disappointed in their hopes that these reforms might make way for further radical transformation. Not only did these reforms fail to fulfill the aspirations of those who regarded the New Deal as merely a first step towards radical transformation, it has transpired that many of the achievements of the New Deal have been subsequently eroded, reversed and even vilified. In light of these disappointments, this dissertation provides an analysis of both the achievements and limitations of the New Deal in an effort to provoke a rethinking of leftist strategies to pursue radical agendas by allying with capitalist reforms.

Many leftists survey the rise and decline of welfare state capitalism in search of some flaw(s) in the New Deal reforms that, once corrected, would enable the left to seize future opportunities to craft better (and more enduring) economic reforms. This dissertation does not depict the New Deal reforms as afflicted by some policy flaw that later emerged to render these reforms unsustainably dysfunctional. By attending to the complex and sometimes divergent imperatives that confronted New Dealers, we 
acknowledge the considerable sophistication with which the New Deal grappled with a profoundly challenging economic situation. Rather than explaining the downfall of New Deal reforms on the basis of their shortcomings, this dissertation analyzes these reversals of New Deal measures as a consequence of their success. By employing the perspective of overdeterminist Marxian class analysis, this dissertation examines the contradictory imperatives that animated New Deal reform. From this vantage point we argue that the achievements of New Deal economic reforms provoked unintended consequences that ultimately subverted their viability.

While this dissertation focuses on a particular historical incidence of economic reforms to discern their contradictory dynamics, it is intended as a reflection on the attempt to craft economic policy in general. Since contradiction (understood in the overdeterminist sense described below) is ubiquitous, we argue that economic interventions propel factors that both promote and undermine the stated intention of the intervention. No economic intervention, within or outside capitalism, including those advocated by Marxian class analysis, can escape these contradictory dynamics. By the same token, the decision not to intervene also sets in motion similar contradictory dynamics. Since neither action nor refraining from action can escape its own negation, we are obliged to confront the ultimate uncontrollability inherent in policy intervention. By contending that no policy can be crafted that does not also imply its own negation, this dissertation argues that we must abandon the quest to design some optimal set of policies that will be immune from unintended and self-sabotaging consequences. 
By emphasizing the uncontrollability of policy intervention, this is not to say that the left should refrain from making interventions. On the contrary this dissertation is motivated to promote activism (albeit an activism that is not assuaged by hopes of a certainty that does not exist in a universe animated by contradiction). This dissertation regards the bringing to consciousness of the futility of the hope for certainty as an intervention that may support (and also, it must be confessed, undermine) radical anticapitalist alliances. If leftists have been persuaded to make common cause with capitalist exploitation because they perceive that reforms within capitalism offer them a greater likelihood of achieving their goals, then problematizing this aspiration for "successful" policy may promote a rethinking of strategy on the left. By repudiating reassurances that complicity with capitalism offers a greater probability of achieving radical goals, it is hoped that this dissertation will advance the possibilities of embracing the agendas for economic change that include the opposition to capitalist exploitation.

\section{Keynesianism, The New Deal And The Role Of Financial Reform}

Keynesian economic thought was immensely influential among both radicals and others who supported the New Deal. Thus part of our exploration of the contradictions animating New Deal economic reforms requires that we attend to some of the implications of the Keynesian theory that informed them. Although the early stages of the New Deal predate the publication of J.M. Keynes' celebrated The General Theory of Employment Interest and Money, the general principles of Keynesian thought were 
having an impact on policy circles in the early 1930 s. $^{3}$ Federal Reserve officials were cognizant of the principles of counter-cyclical monetary policy prior as of 1922 (as Keynes himself acknowledged), although the deliberate use of fiscal policy came somewhat later. ${ }^{4}$ Moreover, prominent advisors amongst the intellectual leadership of the New Deal claimed to have arrived at Keynesian ideas independently of Keynes. ${ }^{5}$ Thus, despite the varying degrees of self-conscious awareness of Keynesian theory on the part of the architects of New Deal reforms, these early New Deal reforms are portrayed in this dissertation as Keynesian.

The Keynesianism that emerged as hegemonic ${ }^{6}$ attributed economic stagnation and instability within a capitalist economy to inadequate aggregate demand. Keynesianism sought to create a full-employment economic equilibrium by means of state economic intervention to stabilize aggregate demand. Thus Keynesianism offered the possibility of preserving capitalism, while ridding it of its devastating and recurrent

\footnotetext{
${ }^{3}$ Earlier publications of Keynes had sketched out many of the ideas that were further developed in the General Theory. (for example, see Crotty, 1999) Arguably the full theoretical expression of "hegemonic" Keynesianism did not appear until after World War two with the refinement of the "neoclassical Keynesian syntheses" articulated by John Hicks, Paul Samuelson, Lawrence Klein, Franco Modigliani and others.

${ }^{4}$ See A Treatise on Money $(1930,255)$, concerning Keynes' acknowledgement of the use of countercyclical monetary policy at the Federal Reserve. Despite being obliged to abandon balanced budgets and engage in stimulatory government spending early in the depression, the deliberate use of deficits to promote economic recovery began in 1938, according to Arthur Smithies, of the Bureau of the Budget. (in Greer 1958, 54)

${ }^{5}$ Mariner Eccles, chairman of the Federal Reserve in the 1930s, wrote of Roosevelt's brain trust: " I doubt whether any of the men in my room had ever heard of Joln Maynard Keynes, the English economist who has frequently been referred to as the economic philosopher of the New Deal... The concepts I formulated, which have been called 'Keynesianism', were not abstracted from his books, which I had never read.'" (in Mayer 2001, 158)
}

${ }^{6}$ Other interpretations of Keynesianism exist that differ from the Keynesianism that will be discussed below. However, we will refer to the Keynesianism described in this section as "hegemonic"

Keynesianism, in that it was the interpretation of Keynes' work that had such a dramatic impact on both the mainstream of the economic profession and on the design of public policy. 
economic instability and depression, if the means could be found to stabilize aggregate demand. Many leftists were persuaded that they could make common cause with a Keynesianism that opposed economic stagnation and cyclical crises, particularly since many additional demands for redistributive and egalitarian economic and social change might be pursued via Keynesian interventionism.

Keynesianism traced the inadequacy of aggregate demand back to the component of aggregate demand that they deemed to be the most volatile: investment spending. ${ }^{\text {? }}$ Keynesianism concurred with Marxism in the rejection of Say's Law, claiming instead that firms are reluctant to produce if they fear detrimental aggregate demand conditions. Weak or volatile aggregate demand contributes to instability in investment spending (since firms are insecure about their ability to sell their output), and unstable or low investment exacerbates (via the Keynesian multiplier) aggregate demand problems. Thus Keynesians sought to create a virtuous circle in which brisk and stable investment spending would contribute to stabilizing aggregate demand at a level consistent with fullemployment, while strong aggregate demand, buttressed with state initiated countercyclical aggregate demand management, would attenuate the volatility of investment. ${ }^{8}$

\footnotetext{
${ }^{7}$ Keynesian theory regards investment spending as the most volatile component of aggregate demand for a variety of reasons connected to the uncertainty afflicting the investment process itself. Keynesians argue that because investment is largely irreversible and the profitability of any new investment will be determined in an unknowable future, investment spending is a significant commitment undertaken on the basis of expectations about the future. Investment can fluctuate (or stagnate at low levels) according to a host of factors that affect these expectations, including expectations about the future state of aggregate demand.
}

${ }^{8}$ Activist monetary and fiscal policy might simultaneously pursue additional political objectives such as income redistribution or the provision of services to disadvantaged sections of the population 
With the judicious mix of policies to both encourage investment spending and facilitate counter-cyclical state economic intervention, Keynesianism offered the hope that a capitalist economy could be "fine-tuned" to avoid stagnation and economic instability.

Since the New Deal was comprised of a variety of policy interventions that influenced many dimensions of economic activity, only a subset of these reforms can be given thorough consideration in this dissertation. For a variety of reasons, our focus will be on several of the financial reforms implemented by the New Deal. The catastrophic financial crises that characterized the great depression compelled New Dealers to regard the reform of finance as a critical priority. In part this was politically expedient, since financial reform policies enhanced the New Deal's populist credibility by appealing to the popular distrust of financiers. However, the focus on financial reform also follows from the logic of Keynesian economic theory. Given that Keynesianism sought to maintain investment spending at the full employment level, it was obliged to scrutinize the conditions of existence for vigorous investment spending. Since the US economy continued to be organized as a private capitalist economy, the investment decision remained in the hands of private capitalist firms. Keynesian reformers were compelled to address a variety of factors that influenced the firm's investment decision in order to support their investment agenda. One of the factors that shape investment spending is the accessibility and price of external sources of financing for investment projects. ${ }^{9}$ Thus

\footnotetext{
${ }^{9}$ Although firms may be able to generate funds internally to finance their investment projects, we focus here on the role of externally provided funding in the investment process.
} 
New Deal reforms addressed the dramatic disarray of American finance in order to create conditions in which funds would be forthcoming to promote investment spending and thereby enhance aggregate demand.

The external provision of funding for investment projects is generated via the process of financial intermediation, whereby the savings of the economy are collected from savers and allocated among many potential users. ${ }^{10}$ For this reason, advocates of Keynesian financial reform were compelled to pay careful attention to the relationship between "production" (understood as firms which undertake investment) and "finance" (understood as firms which engage in financial intermediation). In order to promote vigorous investment spending, Keynesianism sought to ensure that funding for investment would be readily and cheaply available to the "real" or productive sector of the economy. Often this was understood as creating an environment of low real interest rates, so that prospective investors would pay less to secure borrowed funds and thereby be encouraged to increase their investment spending. ${ }^{11}$ In Keynesian parlance, this goal is sometimes articulated as the prescription that finance should be the "servant" subordinated to the needs of production ${ }^{12}$, meaning that finance should conduct itself to

\footnotetext{
${ }^{10}$ Savings in the economy are not channeled exclusively to private firms engaged in investment. They may be channeled to consumers, the state or to entities abroad. These uses of the economy's savings also affects the investment decision, as when savings that are channeled to consumers act as a stimulus to aggregate demand.

${ }^{11}$ As will be discussed below, their interest rate is the payment made to secure debt capital. However, investment may be financed via the issuing of stock, in which case a different sort of payment (dividends) may be paid to secure equity capital. However Keynesian analysis usually emplasizes the interest rate rather than both forms of payment for access to money capital.

${ }^{12}$ Helleiner $(1994,6)$ claims that "members of this new [Keynesian] alliance favored more interventionist policies that would make finance the 'servant' rather than the "master' in economic and political matters". This sort of "servant" relationship of finance to production is referred to in other ways in Keynesian discourse, as when finance is depicted as having "second class status".
} 
provide access to money capital on terms favorable to the promotion of investment. By shaping financial intermediation in a manner that compelled finance to act as the servant of production, Keynesian financial reforms sought to promote rapid and stable economic growth by supporting the availability of cheap funding for investment.

This dissertation will explore how certain domestic ${ }^{13}$ New Deal financial reforms attempted to shape the process of financial intermediation in accordance with the Keynesian prescription that finance ought to play a servant role vis à vis production. The argument is presented that a number of financial reforms contained in the Banking Acts of 1933 and 1935 reflected or were consistent with financial restructuring in the service of this Keynesian objective. The first, and possibly most famous of these reforms was the Glass-Steagall Act, which dramatically reorganized financial intermediation in the United States. The restructuring of financial intermediation accomplished by New Deal financial regulation created some of the conditions of existence for the so-called "pax financus" (Gart 1994, 4), a long post-war period in which the conduct of financial intermediation is often perceived as supportive of the golden age of Keynesian welfare state capitalism. Yet as time passed, these financial reforms began to unravel. The dissertation will argue that the ultimate subversion of New Deal financial reforms is a reflection of the contradictory imperatives that animated the Keynesian agenda, namely the attempt to promote capitalist economic growth and stability by compelling finance to act as servant to production.

\footnotetext{
${ }^{13}$ We leave aside international interventions, particularly the later Bretton Woods agreement, that pursued Keynesian objectives in the international arena.
} 


\section{An Overdeterminist Marxian Perspective On The Keynesian Reform Agenda}

There are various divergences and convergences between the Keynesian economic theory and the overdeterminist Marxian class analysis employed in this dissertation. However, we will emphasize two important differences between these theoretical traditions. First, unlike Keynesian theory, the Marxian focus on the production, appropriation and distribution of surplus labor emphasizes exploitation. Secondly, the overdeterminist theory of causation employed by the Marxian class analytic approach differs from the theory of causation employed by Keynesian discourse. These differences generate differing perspectives on economic growth and crises, terminological differences, as well as differing attitudes towards the purposes of studying economic history.

The Marxian class analytic character of this dissertation diverges from the Keynesian analysis outlined above because its focus on surplus labor highlights the exploitative character of the capitalist class process. The presence or absence of the concept of exploitation has implications for the terminology employed in both of these theories. Some Keynesian terms, such as "investment", do not have an exact equivalent in Marxian analysis. In Keynesian analysis, investment refers to spending by firms on new plant and machines as well as spending on new housing. Thus the Keynesian term "investment" is not equivalent to the Marxian term "accumulation", which is defined as the purchase of additional means of production and labor power. The Keynesian term "investment" focuses attention on the creation of physical capital only, and overlooks any concomitant expansion in the scope of exploitation. In addition, the Keynesian term 
"investment" does not focus on the class character of the spending. Investment spending may include the purchase of means of production in productive and unproductive capitalist firms and in non-capitalist class structures. Since the dissertation will be conducted using Marxian terminology, we will consider the Keynesian category of investment as a rough approximation of the Marxian term accumulation while acknowledging the above caveats. Thus the Keynesian goal of promoting economic growth and stability via vigorous investment spending can be restated in Marxian terms as the pursuit of rapid and stable capitalist accumulation.

From a Marxian perspective, the rapid and stable capitalist accumulation sought by advocates of Keynesian welfare state interventionism is fueled by the exploitation of workers, and results in the extension of exploitative capitalist class relations to greater numbers of workers. Given that Marxist class analysis condemns the capitalist class process for this exploitative organization of production, it cannot endorse any attempt to insulate workers from the devastating effects of economic stagnation and volatility in return for exploitation on an ever larger scale (and possibly at a greater rate of exploitation as well). Moreover, a Marxist perspective regards even this Faustian bargain as illusory, since Marxism relates the exploitative character of the capitalist class process to the crisis tendencies that debilitate capitalism. The production, appropriation and distribution of surplus labor in an exploitative class structure is afflicted by both fundamental and subsumed class conflicts ${ }^{14}$ that can generate debilitating economic instability and stagnation. Thus the success of any policies designed to promote capitalist

\footnotetext{
${ }^{14}$ The Marxian class analytic terminology of fundamental class, subsumed class, and non-class processes are explained in Resnick and Wolff (1987).
} 
economic growth and stability will set in motion crises that undermine this goal. For these reasons, Marxists reject Keynesians' retention of an exploitative class process in pursuit of economic growth and stability. This is not to say that the abolition of exploitative class processes is ipso facto, any guarantee of rapid and stable economic growth. Such an assertion would be contrary to the insistence of overdeterminist Marxian class analysis that economic growth creates its antithesis, economic stagnation, while economic stability carries with it the germination of economic instability. The Marxian class analytic project prefers to confront the incessant possibilities of economic stagnation and instability within a class process that is not exploitative, in hopes that such a non-exploitative class process might generate the conditions of existence for preferable approaches to handling these dilemmas that are inherent in economic life.

The Marxian surplus labor perspective condemns New Deal reforms in that they did not challenge capitalist exploitation. Marxists of this theoretical disposition may well share others' demands for diverse economic and social transformation, including such "non-class" 15 economic transformations as the creation of a more egalitarian distribution of economic power, income, or property, or non-market allocative mechanisms.

However, class analytic Marxists predicate their support of these non-class agendas on the demand that these agendas be partnered with the opposition to capitalist exploitation. In the absence of a critique of exploitation, class analytic Marxists fear that these progressive economic changes may be complicit with exploitation. Instead of creating the

\footnotetext{
${ }^{15}$ Where "non-class" economic changes refers to changes that do not address "class" understood as the production, appropriation and distribution of surplus labor.
} 
conditions of existence of the opposition to exploitation, it may be that these progressive non-class economic measures serve only to make acquiescence to capitalist exploitation more palatable to the exploited. Under certain conditions, capitalist exploitation may in fact be intensified despite progress made enhancing wages, improving the distribution of property or power, or facilitating state economic intervention in pursuit of various redistributive measures.

Despite the possibility that non-class economic transformation may be complicit with the perpetuation of class exploitation, this is not a necessity. Since a variety of nonclass economic characteristics form the conditions of existence for capitalist exploitation, Marxian class analysis is open to the possibility that an alliance among advocates of class and non-class economic transformation may have mutually beneficial implications. A persuasive case may be made that those who would oppose poverty, inequality, business cycles, and a host of other contemptible economic characteristics might be well served by considering the contextually specific ways in which capitalist exploitation contributes to these travesties. The parallel case can be made that the opposition of class exploitation may be furthered in specific instances by interventions that affect non-class economic (and other) characteristics that have helped to perpetuate class exploitation. Thus the possibility exists for an alliance between class analytic Marxists and other radicals concerned with non-class economic change. 
The second way in which Marxian class analysis differs from Keynesian economic theory is in its overdeterminist theory of causation. Overdetermination understands all aspects of a totality as mutual constitutive. Since all parts of a totality both shape and are shaped by each other, any change in a part has repercussions for all other parts, and these consequences reflect back to impact the initial change. As a dialectical theory, overdetermination views every part as existing in a contradictory relationship with each other. The stabilizing and destabilizing dynamics among all parts of the totality produce a contradictory unity in constant motion as these complex dynamics among all of the parts provoke a ceaseless process of interactive effects. The overdeterminist use of the term "contradiction" differs from many non-overdeterminist usages of that term. Frequently the depiction of an intervention as "contradictory" is intended as a rebuke, comparable to depicting that action as flawed or logically inconsistent. This suggests that some preferable course of action could be adopted that would be absent of contradiction. From an overdeterminist perspective the term "contradiction" has no pejorative connotation. Any policy intervention (or other economic event) is necessarily contradictory, in that adherence to a mutually constitutive theory of causation implies that any course of action will both promote and detract from its stated objective. Thus there is no possibility of crafting some course of action that is not subject to the negative moment of the dialectic.

The ceaseless process of mutual constitutivity depicted by overdetermination precludes the possibility of stasis, thus overdeterminist economic theory rejects any attempt to stabilize an economy (or any other totality). Instability is not regarded as the 
unfortunate result of a defect in one (or several) of the totality's parts; overdetermination regards instability is the inherent characteristic of any unity in contradiction. Since everything is always unstable, the possibility of identifying and correcting the "causes" of instability is contrary to the logic of overdetermination. Remedial action intended to ameliorate one source of instability will have unintended consequences on all other aspects of the mutually constitutive totality of economic relations in a capitalist class process. In turn, these ramifications will reflect back upon the source of instability that the original intervention sought to correct. Thus even a "successful" intervention will have unintended consequences that both enhance and undermine the intended outcome of that intervention.

This overdeterminist perspective diverges from the Keynesian theory in its rejection of the pursuit of economic stability via policies intended to stabilize aggregate demand. Because Marxism shares Keynesianism's rejection of Say's law in a non-barter economy, there are considerable points of similarity between the Keynesian analysis of insufficient aggregate demand and the Marxian analysis of realization crises. However, overdeterminist Marxism regards the realization crisis as only one of multiple crises that may afflict the capitalist class process. From an overdeterminist perspective, it is misleading to elevate one crises tendency as the singular or most important form of crisis. It may be that at a given historical juncture a realization crisis develops, but any attenuation of this crisis tendency does not produce a capitalism free of contradiction. The attenuation of a realization crisis may exacerbate other crisis tendencies. For this reason, overdeterminist Marxism insists on seeing the interaction among multiple causes 
of instability. This is not to say that a program for economic change informed by overdeterminism may not include policies that are consistent with the Keynesian attempt to stimulate aggregate demand. However, from an overdeterminist perspective, this intervention could not be perceived as creating economic stability, but would instead be a strategy to advance a program for economic transformation that is cognizant of its inevitable role in unleashing forces that will have both stabilizing and destabilizing implications.

\section{The Contradictory Implications Of "Finance As Servant": The Class Analytics Of The} Subsumed Class Struggle Between Productive And Financial Capital

Using the perspective of overdeterminist Marxism, this dissertation presents a critical reflection on the Keynesian motivations of the New Deal financial reform agenda. In doing so, Marxian class analysis of financial capital is extended to a variety of issues concerning financial intermediation. In Marxian class analytic categories, financial intermediaries are understood as financial capitalist firms. Financial capitalist firms engage in the process of financial intermediation in order to gather together funds and expand value by advancing these funds to productive capitalist firms (in return for a subsumed class revenue), and other capitalist firms, individuals and other entities (in return for a non-class revenue). ${ }^{16}$ The saver provides the savings to financial intermediaries in hopes of both preserving their principal and earning some rate of return.

\footnotetext{
${ }^{16}$ In addition to this subsumed class activity and non-class revenue in the form of interest payments and dividends, the second chapter expands on some additional non-class dimensions of financial capitalist activity.
} 
Thus the financial capitalist is also frequently (although not always) obliged to pay some form of return to the saver for access to the funds with which the financial capitalist earns subsumed class and non-class revenues.

In order to examine the Keynesian agenda for financial reform, the dissertation will focus on the subsumed class role of financial capital and the subsumed class struggles that animate this role. However, it is important to acknowledge that these subsumed class issues are overdetermined. Chapter two, for example, will consider the non-class value expansion pursued by financial capital as one overdeterminant of subsumed class role of financial capital. Another overdeterminant of financial capitalist activity that will play a recurring role throughout the dissertation concerns the risks inherent in financial intermediation. It is always possible that the saver will not receive a rate of return on their savings, or they may lose their initial savings entirely, because of various difficulties that may arise in the process of financial intermediation. Thus financial capitalist activity is constantly overdetermined by struggles concerning the extent to which the financial intermediary (or intermediaries), the saver, the user of the funds or some fourth party (i.e. the state) will bear this risks.

The Keynesian agenda that finance should be the servant of production can be restated in class analytic terms by referring to the Marxian analysis of the subsumed class relationship between productive and financial capital concerning the provision of money capital to the capitalist fundamental class process. One of the ways that financial capital can facilitate accumulation is via the provision of money capital to productive capital in 
return for a low subsumed class payment. ${ }^{17}$ This subsumed class payment is determined, in part, in the process of subsumed class struggle between productive and financial capital. Thus, to the extent that capitalist accumulation is assisted by low subsumed class payments for access to money capital, the Keynesian desire that finance should be the servant of production can be reinterpreted in Marxian class analytic terms as the desire to favor productive capital in its subsumed class struggle with financial capital. In this light, the financial reforms ushered in by the New Deal are seen as an attempt to intervene in the subsumed class struggle between productive and financial capital in order to support the ability of productive capital to access money capital cheaply.

To foreshadow the contradictions that afflicted the Keynesian agenda for financial reform, we consider the difficulties implied in the attempt to oblige financial capital to provide money capital to the capitalist fundamental class process in return for a low subsumed class payment. Despite the desirability of this outcome from a Keynesian proaccumulation perspective, this situation poses a problem for financial capitalist firms. As unproductive capitalists, financial capitalists are motivated to fulfill their subsumed class role in the attempt to expand value. Downward pressure on the subsumed class revenue received in return for the provision of a given amount of money capital reduces the incentive of financial capitalists to pursue profits by fulfilling this subsumed class role, and, as we shall discuss in chapter two, they may find other uses for the funds at their disposal. Ironically, low subsumed class payments for access to money capital may jeopardize accumulation, in the sense that this situation squeezes the profitability of

\footnotetext{
${ }^{17}$ A low subsumed class payment for access to money capital means that a given subsumed class distribution to financial capitalists secures more money capital and thereby enables increased accumulation.
} 
financial capitalist firms, and in response financial capitalists may reduce their provision of money capital to fund further accumulation. ${ }^{18}$ Thus Keynesian financial reforms werc compelled to balance the desire to promote accumulation with the possibility that the success of this goal might inadvertently undermine accumulation by causing financial capitalist firms to rebel from their subsumed class role.

As a result of this contradiction in the Keynesian agenda for accumulation, the architects of New Deal financial reform legislation were obliged to address a seemingly unmanageable dilemma. They sought to pursue a pro-accumulation agenda which was potentially injurious to the profitability of financial capital, yet they were obliged to intervene to insure that financial capitalist firms were sufficiently profitable that they would fulfill their subsumed class responsibilities in a manner consistent with vigorous accumulation. To make matters worse, they were attempting to manage these divergent imperatives at a time of profound crisis for both productive and financial capital. During the great depression, financial capital was experiencing a devastating crisis of profitability that threatened to slow financial intermediation to a glacial pace. Unless financial capitalist firms (in particular commercial banks, as will be argued below) could be returned to profitability, they would be unable to fulfill their subsumed class responsibilities of channeling money capital to the capitalist fundamental class process, and the prospects for renewed accumulation would be further compromised. Thus the

\footnotetext{
${ }^{18}$ Other factors as well contribute to the profitability of financial capitalist firms. For example, low subsumed class revenues (per unit of money capital advanced) might be consistent with higher profits for financial capitalist firms if the volume of money capital advanced increases. This argument leaves this possibility aside to concentrate on the downward pressure on the profitability of financial capitalist firms when the subsumed class payment required to secure access to a given amount of money capital is reduced.
} 
architects of Keynesian financial reform were obliged to introduce a pastiche of regulatory provisions that attempted to both compromise the profitability of financial capital (by supporting the ability of productive capital to access money capital cheaply) while attempting to protect the profitability of financial capital.

\section{The Subsumed Class Struggle Among Financial Capitalist Firms: New Deal Financial Reforms From The Perspective Of Commercial Banks}

In their desire to make financial capital the servant of productive capital, Keynesian financial reformers contended with a second form of subsumed class struggle. The subsumed class struggle between productive and financial capital is overdetermined by the subsumed class struggle among financial capitalists. Subsumed class struggle among financial capitalists over the division of that portion of surplus value allocated to securing money capital puts downward pressure on the subsumed class payment required to secure money capital. Thus this form of competition among financial capitalists firms is in some ways supportive of the Keynesian agenda to promote accumulation. However, this same competition may also squeeze the profitability of financial capitalist firms, thus overdetermining the contradiction of financial capitalist profitability discussed above. For these reasons, Keynesian financial reforms grappled with a complex and contradictory set of goals vis à vis subsumed class struggle among financial capitalist firms.

The dissertation will consider how the New Deal financial reforms conferred both advantages and disadvantages among different types of financial capitalist firms in an attempt to manage the diverse requirements of the Keynesian reform agenda vis $\grave{a}$ vis financial capital. The emergence of pax financus was enabled, in part, because of the 
remarkable dexterity with which the New Deal financial reforms managed these complex and sometimes entropic imperatives. However, the contradictions inherent in this financial regulatory framework also contributed to the subversion of these financial reforms. To explore how these contradictions ultimately thwarted the intentions Keynesian financial reform, we pay particular attention to the evolution of subsumed class struggles involving financial capital over time. As the overdetermined context changed, this differential regulatory treatment of financial capitalist firms shaped the evolution of subsumed class struggles among financial capitalist firms. As these subsumed class struggles among financial capitalist firms unfolded, this in turn reshaped the subsumed class relationship between productive and financial capital. These changes in both types of subsumed class struggles involving financial capital contributed to undermining the New Deal financial reforms that supported Keynesian welfare state capitalism.

The dissertation explores these contradictions in the New Deal financial reform from the perspective of commercial banks. While commercial banks are only one among several types of financial capitalist firms (including investment banks, pension funds insurance companies and so on), for a variety of historically and institutionally specific reasons commercial banks were a prominent concern for New Dealers. Commercial banks they are the oldest (Roussakis 1997,3$)^{19}$ and arguably the most prominent type of US financial capitalist firm. At the beginning of the New Deal era, the total financial assets held by commercial banks dwarfed those held by any other financial capitalist

\footnotetext{
${ }^{19}$ However banking functions were performed prior to this by colonizing companies, merchants and colonial governments that were engaged in the provision of credit. (see Hammond 1941, 5)
} 
firm, and this dominance continued until 1991 when the total financial assets of both private and government pension funds surpassed those of commercial banks. In addition to their role in the provision of debt capital and other lending, commercial banks are unique among financial capitalist firms for other institutional characteristics (as a prominent Federal Reserve official has famously quipped, commercial banks are "special" $" 20$ ). It has evolved historically that commercial banks play an important role in the payments system whereby transactions are cleared, and via their lending activities they act as the transmission mechanism for monetary policy. Because of their many important roles in the US economy, the Federal Reserve System has been organized to support and oversee commercial banking, and to provide the commercial banking system with unique forms of assistance, including lender of last resort support.

In addition to these unique characteristics of commercial banks, New Deal financial regulation was obliged to focus on commercial banks because of the acute crisis they faced in the early 1930s. Between 1930 and 1933, about a third of US commercial banks failed or were forced into distressed mergers. One conventional measure of commercial bank profitability, the return on assets $(\mathrm{ROA})^{21}$, depicted in Figure 14, chapter 5, stood at about negative .77 percent in 1934 for FDIC member commercial banks who had survived the waves of bank failures. This profound crisis in the

\footnotetext{
${ }^{20}$ The argument that banks are unique among financial capitalist firms is articulated most famously from a non-Marxian perspective by E. Gerald Corrigan in his "Are Bank's Special?". (1982)

${ }^{21}$ The return on assets is measured as the net income divided by total assets.
} 
commercial banking system compromised its ability to act as a provider of loans ${ }^{22}$, its ability to execute transactions, and its effectiveness channel for the transmission of monetary policy. ${ }^{23}$ The situation had reached such urgent proportions that immediately upon assuming office the Roosevelt administration was compelled to announce a national bank holiday to contain the banking crisis. In order that commercial banks could resume their vital role as financial intermediaries, as well as resume their role in the payments system and act as an agent for the transmission of monetary policy, it was an urgent priority for the architects of the New Deal to stem the crisis in the commercial banking system.

As we shall argue below, the resolution of the crisis in commercial banking required that New Deal financial reforms support the profitability of commercial banks. Yet the Keynesian pro-accumulation agenda, which entails low subsumed class payment for access to money capital, implied a further squeeze on commercial bank profitability. Thus the architects of New Deal financial reform were obliged to restore commercial bank profitability while at the same time attempting to avoid exerting upward pressure on subsumed class payment made to acquire debt capital. In their attempt to reconcile these

\footnotetext{
${ }^{22}$ In 1929 , commercial banks held $\$ 36.1$ billion in loans, which constituted $57.9 \%$ of their total assets. By 1934 , total loans held by commercial banks had dropped to $\$ 15.7$ billion, or $34.9 \%$ of total commercial bank assets. (Friedman and Schwartz 1963, 450)

${ }^{23}$ The Federal Reserve was unable to increase the money supply despite increments to high poweredmoney because of the disarray of the commercial banking system. Friedman and Schwartz estimate that the increase in the amount of high powered money made available to the commercial banking system should have produced a rise in the stock of money of $17.5 \%$ in the absence of a commercial banking crisis. (1963, 332-333) However, the crisis in the commercial banking system reduced the money stock by one third despite this increase in high powered-money. (352)
} 
potentially divergent imperatives, Keynesian financial reforms contained contradictory provisions that supported commercial bank profitability in some respects and impeded it in others.

Given the delicate task facing New Deal financial reforms, they achieved considerable success to the extent they supported several decades of relative economic growth and stability while also presiding over a period of high commercial bank profits and low numbers of bank failures. However, as time passed the reforms that had helped to create this fortuitous situation were increasingly blamed for the return of commercial bank profitability problems and a renewed occurrence of commercial bank failures (albeit on a smaller scale that those of the 1930s). In response to this crisis, commercial banks increasingly engaged in activities that undermined the New Deal financial reforms that had been originally designed to enhance their profitability.

The dissertation is organized as eight chapters. In addition to the introduction (chapter one) and the conclusion (chapter eight) the dissertation can be viewed in three major sections, each of which is composed of two chapters. The first set of two chapters (chapters two and three) are devoted to class analytic concerns. They consider the general analysis of the subsumed class struggle involving financial capital, and the specific class analysis of the commercial bank. The second set of two chapters (chapters four and five) present a class analytic account of the New Deal financial reforms. Chapter four presents issues concerning financial capital that emerged prior to the great depression, while chapter five details the New Deal response to those issues. The final set of two chapters 
(chapters six and seven) consider the subsumed class struggle among financial capitalist firms that provoked the unravcling of the Ncw Deal financial reforms toward the later phases of Keyncsian wclfare statc capitalism. Chapter six presents the competitive response of non-bank financial capitalist firms to the restrictions contained in New Deal financial reforms, while chapter seven details the response of the commercial banks to these competitive threats. Chapter eight concludes with some comments conccrning somc of the contributions offered by an overdeterminist and class analytic treatment of the economic history of New Deal financial reforms. 


\section{CHAPTER 2}

\section{A CLASS ANALYSIS OF FINANCIAL CAPITAL: \\ AN INITIAL LOOK AT THE CONTRADICTIONS OF THE KEYNESIAN \\ FINANCIAL REFORM AGENDA}

\section{Introduction}

As chapter one argued, the Keynesian agenda for financial reform was motivated to encourage financial capital to act as a "servant " to productive capital by providing access to money capital in return for a low subsumed class payment. Chapter two elaborates on the overdeterminist class analytic framework that will be used in subsequent chapters to analyze the New Deal regulatory intervention designed accomplish this goal. In order to discern what sort of conditions might promote a low subsumed class payment for access to money capital, the current chapter focuses on the subsumed class struggles involving financial capital. The subsumed class payment required to obtain money capital is shaped by both the subsumed class struggle between productive and financial capital and subsumed class struggles among financial capitalists. By developing the class analytic tools with which to analyze these subsumed class struggles involving financial capital, this chapter begins to outline some of the complexities confronted by the New Deal financial reforms in their attempt to compel financial capital to act as servant to productive capital. 
The chapter begins by analyzing the subsumed class struggle between productive and financial capital over the payment made to secure money capital. The second section of the chapter explores subsumed class struggles among financial capitalists in order to examine the ways in which this type of subsumed class struggle overdetermines the subsumed class struggle between productive and financial capital. Following this, the process of financial intermediation is examined in more detail in order to develop a generic class analytic equation for a financial capitalist firm. This class analytic equation highlights the diverse effects of the various forms of competition among financial capitalist firms on the Keynesian agenda for low subsumed class payments for money capital. The forth section expands the initial class analytic equation for a financial capitalist firm to consider the possibility that financial capital may expand value via the receipt of non-class revenue as well as subsumed class revenue. This facilitates the analysis of how these non-class roles of financial capitalist firms may overdetermine the subsumed class struggles involving financial capital.

Subsumed Class Struggles Between Productive And Financial Capital: A Preliminary View Of The Contradictions Of Keynesian Agenda For Financial Reform

In order to set production in motion, a productive capitalist firm requires money capital. Money capital is value in money form that is used to expand value. When a productive capitalist firm employs money capital to initiate production, it does so in the hopes of expanding value via the appropriation of surplus value at the conclusion of the production process. Although it is possible that a productive capitalist firm has sufficient money capital internally to initiate production, we shall assume that the productive 
capitalist firm requires access to external sources of money capital.' A financial capitalist firm may step in to supply the money capital needed by a productive capitalist firm to set the circuit of productive capital in motion. ${ }^{2}$ We further assume that productive capitalist firms employ all inflows of funds received from financial capitalist firms as money capital to initiate production. ${ }^{3}$ By supplying money capital used to initiate production, financial capitalist firms are engaged in a subsumed class process since they help to secure one of the conditions of existence of productive capital.

In keeping with our focus on the provision of money capital to the capitalist fundamental class process, a financial capitalist firm is initially defined as an unproductive capitalist firm that provides money capital to productive capitalist firms. ${ }^{4}$ In return for the provision of money capital, it is assumed that the financial capitalist firm receives a distribution from the surplus value appropriated by the productive capitalist firm (referred to as a subsumed class revenue). ${ }^{5}$ The financial capitalist firm initially

\footnotetext{
${ }^{1}$ To the extent that productive capitalist firms can generate funds internally to expand the production process, they will be less reliant on money capital supplied by financial capitalist firms. This greater autonomy will in turn overdetermine the subsumed class struggle between productive and financial capital.

${ }^{2}$ Money capital might be provided to productive capitalist firms by entities that are not ordinarily thought of as financial capitalist firms. These entities, such as the state, individuals, or participants in non-capitalist class processes, could provide money capital directly to productive capitalist firms without the intermediating presence of a financial capitalist firm. To simplify the analysis, we assume that money capital is forthcoming to the capitalist fundamental class process only via the financial intermediation of a financial capitalist firm.

${ }^{3}$ However, the possibility exists that a productive capitalist firm might obtain funds from a financial capitalist firm and use them for other purposes.

${ }^{4}$ The definition of a financial capitalist firm is enlarged later in the chapter to consider some of the nonclass means by which a financial capitalist firm might expand value.

${ }^{5}$ There are circumstances in which financial capitalist firms may provide money capital to productive capitalist firms without receiving a distribution of surplus value in return. At present, this possibility is excluded, but it will be considered in the discussion of equity capital below.
} 
begins with some quantity of value $(\mathrm{M})$, which is advanced to surplus value appropriating firms, and later the financial capitalist firm expands value (to $M^{\prime}$ ) as a result of the receipt of the subsumed class revenue. The financial capitalist firm has expanded value, therefore it meets the Marxian definition of a capitalist firm. However, the financial capitalist firm has expanded value in a manner other than the appropriation of surplus value, thus the financial capitalist firm is referred to as an unproductive capitalist firm.

In the third volume of Capital, Marx points out that the size of this subsumed class payment made by productive capital to financial capital to secure access to money capital is indeterminate. ${ }^{6}$ The size of the subsumed class payment for access to money capital is overdetermined by a large variety of political, cultural, natural and economic processes. These political and cultural processes can include domestic and international legal and regulatory constraints, electoral pressures, the historically specific evolution of institutional structures, as well as religious beliefs and psychological and emotional proclivities concerning risk and liquidity preference. Numerous economic factors, such as the impact of the business cycle, the pace of technological change and the level of indebtedness of productive capitalist firms also exert diverse influences on the payment required to secure money capital.

All of these overdeterminants shape the struggle between productive and financial capitalist firms to determine the size of the subsumed class payment. Because this struggle concerns the distribution of appropriated surplus value, it is referred to as a

\footnotetext{
${ }^{6}$ Marx explains that the maximum subsumed class payment would be the entire "profit"(surplus value) itself, while minimum limit is "altogether indeterminable". $(1967,358)$
} 
subsumed class struggle. ${ }^{7}$ This struggle is antagonistic, in that productive capital seeks to minimize the required distribution of surplus value, while financial capital seeks to maximize it. However, the relationship between productive and financial capital is animated by cooperation as well as conflict. Productive capitalist firms rely on providers of money capital, given that (under current assumptions) the productive capitalist firm requires access to external money capital as a condition of its existence. Financial capitalist firms also rely on productive capitalist firms, given that (under current assumptions) financial capitalist firms expand value by receiving a distribution of the surplus value appropriated by the productive capitalist firm. ${ }^{8}$ This mutual dependence between productive and financial capitalist firms confers a cooperative dimension on their relationship. ${ }^{9}$ Thus the subsumed class struggle between financial capitalist firms and productive capitalist firms is a contradictory dynamic shaped by both antagonism and cooperation.

In light of our analysis of the subsumed class struggle between financial and productive capital, the Keynesian agenda vis à vis financial capital can be reexamined from a class analytic perspective. As was mentioned in chapter one, the Keynesian

\footnotetext{
${ }^{7}$ In addition to the struggles over the size of the subsumed class payment, productive and financial capital are also engaged in struggles over other dimensions of their relationship, such as conflict over the terms under which money capital is provided (these may include struggles over what information is to be disclosed by either party in the course of negotiating the transaction, the legal recourses if one party fails to fulfil its contractual obligations, and questions of conditions that may be attached to the procurement of money capital and so on).

${ }^{8}$ Further on in the chapter we will introduce non-class avenues through which financial capitalist firms expand value.

${ }^{9}$ Thus their antagonistic struggle over the size of the subsumed class payment made to secure money capital is tempered because neither party wants to dramatically undermine the conditions of existence of the other, for to do so would jeopardize their own conditions of existence.
} 
agenda to compel financial capital to act as the "servant" of productive capital can be interpreted as the attempt to encourage a subsumed class relationship between financial and productive capital that promotes a low subsumed class payment for access to money capital. However, the success of this Keynesian agenda is potentially injurious to financial capitalist firms qua capitalist firms. As unproductive capitalists, financial capitalist firms are motivated to fulfill their subsumed class role in the attempt to expand value via the receipt of subsumed class revenues. Downward pressure on their subsumed class revenue reduces the incentive of financial capitalist firms to fulfill this subsumed class role. Financial capitalist firms finding their subsumed class revenue squeezed may cease engaging in financial capitalist activity, or they may respond by refraining from advancing money capital to the capitalist fundamental class process and find other uses for the funds at their disposal (for example, they may engage in financial capitalist activities that earn non-class revenues, as is discussed below).

Thus the Keynesian agenda to compel financial capital to act as the servant to productive capital by providing money capital to the capitalist fundamental class process in return for a low subsumed class payment for access to money capital ivrestles with the following contradiction. A low subsumed class payment for access to money capital supports accumulation by making inflows of money capital less expensive to obtain. Yet ironically, low subsumed class payments for access to money capital may jeopardize accumulation, in the sense that this situation squeezes the profitability of financial capitalist firms. In response financial capitalist firms may reduce their provision of money capital to fund further accumulation. Since this contradiction between the 
Keynesian agenda to lower the subsumed class payment for access to money capital and financial capitalist profitability will be the focus of much of attention in the dissertation, it merits a way of referring to it succinctly. It will be referred to in the remainder of the dissertation as the "master/servant contradiction" of the Keynesian agenda. This terminology acknowledges its debt to Hegel's master/slave dialectic, as the present analysis seeks to reflect the Hegelian insight that the act of compelling the servitude of one entity entails setting in motion negation of that servitude.

This master/servant contradiction of the Keynesian agenda varies dramatically in its implications depending on the overdetermined context. The degree to which the reduction in the subsumed class payment for money capital detracts from financial capitalist profitability varies according to a host of factors that shape the demand and supply of money capital. It may be that the payment for access to a given amount of money capital decreases, but productive capitalist firms foreseeing vigorous demand for their output increase the total amount of money capital demanded. In this event, it may be possible that the total value inflow received by the financial capitalist firm increases. This would be a situation in which the success of the Keynesian accumulation agenda (and its stimulation in the demand for money capital) alleviates the pressure on financial capitalist profitability. Moreover, the response of financial capitalist firms to pressure on their profitability will be shaped by the options open to them. If there are many alternative ways of earning revenues apart from the receipt of subsumed class revenue for the provision of money capital, then there is greater potential that financial capital will rebel from their "servant" status to pursue value expansion by other means. 
The master/servant contradiction of the Keynesian financial agenda implied complex challenges for the development of New Deal financial reforms. New Deal financial reforms attempted to privilege productive capital in its subsumed class struggle with financial capital, while at the same time ensuring that financial capitalist profitability was not impaired to the extent that it might provoke responses on the part of financial capital that might sabotage the Keynesian agenda. At some junctures the New Deal regulatory framework dealt startling blows to the profitability of financial capital, while other regulatory provisions attempted to insulate financial capital from the ramifications of these blows. However, the coherence of these diverse regulatory interventions can be discerned by appreciating the contradictory imperatives that animated Keynesian financial reform. What may appear as irreconcilable inconsistencies in Keynesian financial regulation are the consequences, in part, of the struggle among the conflicting imperatives of the Keynesian financial reform agenda.

\section{The Keynesian Financial Reform Agenda} And The Question Of Competition Among Financial Capitalist Firms

One overdeterminant of the subsumed class payment for access to money capital is the competitive struggles among financial capitalist firms. Given assumptions made thus far in the analysis, each financial capitalist firm is reliant on subsumed class revenue to expand value, thus each financial capitalist firm must compete with all other financial capitalist firms to maximize their share of the distributions of surplus value allocated by productive capitalist firms for securing access to money capital. Because this competitive 
struggle among financial capitalist firms concerns distributions of surplus value, it is also referred to as a subsumed class struggle. This subsumed class struggle among financial capitalist firms is in turn overdetermined by a great variety of factors, such as the number and relative size of financial capitalist firms, the existence (or not) of barriers to the mobility of money capital ${ }^{10}$ and so on. Like all subsumed class struggles, the subsumed class struggle among financial capitalist firms is animated by contradictory impulses. It is an antagonistic struggle, in that financial capitalist firms compete with one another over the division of that portion of surplus value that is allocated to securing access to money capital. However, the subsumed class struggle among financial capitalist firms is animated by cooperation as well as conflict. Financial capitalist firms are allied in their wish to maximize the amount of surplus value that productive capitalist firms are obliged to earmark for securing access to money capital generally. To some extent, they may cooperate in attempting to enhance the political, cultural, natural and economic conditions that enhance the importance of (and payment made to secure access to) externally provided money capital. ${ }^{11}$

From the perspective of Keynesian agenda for financial capital, the competitive dimension of subsumed class struggle among financial capitalist firms supports the Keynesian agenda of a low subsumed class payment for access to money capital. As

\footnotetext{
${ }^{10}$ Barriers to capital mobility, such as legal or regulatory obstacles to the movement of funds across national or sub-national borders, will shape the degree to which financial capitalist firms of a given jurisdiction face competition from financial capitalist firms of other jurisdictions.

${ }^{11}$ However, as providers of a subsumed class process, financial capitalist firms are constrained by their dependence on productive capital. If financial capital is so successful in enhancing the subsumed class payment made to secure money capital that the ability of productive capital to secure its other conditions of existence are compromised, financial capital will have unintentionally undermined their own conditions of existence.
} 
financial capitalist firms compete in the process of providing money capital to the capitalist fundamental class process, this competition exerts downward pressure on the subsumed class payment required to secure access to money capital. Thus the Keynesian agenda of promoting low subsumed class payments for access to money capital is consistent with a policy of intensifying this subsumed class struggle among financial capitalist firms. However, to the extent that subsumed class struggle among financial capitalist firms puts downward pressure on this subsumed class payment, it may also exacerbate the previously mentioned master/servant contradiction of the Keynesian agenda. Vigorous subsumed class struggle among financial capitalist firms that reduces the subsumed class payment required to secure money capital may undermine financial capitalist profitability to the extent that financial capitalists rebel from this subsumed class role, which in turn may jeopardize access to funds to support accumulation.

While subsumed class struggle among financial capitalist firms is supportive of a lower subsumed class payment for access to money capital, the same cannot be said for all competitive struggles among financial capitalist firms. In order to discern these various and opposing implications of competition among financial capitalist firms, the class analysis of financial capitalist firms must be developed in more detail. Thus far financial capitalist firms have been analyzed in terms of their expansion of value by providing money capital to productive capitalist firms. However, the question of where the financial capitalist secures the funds which are used to earn subsumed class revenues must now be addressed. While it is possible that financial capitalist firms use their own funds for this purpose, in general financial capitalist firms secure their initial money 
capital via the process of financial intermediation. As financial intermediaries, financial capitalist firms gather together the savings in the economy, and these amassed savings constitute the initial money capital that financial capitalists use to expand value (under present assumptions, via the receipt of subsumed class revenues).

Financial intermediation can be analyzed by breaking this process into two interrelated phases: the gathering together of savings to form the money capital at the disposal of the financial capitalist firms, and the provision of this money capital to productive capitalist firms in order to secure subsumed class revenue. ${ }^{12}$ To illustrate these two moments of financial intermediation, the "generic" 13 class analysis of a financial capitalist firm is depicted in Figure 1 below. The first moment of financial intermediation consists of accessing savings in the economy in the form of non-class revenues. ${ }^{14}$

Associated with this non-class revenue is typically some sort of $\mathrm{Y}$ expense, as the savers in the economy are usually compensated for the provision of their savings by some form of return (such as the interest paid funds deposited in a savings account). ${ }^{15}$ In addition,

\footnotetext{
${ }^{12}$ In non-Marxian parlance, this is first phase is often referred to as the "sources of funds" while the second phase is described as the "uses of funds".

${ }^{13}$ It is referred to as "generic" because, at this stage, we are not explicit about the particular way in which the financial capitalist firm gathers savings or the way in which the financial capitalist firm provides these savings to productive capitalist firms.

${ }^{14}$ If the initial savers chose to withdraw their savings from the financial capitalist firm, this would be reflected as a reduction in this non-class revenue. If savings withdrawn from a financial capitalist firm exceeded the inflow of new funds, this non-class revenue would become negative.

${ }^{15}$ Below we extend the class analysis of financial capital to consider the possibility that capital gains (a non-class revenue) may compensate the provider of money capital to the extent that the subsumed class payment for access to money capital is reduced to zero.
} 
non-class revenues may be generated if a recipient of money capital repays this money capital to the financial capitalist firm, and these funds are then available to support new advances of money capital to productive capitalists.

The second moment of financial intermediation is distinguished by a variety of other expenses and revenues associated with the disbursement of savings to productive capitalist firms and the subsequent earning of subsumed class revenue. An X expense is incurred when the financial capitalist firm advances money capital to the productive capitalist firm, and the financial capitalist firm has expanded value when it receives subsumed class revenue as payment for the use of the money capital. Further X expenses include the costs associated with research, monitoring and collection that accompanies the receipt of subsumed class revenue. Additional expenses include all of the costs associated with the operation of a financial capitalist firm, such as occupancy costs, salaries and so on that may be difficult to categorize as $\mathrm{X}$ or $\mathrm{Y}$ expenses. ${ }^{16}$ For simplicity, it is assumed that costs that are debatable in this respect, and all remaining costs, are $\mathrm{Y}$ expenses.

Figure 1: Value Inflows and Expenditures of a Generic Financial Capitalist Firm

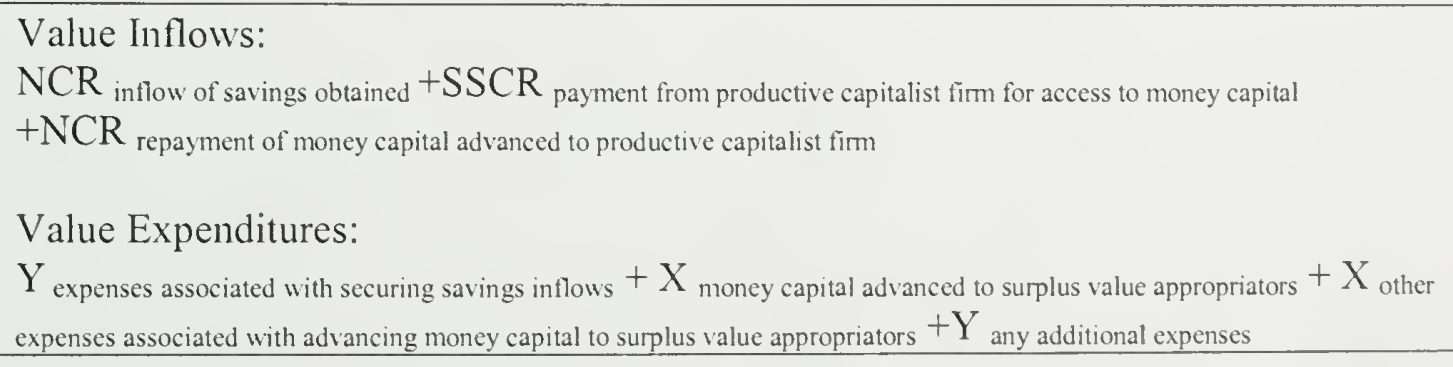

\footnotetext{
${ }^{16}$ For example the salary of a bank employee may be partially an $\mathrm{X}$ expense (to the extent that this employee in involved in securing the receipt of subsumed class revenue) and partly a $Y$ expense (to the extent that this employee is involved in securing deposits for the bank).
} 
In the first moment of financial intermediation, all financial capitalist firms are engaged in a competitive struggle with one another in order to maximize the funds they can attract from savers, while seeking to minimize the $Y$ expenses associated with attracting savings. To refine the analysis of competition among financial capitalist firms in the first moment of financial intermediation, financial capitalist firms are often grouped according to the avenues through which they typically access the savings of an economy. For example, depository institutions such as commercial banks are distinguished because they secure funds by accepting deposits, while pension fund companies collect funds via pension fund contributions, and insurance companies receive funds via insurance premiums. These groupings of financial capitalist firms according to the manner in which funds are accessed in the first moment of financial intermediation will be referred to below as the "types" or "categories" of financial capitalist firms. Competition among financial capitalist firms occurs both within a particular category, and across categories. In the first moment of financial intermediation, the competition across categories will be animated by the efforts of financial capitalist of each different category to compel savers to hold their savings in the form corresponding to their particular category. This in turn will be shaped by the particular expenses as well as the particular advantages ${ }^{17}$ related to each category, as financial capitalist of each category seek to minimize the expenses and expand the advantages pertaining to their category.

\footnotetext{
${ }^{17}$ For example, savings held in the form of deposits are attractive from a financial capitalist firm's point of view because is relatively easy for savers to open bank accounts and store savings in them, however this ease of access also means that the funds can be withdrawn quickly. It is somewhat more complex for savers to initiate holding their savings in pensions (they may, for example, need to be employees of a certain company to participate in the pension fund). However savings held in pension funds are attractive from the financial capitalist firm's point of view because these savings are often left in place for long periods of time.
} 
Unlike competition among financial capitalist firms in the second moment of financial intermediation, competition among financial capitalist firms in this first moment of financial intermediation is not a subsumed class struggle, in that it is not a struggle concerning distributions from surplus value. ${ }^{18}$ However, competition for access to savings is, of course, a condition of existence for subsumed class struggle in the second moment of financial intermediation. Competition among financial capitalist firms in the first moment of financial intermediation may be contrary to a Keynesian agenda for low subsumed class payment for access to money capital, in that this competition may increase the rate of return that financial capitalist firms are obliged to pay to attract savings. If circumstances permit, financial capitalist firms may pass this cost increase on to productive capitalist firms by increasing the cost of securing money capital. Even if financial capitalist firms are not in a position to pass these increased costs along to productive capitalists via an subsumed class payment required to secure money capital, competition over access to savings may still exacerbate the master/servant contradiction of the Keynesian agenda. If financial capitalist firms absorb these cost increases without any corresponding increase in revenues, this will squeeze the profitability of financial capitalist firms, and this may in turn subvert accumulation.

\footnotetext{
${ }^{18}$ We assume that the savings come from a variety of sources, such as savings from workers' wages, savings from the state's tax collection and other revenue generating activities, and savings from a variety of participants in non-capitalist class processes and unproductive capitalists. However, it may be that savings are the retained earnings of productive capitalist firm, in which case competition among financial capitalist firms for the opportunity to intermediate these savings might arguably be considered a subsumed class struggle. For simplicity we leave this possibility aside.
} 
Competition among financial capitalist firms in the second moment of financial intermediation takes the form of a subsumed class struggle over distributions of surplus value. Each financial capitalist firm would like to maximize the subsumed class revenue that it receives, while minimizing the $X$ expenses associated with earning these subsumed class revenues. This subsumed class form of competition among financial capitalist firms is beneficial to the Keynesian agenda, in that it may exert downward pressure on the costs of securing money capital. However, the benefits of this subsumed class struggle among financial capital vis à vis the size of this subsumed class payment must be viewed in light of the master/servant contradiction, since it is possible that very vigorous subsumed class competition might impair the profitability of financial capitalist firms to the extent that they might take actions that are inconsistent with the Keynesian agenda for financial capital.

In the second moment of financial intermediation, the financial capitalist firm may provide money capital to the productive capitalist firms in one of two forms. The provision of money capital may take the form of a loan, in which case it is referred to as debt capital, or by the initial ${ }^{19}$ purchase of stock, in which case it is referred to as equity capital. $^{20}$ These two forms of money capital are related to the provision of different conditions of existence for the productive capitalist firm, and they carry with them

\footnotetext{
${ }^{19}$ The term "initial" indicates that the stock is purchased directly from the productive capitalist firm, thus the revenues from the sale of the stock can be employed as money capital by the productive capitalist firm. Purchases of stock on the secondary market do not provide revenue for the productive capitalist firm.

${ }^{20}$ To simplify the analysis in its preliminary stages, we will assume in this section that the financial capitalist firm directly provides loans or purchases the stock from the productive capitalist firm. We will relax this assumption below to consider how financial capitalist firms may facilitate access to money capital by arranging loans or the stock purchases by third parties through activities such as securities underwriting.
} 
different implications. Debt capital (the condition of existence of credit) carrics with it the necessity of making subsumed class payment referred to as interest payment, ${ }^{21}$ and the repayment of the principal of the loan. Equity capital (the condition of existence ownership) does not carry with it the necessity of making a subsumed class payment, although firms may choose to pay the subsumed class payment referred to as a dividend. The advance of money capital in equity form does not require repayment, however the receipt of equity capital does entail other obligations (such as the entitlement of stockholders to vote in the election of the board of directors) and opportunities (such as the opportunity for capital gains, as will be discussed below).

One of these forms of subsumed class struggle among financial capitalist firms can be competition between providers of debt and equity capital. Debt and equity capital providers are engaged subsumed class struggle with each other as each attempts to maximize the distribution of surplus value allocated to secure the particular condition of existence that they provide. Because productive capitalist firms have two alternative means through which to secure access to money capital, the productive capitalist firm may benefit from subsumed class struggles among these two types of providers of money capital to reduce the subsumed class payment required to secure access to money capital generally. From the point of view of a productive capitalist firm in need of money capital,

${ }^{21}$ In practice, some providers of debt capital also charge fees in addition to interest. In this event, such fees could be treated as additional subsumed class revenues, if they are fees that the financial capitalist firm is able to compel borrowers to pay in order to have access to money capital. However, it may be argued that such fees could be considered surplus value, as when the fee is paid in return for something (say monthly statements or automatic account debiting) which is arguably a service. It may also be the case that a "fee" is really a component of the interest payment, but it has been presented as two separate payments (perhaps in order to disguise the costs of a loan from a potential borrower). 
debt and equity capital are often close substitutes. Thus the productive capitalist may be able to alter their mix of debt and equity capital to enhance their ability to bargain over the size of the subsumed class payment required to secure access to both types of money capital. Alternatively, providers of both types of money capital may ally in the hopes of enhancing their ability to increase the subsumed class payment that productive capitalist firms must make to secure money capital in either form. In this way, the subsumed class struggles among providers of debt and equity capital overdetermine (and are overdetermined by) subsumed class struggle between productive capitalist firms and providers of money capital.

By analyzing the two distinct moments of financial intermediation we can see the varying effects of competition among financial capitalist firms on the subsumed class payment required to secure money capital. The Keynesian financial reform agenda to promote low subsumed class payment for access to money capital was obliged to deal with these diverse implications of competition among financial capitalist firms. In general, Keynesian financial reform sought to intensify the subsumed class competition among financial capitalist firms in the second moment of financial intermediation, while moderating competition among financial capitalist firms in the first moment of financial intermediation. However, this general orientation of Keynesian financial agenda was subject to the proviso that financial capitalist firms needed to maintain adequate profitability in order that they would behave in a manner consistent with the overall Keynesian financial agenda. As we shall see, this divergent agenda with respect to competition among financial capitalist firms compelled the architects of New Deal 
financial reform to create regulatory interventions that sought to simultaneously encourage competition among financial capitalist firms in some respects, while discouraging it in other respects.

\section{Non-Class Elements Of Financial Capitalist Activity: \\ A Further Overdeterminant Of Subsumed Class Struggles Involving Financial Capital}

Thus far in our analysis we have defined a financial capitalist firm as an unproductive capitalist firm that expands value by providing money capital to productive capitalist firms. In order to proceed further with our analysis of the contradictory imperatives animating Keynesian financial reform, we must extend our class analytic framework to consider some of the ways that financial capitalist firms may expand value in addition to their receipt of subsumed class revenue. These non-class revenues interact with the subsumed class revenues analyzed above to overdetermine the subsumed class struggles involving financial capital. This more complex picture of both the subsumed class struggle between productive and financial capital and the subsumed class struggle among financial capitalist firms illuminates further challenges for the design of Keynesian financial reforms.

We begin with the generic class analytic equation of a financial capitalist firm presented in Figure 1 above. At that point, non-class revenues entered into the class analysis of financial capitalist activity only as inflows of savings gathered in the first moment of financial intermediation, or the repayment of money capital previously advanced to productive capitalist firms. However, financial capitalist firms have other 
ways of earning non-class revenues in the second moment of financial intermediation. To facilitate this discussion, financial capitalist firms that advance funds by means of loans and those that advance funds by means of purchasing equities will be analyzed separately. In this manner, a more specific class analytic equation for both types of financial capitalist firms can be derived by considering the non-class revenues that are relevant to each group. By discerning the impact of non-class revenue on both types of financial capitalist firms, further nuances animating the subsumed class struggle among financial capitalist firms are highlighted.

A financial capitalist firm that lends funds may elect to make loans to entities that are not productive capitalist firms. These entities can include workers or other individuals, unproductive capitalist firms, states or other domestic or international organizations. ${ }^{22}$ When a financial capitalist firm lends funds to one of these entities, the interest income it receives is a non-class revenue. By incorporating the possibility that money-lending financial capitalist firms may advance funds to both productive capitalist firms and other borrowers of funds, we derive a general class analysis of money-lending financial capitalist firms (Figure 2). Now loans advanced may be either $\mathrm{X}$ loans (to surplus value appropriators) or Y loans (to others). The interest income earned on these loans will take the form of a subsumed class revenue (on a loan to surplus value appropriators) or nonclass revenue (on a loan to others), and the expenses associated with earning interest income may be $\mathrm{X}$ or $\mathrm{Y}$ expenses accordingly. The varied costs associated with earning

\footnotetext{
${ }^{22}$ It is also possible that a money-lending financial capitalist firm might make loans to surplus labor appropriators in non-capitalist class process. In that event, the interest income from the loans would not be a non-class revenue, but rather a subsumed class payment from a non-capitalist class process. We leave this possibility aside in the class analytic equations below.
} 
interest income are either $\mathrm{X}$ or $\mathrm{Y}$ expenses, depending on the type of loans advanced, and these costs are depicted in the term " $(\mathrm{X}+\mathrm{Y})$ cxpenses associated with advancing loans". However, the additional dimension of non-class revenues from lending has not directly affected the first moment of financial intermediation, in that the financial capitalist firm still requires nonclass revenue in the form of savings inflows and must bear some $\mathrm{Y}$ costs associated with securing these savings inflows.

Figure 2: Class Analysis Of A Money-Lending Financial Capitalist Firm

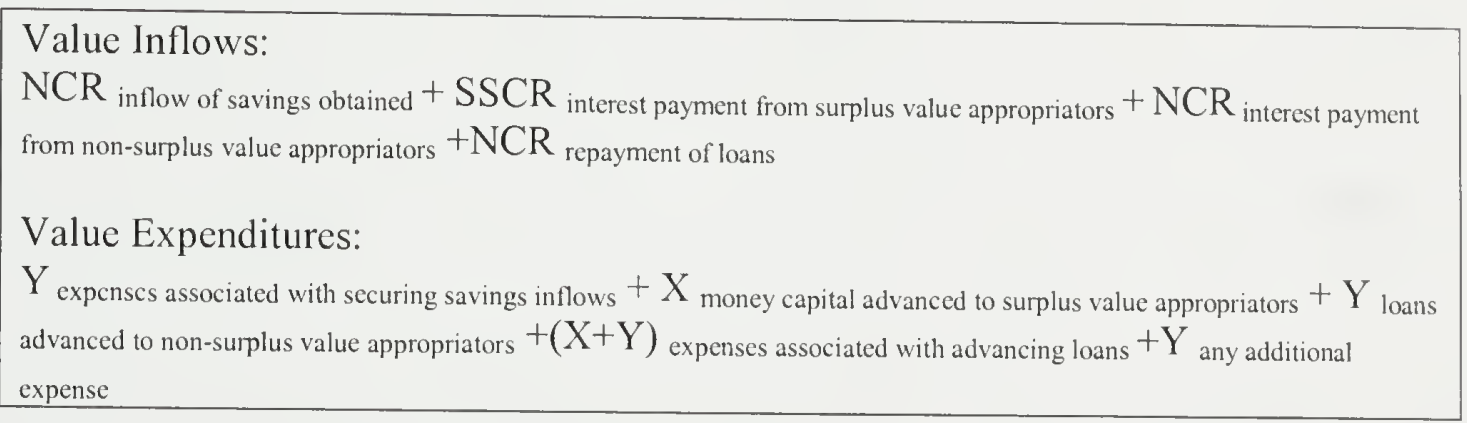

The possibility that a money-lending financial capitalist firm may mix both subsumed class and non-class revenue generation overdetermines the subsumed class struggle between productive and financial capital. Conditions may be such that the subsumed class revenues obtained from supplying money capital to productive capitalist firms are overshadowed by non-class revenues. In this event, the conditions of existence of the financial capitalist firm may become more tenuously related productive capitalist firms' success in securing their conditions of existence. ${ }^{23}$ It is possible that the capacity

${ }^{23}$ However, even a financial capitalist firm which derives its revenues principally through non-class revenues may still be concerned about the wellbeing of productive capitalist firms. A condition of existence of non-class revenue may be the continued prosperity of productive capitalist firms, as occurs when a financial capitalist firm makes loans to workers of productive capitalist firms. 
of the financial capitalist firm to rely on non-class revenues may put it in a better position to demand a higher subsumed class payment in return for the provision of money capital to productive capitalist firms. However, the pursuit of non-class revenue by financial capital may also assist productive capital. The productive capitalist firm has various condition of existence in addition to access to money capital, and a financial capitalist firm's non-class lending may aid in the provision of some of these conditions of existence. For example, the provision of funds to consumers, states and unproductive capitalist firms may ameliorate realization problems for productive capital if these funds are used to buy the commodities produced by productive capitalist firms.

Financial capitalist firms that provide equity capital to productive capital also have the opportunity to earn non-class revenue. We have assumed thus far that providers of equity capital may earn a subsumed class revenue in the form of dividends. However, a financial capitalist firm may also resell their stock on the secondary stock market, and if it is able to resell the stock at a price higher than what was originally paid, the resulting capital gain is a non-class revenue. ${ }^{24} \mathrm{~A}$ class analysis of a financial capitalist firm that provides equity capital is depicted in Figure 3. In the first moment of financial intermediation, a financial capitalist firm that provides equity capital continues to be similar to money lending financial capitalist firms, in that they obtain savings as a nonclass revenue and they incur $\mathrm{Y}$ expenses associated with this. However, now financial capitalist firms that provide equity capital have two ways of expanding value. They may

\footnotetext{
${ }^{24}$ Money-lending financial capitalist firms may also realize capital gains when a debt security, such as a bond, appreciates in price.
} 
receive dividends (a subsumed class revenue that obligates the firm to incur

corresponding $\mathrm{X}$ expenditures) or they may receive capital gains (a non-class revenue

that carries with it corresponding $\mathrm{Y}$ expenses involved with stock market research,

transaction fees etc). The initial purchase of the stock subsequently earns subsumed class

revenues as dividends constitutes an $\mathrm{X}$ expense, since we have assumed throughout that

the stock purchased is issued by a productive capitalist firm. ${ }^{25}$

Figure 3: Class Analysis Of Financial Capitalist Firm That Provides Equity Capital To Productive Capitalist Firms

Value Inflows:

$\mathrm{NCR}$ inflow of savings obtained $+\mathrm{SSCR}$ dividends $+\mathrm{NCR}$ capital gains

Value Expenditure:

$Y$ expenses associated with securing savings inflows $+X_{\text {initial purchases of stock }}+X_{\text {other expenses associated with }}$ purchasing stock $+Y_{\text {expenses associated with sccuring capital gains }}+Y_{\text {any additional expense }}$

The possibility of capital gains also overdetermines the subsumed class struggle between productive and financial capital. This increased diversity of revenue sources increases the flexibility of financial capital. Such a financial capitalist firm may refrain from channeling money capital to productive capitalist firms and elect instead to engage in the pursuit of capital gains by buying and selling stock on secondary markets.

However, productive capital also gains greater flexibility as a result of the possibility of capital gains on stocks. The possibility of capital gains on the sale of equities may enable productive capitalist firms to reduce the subsumed class payments made as dividends in

\footnotetext{
${ }^{25}$ For completeness, it should be acknowledged that financial capitalist firms may advance equity capital to firms that are not productive capitalist firms, as when they buy the stock of other financial capitalist firms, merchant capitalist firms, or firms involved in non-capitalist class processes. These possibilities will be left aside.
} 
order to attract equity capital, since stockholders may be compensated for low dividends by the receipt of capital gains. This possibility in turn shapes the subsumed class struggle between financial capitalist firms and productive capital. In the absence of other overdetermining factors, such as a differences in the tax treatment between debt and equity capital inflows, we assume that debt and equity capital are close substitutes from the point of view of a productive capitalist firm. ${ }^{26}$ Thus to the extent that possibility of capital gains enables productive capitalist firms to reduce the subsumed class payment made in the form of dividends, this situation affords productive capitalist firms the opportunity to intensify subsumed class struggle between the providers of debt and equity capital and thereby put downward pressure on the subsumed class payment made to secure both forms of money capital.

One final complication in the class analysis of a financial capitalist firm concerns the possibility that a firm involved in financial capitalist activity may pursue the expansion of value via the appropriation surplus value. In addition to the financial capitalist activities analyzed above, financial capitalist firms often provide financial advice, record keeping, the safekeeping of securities, automatic bill payment and so on. These activities must be scrutinized to discern whether they might constitute the production of a commodity, and if so the income generated from these activities would be appropriated surplus value. A firm that appropriates surplus value in addition to the financial capitalist activities

\footnotetext{
${ }^{26}$ This principle was articulated in mainstream economic literature by Modigliani and Miller (1958).
} 
previously analyzed would occupy multiple class positions as both a financial capitalist and productive capitalist firm. To make the subsequent analysis more manageable, wc omit surplus value appropriation in the analysis for the remainder of this chapter.

\section{Potential Financial Capitalist Responses To Support Their Profitability In The Face Of The Keynesian Financial Reform Agenda}

Now that we have examined some of the additional ways in which financial capitalist firms can expand value through non-class revenues, we can anticipate some of the potential responses on the part of financial capital to the Keynesian pro-accumulation agenda. If financial capitalist firms experience pressure on their profitability as a consequence of downward pressure on the subsumed class payment required to secure money capital, they may intensify their pursuit of non-class revenues. In some ways this may be supportive of accumulation, as when funds advanced for purposes other than accumulation support demand for the commodities produced by productive capitalist firms. However, the orientation towards non-class revenues may pose a problem for the Keynesian pro-accumulation agenda to the extent that this response may siphon funds away from the provision of money capital the capitalist fundamental class process.

The pursuit of non-class revenues to support financial capitalist profitability can have further implications that may jeopardize the Keynesian accumulation agenda. The non-class revenues pursued by financial capitalists may be predicated on the pursuit of capital gains. This may occur when financial capitalists engage in the direct pursuit of capital gains in the secondary markets for securities, or this may occur less directly, as 
when financial capitalists engage in money-lending designed to support the purchase of securities on secondary markets for the purpose of securing capital gains. From the point of view of Keynesian theory, this increased orientation of financial capitalists to the pursuit of capital gains may have negative consequences for the stable and vigorous accumulation that Keynesians wish to promote.

Switching briefly into Keynesian terminology, the Keynesian analysis of the volatility of investment spending is informed by the concept of "fundamental uncertainty". Keynes argues that investors must commit to long-term investment projects despite their inability to foresee the future outcome of their investment decisions.

Investors are compelled to make investment decisions on the basis of expectations, which are informed by a variety of social conventions, including perceptions about movements in financial asset prices. An environment characterized by the aggressive pursuit of capital gains can exacerbate the volatility of financial asset prices, thereby provoking instability in expectations and further intensifying the perils of embarking on investment decisions. ${ }^{27}$

${ }^{27}$ Unlike Neoclassicals, Keynesians appeal to no underlying "fundamentals" that govern financial asset prices. While both theories concur that investors consider the future rate of return on a proposed investment project, Keynesians believe that investors have no possibility of even probabilistic information about the future rates of return on so-called "momentous" investment decisions. Thus for Keynesians, arbitrage in financial assets does not have the stabilizing properties of establishing the correct price reflecting underlying fundamentals (à la neoclassical economic theory), but instead the attempt to profit from short term price fluctuations can exacerbate price instability and thereby distort the expectations formation process. (See Crotty, 1994) 
From a Marxian class analytic perspective, the Keynesian analysis of fundamental uncertainty and the expectations formations process implies a contradictory attitude towards the pursuit of capital gains. The possibility of realizing capital gains can put downward pressure on the subsumed class payment required to secure money capital. However, Keynesians do not wish the pursuit of capital gains to dominate the conduct of financial intermediation to the extent that productive capital is made hostage to the vagaries of speculation in financial assets. Although Keynesians do not commit themselves on the precise point at which the pursuit of capital gains begins to undermine the subsumed class role of financial intermediaries, the laudable situation (financial intermediation geared primarily towards the promotion of accumulation) is usually distinguished from the undesirable situation (financial intermediation geared toward capital gains in financial assets) by reference to Keynes' distinction between "speculation" and "enterprise". In the General Theory, Keynes contrasts "enterprise", or the "activity of long term investment concerned with the yield of assets over their whole life" (Keynes, 1973, 158) with "speculation," or the attempt to garner profits by anticipating market psychology to take advantage of short-term fluctuations in prices. ${ }^{28}$ It is interesting that the famous passage condemning speculation in the General Theory is followed by a less frequently quoted condemnation of the speculative proclivities of Wall Street:

Speculators may do no harm as bubbles on a steady stream of enterprise. But the position is serious when enterprise becomes the bubble on a whirlpool of

\footnotetext{
${ }^{28}$ Grabel quotes a useful definition of speculation devised by Nicholas Kaldor: "' [speculation is] the purchase (or sale) of goods with a view to re-sale (or repurchase) at a later date, where the motive behind such action is the expectation of a change in the relevant prices ... and not a gain accruing through their use, or any kind of transformation effected in them or their transfer between different markets." (in Grabel 1999, 1076-1077)
} 
speculation. When the capital development of a country becomes a by-product of the activities of a casino, the job is likely to be ill-done. The measure of success attained by Wall Street, regarded as an institution of which the proper social purpose is to direct new investment into the most profitable channels in terms of future yield, cannot be claimed as one of the outstanding triumphs of laissez-faire capitalism - which is not surprising, if I am right in thinking that the best brains of Walls Street have been in fact directed towards a different object. (Keynes 1973, 159)

Keynes also acknowledged that speculation may have damaging consequences for economic growth for other reasons. Keynes' Treatise on Money, published in 1930 , included references that pointed out that a central bank may seek to deter excessive speculation on financial markets by increasing interest rates in the attempt reduce the flow of funds into speculative purposes. Such a policy also increases the subsumed class payment required to secure money capital. Keynes was persuaded that the Federal Reserve had taken this course of action during the late 1920s, and that this had put sufficient upward pressure on the costs of investment that it provoked the subsequent economic downturn:

Nevertheless, the high market-rate of interest which, prior to the collapse, the Federal Reserve System in their effort to control the enthusiasm of the speculative crowd, caused to be enforced in the United States - and as a result of sympathetic self-protective action, in the rest of the world - played an essential part in bringing about the rapid collapse. For this punitive rate of interest could not be prevented from having its repercussion on the rate of new investment both in the United States and throughout the world, and was bound, therefore, to prelude an era of falling prices and business losses everywhere.

Thus I attribute the slump of 1930 primarily to the deterrent effects on investment of the long period of dear money which preceded the stock-market collapse, and only secondarily to the collapse itself. (Keynes 1930, 196) ${ }^{29}$

\footnotetext{
${ }^{29}$ The question of the actual orientation of monetary policy prior to the stock market crash is somewhat contentious, with authors such as Friedman and Schwartz claiming that monetary restraint was actually eased after 1927. Our purpose is not to resolve this debate, but rather to suggest that Keynes believed this to be true, and thus this perception was likely influential among Keynesians.
} 
A third potential response of financial capitalist firms to pressure on their profitability concerns a migration towards the assumption of increased risk in their financial capitalist activities. This method of increasing value inflows differs from those discussed in the previous paragraphs since it can concern a change in the way that financial capitalist firms conduct their subsumed class lending as well as their non-class lending. The interest income received by a financial capitalist firm increases in instances where the perceived risk associated with the provision of money capital increases. Thus by engaging in lending to borrowers that seek to undertake activities that are perceived as risky, financial capitalist firms may enhance their profitability. However, with the assumption of greater risk comes the increased likelihood that the borrower may not be able to make required interest payment, or the money capital may be lost in its entirety.

When a borrower defaults entirely, there may be some collateral that the bank can use to defray the loss of the principal of the loan. However, the conditions that culminated in the inability of the borrower to meet its interest payment obligations (say the inability to appropriate surplus value in their productive capitalist firm) may also depreciate the value of the collateral backing the loan. For example, if the borrower has been unable to appropriate surplus value because of a crisis in a particular industry, then any means of production or securities related to the industry in distress are likely to fetch less for the commercial bank seeking to recover its losses on the defaulted loan. In a general economic downturn, the liquidation of all of the forms of collateral backing bank loans in default creates a general asset deflation, and increases the likelihood that the solvency of commercial banking system will be jeopardized. 
Defaults by borrowers have the potential to plunge the financial capitalist firm into a crisis. If many financial capitalist firms face defaults simultaneously, this has the potential to destabilize financial intermediation generally, as losses of this kind can persuade savers to regard financial capitalist firms as insecure places in which to hold savings. Thus the migration to riskier activities implies a further contradiction. Because it enables financial capitalist firms to earn greater subsumed class revenues, it may be that migration toward greater risk will enable financial capitalist firms to enhance their profitability. However, in the event that greater risk leads to crisis among financial capitalist firms, this can destabilize financial intermediation, which in turn threatens capital accumulation.

Financial capital may also blend various avenues of non-class revenue generation. For example, loans may be made for the purchase of securities on secondary markets. The degree to which financial capitalist engage in this form of lending will exert influence on the demand conditions on securities markets, which in turn may accentuate the volatility of financial asset prices. Financial capitalists may migrate towards making these loans for increasingly risky attempts to secure capital gains. Securities may even be offered as collateral to support loans to purchase additional securities, which renders financial capitalists (and the conduct of financial intermediation in general) vulnerable should securities prices drop and destabilize loan portfolios. The synergies amongst these strategies can culminate in a situation that is an anathema for Keynesian financial reform. If financial intermediation is increasingly conducted in a manner that exacerbates the 
volatility in financial markets and compromises the stability of financial intermediaries, Keynesians fear that the conditions of existence for stable and vigorous investment spending will be compromised. While not opposing the pursuit of capital gains outright (since it may be a condition of existence for low subsumed class payment to secure money capital) or the assumption of risk on the part of financial capitalists (since risk is inherent in the provision of money capital), Keynesians tend to condemn financial environments that they perceive have become overly speculative.

The potential for financial capitalists to engage in all of these avenues of earning non-class revenues further overdetermines the Keynesian pro-accumulation agenda. In the event that this Keynesian agenda exacerbates the Keynesian master/servant contradiction, financial capitalists could respond to pressure on their profitability by engaging in the pursuit of capital gains and the assumption of heightened risk. In turn, these responses may undermine the Keynesian accumulation agenda. Thus each intervention on the part of Keynesian financial regulators that is potentially injurious to financial capitalist profitability has the potential to set in motion actions that might undermine the accumulation agenda that Keynesian financial reformers intended to support. The Marxian class analytic perspective appreciates the enormous complexity of attempting to manage these sometimes entropic contradictions. Without the perspective of overdetermination, Keynesian financial reforms may appear as a pastiche of incongruent regulatory impulses. Indeed, as the New Deal financial reforms were being unraveled in the 1990s, opponents of this Keynesian financial regulatory framework portrayed themselves as advocates of "financial modernization", thus positioning 
themselves in opposition to a regulatory structure that was implied to be archaic or perhaps even perversely irrational. However, from an overdeterminist point of view, it is not surprising the New Deal financial reforms had multiple objectives as it attempted to cope with both the positive and negative moments of the Keynesian master/servant contradiction. 


\section{CHAPTER 3}

\section{THE CLASS ANALYTICS OF COMMERCIAL BANKING: \\ FURTHER CONSIDERATIONS IN THE SUBSUMED CLASS STRUGGLES INVOLVING FINANCIAL CAPITAL}

\section{Introduction}

The second chapter presented a generic class analysis of financial capital in order to describe the Keynesian master/servant contradiction and some of its implications for New Deal financial reforms. The third chapter develops the class analytics of a particular type of financial capitalist firm, the commercial bank, to refine the analysis of subsumed class struggles involving financial capital that overdetermined the New Deal financial reforms. As chapter two argued, the terms "types" or "categories" of financial capitalist activity is used to refer to the characteristic way in which a financial capitalist gathers savings in the first moment of financial intermediation. Thus a commercial bank is distinguished by its acceptance of deposits, a pension fund by its receipt of pension fund contributions and so on. The class analysis undertaken in this chapter begins with the assumption that financial capitalist firms conduct only one type of financial capitalist activity. Thus a firm called a "commercial bank" engages only gathering savings via deposits, and refrains from engaging in other types of financial capitalist activities connected with investment banking, the provision of insurance ${ }^{1}$, pensions and so on. Later this assumption is relaxed to consider the "diversified financial capitalist firm", meaning a financial capitalist firm that engages in multiple types of financial capitalist activities.

\footnotetext{
' The insurance provision referred to is insurance with a savings element.
} 
Commercial banks have been selected as a particular focus of this dissertation for a variety of reasons. Historically the money-lending activities of commercial banks have been an important condition of existence for the capitalist fundamental class process. For a variety of historically and institutionally specific reasons, it has evolved that commercial banks also facilitate transactions in a market economy, and act as the transmission mechanism for monetary policy. Because of the multiple conditions of existence that commercial banks provide for contemporary surplus value appropriation, and because of the vulnerability of commercial banks inherent in a partial reserve system, it has evolved that the state has a unique relationship with the commercial banking system. By exploring the peculiarities of commercial banking as a unique type of financial capitalist activity, we arrive at a more nuanced understanding of the subsumed class struggles among financial capitalist firms, which in turn overdetermines the subsumed class payment required to secure money capital.

\section{The Class Analysis Of Commercial Banking}

Commercial banks acquire funds for subsequent re-lending by accepting deposits. The inflow of funds that commercial banks receive when they obtain new deposits is a non-class revenue. The majority of these new deposits are used to make loans, either to surplus value appropriators (in which case the new loan is an X payment) or to others such as individuals, unproductive capitalist firms or states ${ }^{2}$ (in which case the new loan is

\footnotetext{
${ }^{2}$ For simplicity, we omit the possibility that the bank makes a loan to non-capitalist surplus appropriators.
} 
a Y payment). However, the "partial reserve system" employed in the United States ${ }^{3}$ legally obliges commercial banks to withhold a portion of their new deposits as required reserves. ${ }^{4}$ Required reserves constitute a Y payment for commercial banks, and these funds must be held in non-interest bearing accounts at the Federal Reserve. ${ }^{5}$ The interest income that is received by commercial banks when interest is paid on loans is either a subsumed class revenue (if the borrower is an appropriator of surplus value), or a nonclass revenue (if not). Banks, like other financial capitalist firms, also may incur expenses associated with acquiring loanable funds. Since we assume that banks acquire loanable funds only via deposits, the interest paid on deposits is a Y expense. In addition, there are other Y expenses associated with occupancy costs, salaries and so forth, and these and other residual expenses comprise the term "Y other expenses". Finally, when a loan is repaid to the commercial bank, this constitutes a non-class revenue.

Figure 4: Commercial Banking Value Inflows and Expenditures

\begin{tabular}{l} 
Value Inflows: \\
NCR $\Delta$ bank deposits $+S S C R$ interest income from loans to surplus value appropriators $+N C R$ interest income from \\
loans to non-surplus value appropriators $+N C R_{\text {loan repayment }}$ \\
Value Expenditures: \\
$Y_{\text {interest paid to secure bank deposits }}+\mathrm{X}_{\text {loans to surplus value appropriators }}+\mathrm{Y}_{\text {loans to non-surplus value }}$ \\
appropriators \\
\hline
\end{tabular}

\footnotetext{
${ }^{3}$ The partial reserve system is the traditional manner in which depository banking has been conducted. However, recently some jurisdictions have excused depository institutions from the necessity of holding required reserves. Chapter six will discuss some of the ways in which depository institutions have been able to reduce and in some cases eliminate required reserves.

${ }^{4}$ This is an approximation of how required reserves are created. In fact, required reserves are generally acquired by trading among commercial banks in the Federal Funds market, rather than by holding aback a portion of each new deposit. However, this approximation is employed in standard texts as an explanation of the banking process and the money multiplier.

${ }^{5}$ Cash held on the premises of commercial banks (vault cash) is also counted as required reserves.
} 
To derive a statement of commercial bank profits, the relevant value inflows and expenditures connected to value expansion are extracted from Figure 4 to create Figure 5 below.

Figure 5: Commercial Banking Profits

$$
\begin{aligned}
& \text { Commercial Banking Profit } \\
& {\left[\mathrm{SSCR}_{\text {interest income from loans to surplus value appropriators }}+\mathrm{NCR}\right. \text { interest income from loans to non-surplus value }} \\
& \text { appropriators }]-\left[\mathrm{Y}_{\text {interest paid to secure bank deposits }}+(\mathrm{X}+\mathrm{Y})_{\text {expenses associated with advancing loans }}+\mathrm{Y}_{\text {other }}\right. \\
& \text { expenses }]
\end{aligned}
$$

The preceding class analysis of commercial banking makes several important assumptions concerning both the first and second moments of financial intermediation. It is assumed that banks access savings exclusively by accepting deposits. This precludes the possibility that commercial banks might issue certificates of deposit or commercial paper, and use these so-called "purchased funds" to make loans. These forms of nondeposit liabilities used by commercial banks to fund loans may be used by many types of financial capitalists. In order to focus on the unique activity of commercial banking, these types of non-depository activities common to all financial capitalists have been eliminated from the class analytic definition of commercial banking. In terms of the second moment of financial intermediation, we assume that commercial banks are exclusively engaged in making loans. We thus disallow the possibility dividends or capital gains may be earned in commercial banking. Furthermore, we assume that loans are made to both productive capitalist firms and others, so by this definition we exclude 
any specialized depository institutions, such as savings and loan associations, that were designed to make loans for solely non-class purposes (such as loans to individuals for residential housing purchases).

The preceding analysis of commercial banking is highly simplified in order to highlight the unique properties of this particular type of financial capitalist activity. However, in seeking to analyze the commercial bank as a firm, we must confront other value inflow and expenditures that typically occur inside this type of financial capitalist firm. For example, the preceding class analysis assumed that banks are fully "loaned up" (i.e. that all funds on deposit are either directed to new loans or required reserves). However, it is possible that commercial banks may leave funds idle if conditions are such that extending new loans is not perceived as lucrative for the commercial bank. In that event, the commercial bank is deemed to have "excess reserves". Since required reserves bear no interest, holding funds as reserves in excess of the legal requirement represents forgone income for a commercial bank. In order to earn income on funds that are not in use as either required reserves or new loans, commercial banks may hold these funds in the form of government securities. It has evolved that holding funds in this form is deemed permissible by banking regulators, since government securities allow commercial banks to earn some interest income, yet they are regarded as being highly liquid and having little risk of default (although they are not a substitute for required reserves, since in a banking crisis the holding of government securities offers less effective protection than do required reserves ${ }^{6}$ ). In the event that a commercial bank holds government

\footnotetext{
${ }^{6}$ Required reserves are always accessible at face value, but if large amounts of government securities are liquidated at the same time, this may reduce the amount that these securities fetch in the market for
} 
securities in this manner, the class analysis of commercial banks presented above would be amended. Interest earned on government securities would be a non-class revenue, as would be any capital gains made on the sale of these securities. Another non-class revenue would be any repayment of the principal of the government security. On the value outflow side, the $\mathrm{Y}$ costs associated with purchasing these securities constitutes an additional expense.

A second consideration in the class analysis of commercial banks are the various activities that are typically incidental to commercial banking but are outside of the definitional limits of commercial banking imposed above. Revenues which are not interest payments on loans advanced by the commercial bank are deemed non-interest income. For example, any gains realized because of fluctuating exchange rates that affect foreign currency transactions would be recorded as non-interest income. Within the category of non-interest income are various revenues typically referred to as "fee income". Fee income is generated by a great range of activities, from fees levied on deposit accounts (say for the use of an automatic banking machine) to fees earned in return for the provision of a safety deposit box. As chapter seven explains, fee income is also earned on a host of activities that are increasingly peripheral to the traditional commercial bank role of taking deposits and making loans. It would require a detailed class analysis of each fee-generating activity to see if that activity constitutes the production of a commodity. This analysis is forgone here, and we shall assume that all fee income should be considered a non-class revenue. Any such non-class revenue will 
entail expenses, but in practice it is difficult to match commercial bank expenses to the income they generate. 'We simplify this issue by recording all of these expenses under the term "Y other expenses".

The class analysis of the profits of a commercial bank can be created by taking the class analytic statement of the profits of commercial banking (depicted in Figure 5) and adding these additional forms of value expansion that typically occur within a commercial bank. Figure 6 presents this as the class analytic statement of commercial bank profits. Whereas Figure 5 represented the profits of commercial banking as a financial capitalist activity (that is the strictly defined activity of taking deposits and using those deposits to fund loans), Figure 6 includes the other forms of revenues and expenses that are incidental to the practice of commercial banking in order to represent the profits of the financial capitalist firm referred to as a commercial bank.

Figure 6: Class Analysis of Commercial Bank Profits

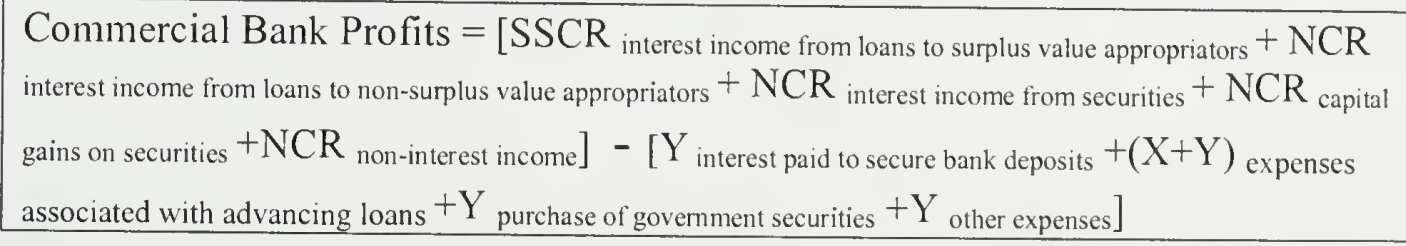

${ }^{7}$ For example, a bank employee may be involved in multiple activities during the workday that include both activities associated with securing the traditional subsumed class and non-class revenue from loans and activities associated with earning fee income. 


\section{Using Conventional Banking Data To Conduct A Class Analysis Of Commercial Banks}

The class analytic statement of commercial bank profits presented in Figure 6 provides the framework for our analysis in subsequent chapters of New Deal financial reforms and their impacts on commercial bank profitability. An empirical application of this class analytic framework requires data with which to assess the developments in the various value inflow and outflow categories. However, the non-Marxian format in which banking data is collected does not immediately lend itself to class analytic concerns. This section confronts this problem by dissecting the non-Marxian categories used to format available data in order to reconstitute them in a manner that can address class analytic concerns more directly.

The Historical Statistics on Banking (HSOB) published by the Federal Deposit Insurance Corporation (FDIC) has been selected as the primary source of data used to create a class analytic account of commercial bank profitability. FDIC data is considered an authoritative source of the aggregate information contained in the income statements and balance sheets of FDIC-member commercial banks, and it has been collected in a relatively consistent fashion since the inception of the FDIC in $1934 .{ }^{8}$ All data used from this source pertains to commercial banks that are members of the FDIC, but this arguably constitutes a reasonable proxy for all US chartered commercial banks. In some instances, FDIC data is not appropriate for a particular discussion, and in that event data is used

\footnotetext{
${ }^{8}$ Of course, the FDIC has adapted the ways in which it categorizes and presents bank data as commercial banking, accounting protocols and public policy concerns have evolved. Thus within FDIC statistics there are some inconsistencies in the way in which particular items are classified over time. A very detailed account of the various changes made in the presentation of data contained in the Historical Statistics on Banking is presented on the FIDC website at www2.fdic.gov/hsob/HSOBNotes
} 
from the Flow Of Funds published by the Federal Reserve. Prior to 1934 the availability of data that is commensurate with both the Flow of Funds and the HSOB is more limited. Chapters four and five will rely on the Banking and Monetary Statistics published by the Federal Reserve for this purpose.

The reconstitution of non-Marxian banking data into class analytic categories is divided into the revenue and expenditure components. Table 1 summarizes the ways in which the four non-Marxian revenue categories of commercial banks are decomposed and rearranged as the five class analytic value inflow categories. The aggregated FDIC data makes it impossible to determine the extent to which loans are made to appropriators of surplus value versus other entities. Thus for present purposes, the two Marxian categories "SSCR interest income from loans to surplus value appropriators" and "NCR interest income from loans to non-surplus value appropriator" are combined. This combined subsumed and non-class interest income category corresponds to a subset of the FIDC categories that constitute "total interest income". From "total interest income" we have extracted "interest income loans and leases" and the majority of "other interest income" as the approximation of the interest income from subsumed class and non-class loans. The final elements of FDIC's "total interest income", namely "interest income on investment securities" and "other interest income: trading account assets", has been displayed separately to illustrate the non-class revenue earned as interest income on investment securities. "NCR non-interest

\footnotetext{
${ }^{9}$ Interest income on trading account assets are not included as interest income from loans in the class analytic category SSCR interest income from loans to surplus value appropriators $+\mathrm{NCR}$ interest income from loans to non-surplus value appropriators
} 
income" is composed of both "total non-interest income" and "net extraordinary items" from the FDIC classifications. Finally "NCR capital gains on securitie" is considered to be the FIDC category "securities gains/losses". 
Table 1: A Comparison Of FDIC Revenue Categories And Class Analytic Value Inflow Categories Related To Commercial Bank Profit

\begin{tabular}{|c|c|c|c|}
\hline \multicolumn{2}{|c|}{ FDIC CATEGORIES } & \multicolumn{2}{|c|}{ CLASS ANALYTIC CATEGORIES } \\
\hline \multicolumn{2}{|r|}{ Income } & \multicolumn{2}{|c|}{ Value Inflows } \\
\hline $\begin{array}{l}\text { Total } \\
\text { Interest } \\
\text { Income }\end{array}$ & $\begin{array}{l}\text { Interest income loans } \\
\text { and leases } \\
\text { Interest income } \\
\text { investment securities } \\
\text { Other interest income } \\
\text { (trading account } \\
\text { assets }{ }^{10}, \text { federal funds, } \\
\text { balances due from } \\
\text { depository institutions) }\end{array}$ & $\begin{array}{l}\text { SSCR } \text { interest } \\
\text { income from loans to } \\
\text { surplus value } \\
\text { appropriators } \\
+\mathrm{NCR}_{\text {interest }} \\
\text { income from loans to } \\
\text { non-surplus value } \\
\text { appropriators } \\
\end{array}$ & $\begin{array}{l}\text { Interest income } \\
\text { loans and leases } \\
\text { Other interest } \\
\text { income (federal } \\
\text { funds, balances due } \\
\text { from depository } \\
\text { institutions) }\end{array}$ \\
\hline & & $\begin{array}{l}\text { NCR } \text { interest income } \\
\text { from securities }\end{array}$ & $\begin{array}{l}\text { Interest income } \\
\text { investment securities } \\
\text { Other interest } \\
\text { income(trading } \\
\text { account assets) }\end{array}$ \\
\hline $\begin{array}{l}\text { Total non- } \\
\text { interest income }\end{array}$ & $\begin{array}{l}\text { - Fee income }{ }^{11} \\
\text { - Other non-interest } \\
\text { income }\end{array}$ & $\begin{array}{l}\text { NCR non-interest } \\
\text { income }\end{array}$ & $\begin{array}{l}\text { - Fee income } \\
\text { - Other non-interest } \\
\text { income } \\
\text { - Net extraordinary } \\
\text { items } \\
\end{array}$ \\
\hline $\begin{array}{l}\text { Securities } \\
\text { gains/losses }\end{array}$ & $\begin{array}{l}\text { - Securities } \\
\text { gains/losses }^{13} \\
\end{array}$ & $\begin{array}{l}\text { NCR capital gains on } \\
\text { securities }\end{array}$ & $\begin{array}{l}\text { Securities } \\
\text { gains/losses }\end{array}$ \\
\hline $\begin{array}{l}\text { Net Extra- } \\
\text { ordinary items }\end{array}$ & $\begin{array}{l}\text { - Any additional } \\
\text { income }^{14}\end{array}$ & & \\
\hline
\end{tabular}

${ }^{10}$ This statistic was not collected until 1983. Prior to that, any interest income from trading account assets was included under "non-interest income- all other".

${ }^{11}$ Fee income includes "service charges on deposit accounts in domestic offices such as maintenance fees, activity charges, administrative charges, overdraft charges, and check certification charges".

(www2.fdic.gov/hsob/HSOBNotes)

${ }^{12}$ Other non-interest income includes "income from fiduciary activities; gains, losses and fees relating to foreign currency or foreign exchange transactions; gains, losses and fees from assets held in trading accounts; net gains from the sale or disposition of loans, premises (including branches and offices) and fixed assets, and other real estate owned; all service charges, fees and commissions (other than those relating to deposits in domestic offices); fees charged on bank issued credit cards; net gains on futures and forward contracts; and other miscellaneous income". (www2.fdic.gov/hsob/HSOBNotes)

${ }^{13}$ This category represents "the net value of profits on securities sold or redeemed less losses on securities sold". (www2.fdic.gov/hsob/HSOBNotes)

${ }^{14}$ Net extraordinary items represents "the results of material events and transactions that are both unusual and infrequent, net of income taxes". (www2.fdic.gov/hsob/HSOBNotes) 
The comparison of FDIC expense categories and class analytic value outflow categories is presented in Table 2. On the expense side, "Y $Y_{\text {interest paid to secure bank deposits" }}$ consists of one of the two elements of total interest expense, namely "interest on deposits". The class analytic category " $(\mathrm{X}+\mathrm{Y})$ expenses associated with advancing loans" consists of the other subcategory of total interest expense, namely "other interest expenses". "Other interest expenses" consists of the interest expense on funds that commercial banks have borrowed, including borrowings to support their lending activities. Since this is a non-deposit source of funds for commercial banks, this constitutes a movement away from commercial banking as it has been defined in this dissertation. Thus this category is separated out to facilitate the discussion in chapter seven of changes in the roles of commercial banks. The class analytic category "Y other expenses" acts as a residual for all other expenses. 

Table 2: A Comparison Of FDIC Expense Categories And Class Analytic Value Outflow
Categories Related To Commercial Bank Profit

\begin{tabular}{|c|c|c|c|}
\hline \multicolumn{2}{|c|}{ FDIC CATEGORIES } & \multicolumn{2}{|c|}{ CLASS ANALYTIC CATEGORIES } \\
\hline \multicolumn{2}{|r|}{ Expenses } & \multicolumn{2}{|c|}{ Value outflows } \\
\hline $\begin{array}{l}\text { Total interest } \\
\text { expense }\end{array}$ & $\begin{array}{l}\text { - Interest on deposits } \\
\text { Other interest } \\
\text { expenses }\end{array}$ & $\begin{array}{l}Y_{\text {interest paid to secure bank }} \\
\text { deposits }\end{array}$ & - Interest on deposits \\
\hline & & $\begin{array}{l}(\mathrm{X}+\mathrm{Y}) \text { expenses } \\
\text { associated with advancing } \\
\text { loans }\end{array}$ & $\begin{array}{l}\text { Other interest } \\
\text { expenses }\end{array}$ \\
\hline $\begin{array}{l}\text { Total non- } \\
\text { interest expense }\end{array}$ & $\begin{array}{l}\text { - Employee Salaries } \\
\text { and Benefits } \\
\text { - Occupancy costs } \\
\text { - All other non- } \\
\text { interest expenses }{ }^{16}\end{array}$ & $\mathrm{Y}_{\text {other expenses }}$ & $\begin{array}{l}\text { Employee Salaries } \\
\text { and Benefits } \\
\text { - Occupancy costs } \\
\text { All other non- } \\
\text { interest expenses } \\
\text { Total applicable } \\
\text { taxes } \\
\end{array}$ \\
\hline $\begin{array}{l}\text { Total applicable } \\
\text { taxes }\end{array}$ & $\begin{array}{l}\text { Total applicable } \\
\text { taxes }\end{array}$ & & \\
\hline
\end{tabular}

By dismantling the FDIC categories and rearranging them to create an approximation of class analytic categories, it is possible to work within the confines of mainstream data to pursue class analytic concerns. This is convenient in that it enables Marxists to use many of the conventional banking statistics for class analytic concerns. For example, conventional measures of profitability in banking literature include the

\footnotetext{
${ }^{15}$ Other interest expense consists of interest expenses on federal funds purchased, borrowed money, subordinated notes and debentures.

${ }^{16}$ Non-interest expense includes "fees paid to directors, trustees and advisory board members; premiums on fidelity insurance and deposit insurance; retainer and legal fees; net losses from the sale or disposition of loans, premises and fixed assets, other real estate owned, and branches; management fees assessed by parent bank holding companies; advertising, public relations, and promotional expenses; amortization expense of intangible assets; charitable contributions; net losses on futures and forward contracts; office supplies; telephone expenses; examination and audit fees; charge-offs and writedowns of securities prior to sale; and other miscellaneous expenses". (www2.fdic.gov/hsob/HSOBNotes)
} 
Return on Assets (ROA), the ratio of net income to average total assets, and Return on Equity (ROE), the ratio of net income to average equity capital. Since this method of reconstituting FDIC data preserves the overall totals of revenues and expenditures, the numerator of these ratios remains unchanged in our Marxian analysis. Thus the ROA and ROE can also be employed as a class analytic depiction of commercial bank profitability (expressed relative to the size of assets or the equity of commercial banks). This is advantageous in that it allows us to use the indicator of profitability familiar to mainstream banking analysis, yet re-present this profitability indicator in order to discern the class analytic dynamics that shape it.

\section{Unique Aspects Of Commercial Banks And Their Impacts On Subsumed Class Struggles}

Commercial banks are unique among financial capitalist firms in that they provide several conditions of existence for surplus value appropriation in a contemporary market economy. Like other money-lending financial capitalist firms, commercial banks provide credit to productive capitalist firms and others, but in addition commercial banks also help to execute transactions and implement monetary policy. While commercial banks have the capacity to be immensely supportive to the capitalist fundamental class process, they also have the capacity to threaten it, both by refraining from providing money capital and by difficulties stemming from the other roles of commercial banks. In a partial reserve system in which deposits are payable on demand to facilitate transactions, commercial banks are vulnerable to a contagion of bank failures, which can expose the entire economy to profound crisis. Because of the unique capacity of commercial banks to both support and devastate economic activity, it has evolved that commercial banks 
have a relationship with the state that is unlike that of other types of financial capitalist firms. This section presents some of these unique qualities of commercial banks in order to analyze how these considerations overdetermine the subsumed class struggles among the various types of financial capitalist firms.

Savings held as deposits play a role that savings held in other forms have traditionally not played. It has evolved that checkable "transactions" deposits may be used to execute purchases. Thus in addition to providing credit, commercial banks also facilitate the payments system in a contemporary market economy. To enable deposits to serve as a means of payment, these so-called checking deposits are payable on demand. This requirement that checking deposits be payable on demand exacerbates the mismatch between the potentially short-term longevity of the liabilities (deposits) and the longerterm longevity of assets (loans) of commercial banks. In a partial reserve system it is possible that a bank may fail if it does not have sufficient funds available to meet the withdrawals of depositors. Moreover, the partial reserve system creates a web of interconnection among commercial banks since the loans made by one bank become the deposits held by other banks, which fund further lending and deposits in still more banks. Thus bank failures may spread if the contraction in the deposits of a failed bank puts pressure on otherwise solvent banks to contract their deposits. The ensuing contagion of bank failures compromises both the subsumed class role of commercial banks (since it contracts lending) and the ability of deposits to execute transactions (since checks may not be honored if the capacity of banks to settle their accounts with one another is put into question). 
In addition to the provision of crcdit and the facilitation of transactions, commercial banks are also involved in the provision of a third condition of existence for a contemporary capitalist economy. The partial reserve system involves commercial banks in the creation of money, since any new money acquircd by commcrcial banks for usc as required reserves (so-called high powered money) can expand the money supply by many times the initial increment in reserves. Thus the state can manipulate the money supply by affecting the ability of commercial banks to access reserves. However, the money multiplier also works in reverse to destroy money when commercial bank failures force loans to be called in, thus potentially provoking further bank failurcs that can depress economic activity by contracting the money supply. Since a banking sector in distress is no longer a reliable transmission mechanism for monetary policy, widespread bank failures cause the state to lose control over the money supply.

Since the state's ability to affect the level of the money supply is only discharged via the lending activities of commercial banks, the state and commercial banks have a principal agent relationship. This principal agent relationship inherent in monctary policy transmission under these institutional arrangements reinforces the unusual characteristics of the state's relationship to commercial banks. The state's subsumed class responsibilities include safeguarding the general conditions of existence of the capitalist class process, including the availability of credit, the capacity to cxecutc transactions, as well as control over the money supply. Thus the state rcgards commcrcial banks as special among financial capitalist firms becausc of the multiple roles they play in 
supporting the capitalist fundamental class process. Hence commercial banks are distinguished among financial capitalist firms because the state has a unique incentive to promote the solvency of commercial banks, since insolvent commercial banks may provoke the contagion of bank failures that compromises all three of the roles of commercial banks. Since commercial bank profitability helps to deter bank failures, the state has an incentive to ensure that commercial banks on the whole are adequately profitable lest insolvencies among commercial banks provoke a crisis in commercial banking. While the failure of other types of financial capitalist firms may produce crises of various sorts, other financial capitalist activities lack the particular institutional mechanisms that compel the state to regard their failure as a systemic threat. ${ }^{17}$ Shutt quotes a recent OECD report ${ }^{18}$ explanation of the unique importance of commercial banks :

Because of the banks role in the creating money in this institutional context, it is of utmost importance to the state that banks be sound. A continuous supervisory role for the state in the area of commercial banking occurs because banks and their liabilities are seen as special. They are special because they have the attributes of public goods. Money is the means of payment in a capitalist economy .... And in order to preserve systemic stability confidence in the institutions that hold these liabilities is a public policy necessity. $(1998,69)$

This unique incentive on the part of the state to promote commercial bank profitability overdetermines the master/servant contradiction of the Keynesian agenda. The Keynesian agenda to secure a low subsumed class payment for access to money

\footnotetext{
${ }^{17}$ To the extent that the provision of money capital is a condition of existence of capitalist exploitation, the state has an interest in the continued functioning of all financial capitalist firms. However, these additional conditions of existence provided by commercial banking give the state additional incentive to enable commercial banks to continue to fulfil their various roles.

${ }^{18}$ Regulatory Reform In The Financial Services Industry: Where Have We Been? Where Are We Going? No. 67, June 1997.
} 
capital potentially jeopardizes the profitability of the financial capitalists that are obliged to provide money capital on terms that are attractive to productive capital. Chapter two argued that financial capitalists may resist this squeeze on their profitability by finding alternative avenues for value expansion rather than fulfilling their subsumed class rolc of providing money capital to surplus value appropriators. Thus the attempt to support accumulation via low subsumed class payments to obtain money capital may subvert accumulation. This master/servant contradiction is further overdetermined if the financial intermediaries in question are commercial banks. A profitability squeeze on commercial banks potentially has additional disruptive impacts given the institutional characteristics of contemporary commercial banking. Thus a state contemplating the implementation of a Keynesian agenda faces additional complications because of the unique characteristics of commercial banking. Not only must it assure that financial intermediaries are sufficiently profitable that they continue to fulfill their subsumed class responsibilities; it must also insure that commercial banks are sufficiently profitable that the commercial banking system is protected from the potentially far-ranging damage generate by bank failures. 


\section{The State And Regulation Of Commercial Banking: Further Overdeterminants To Subsumed Class Struggle Among Financial Capitalists}

Given the unique relationship between commercial banks and the state, it has evolved that the state has assumed the authority to regulate commercial banks in an effort to safeguard the stability of the commercial banking system. Regulators seek to prevent behavior on the part of commercial banks that may induce commercial banking crisis, and the state also has some extraordinary powers that are designed to safeguard the stability of the banking system should difficulties arise. In the course of exerting their regulatory authority to shape commercial bank behavior, the state provides commercial banks with certain privileges that are not available to other types of financial capitalist firms. At the same time commercial banks are also subject to various constraints that do not affect other financial capitalist firms. This assortment of both privileges and constraints entailed by this unique relationship between the state and commercial banks further overdetermines subsumed class struggle involving commercial banks.

In an effort to enhance the stability of a partial reserve commercial banking system where deposits are payable on demand, the state often imposes required reserves to protect commercial banks from so-called "liquidity risk". Required reserves were conceived as a source of funds that would be readily accessible to meet the demand of depositors for cash and thereby deter bank failures. Thus the solvency and stability of the commercial banking system as a whole is enhanced to the extent that required reserves 
are held. ${ }^{19}$ However required reserves also overdetermine commercial bank profitability. Required reserves are funds that are made unavailable to create new loans, thus reserve requirements constrain the profitability of commercial banks. By enforcing required reserves, banking regulators face the contradictory consequences of both detracting from commercial bank profitability (which is a condition of existence for the solvency of the banking system), and paradoxically enhancing the solvency of the banking system (which is a condition of existence for commercial bank profitability). Other financial capitalist firms are not subject to this constraint on their ability to generate income with the funds they attract in the first moment of financial intermediation, therefore required reserves put commercial banks at a competitive disadvantage vis à vis other financial capitalist firms. For this reason, commercial bankers derisively refer to required reserves are as a "tax" on commercial banking.

State banking regulators constrain commercial banking activity in other ways in order to compel commercial banks to conduct themselves in a manner which is seen as conducive to the stability of the commercial banking system. In keeping with this desire to preserve the stability of the commercial banking system, regulators seek to constrain the risks that commercial banks incur, since higher risk activities are associated with a greater likelihood of failure (as well as an increased payoff if they are successful). In each case that regulators constrain the risks undertaken by commercial banks, they also affect commercial bank profitability (which reacts back to overdetermine the stability of the

\footnotetext{
${ }^{19}$ Paradoxically, the existence of sizable required reserves may render them unnecessary, since awareness of the sufficiency of required reserves dissuades depositors from instigating a run on the bank, while the diminution or removal of required reserves may render them vital.
} 
commercial banking system), and they put commercial banks at a disadvantage vis à vis their non-bank competitors. For example, commercial banks arc often preventcd from extending a large percentage of their lending to a single borrower (or even a single sector of the economy, such as mining, oil etc.). This restriction is intended to shield banks from a crisis that emanates from a single firm (or sector), however it prevents commercial banks from participating fully in the profitable opportunities when a boom is experienced in that firm (or sector). Restrictions are also placed on the types of securities commercial banks are entitled to hold. Commercial banks are often permitted to purchase only those government securities that were judged to be of very high quality. The intention of regulators is that there securities provide banks with modest income while enabling them to manage incidental mismatches between inflows of funds, lending opportunities, and the potential withdrawals of depositors. Regulators wish to dissuade commercial banks from using their securities portfolio to speculate in pursuit of capital gains, since is deemed excessively risky and likcly to expose the banking system to heightened risk of bank failures. However, to the extent that the state constrains the profit generating options of commercial banks, this creates a dilemma for commercial banks qua capitalist firms and further overdetermines the master/servant contradiction. Thus the state is perpetually engaged in discerning how to balance the risk-aversion inherent in maintaining the stability of the banking system, with the desires of commercial banks to enhance their profitability, possibly via the pursuit of activities associated with increased risk. 
In the event of a serious threat to the stability of the commercial banking system, the state is legally empowered to take certain actions designed to prevent bank panics. For example, the state, via its central bank, may act as "lender of last resort" to commercial banks to prevent a banking panic. Since the central bank stands ready to supply funds to commercial banks in crisis, depositors are dissuaded from instigating bank runs. Access to lender of last resort support further distinguishes commercial banks from other financial capitalist firms, since no other type of financial capitalist firm enjoys a legally enshrined mechanism of state support in the event of a crisis. ${ }^{20}$ Thus lender of last resort support overdetermines the subsumed class struggle among financial capitalists, in that it constitutes a competitive advantage of commercial banks over their non-bank financial capitalist competitors.

From the point of view of the state, the regulation and support of commercial banks is intended to reduce the vulnerability of the commercial banking system to crisis. But ironically, the existence of state support in the event of crisis may induce commercial banks to increase the risks they take and thus increase the possibility of inducing a crisis among commercial banks. Comforted by the possibility of lender of last resort support, commercial banks may migrate towards taking more risk in hopes of enhancing their profitability if risky activities succeed, while they hope to be assisted by the state if these risky activities fail. Thus banking regulators face a perpetual contradiction which is inherent in the principal agent relationship between banks and the state. The state is

\footnotetext{
${ }^{20}$ Of course, many capitalist enterprises (including non-commercial bank financial capitalist firms) may receive state support when they face a crisis. But it is rare that a private capitalist firm has access to an explicitly acknowledged and formalized mechanism through which an agency of the government (the central bank) provides liquidity in times of crisis.
} 
obliged to stand ready to assist commercial banks to avoid the possibility of widespread banking crisis, but the possibility of this assistance has the unintended consequence that it may induce commercial bank behavior that may provoke commercial banking crisis. This "moral hazard" contradiction implies that the particular principal agent relationship between commercial banks and the state has the perverse result of creating incentives that encourage behavior on the part of commercial banks that the state seeks to avoid.

The principal agent relationship between commercial banks and the state creates the possibility, but not the necessity, that the state will intervene to prevent a commercial banking crisis. Banking regulators exercise discretion in their decision to offer assistance in the event of a commercial bank crisis. Regulators may let commercial banks fail, especially when they judge that a particular commercial bank failure will not have unduly damaging ramifications for the commercial banking system as a whole. Thus the decision to intervene to avert or moderate any given commercial banking crisis is overdetermined by many factors as banking regulators consider the multiple implications (the number of commercial banks involved, the geographic dispersion of commercial banks in crisis, the amount of deposits at risk, the makeup of the depositors who stand to be affected by bank failure, the economic climate in which the crisis erupts, etc.) before deciding whether to intervene in any given commercial banking crisis. Although the context of each particular commercial banking crisis is important in determining whether state authorities will provide assistance to avert crisis, in general the larger the potential crisis, the more likely it is that state assistance will be forthcoming. Ironically, prominent commercial banks that provoke very large crises may be more assured of state protection, for the very 
magnitude of the crisis that their failure might generate makes them "too big to fail". Thus the moral hazard dilemma implicit in state support for commercial banking may tend to predispose commercial banks to increase risk in ways that are most disruptive for the commercial banking system, since any commercial bank in crisis is more likely to receive support if their failure will provoke widespread crisis.

The moral hazard contradiction implicit in state support for the commercial banking system creates the possibility, but not the necessity, that commercial banks will migrate into increasingly risky behavior. Since commercial banks cannot be assured that the state will intervene in any given commercial bank crisis, each commercial bank must weigh the possible benefits of increasing the risk they assume against their assessment of the likelihood that state support will be forthcoming if the risky activity fails. Even if state support is forthcoming, a commercial bank in crisis will face costs in terms of the reputation of the bank and increased regulatory scrutiny (so-called "frown costs").

Moreover, an individual commercial bank that assumes risks that are appreciably higher than its competitors may be less likely to receive state support, both because it is perceived as pathological by regulators, and because it is likely that a crisis generated by an individual bank will not be of sufficient magnitude to compel the regulators to fear for the safety of the commercial banking system. ${ }^{21}$ Thus the moral hazard contradiction as it is considered in this dissertation is not emphasized for its encouragement of maverick

\footnotetext{
${ }^{21}$ Unless the individual bank in question is sufficiently large that it is deemed "too big to fail".
} 
behavior on the part of anomalous commercial banks. From the point of view of state regulators, the moral hazard problem is more ominous if it encourages commercial banks to migrate collectively towards more risky activities.

\section{Commercial Banking And The Diversified Financial Capitalist Firm}

The preceding analysis has assumed that commercial banking takes place exclusively in a financial capitalist firm called a commercial bank, and that such a firm engages in no other form of financial capitalist activity. This type of specialized commercial banking firm was recommended by generations of banking theorists in the $19^{\text {th }}$ and early $20^{\text {th }}$ century. Banking theorists held that the stability of the commercial banking system was best insured by preventing commercial banks from engaging in non-banking financial capitalist activity, especially activities associated with securities markets. Thus the term "commercial bank" was developed to refer to a financial capitalist firm that facilitated "commerce" by using deposits to fund self-liquidating short term loans made to support the "needs of trade" (d'Arista 1993, 63-64). ${ }^{22}$ A separate type of financial capitalist firm, the investment bank, was views as the appropriate financial capitalist firm to involve itself with the much more risky financial capitalist activity associated with dealing in securities 23 : "Recognized banking authorities [in England] consider[ed] investment

\footnotetext{
${ }^{22}$ Much of this lending took the form of bridging the time period between the sale of goods and the receipt of payment, or the facilitation of payment for international trade. Until the great depression, when medium term lending became more common on the part of commercial banks, this orientation of commercial banks towards short term lending remained in force. Thus commercial banks were often engaged in the provision of so-called "working capital", rather than the promotion of long term accumulation.

${ }^{23}$ As other types of financial capitalist activity have proliferated (associated with pension funds, mutual funds, the provision of insurance and so on) this principal has been extended to argue that commercial banks ought to be precluded from any financial capitalist activity other than commercial banking.
} 
banking an inherently risky and speculative venture and, for that reason, considered any dealings in stocks and bonds an improper business pursuit for financial institutions entrusted with the savings of the general public." (Perkins 1971, 485)

In order to appreciate the rationale for prohibiting commercial banks from engaging in investment banking activity, the class analysis of investment banking is briefly considered. An investment bank is somewhat distinctive among financial capitalist firms in that it facilitates the ability of productive capitalist firms to access money capital from third parties. Productive capitalist firms seeking an infusion of debt or equity capital may issue securities and sell them to a variety of financial capitalist firms (pension funds, insurance companies and so on) or to individuals and other entities. However, the issuing firm may prefer to obtain the assistance of an investment bank to reduce the risks and delays associated with selling its stock or bonds. ${ }^{24}$ Investment banks typically engage in securities underwriting, in which case the underwriter purchases the securities from the productive capitalist firm at a price below what the securities are expected to fetch when sold to the public. The productive capitalist firm receives its money capital initially from the securities underwriter, and the underwriter recovers this amount of value, plus additional value, by reselling the securities to the public. This differential between the buying and selling price of the securities is forthcoming in part because of conditions in

\footnotetext{
${ }^{24}$ For simplicity, we leave aside the possibility that investment banks underwrite securities of non-surplus value appropriating capitalist firms or the securities of non-capitalist surplus appropriating firms.
} 
securities markets, but also because the issuing firm sells the securities initially at a price below the expected market price. Since the underwriter expands value by buying low and selling high, this value inflow is considered a non-class revenue from capital gains. ${ }^{25}$

An investment bank is a financial capitalist firm that conducts securities underwriting, together with earning various commissions and fees for dealing in securities in both primary and secondary markets, (as well as earning revenues from the provision of advice on mergers and acquisitions, research to investors, supplying margin credit, storing securities for safekeeping and so on). While we will forgo a detailed class analysis of investment bank profitability, it is apparent that in many ways investment bank profitability is reliant on the likelihood of capital gains. In an environment in which capital gains are easily forthcoming, the demand for securities is stimulated and thus productive capitalist firms will be encouraged to select this means of accessing money capital. In addition, since securities underwriters bear a risk that they may not be able to sell securities to the public at a price higher than they acquired them, this risk is diminished in a climate in which capital gains are more easily forthcoming. Moreover, many of the other forms of income that an investment bank typically generates are indirectly connected to likelihood of achieving capital gains (for example, the

\footnotetext{
${ }^{25}$ Unfortunately, the non-class categorization of this revenue obscures the security underwriter's role in providing money capital to the productive capitalist firm. In a manner somewhat reminiscent of the class analysis of merchant capital, we can view this payment as coming from the productive capitalist firm, in the sense that it forgoes a portion of its inflow of money capital which instead is retained by the underwriter. However, even from this perspective, the payment for securities underwriting is not a subsumed class payment, in the sense that it the funds come from forgone inflows of money capital and not appropriated surplus value.
} 
commissions earned via facilitating trading on secondary securities markets and the degree of mergers and acquisition activity may all be enhanced in a context in which capital gains earnings are vigorous).

This close affiliation of investment bank profitability and capital gains made an important impression on theorists of commercial banking regulation. Since the existence of capital gains depends on the vagaries of securities markets, these revenues are subject to considerable volatility. In the time interval between the purchase of securities and their retail sale, the investment bank is particularly vulnerable to any change in market conditions that may reduce the market price of the securities it holds. If a commercial bank becomes involved in securities underwriting, and if that commercial bank uses its funds to carry inventories of securities, it is possible that changes in the value of the securities portfolio may undermine the solvency of the commercial bank. Given that commercial bank regulators seek to prevent commercial bank failures, they sought to shield the commercial banking system from disturbances emanating from securities markets by prohibiting commercial banks from engaging in investment banking.

While the prohibition on blending commercial banking with other financial capitalist activities is intended to support the stability of the commercial banking system, financial capitalists resent having to forgo the profit-enhancing aspects of diversified financial capitalist firms. Diversified financial capitalist firms can vary their revenue mix according to prevailing economic, political, or cultural conditions that may, in a given context, advantage one of the various financial capitalist activities over the others. 
Financial capitalist activity involves information costs, and a diversificd financial capitalist firm may be able to benefit by spreading these costs over multiple financial capitalist activities. The administration of bank accounts can give commercial banks informational advantages (such as details about the financial affairs of their depositor ${ }^{26}$ ) that may prove helpful in the conduct of other financial capitalist activity. In terms of the first moment of financial intermediation, diversified financial capitalist firms that gather funds in a variety of ways may benefit from this diversity. Since depository financial capitalist firms face the perpetual possibility of instant withdrawals of savings, they may wish to add insurance or pension activities to their firm, since savers tend to leave funds in these forms for long periods of time. Of course, there are disadvantages that accompany diversification. Financial capitalist firms that specialize in only one subset of financial capitalist activities may acquire specific expertise or other advantages that is more diluted in diversified firms. Diversified financial capitalist firms are exposed to the crises that erupt in any form of financial capitalist activity. Thus a diversified financial capitalist firm is obliged to be vigilant lest a crisis in one aspect of its activities compromise the entire firm.

There are some distinctive advantages to blending of commercial banking and investment banking in a diversified financial capitalist firm. The capacity to make loans often assists the ability of an investment bank to attract underwriting revenue, since it

\footnotetext{
${ }^{26}$ Lenin remarks that by having access to the confidential transactions information of the bank's clients, the financial capitalist firm gains informational advantages: "the running of a current account for a given firm enables the bank - and this is what happens - to obtain fuller and more detailed information about the economic position of its client, the result is that the productive capitalist becomes more completely dependent on the bank." (Lenin 1975,45) Thus these informational advantages may assist financial capitalist firms in their subsumed class struggle with productive capitalist firms.
} 
enables the financial capitalist firm to provide debt financing in the period before a productive capitalist firm is able to issue securities. In their eagemess to participate in future lucrative investment banking revenues, a diversified financial capitalist firm may even be enticed to make questionable loans. Conversely, a commercial bank that finds itself with loans at high risk of default may be able to use the underwriting capabilities elsewhere in the diversified financial capitalist firm to enable its problem borrowers to issue securities and thereby repay the troubled bank loans. Such synergies between commercial banking and investment banking are made more compelling by the existence of lender of last resort support for commercial banking. Given the moral hazard dilemma implicit in lender of last resort support, commercial banks may migrate to riskier lending opportunities, particularly those connected with securities, if they are comforted with the possibility of lender of last resort support. While lender of last resort is intended to apply to only commercial banking activity, it is possible that a diversified financial capitalist firm may impose upon these supports to assist them in the event of a non-commercial banking crisis. During the tumultuous unfolding of a crisis in financial capitalist activity, a diversified firm may succeed in misrepresenting a non-commercial banking crisis as one emanating from commercial banking activities, or regulators may judge that the implications of a crisis in the non-commercial banking aspects of a diversified financial capitalist firm are likely to provoke a crisis in the commercial banking system. The possibility that a diversified financial capitalist firm may access lender of last resort support via its commercial banking arm can enhance the perceived security of the diversified financial capitalist firm as a whole, thus reducing costs for the diversified financial capitalist firm in its non-commercial banking activities. 


\section{The Diversified Financial Capitalist Firm And The Keynesian Agenda For Financial Reform}

From a class analytic point of view, the Keynesian agenda to make financial capital the servant of productive capital may be at odds with the organization of financial capitalist activity within diversified financial capitalist firms. If a diversified financial capitalist firm is sufficiently large, it may enjoy a degree of monopsonistic power over the access to savings, and/or a degree of monopoly power over the provision of funds to productive capitalist firms. In a situation characterized by a small number of large diversified financial capitalist firms that enjoy considerable market power, financial capital may be able to shift the subsumed class struggle between productive and financial capital to the detriment of productive capital. Thanks to their domination of access to money capital generally, a few large diversified financial firms may be in a position to extract a higher subsumed class payment for assess to both debt and equity capital. ${ }^{27}$ This outcome is precisely the opposite of that desired by Keynesian financial reformers.

Within the Marxian tradition, Hilferding considered the possibility that financial capitalist firms might dominate productive capitalist firms by virtue of their market power in the second moment of financial intermediation. His Finance Capital described conditions in which large and diversified financial capitalist firms grew to dominate productive capitalist firms that were facing an acute need for large inflows of money

\footnotetext{
${ }^{27}$ Of course, such a situation also carries with it its own negation. To the degree that a group of financial capitalist firms may hold market power in these respects, the incentive exists for new financial capitalist firms to enter in order to compete away this advantage.
} 
capital. ${ }^{28}$ While the sources of funds were arguably not so diverse as they are today ${ }^{29}$, the financial capitalist firms in Hilferding's day were able to both provide loans and purchase shares. ${ }^{30}$ To the extent that these large financial capitalist firms were able to parlay their position as the gatekeepers to money capital into a position of dominance vis à vis productive capital, they were in a position to demand high subsumed class payment for access to money capital. ${ }^{31}$

In the United States, Hilferding's concept of finance capital found its expression in the financial enterprises described as the "money trust". These diversified financial capitalist firms, epitomized by J.P. Morgan and Company, blended debt and equity capital provision. The House of Morgan was one of the leading investment banks that had supported the development of the railroads ${ }^{32}$, and the Morgan empire grew to have

\footnotetext{
${ }^{28}$ Hilferding argued that years of bitter competitive struggles and vigorous technological change produced a rapid concentration of capital in Germany at that time. The creation of cartels shielded productive capitalist firms somewhat from this ruinous competition, but these mergers and acquisitions required large infusions of money capital. Faced with these exorbitant financing demands, productive capital became increasingly reliant on financial capitalist firms, particularly large banks, while at the same time financial capitalist firms became increasingly concentrated in order to mobilize more financial resources.

${ }^{29}$ Many of the vehicles in which savings are held today, such as pension funds, mutual funds and even the widespread use of insurance were not present in the early part of the 20 th century.

${ }^{30}$ At this time, the lack of a well-developed stock market meant that finance capital often acted as shareholders in these productive capitalist firms rather than as underwriters that sold stock in these productive capitalist firms to a third party.

${ }^{31}$ Another possibility that Hilferding considers is that finance capital constitutes not just the ascendancy of productive capital over financial capital, but the merger of the two under the dominance of financial capital. For example, he considers circumstances in which financial capital is able to demand seats on the board of directors of the productive capitalist firms and exerts profound control over its distribution of surplus value.

${ }^{32}$ Morgan's investment banking activity originally took the form of underwriting securities to select group of European investors, rather than acting as underwriters for public offerings made widely available. In addition, Morgan used its own funds to buy and hold securities. Hence Morgan's activities represent an older form of investment banking that gave way to new types of investment banking in the 1920s that were engaged in underwriting securities for wider distribution.
} 
significant influence in commercial banking. ${ }^{33}$ Morgan parlayed its extensive stock

ownership and loan portfolio into 72 directorships in 47 of the largest US corporations, and thereby exerted considerable influence over both the path of development of productive capital $^{34}$ and on the determination of the subsumed class payments reverting to Morgan and Company. Money trusts were an increasing object of public hostility, as was evidenced in the 1912 Pujo commission analysis that money trusts constituted:

... a community of interests between a few leaders of finance, created and held together through stock ownership, interlocking directorates, partnerships and joint account transactions, and other forms of domination over banks, trust companies, railroads and public searches and industrial corporations, which has resulted in great and rapidly growing concentration of the control of money and credit in the hands of these few men. (in Meerschwam 1987,68)

In addition to the possibility that diversified financial capitalist firms may exert upward pressure on the subsumed class payment required to secure money capital in direct opposition to the Keynesian agenda for a "servant" relationship of financial capital to productive capital, Keynesians have additional reasons to disapprove of diversified financial conglomerates. To the extent that diversified financial capitalist firms blend commercial and investment banking, commercial banking may become increasingly animated by concerns related to securities markets. For example, it may be that the earnings related to the pursuit of capital gains within a diversified financial capitalist firm

\footnotetext{
${ }^{33}$ The House of Morgan did not necessarily operate as a commercial bank. At that historical time, personal relationships and informal agreements were often sufficient to create alliances between Morgan and commercial banks. The partners of J.P. Morgan and Company owned stock (directly or indirectly) and/or had interlocking directorships in many large banks, trust companies, insurance companies and savings banks. In this manner, Morgan's was aligned with the First National Bank of New York, and by 1912 , Morgan and Company and the First National Bank of New York controlled Banker's Trust, Guarantee Trust and the National Bank of Commerce. (see Kotz 1978, 36-37)

${ }^{34}$ When the money trust was investigated by the Pujo Committee in 1912, they found that "tightly held bank control had been instrumental in bringing about large corporate mergers at the turn of the century and that these mergers had resulted in furthering the strength of the bank's responsible for bringing these about."(de
} 
overshadows the commercial banking revenues earned by providing loans. In this event, the commercial banking system may become increasingly organized to facilitate capital gains rather than lending money capital.

To the extent that diversified financial capitalist firms create opportunities for commercial banking to become increasingly oriented to the promotion of speculation, the diversified financial capitalist firm is an anathema from a Keynesian point of view. Such a situation threatens to harness the deposit base of the economy towards the pursuit of capital gains. Worse still, given the unique institutional characteristics of commercial banking, any crisis that follows a period of speculative excess may be intensified if the activities undertaken during the period of vigorous speculation compromise commercial bank solvency. As subsequent chapters point out, difficulties associated with the crash of the stock market in 1929 put additional pressure on the commercial banking system, in part because commercial banking activity had become increasingly oriented towards the needs of the securities markets in the context of diversified financial capitalist firms.

Saint Phalle 1985, 52) In particular, Morgan's is credited with encouraging the consolidation of the railroads and the promotion of the mergers that produced General Electric and United States Steel. 


\section{CHAPTER 4}

\section{THE RISE AND SUBSEQUENT REPUDIATION OF THE DIVERSIFIED FINANCIAL CAPITALIST FIRM IN THE 1920s AND EARLY 1930s}

\section{Introduction}

During the 1920s, the organization of financial capitalist firms underwent dramatic transformation as commercial banks created diversified financial capitalist firms that branched into investment banking. While many factors shaped the development of these new diversified financial capitalist firms, chapter four will focus on two particular subsumed class pressures that contributed to this phenomenon. First, the pressure of competitive struggles among commercial banks in a crowded commercial banking sector compelled commercial banks to search for value expansion outside of traditional commercial banking. Secondly, the intensification of subsumed class struggle between commercial and investment banks in the context of the flourishing stock market provoked commercial banks to search out ways of earning revenues connected with investment banking. These subsumed class conditions interacted to compel commercial banks to expand into investment banking, and by 1927 significant legal barriers to the blending of commercial and investment banking within a diversified financial capitalist firm were removed.

The current chapter discusses these subsumed class struggles among financial capitalists that contributed to the development of diversified financial capitalist firms during this time period, and explores some of the ramifications of the development of 
these diversified financial capitalist firms on the subsumed class struggle between productive and financial capital. Because the development of these diversified financial capitalist firms coincided with the acceleration of the stock market boom in the later 1920s, the chapter considers how the blending of commercial and investment banking within diversified financial capitalist firms in this historical context had implications for commercial bank solvency during the great depression. By the time of the Roosevelt presidency, recurring commercial banking crises represented a debilitating obstacle for economic recovery. Thus because of their association with speculative excesses that had compromised the stability of financial intermediation in the United States, the architects of New Deal financial reforms came to regard the abolition of these diversified financial capitalist firms as a prerequisite for the Keynesian agenda for economic stability and growth.

\section{Competition in Commercial Banking: The Legacy of "Free Banking"}

One of the distinctive aspects of commercial banking in the United States has been the relatively large numbers of commercial banks in operation. This profusion of commercial banks was, in part, a reaction against the bank chartering process of the late 1700 s and early 1800 s. At that time a special legislative act was required to enable a firm to engage in commercial banking. This element of discretion afforded officials the opportunity to grant entry into commercial banking in return for financial or political favors. Strenuous arguments were made to " destroy ... the odious features of bank monopoly"'(in Klebaner 1990,13) by attenuating the ability of officials to manipulate the right of entry into commercial banking. Critics of this chartering system embraced "free 
banking", meaning the ability of any firm to enter commercial banking so long as it satisfied certain general conditions that were uniformly applied to all market entrants. In 1838, the state of New York passed the Free Banking Act, and ultimately the principle of free banking was enshrined by many states and in the National Banking Act of 1863. Until free banking was officially abandoned by New Deal financial reforms, this policy of relative ease of entry into commercial banking helped to create the large number of commercial banking firms that has characterized US commercial banking (see Figure 7). However, free banking often was accompanied by low initial capital requirements in order to encourage market entry. Thus free banking also contributed to the proliferation of commercial banks of dubious solvency and notorious banking practices. ${ }^{1}$

\footnotetext{
${ }^{1}$ Following the adoption of free banking, many small banks emerged that were engaged in all sorts of unsound and fraudulent banking practices. As Hammond describes "Notes were issued by banks with no known place of business, and no regular office hours; and kegs of nails with coin lying on top were moved overnight from 'bank' to 'bank' to show up as cash reserves just ahead of the bank examiners." $(1941,9)$ The term "wildcat" banking emerged in this period to describe the tendency of these dubious banks to locate their headquarters in rural areas.
} 
Figure 7: Numbers Of Commercial Banks Prior To The Great Depression Source: Banking Studies, 418.

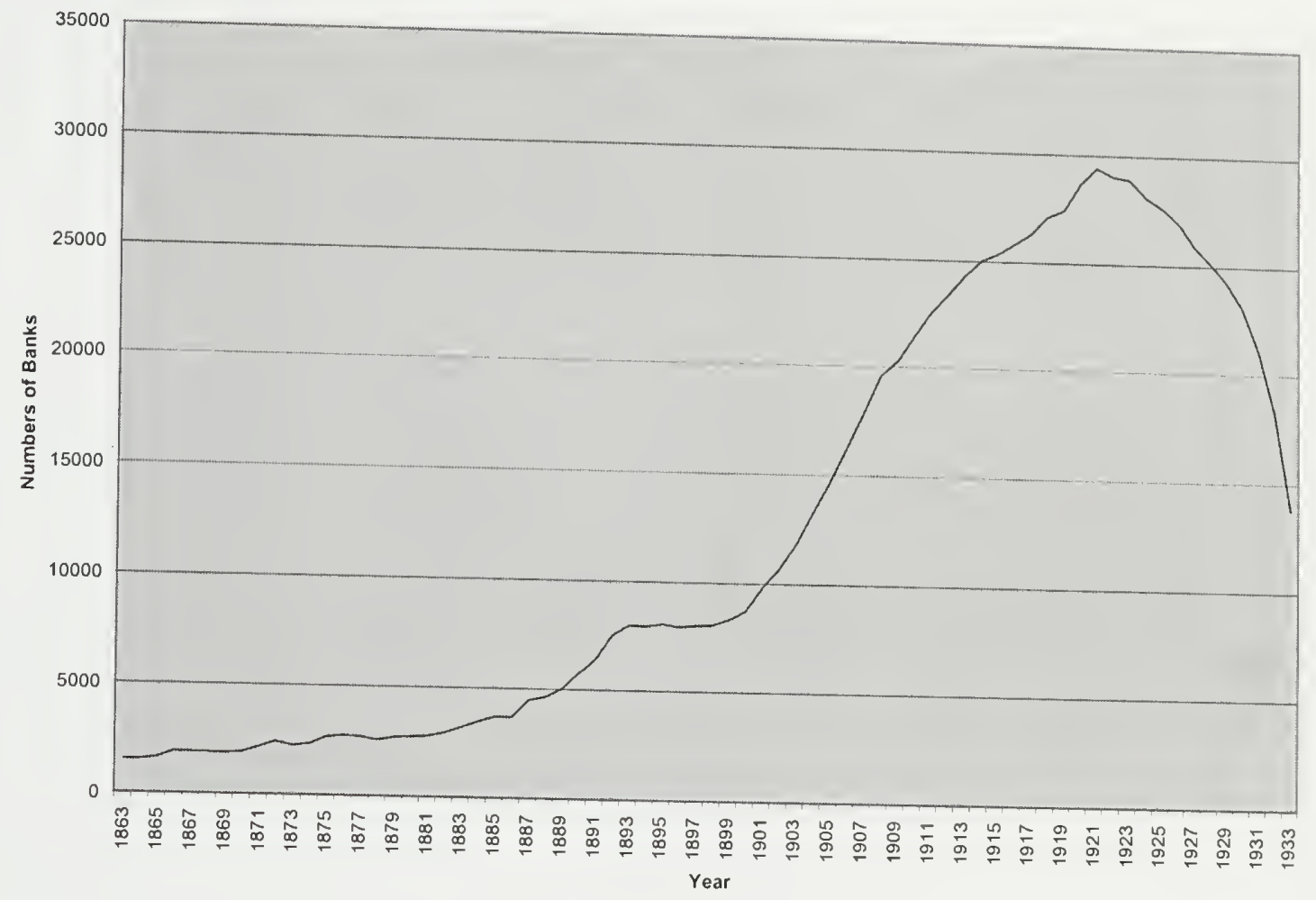

In addition to free banking, a number of regulatory peculiarities also promoted the large numbers of relatively leniently regulated commercial banks in the United States.

The United States has a dual banking system, in that commercial banks may be organized at the state or national level. This creates multiple regulatory structures, as the Office of the Comptroller of the Currency regulates national commercial banks, while various state authorities (and later the Federal Reserve to various extents over time) regulates state commercial banks. Under these circumstances, regulatory agencies compete with each other to charter and regulate commercial banks. This context of competitive chartering provides commercial banks the opportunity to threaten to change the jurisdiction in which 
they are chartered in order to compel regulators to match the permissiveness of rival jurisdictions. As Arthur Burns, former Chair of the Board of Governors of the Federal Reserve observed in a later context, multiple jurisdictions produced a "competition in laxity", among banking regulators. (in Sinkey 2002, 572) To the extent that regulatory competition and the dilution of regulatory standards facilitated new market entrants, this fragmented regulatory environment contributed to the proliferation of commercial banks. ${ }^{2}$ This competition in laxity also contributed to the questionable banking practices that culminated in the banking panics that were a familiar feature of the American finance prior to the New Deal. ${ }^{3}$

Between the turn of the century and 1920, the number of commercial banks accelerated rapidly until the total number of commercial banks reached a highpoint ${ }^{4}$ of 29,417 or a ratio of approximately one bank for every 3,500 Americans. (Klebaner $1990,124)$ In the face of this dramatic growth, the term "overbanking" was coined to refer to the intense competition in a crowded commercial banking market. ${ }^{5}$ In their retrospective examinations of events that contributed to the crisis in commercial banking

\footnotetext{
${ }^{2}$ For example, in the six months following the March 1900 decision of the Comptroller of the Currency to respond to pressure from nationally chartered commercial banks to reduce capital requirements for commercial banks in smaller communities (in order that they could compete with state chartered commercial banks in those communities), 509 new commercial banks were approved, which represents a $14 \%$ increase in the number of nationally chartered commercial banks. (Fischer 1968, 192 and author's calculation)

${ }^{3}$ After the passage of the National Banking act in 1863, there were four major banking panics $(1873,1884$, 1893, and 1907) as well as numerous regional and local panics.

${ }^{4}$ Bank failures, particularly in agricultural areas hard hit by depressed agricultural prices, as well as mergers and acquisitions among commercial banks, reduced the number of commercial banks during the 1920s.

${ }^{5}$ Of course the degree of competition among commercial banks varied in each state and even by city in jurisdictions where unit banking was enforced.
} 
during the great depression, many banking authorities became convinced that overbanking had resulted in excessive competition among commercial banks, which had both squeezed the profitability of commercial banks and enticed commercial banks to incur heightened risks to enhance their profitability. For example, state regulators in Indiana issued a report in 1932 that examined "indiscriminate" chartering, and they came to the "inescapable conclusion that many of the practices leading to bank failures were directly caused by cut-throat competition which sprang up in various communities as a result of too many banks". (in Fischer 1968, 207) The architects of New Deal financial reform were particularly persuaded that overbanking had contributed to the crisis in banking in the great depression. In 1938, J.F.T. O'Connor, a prominent financial regulator privy to the high level policy debates of the New Deal era ${ }^{6}$, produced an analysis of the banking crisis of the 1930 s in which he claimed that the ease of entry into commercial banking had created a precarious situation:

It was simple to be a banker. Charters were comparatively easy to obtain. With money necessary for initial capital, the depository money was anxious to find a resting place in return for the privilege of safekeeping and check drawing. Banks became too numerous; competition too great; necessity for profit too urgent. (O'Connor 1938, 7)

While data on commercial bank profitability is limited prior to the publication of the FDIC statistics on which this dissertation relies, some indications can be found that confirm that the period of overbanking in the 1920s was exerting pressure on commercial bank profitability. In the first moment of financial intermediation, fierce competition to

${ }^{6}$ O'Connor was Comptroller of the Currency between 1933-1938, as well as a member of the Federal Reserve Board between 1933-1935 and the first vice-chairman of the Federal Deposit Insurance Corporation. 
attract deposits can exert upward pressure on the $\mathrm{Y}$ costs associated with interest paid to depositors. Thus attracting a given volume of deposits is more expensive for a commercial bank, and its $\mathrm{Y}$ expenses associated with attracting deposits increases relative to its income earned. This trend is illustrated in Figure 8. This chart is prepared using information published by the Federal Reserve, and applies only to those commercial banks that were members of the Federal Reserve System during this time period. The numerator corresponds closely to our class analytic category of $Y$ expenses paid to attract deposits $^{7}$, however the denominator is only an approximation of the subsumed class and non-class revenue earned by making loans on the basis of deposits. ${ }^{8}$ Despite the difficulties in finding data that corresponds exactly to class analytic categories, Figure 8 illustrates a downward pressure on the profitability of Federal Reserve member banks to the extent that the expense of attracting deposits was increasing relative to earnings that those deposits help to produce in the second moment of financial intermediation.

\footnotetext{
${ }^{7}$ The numerator consists of interest paid on time deposits, interest paid on demand deposits, and interest paid on interbank deposits. The numerator excludes interest paid on borrowed money.

${ }^{8}$ Prior to 1927 , the Banking and Monetary Statistics did not distinguish between interest and discounts on loans versus interest and dividends on securities. Thus denominator used in Figure 8 overestimates the value of interest income on subsumed class and non-class loans, since it includes interest and dividends on securities.
} 

Figure 8: Interest Paid By Commercial Banks On Deposits As A Percentage Of Interest-
Related $^{9}$ Earnings From Loans And Securities

Source: Banking and Monetary Statistics, 262.

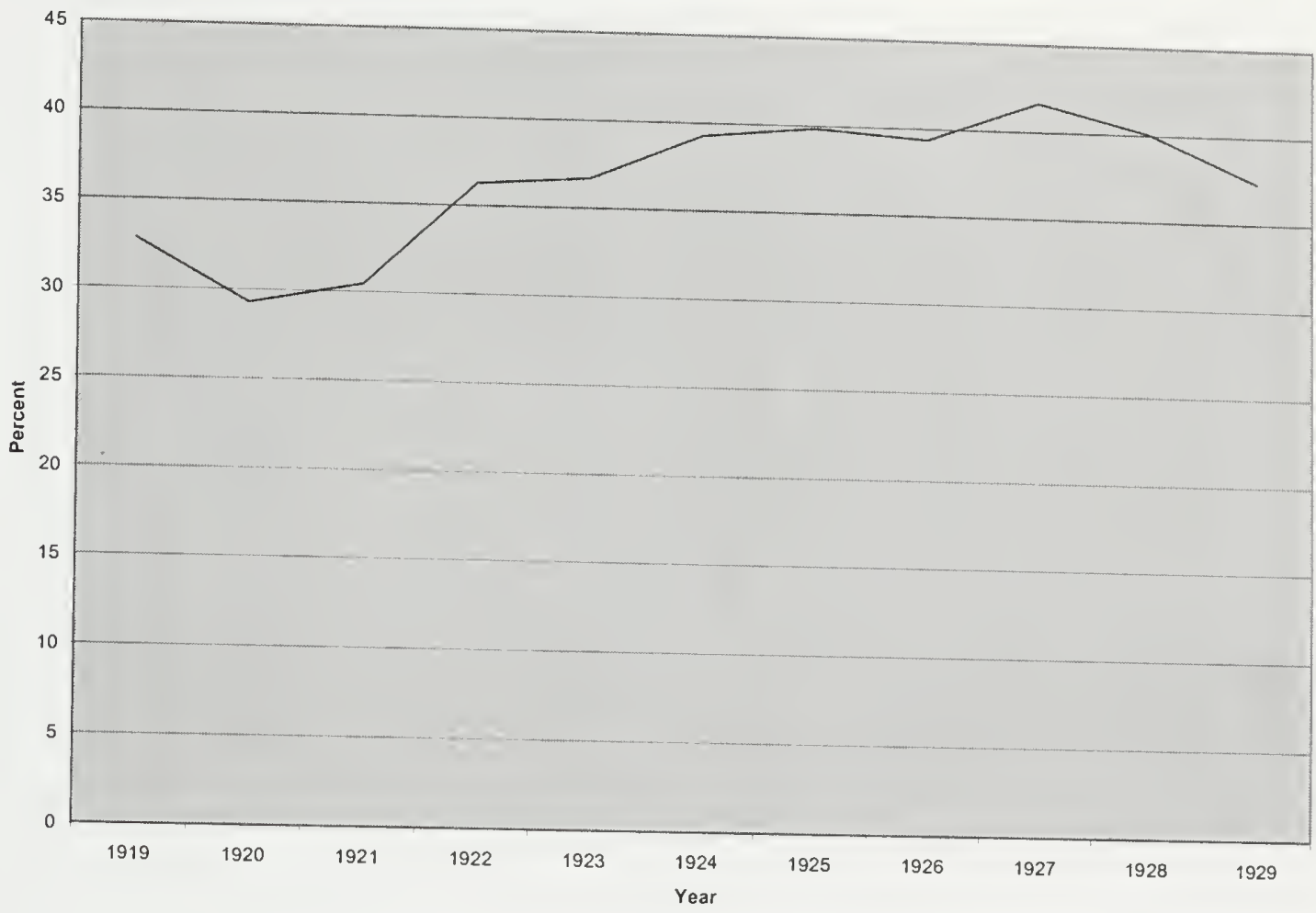

Vigorous competition among commercial banks also affects commercial bank profitability in the second moment of financial intermediation. As large numbers of commercial banks vie to provide loans, this intensified subsumed class struggle among commercial banks can result in downward pressure on the interest rate that banks are able to demand from borrowers. While interest rates are overdetermined by many factors, this downward pressure that subsumed class struggle among commercial banks exerts on the cost of securing loans is consistent with the behavior of interest rates charged by

\footnotetext{
${ }^{9}$ Specifically, the denominator consists of interest and discounts on loans plus interest and dividends on securities.
} 
commercial banks between 1920 and 1927. Figure 9 illustrates the behavior of the average interest rates that banks charged on loans to "customers" 10 of Federal Reserve member banks in leading cities during this time period.

Figure 9: Interest Charged on Customer Loans in Leading Cities Source: Banking and Monetary Statistics, 463.

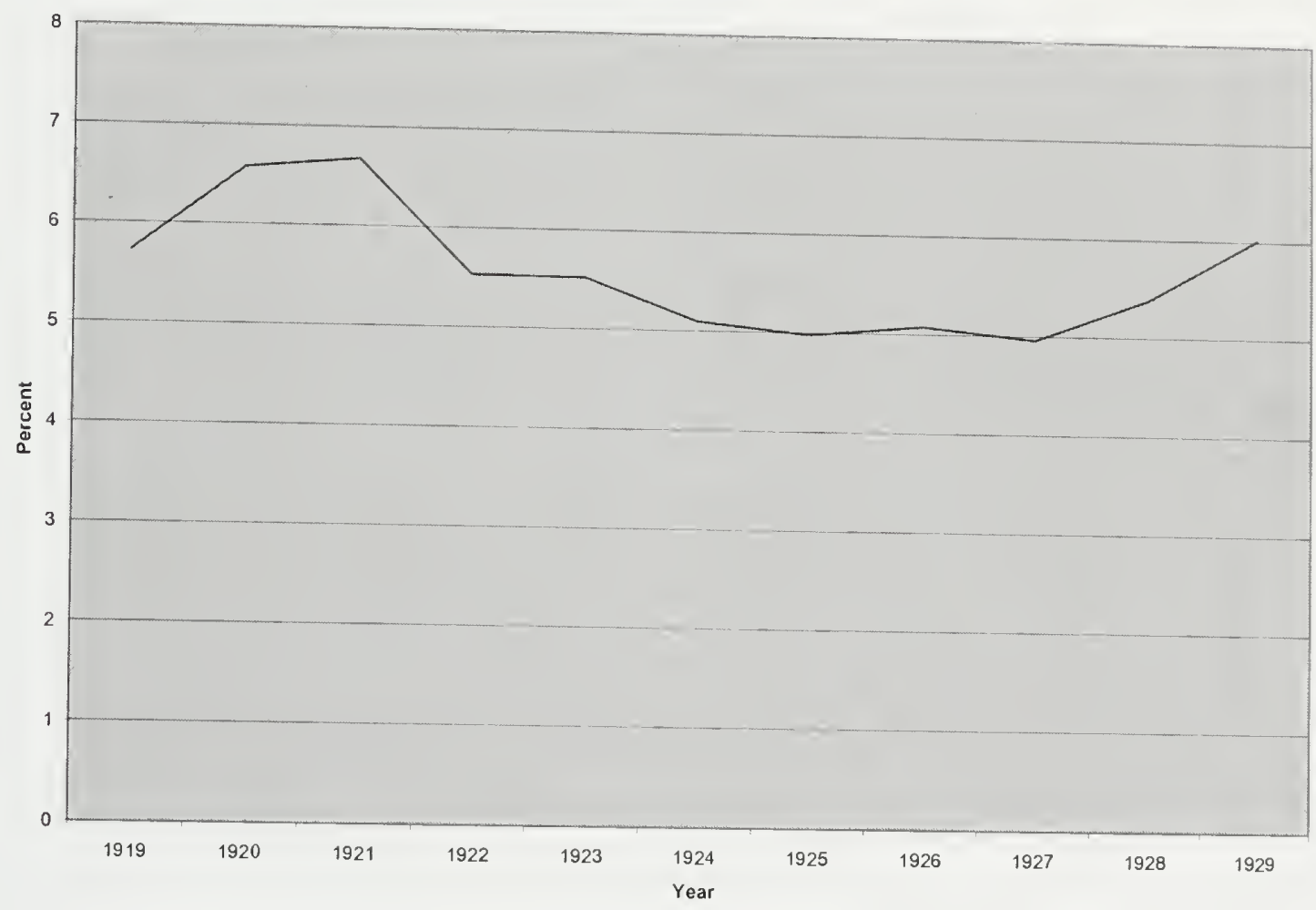

Thus overbanking intensified the subsumed class struggle among commercial banks both directly and indirectly. Intensified competition among commercial banks over the provision of loans constitutes increased pressure in the subsumed class struggle among commercial banks. In addition the increased competition to access deposits overdetermines the subsumed class struggle among commercial banks by augmenting the

\footnotetext{
${ }^{10}$ These "customer" loans are described as "commercial loans and time and demand security loans" in the notes provided on page 426 of the Banking and Monetary Statistics.
} 
costs of commercial banks in the first moment of financial intermediation. Since accessing funds in the first moment of financial intermediation is a condition of existence of earning subsumed class revenue, the competition over access to funds overdetermines the subsumed class struggle among commercial banks. Thus the intensity of competition facing commercial banks undermined commercial bank profitability in both moments of financial intermediation.

\section{Commercial Banking and the Stock Market Boom of the 1920s}

Alongside the phenomenon of overbanking, subsumed class struggles between commercial and investment banks were also being transformed by the rapid development of the stock market. With the conclusion of the first World War and the arrival of economic prosperity in the 1920 s, the US public became increasingly enthusiastic purchasers of securities. ${ }^{11}$ Corporate securities offerings mushroomed during the 1920 s (see Figure 10) as public offerings of securities gained in importance as a way for productive capitalist firms to raise money capital. This development provoked entry into financial capitalist activities that benefited from the opportunities associated with the booming stock market, and in particular there emerged a "mad scramble" (Edwards 1967, 230) to enter investment banking activities.

\footnotetext{
"The increased stock market participation of the US public is credited to various factors including the popularity of wartime Liberty bonds and the increasing availability of securities issued in smaller denominations. (see Carrosso 1970, 249-250) Carroso states that the total number of shares traded on the New York Stock Exchange grew from 227 million in 1920 to 1125 million by 1929.
} 
Figure 10: Corporate Securities Offerings, 1919-1941

Source: Banking and Monetary Statistics, 487.

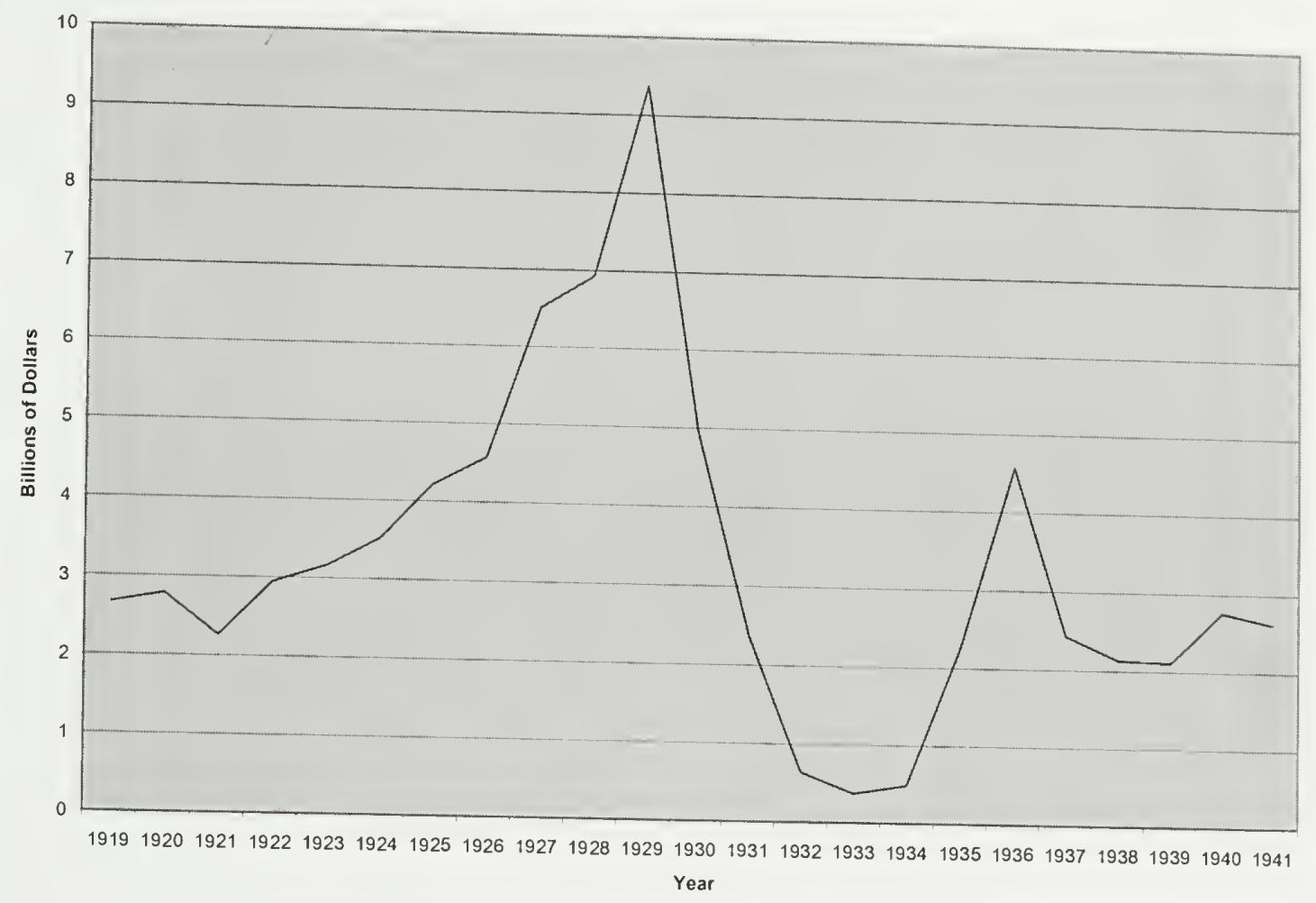

As productive capital made use of securities markets as new avenues to secure access to money capital during the 1920 s, commercial banks suffered. Despite the brisk demand for money capital during the economic growth of the 1920 s, many scholars claim that the demand for loans was undermined as productive capitalist firms found that they could secure money capital via the sale securities (d'Arista 1993, 64) or via retained carnings:

After 1919, corporations of all types, not just railroads and heavy industries, discovered an American public, now committed to the investing habit, were receptive to new securities issues of unprecedented frequency and dollar volume. As a consequence of this new access to the supply of long-term capital, many companies found they were far less reliant on banks to provide short-term, seasonal financing. In addition, high profits gave many corporations such a large cash flow that outside borrowing was unnecessary. (Perkins 1971, 493) 
Substantiation of this claim is somewhat sparse in the literature. Peach speaks to this issue by considering the declining importance of "commercial"12 loans among commercial bank assets. By examining annual reports of the Comptroller of the Currency, he finds that in 1920 commercial loans consisted of almost $60 \%$ of the total earning assets of nationally chartered commercial banks, while by 1925 this figure declined to about $45 \%$ and by 1930 it had stood near 35\%. (Peach 1941, 23-24) An attempt to illustrate the degree to which securities issues vied with commercial bank loans as a means of productive capital firms accessing money capital is made in Figure 11. Ideally, a comparison of the dollar volume of securities issued by productive capitalist firms with the dollar volume of loans advanced to productive capitalist firms would illustrate the relative importance of loans versus securities issuance as sources of money capital. The former category, securities issued by productive capitalist firms, is approximated in Figure 10. ${ }^{13}$ However, assessing the dollar volume of commercial bank loans to productive capitalist firms over this period is highly problematic. Thus we will refer only to loans advanced by Federal Reserve member banks for purposes unconnected with dealings in securities. ${ }^{14}$ Figure 11 provides the comparison between the dollar

\footnotetext{
${ }^{12}$ I have not been able to get clarification as to the definition of a "commercial " loan in statistics prepared by the Comptroller of the Currency during the period.

${ }^{13}$ It consists of all corporate securities issued, thus it will include some securities issued by unproductive capitalist firms.

${ }^{14}$ The first difficulty is that data provided by the Federal Reserve does not include commercial bank loans by banks that were not members of the Federal Reserve system during this period, and thereby underestimates the amount of loans made by all American commercial banks. Secondly, the attempt to assess the percentage of total loans made to productive capitalist firms is impossible. Information on the total amount of commercial bank loans is available, but this includes both loans made to productive and unproductive capitalist firms, to other entities, and loans made related to securities markets. The best approximation of loans made to productive capitalist firms is derived by taking the total loans made and subtracting loans connected to securities markets. The definition of loans made "on securities" also varies
} 
volume of security issues relative to the dollar volume of loans made by Federal Reserve member banks for purposes other than dealing in securities. As the dollar amount of securities issuance increased relative to the non-securities related loans made, this represents an increased reliance on securities markets and a decreased reliance on commercial banks as a source of funding.

Figure 11: Corporate Securities Issued vs. Commercial Bank Loans Unconnected to
Securities 15 Source: Banking and Monetary Statistics, 487, 132-163.

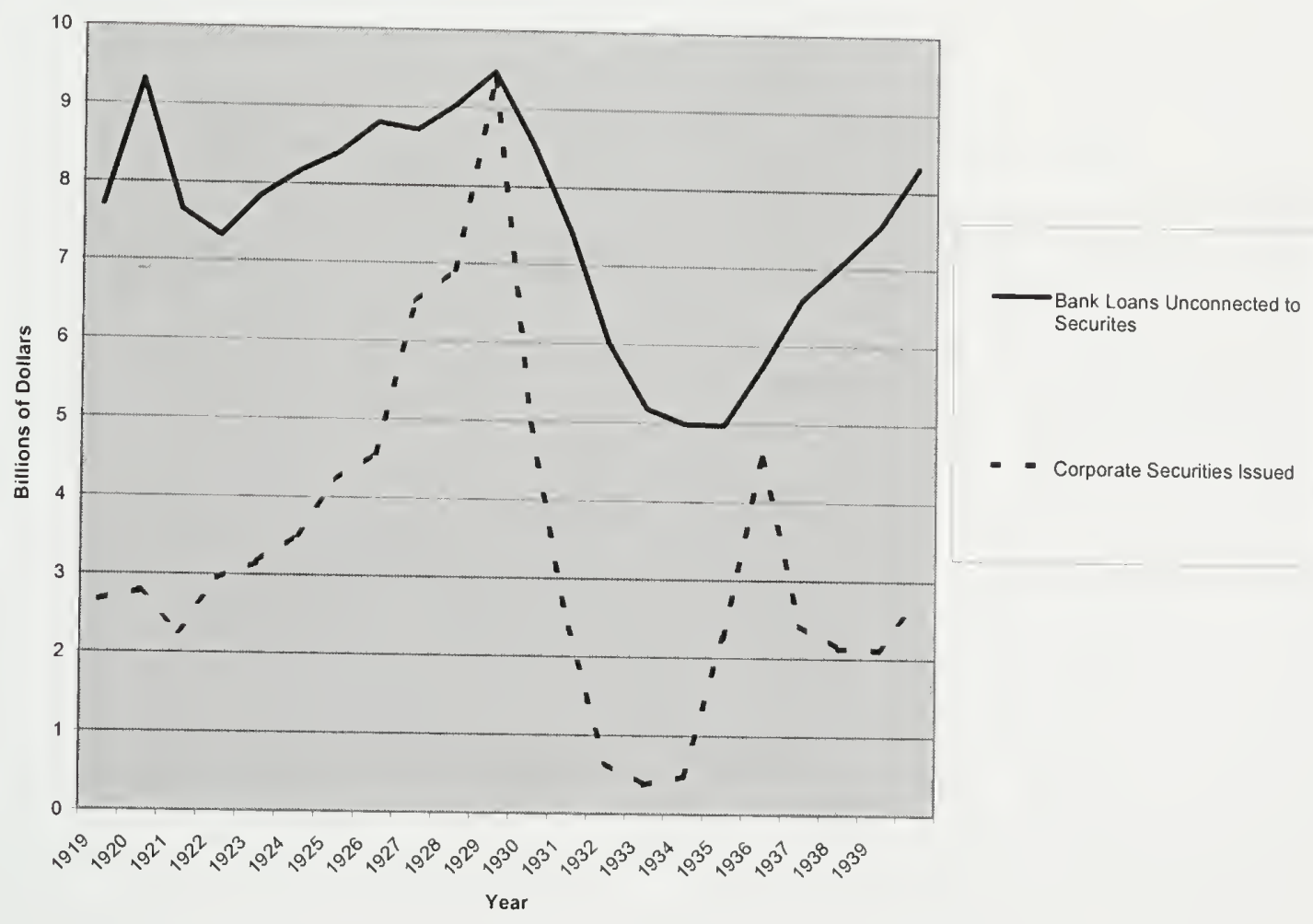

over the time during which this data was collected by the Federal Reserve (loans made "on securities are defined as "loans on stocks and bonds" between 1919 and 1928, defined as "loans to [securities] brokers and dealers" plus "[securities] loans to others" from 1929 to 1937 and defined as "loans for purchasing or carrying securities " until 1941). By presenting loans that were not categorized as being connected to securities market activities, this figure is an overestimate of the loans actually made to productive capitalist firms, since it will include non-class loans made to entities other than productive capitalist firms.

${ }^{15}$ This figure is prepared using yearly totals for corporate security issuance (487) and loans on the books of Federal Reserve member banks in 101 leading cities as of year end. (132-163) 
To the extent that securities issuance was displacing commercial bank loans as a preferred means of accessing money capital, this development represents an intensification of subsumed class struggle among financial capitalist firms. Assuming that debt capital provided by commercial banks is a close substitute to debt and equity capital garnered by issuing securities, the flourishing securities markets provide an opportunity for productive capital to pit commercial banks against investment banks as the avenues through which the money capital was provided to the capitalist fundamental class process. This intensified subsumed class struggle among financial capitalist firms exerts downward pressure on the subsumed class payment required to secure access to money capital generally, and in particular it squeezes the interest rate that commercial banks can command for their subsumed class loans to productive capitalist firms.

\section{Commercial Bank Expansion Into Diversified Financial Capitalist Firms In The Late 1920s}

The changing context of subsumed class struggles among financial capitalist in the 1920s exerted considerable pressure on commercial banks. The combination both competition among commercial banks and competition with investment banks helped to create subsumed class conditions that put pressure on commercial bank profitability. While the assessment of commercial bank profitability is difficult given the available data, Figure 12 illustrates this problem via the Return on Assets of Federal Reserve member banks between 1919-1929. 
Figure 12: Return on Assets of Federal Reserve Member Banks, 1919-1929

Source: Banking and Monetary Statistics, 263-4.

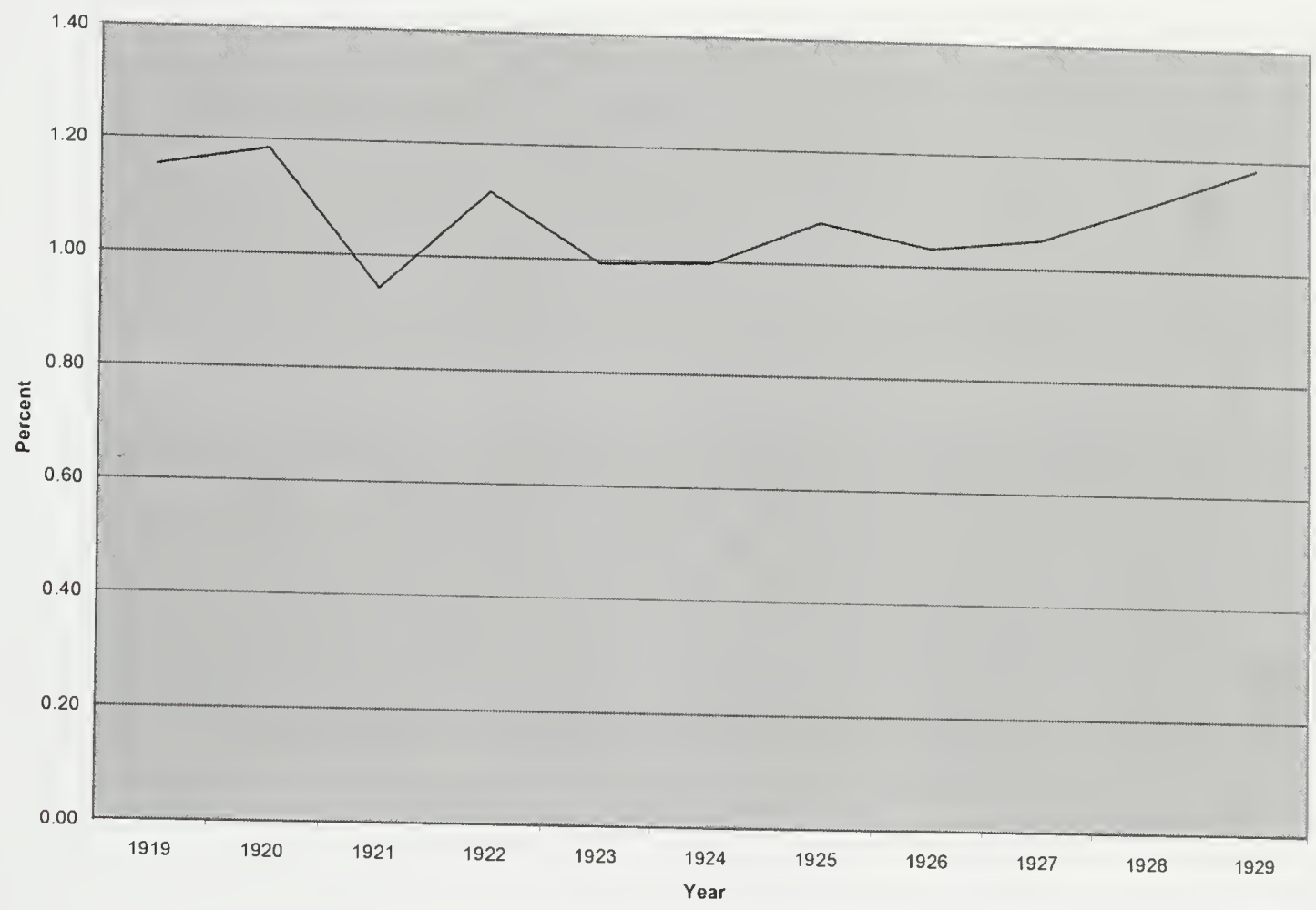

One of the ways that commercial banks responded to this pressure was by creating diversified financial capitalist firms that entered into investment banking activities. The creation of diversified financial capitalist firms responded to both the pressures of overbanking and the intensified subsumed class struggle between commercial and investment banks. In the context of an accelerating boom in the stock market, financial capitalist activity connected with securities markets was particularly lucrative. Thus commercial banks could respond to the pressures of overbanking by forming diversified financial capitalist firms that supplemented their profitability with investment banking revenues. Moreover, commercial banks that were being squeezed out of the provision of 
money capital by securities issuance had an opportunity to respond to this subsumed class struggle by entering the terrain of their financial capitalist rivals:

This decline in loan demand threatened the earning power of commercial banks and encouraged them to seek other opportunities for profit. An expansion of investment banking functions to offset the reduction in loan revenues was a course chosen by more and more large urban institutions. (Perkins 1971, 493)

Commercial banks had previously attempted to expand into securities underwriting via their bond departments, but these attempts were curtailed by the regulator of nationally chartered commercial banks, the Comptroller of the Currency. (Carosso 1970,97$)^{16}$ To circumvent these restrictions, commercial banks attempted to organize securities affiliates, however the growth of these security affiliates was constrained because of disputes about their legality and anti-trust concerns. By the mid 1920s many state jurisdictions were becoming increasingly permissive in allowing statechartered commercial banks to migrate into investment banking activities, but these activities were still prohibited for nationally chartered commercial banks. By 1927, large commercial banks successfully lobbied for the passage of the McFadden Act, which enabled nationally chartered banks to fully engage in securities underwriting via the creation of securities affiliates. The passage of the McFadden Act marked the full-scale regulatory embrace of diversified financial capitalist firms that blended commercial and investment banking. A surge of mergers among commercial banks and free-standing

\footnotetext{
${ }^{16}$ Kaufman and Mote claim, contra many authorities in the field, that the Comptroller of the Currency issued no formal ruling in 1902 specifically prohibiting nationally chartered commercial banks from dealing in securities. However, they claim that nationally chartered commercial banks could only engage in investment banking activities via the "incidental powers provision" of the National Bank act, while state chartered commercial banks often had explicit authorization to engage in investment banking. Thus the more permissive regulatory climate enjoyed by state chartered commercial banks enhanced their ability to engage in investment banking activities, and the Mcfadden act was demanded to equalize the status of national and state commercial banks in this respect. (Kaufman and Mote 1992)
} 
investment banks followed, and by 1929 nearly every large urban commercial bank had one or more securities affiliates. (Carosso 1970, 278) These new securities affiliates quickly grew to a formidable presence in the investment banking field. Peach illustrates this among nationally chartered commercial banks with respect to their mushrooming share of bond underwriting. He reports that commercial bank-related underwriters ${ }^{17}$ issued $22 \%$ of all new bonds in 1927 , while by 1929 , commercial bank-related underwriters had $45.5 \%$ of the share of total bond issues. (109)

These diversified financial capitalist firms, or "department store" banks as the business press of the day called them(Carosso 1970,276$)^{18}$, have the potential to reshape subsumed class conditions that were detrimental for commercial banks. If diversified financial capitalist firms could diminish competition among financial capitalist firms, this would attenuate the subsumed class struggle among financial capitalists that was injurious to commercial bank profitability. To the extent that this is possible, diversified financial capitalist firms would reshape the subsumed class struggle between productive and financial capital, since the ability of productive capital to benefit from competition among financial capitalist firms would be diminished. Thus in a manner reminiscent of finance capital, diversified financial capitalist firms offered the possibility that financial capital might gain the ascendancy over productive capital.

\footnotetext{
${ }^{17}$ Peach's actual terminology is "all national bank affiliates, commercial banks and trust companies".

${ }^{18}$ Department store" banks earned this nick-name in reference to their ability to meet all of its customers' needs. The term "department store banking "was mimicked in the 1990s, when advocates of a return to the blending of commercial banking and investment banking claimed that financial capitalist firms would provide a "financial supermarket" with the purported advantages of "one stop shopping".
} 
Diversified financial capitalist firms became fully legal in 1927, but their evolution was cut short by the devastating stock market crash in 1929. Thus it would be somewhat premature to conclude that the emergence of department store financial enterprises constitutes an unambiguous return blending of productive and financial capital reminiscent of the possibilities suggested in Hilferding's finance capital. The overdetermined context in which commercial banks created these diversified financial capitalist firms differed enormously from the context analyzed by Hilferding. For example, the possibility of relying on retained earnings, and the spectacular increase in stock market prices (which makes the acquisition of additional equity capital relatively easy), are factors which mitigated against the domination of productive capital by financial capital. However, to the extent that the organizational form of the diversified financial capitalist firm creates the possibility of maneuvering into a position of dominance vis à vis productive capital, this organizational form is an anathema to the Keynesian agenda for the servitude of financial capital.

As commercial banks became more attuned to stock market dynamics via their securities affiliates, this in turn overdetermined the risk profile of commercial bank lending. In the context of a stock market boom, there were many opportunities to engage in lending of dubious merits. Since commercial bank profitability had been experiencing pressure, the migration towards increased risk in lending portfolios is one way to enhance commercial bank profitability, particularly since a crowded commercial bank market and the relatively easy availability of money capital via securities issuance in the late $1920 \mathrm{~s}$ produced intensified competition for more conservative lending opportunities. Moreover, 
the organizational form of the diversified financial capitalist firm facilitated the opportunities for commercial banks to incur greater risks in their lending portfolios. For example, commercial banks could use their lending prowess to assist the clients of their investment banking affiliates to borrow money to fund their securities purchases. ${ }^{19}$ Figure 13 illustrates the degree to which commercial bank lending portfolios became increasingly oriented to securities-related lending as the 1920s wore on. When the stock market crashed, these loans were highly compromised, particularly in situations in which securities themselves had been presented as collateral for the initial loan. Thus the risks that commercial banks had assumed during the late 1920s increased the vulnerability of the commercial banking system to widespread banking failures.

\footnotetext{
${ }^{19}$ Even commercial banks that had no securities affiliates were not immune from involvement in lending related to the securities markets. Funds from smaller banks could often earn a higher interest rate when funneled to New York and lent on the call market than they could earn by making loans locally. This development was viewed in retrospect as pathological by New Deal financial reformers who regarded this behavior on the part of regional commercial banks was draining money capital from productive capitalist firms around the country.
} 
Figure 13: Commercial Bank Loans Made On Securities As A Percentage Of Total
Commercial Bank Loans ${ }^{20}$ Source: Banking and Monetary Statistics, 132-163.

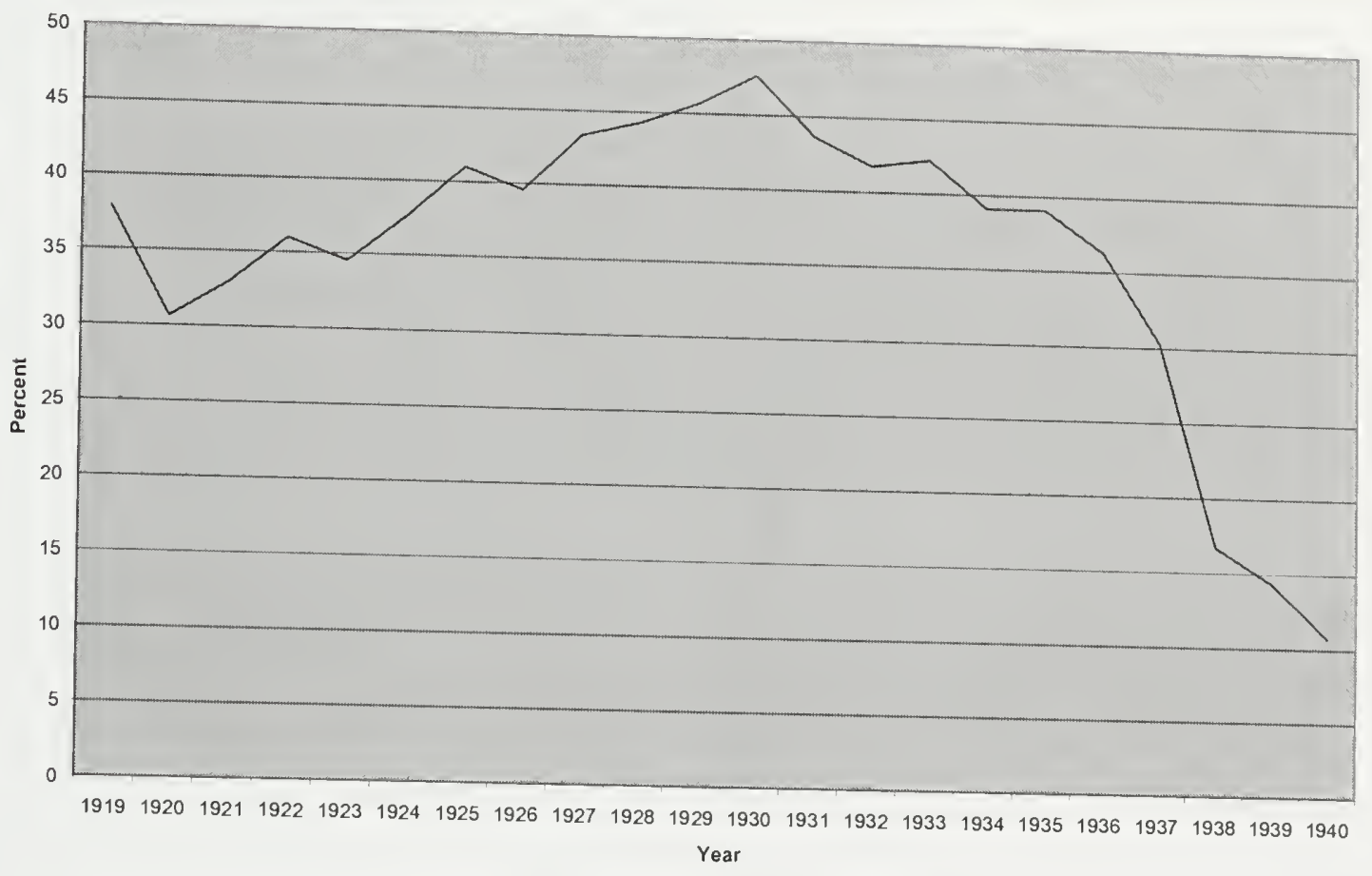

The Commercial Banking Crisis In The Early 1930s

The 1929 stock market crash and the persistence of the subsequent economic stagnation proved disastrous for commercial banks. Given that the loan portfolios of commercial banks were increasingly affected by the fortunes of the stock market, the precipitous drops in securities prices had important implications for commercial banking. Defaults on loans (especially those connected with securities), together with the devaluation of the collateral backing those loans (often the securities themselves), contributed to an acute crisis in commercial banking. Moreover, the great depression that

${ }^{20}$ All data from this source pertains to banks that are Federal Reserve System members. 
followed the stock market crash intensified the problems faced by commercial banks.

Defaults on loans unconnected to securities rose as general economic stagnation continued, and demand for new loans was slack, thus further preventing commercial banks from earning their way out of their difficulties. These disastrous circumstances culminated in an acute profitability crisis for commercial banks. While the Return on Assets hovered between $.99 \%$ and $1.19 \%$ throughout the $1920 \mathrm{~s}$, it had dipped to $-1.07 \%$ by 1933 (see Figure 14).

Figure 14: Return on Assets of Federal Reserve Member Banks 1929-39 Source: Banking and Monetary Statistics, 263-4.

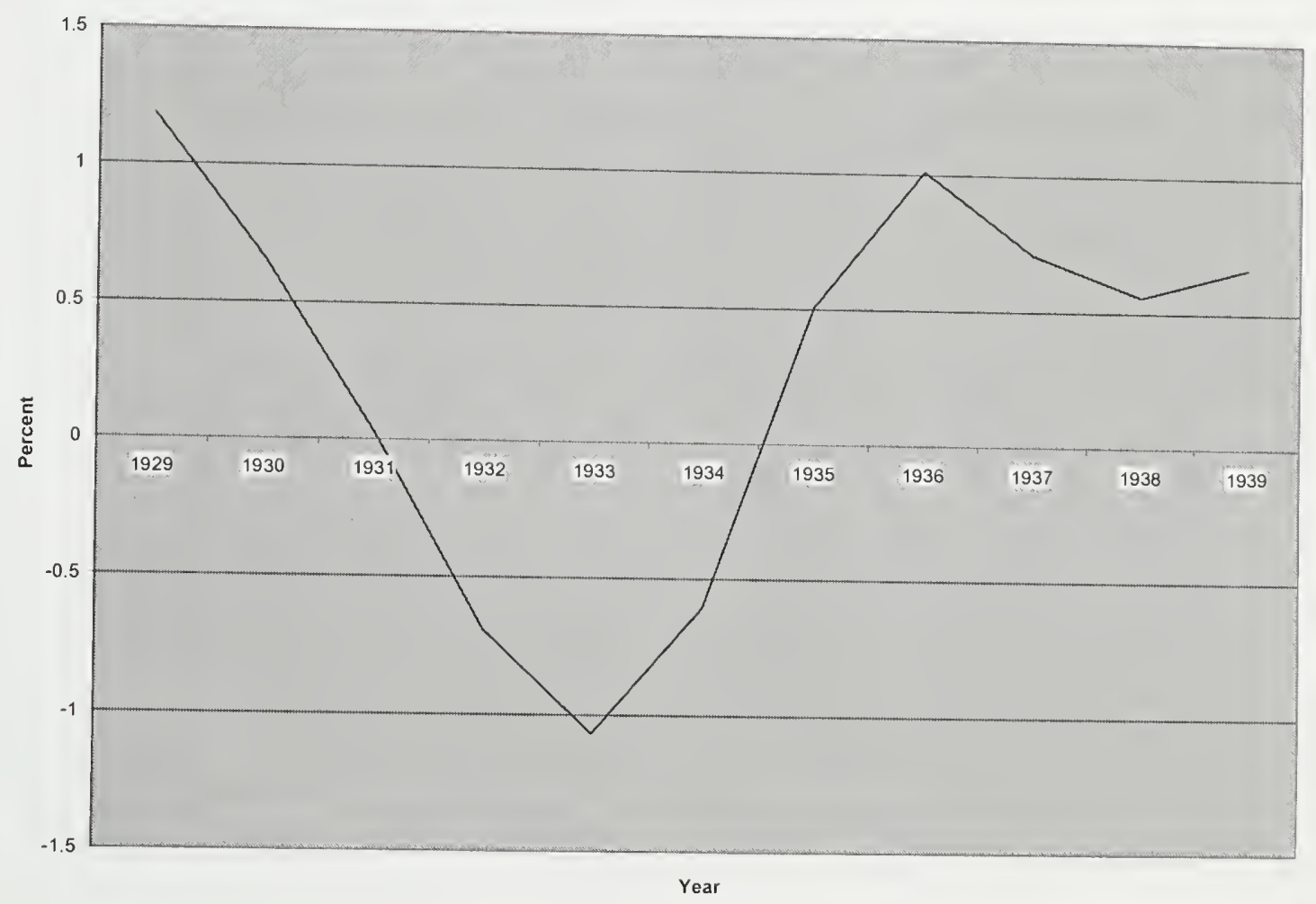

The crisis among commercial banks culminated in general breakdown in the process of financial intermediation, which in turn intensified the economic depression. A downward spiral was generated as depositor nervousness provoked bank runs, which in 
turn produced bank failures, which further undermined depositor confidence. State and nationally chartered commercial banks in operation dropped from 29,258 in 1929 to

15,021 by 1934 . As bank failures destroyed deposits ${ }^{21}$, this depressed the money supply, thus further exacerbating the economic downturn. In addition, the instability of the banking sector compromised transactions the economy, which further inflamed depositor panic. This process culminated in the decline in the deposit base of commercial banks until the passage of the New Deal financial reforms in 1933 (see Figure 15). In the midst of this cascading crisis in financial intermediation, surviving commercial banks increasingly began to hold excess reserves as protection against bank runs. This in turn further compromised the ability of commercial banks to act as a transmission mechanism for monetary policy. Despite attempts on the part of the Federal Reserve to increase the high powered money available in the banking system, the increased holdings of excess reserves had devastating impacts on the money multiplier. ${ }^{22}$

\footnotetext{
${ }^{21}$ About 7 billion in deposits were lost due to bank failures in the five year prior to the passage of the Glass-Steagall Act. (Compton 1987, 11)

${ }^{22}$ In the event that commercial banks hold excess reserves, the money multiplier is compromised, and additional high powered money provided by the Federal Reserve has reduced impact on the money supply. d'Arista notes the prevalence of this problem in 1932. (d'Arista 1993, 163) Friedman and Schwartz argue that from August of 1929 to March of 1933, the change in High powered-money should have produced a rise in the stock of money of $17.5 \%$. However, as the widely used formula for the money multiplier (see below) illustrates, a rise in the currency deposit ratio (reflecting withdrawals of currency from bank accounts) and a rise in the excess reserve to deposit ratio (reflecting increased commercial bank holding of excess reserves during a time of banking panics) produced a drop in the money stock of $35 \%$ despite the increase in high powered-money. (Friedman and Schwartz 1963, 332-333) money multiplier $=[1+\mathrm{c} / \mathrm{d}] /[\mathrm{rr}+\mathrm{er} / \mathrm{d}+\mathrm{c} / \mathrm{d}]$ where $\mathrm{c} / \mathrm{d}$ is currency deposit ratio, $\mathrm{rr}$ is the required reserve ratio and $\mathrm{er} / \mathrm{d}$ is the excess reserve deposit ratio
} 
Figure 15: Failures Of Federal Reserve Member Commercial Banks As A Percentage Of Total Federal Reserve Member Commercial Banks, 1919-1933

Source: Banking Studies, 418-419.

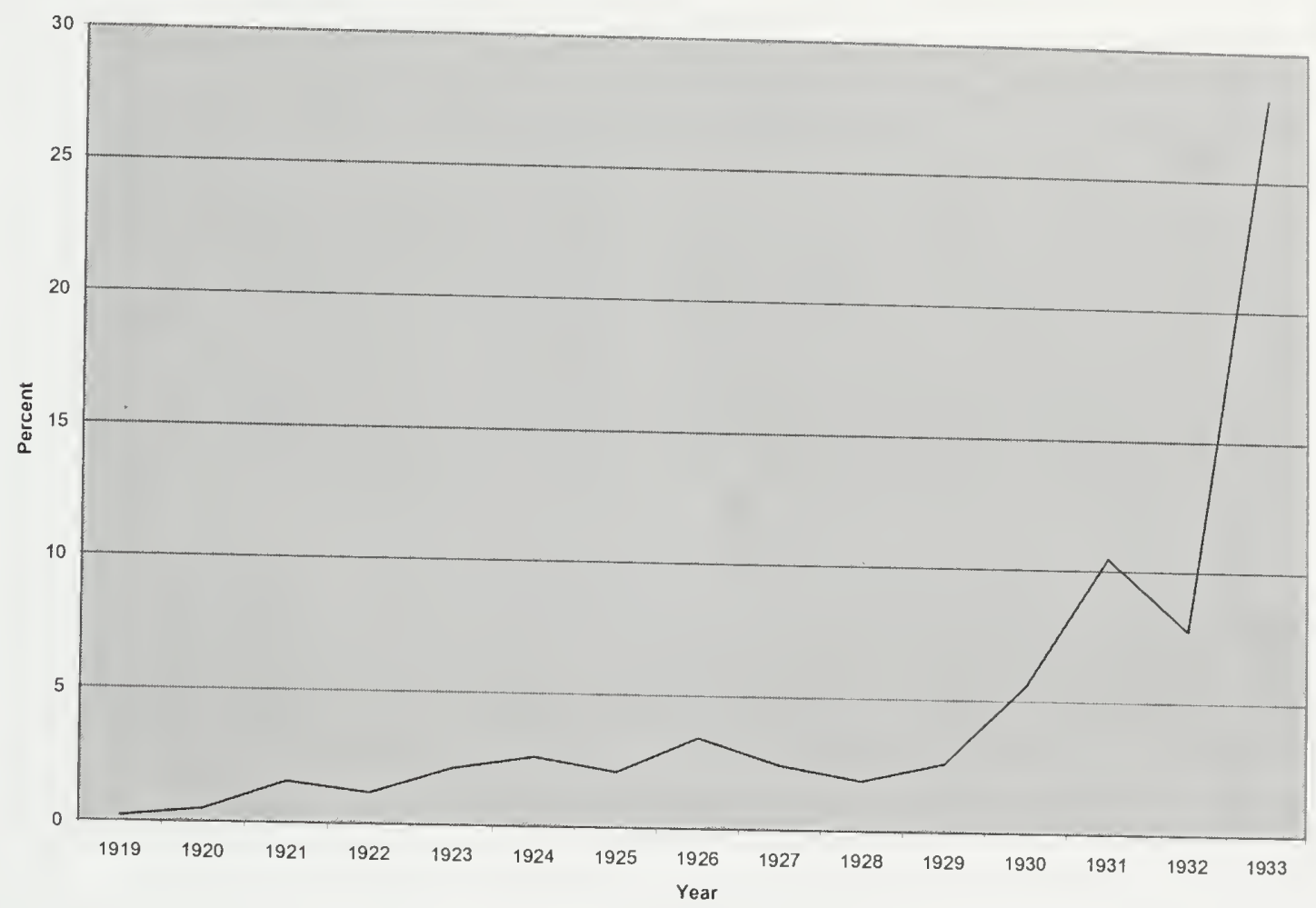


Figure 16: Bank Deposits, Federal Reserve Member Banks, 1920-1941

(deposits measured at year-end call date)

Source: Banking and Monetary Statistics, 72-75.

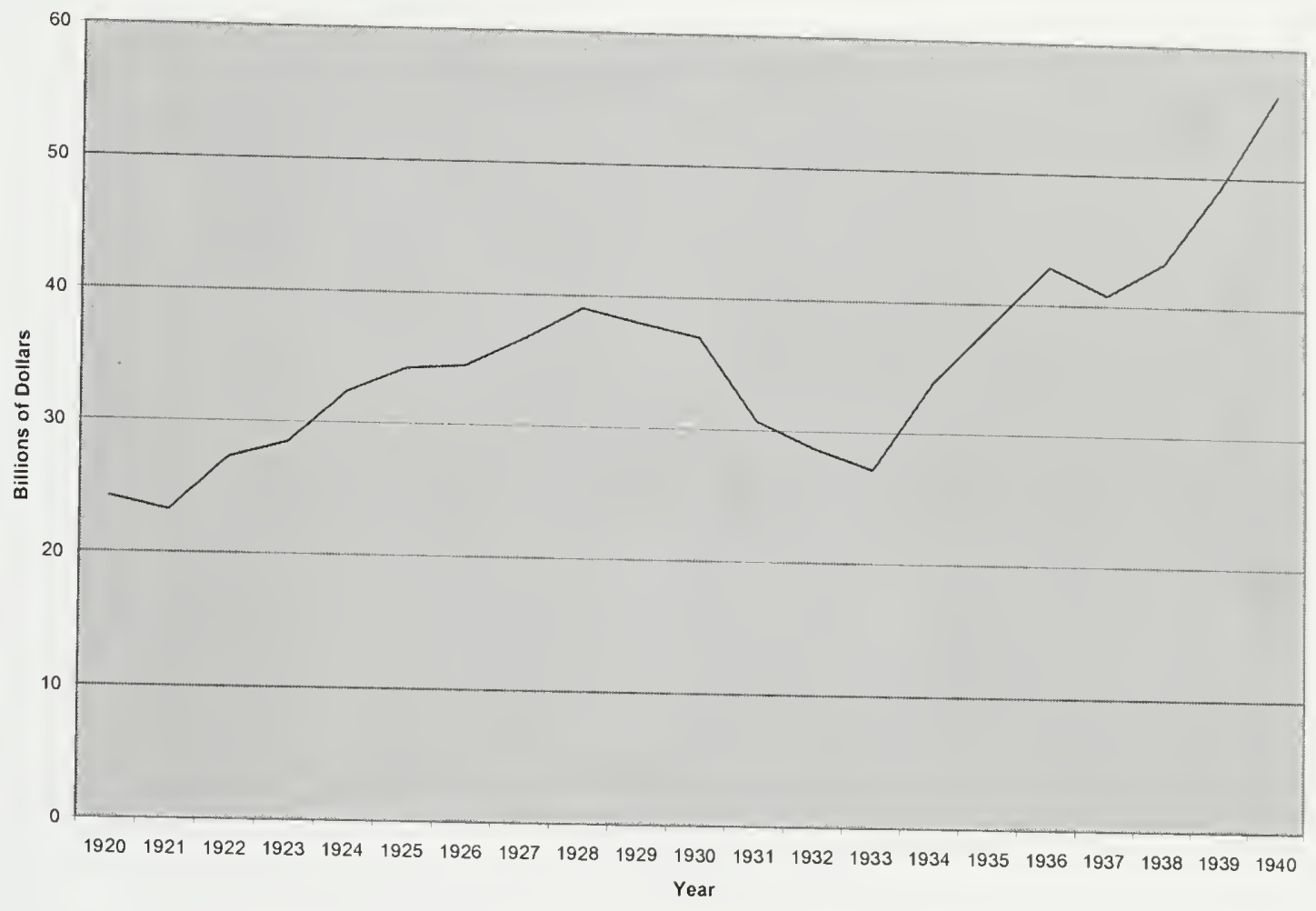

As this situation spiraled downward, the perverse implications of this crisis in commercial bank profitability mitigated against the use of expansionary monetary policy for other reasons. Before the Banking Act of 1933, commercial banks paid interest on demand deposits. This represented a serious burden to commercial banks at a time when substantial loan losses and a dearth of new lending opportunities made it difficult to earn revenues to pay interest to depositors. In response to this dilemma, and to enhance their liquidity in the event of banking panics, banks had increasingly shifted into holding shortterm government securities. By 1932, "investments" (mostly in government securities) comprised $50 \%$ of bank earning portfolios among members of the Federal Reserve 
System. (Epstein and Ferguson 1984, 969) The interest paid on these securities

represented a non-class revenue that enabled commercial banks to pay the interest owing on their demand deposits. However, this situation created an important obstacle to expansionary monetary policy. According to Epstein and Ferguson, the Federal Reserve briefly experimented with open market operations to increase the money supply, but the unintended result of this policy was to further squeeze bank profits by diminishing banks earnings on their government securities. ${ }^{23}$ Alarmed at this additional burden to their profits, commercial banks succeeded in pressuring the Federal Reserve to abandon expansionary monetary policy. Epstein and Ferguson argue that Keynes was aware of the desperate reliance of commercial banks on their earnings from government securities, and its perverse implications for monetary policy. They claim that it is for this reason that Keynes declared that "... in the United States the fear of the [Federal Reserve System] Member Banks lest they should be unable to cover their expenses is an obstacle to the adoption of a wholehearted cheap money policy."(in Epstein and Ferguson 1984, 957) 24

By early 1933 the commercial banking system was undeniably in profound disarray. Runs on commercial banks reached such epidemic proportions that it has been estimated that close to $10 \%$ of the nation's deposits were being withdrawn per week. (Klebaner

\footnotetext{
${ }^{23}$ Epstein and Ferguson state that rates on short term Treasury notes dropped from $3.4 \%$ in 1929 to $0.34 \%$. in 1932. $(1984,970)$ They claim that, as interest rates fell, commercial banks were unable to realize capital gains from these government securities because of the shortness of the banks' portfolios. (ibid.)

${ }^{24}$ Epstein and Ferguson conclude with a remark on the dilemma faced by the Federal Reserves because it must insure that the agents of monetary policy, commercial banks, must be profitable to operate in their capacity as the transmission mechanism of monetary policy: "As Keynes alone seems to have recognized, the capitalist organization of finance implies that interest rates may fail to drop low enough to revive and economy because bank earnings might not permit it in an acute Depression. Moreover, contemporary students of money and banking have not reconciled a fundamental problem of the current system of bank regulation: that the Federal Reserve system is charged with performing two often incompatible tasks - that of advancing the interests of specific industry while simultaneously overseeing the protection of other business and the public at a large". (1984, 982-983)
} 
$1974,133)$ The unsustainability of this situation was made explicit when the states of New York and Illinois suspended banking operations on the eve of Roosevelt's inauguration on Saturday March 4, 1933. In anticipation of the domino effect that this announcement would have on commercial banking nationwide, Roosevelt declared a national bank holiday on March 5 until March 9, which was subsequently extended through March 13. Faced with this virtual cessation of financial intermediation, dramatic banking reform became an urgent priority of the incoming Roosevelt administration.

\section{The Emerging Critique Of Diversified Financial Capitalist Firms In The Early 1930s}

In view of the virtual collapse of the commercial banking system, the Roosevelt administration was obliged to take immediate action to stabilize commercial banking, and to devise a regulatory framework intended to prevent the recurrence of such calamities in the future. In the midst of this debate concerning how best to address the devastation of commercial banking, the diversified financial capitalist firm came under intense scrutiny. Senator Carter Glass, a recognized authority in financial matters owing to his role in the creation of the Federal Reserve System in 1913, argued that the blending of commercial and investment banking within a single financial capital firm promoted speculative activity on the part of commercial banks, which in turn undermined the solvency of the commercial banking system. Glass had been arguing since the late 1920 s that the investment banking concerns had contaminated the banking system with "stock gamblers" who diverted commercial banking away from the "legitimate needs of business". (Perkins 1971, 499) In order to re-orient financial intermediation to the support of economic growth rather than speculation, Glass became a leading spokesperson calling 
for the abolition of diversified financial capitalist firms as a central component of the repair of American finance.

Glass and other critics of diversified financial capitalist firms often focused their critique of diversified financial capitalist firms on the conflicts of interest inherent in blending commercial and investment banking within a single firm. They charged that these conflicts of interest created incentives for commercial banks to make questionable loans to enhance the price of securities with which they (or their securities affiliates) were involved. This might take the form of advancing dubious loans to productive capitalist firms in an attempt to attract underwriting business. In the context of an euphoric stock market, productive capitalist firms whose public offerings of stock might not otherwise be attractive to prospective shareholders were encouraged to bring issues of their securities to market. In these situations, an infusion of debt capital is often helpful to enhance the appearance of productive capitalist firms prior to the execution of their public offering. Despite the doubtful merits of these initial loans, it was hoped that the lucrative revenues ensuing from securities underwriting (and other investment banking functions) would justify the additional risk taken in the commercial banking arm's loan portfolio.

These conflicts of interest between commercial and investment banking had further implications which also undermined commercial bank solvency. For example, it emerged that investment advice given to customers of these department store financial enterprises was highly suspect. Customers were sometimes persuaded to purchase highly 
questionable securities without adequate disclosure of the financial enterprise's relationship to the securities in question (as was the case in some of the debacles involving the National City Company). If the commercial banking arm of the financial enterprise advanced loans to facilitate the purchase of these securities, this contributed to the further deterioration of the quality of the commercial bank's loan portfolio. Furthermore, as stock market difficulties devastated the securities affiliates, commercial banks were often compelled to make questionable loans in an attempt to rescue their affiliates. Critics of the blending of commercial and investment banking claimed that these conflicts of interest culminated in the increasing riskiness of loan portfolios which increased the vulnerability of the commercial banking system to bank failures.

Condemnation of the blending of commercial and investment banking was intensified by the growing public awareness of the notorious activities that had occurred in diversified financial capitalist firms. One of the most sensational early banking failures, that of the Bank of the United States in December 1930, was attributed to the nefarious activities which were largely carried on through the bank's securities affiliates. (Perkins 1971, 496-497) The Gray-Pecora hearings (1932-1934) exposed the duplicitous conduct prevalent in even the largest and most prestigious financial enterprises thanks, in part, to the opportunities created by the combination of commercial and investment banking. For example. National City Bank (the world's second largest bank at the time and predecessor of today's Citigroup) and its securities affiliate, National City Company (the US's largest investment bank in the late 1920s) stood publicly accused of all sorts of dubious and possible illegal practices stemming from their diversified financial capitalist 
activities. ${ }^{25}$ At the conclusion of the hearings, one famous columnist of the period declared that " The only thing that some of our great financial institutions overlooked during the years of boom was the installation of a roulette-wheel for the convenience of depositors.". (in Carosso 1970, 330)

\section{Critiques Of Speculation And The New Deal Coalition For Financial Reform}

The Roosevelt administration came to power when it was politically feasible to act on this growing critique of financial capital to implement an ambitious program of financial reforms. Diversified financial capitalist firms, tainted by their association with the reviled money-trust, became emblematic of the most recent examples of the abuses of financiers. Under these circumstances, the New Deal could bring together a heterogeneous group to support New Deal financial reform, in part because of their common desire to reap political advantages by championing the growing public animosity towards financiers. An explicit commitment to the principles of Keynesianism was not required in order to support New Deal financial reforms, since a vilification of speculation would suffice to secure support for the early Banking Acts passed by the Roosevelt administration. Thus proponents of New Deal financial reforms included those

\footnotetext{
${ }^{25}$ For example, National City Company rescued the parent bank from the consequences of its disastrous Cuban Sugar loans by selling stock in the failing sugar company to investors who were not apprised of the dubious quality of these stocks. The proceeds of this public offering allowed National City Bank to avoid a large loan loss (Pecora 1939,122), but left stock-holders with next to nothing. Its questionable securities underwriting included bonds issued by borrowers that were earlier described by bank officials as "lax, negligent and entirely uninformed about the responsibilities of a long-term borrower"'(Carosso 1970, 330), National City was also suspected of manipulating copper prices to protect itself from losses on the large amount of Anaconda Copper Company stock it held. (Kotz 1978, 51)
} 
who espoused Keynesianism as this body of theory was evolving, and those with little commitment to (or perhaps even awareness of) Keynesian principles who nevertheless found their particular agendas provisionally coinciding with the Keynesian goals. ${ }^{26}$

Roosevelt offered himself as the public champion of this denunciation of the speculative excess of finance, claiming in his inaugural address that the "unscrupulous money-changers" have "fled from their high seats in the temple of our civilization" (in Kennedy 1973, 153), and now stood "'indicted in the court of public opinion, rejected by the hearts and minds of men'". (in Carosso 1970, 335) Roosevelt explicitly linked the crisis affecting commercial banking with the excessive speculation by bankers in the 1920s in his "fireside chat" of March 12, 1933.

We had a bad banking situation. Some of our bankers had shown themselves either incompetent or dishonest in their handling of the people's funds. They had used the money entrusted to them in speculations and unwise loans. This was, of course, not true in the vast majority of our banks, but it was true in enough of them to shock the people for a time into sense of insecurity and to put them into a frame of mind where they did not differentiate, but seemed to assume that the acts of a comparative few had tainted them all. It was the government's job to straighten out this situation and do it as quickly as possible. (in Krooss 1969, 2711)

Roosevelt's anti-finance rhetoric also garnered the support of some progressives who had longstanding animosity towards financial capital. For example, the Socialist Party was publicly demanding the outright nationalization of American banking,27, and was thus heartened when rumors abounded that the nationalization of banks was a

\footnotetext{
${ }^{26}$ Carter Glass, for example, dissented from Keynesian theory in many respects, to the extent that he turned down Roosevelt's offer of the position of Secretary of the Treasury, in part because of Glass's concerns about the inflationary implications of unbalanced government budgets. (See Burns 1974, 102-104)

${ }^{27}$ Norman Thomas, in the New York Times, 20 August, 1933. (quoted in Kennedy 1973, 168)
} 
possibility being considered by the Roosevelt administration. ${ }^{28}$ Despite the possibility that the nationalization threat may have been calculated to persuade the banking titans to comply with Roosevelt's reforms as the lesser of two evils, officials of considerable credibility were making dramatic statements that openly promoted the possibility of nationalization. Albert Agnew, General Counsel for the Federal Reserve Bank of San Francisco, warned ominously from the pages of a banking periodical, "'Either the bankers of this country will realize that they are guardians of the moneys committed to their charge, and will conduct themselves accordingly, or banking will cease to be a private enterprise and will become a purely government function."'(in Burns 1974, 73)

The anti-finance sentiment of the early 1930s created opportunities for the Roosevelt administration to intervene in the re-organization of the financial sector in ways that might have been considered far too invasive in the absence of public animosity towards finance. At the same time, this vilification of finance (and the subsequent redemption of finance thanks to the remedial efforts of New Deal financial reforms) served another political agenda. The American public was provided with the cathartic benefits of having a villain to revile. By explicitly or implicitly attributing the economic ills of the 1930s to the speculative proclivities of diversified financial capitalist firms, and of unrestrained financial capital more generally, productive capital was exculpated from responsibility for these economic hardships. Thus New Deal reform could exonerate the capitalist class process from any responsibility for the economic misery of the great

\footnotetext{
${ }^{28}$ According to Rexford Tugwell's biography, brain-trusters had briefly considered "[a] new banking system that would take out of private hands the creation of a nations' vital medium of exchange." (in Burns $1974,112)$
} 
depression by catalyzing public anger towards the suspicion of financial capital. The New Deal could claim to herald the dawn of a better capitalism, provided that finance was constrained to perform its rightful role. Capitalist exploitation per se was never the subject of debate, the New Deal sought only to secure the conditions for capitalist exploitation to proceed.

While it is not surprising that the Roosevelt administration failed to scrutinize the capitalist class process in its attempt to deal with the economic calamity of the great depression, it is another matter that leftists also failed to register the opposition to an exploitative economic system prominently among their demands. By focussing on questions of private ownership of financial capitalist firms, the concentration of financial power, or the possibilities of the centralized planning of credit allocation, leftists were able to occupy the left extremes of a spectrum of public debate concerning these issues. Despite winning some concessions to their demands in these debates, leftists were nevertheless engaged in a debate whose terms precluded the critique of exploitation per se. Demands for class transformation were not portrayed as a legitimate part of the public debate, either by the spokespeople of the New Deal or by the leftists who otherwise regarded themselves as critics of the prevailing economic system. 


\section{CHAPTER 5}

THE CONTRADICTORY IMPERATIVES OF NEW DEAL FINANCIAL REFORMS

\section{The Contradictory Imperatives of New Deal Financial Reform}

Faced with the imminent collapse of the commercial banking system, and the general economic devastation of the great depression, New Dealers were obliged to wrestle with contradictory imperatives in order to reorganize American finance to secure the conditions of existence for the Keynesian pursuit of economic growth and stability. On the one hand, the commercial banks urgently required supports to their profitability in order to alleviate the banking failures that threatened the conduct of domestic financial intermediation. On the other hand, the Keynesian accumulation agenda required that money capital should flow to productive capitalist firms in return for a low subsumed class payment. This accumulation agenda, summarized as the idea that financial capital should act as servant to productive capital, was potentially in conflict with the necessity of enhancing the profitability of commercial banks. Thus New Deal financial reformers were confronted with the urgent necessity of securing two of the conditions of existence for stable and vigorous accumulation, namely stable financial intermediation and cheap money capital, which were potentially in diametric opposition to one another.

This contradiction between the Keynesian accumulation agenda and the necessity of promoting commercial bank profitability is a specific instance of the master/servant contradiction discussed in chapter two. In chapter two, the master/servant contradiction implicit in the Keynesian agenda referred to the possibility that financial capital, when 
obliged to provide money capital in return for low subsumed class payments, might rebel from this subsumed class role by finding alternatives uses for the funds at their disposal. In the context of the current chapter, the master/servant contradiction is overdetermined by the devastating banking conditions during the great depression. The danger of the collapse of the commercial banking system meant that the restoration of commercial bank profitability was a condition of existence for the continuation of financial intermediation more generally. In this sense, this situation represents an extreme manifestation of the master/servant contradiction. Because of the possibility that commercial banks might cease to perform their subsumed class responsibilities entirely, financial capital (in this case commercial banks) could not act as servant to productive capital unless measures were taken to attend to the welfare of the servant. New Deal financial reforms had to contend with the possibility that the domination of the master by the servant would make the servant relationship unsustainable, and thereby make the master relationship unsustainable as well.

Under these circumstances, New Deal financial reforms were animated by the contradictory the necessity of both enhancing commercial bank profitability (to safeguard the stability of the commercial banking system) and constraining commercial bank profitability (as a consequence of securing the conditions of existences of cheap money capital). This chapter argues that the Glass-Steagall Act, in combination with certain other regulatory provisions in the Banking Acts of 1933 and 1935, attempted to manage these contradictory imperatives that animated the New Deal financial reform agenda. By re-organizing the class character of financial capitalist firms in the context of a new set of 
commercial banking regulations, financial reformers attempted to address both the imperative of commercial bank profitability and the imperative of the availability of cheap money capital to support accumulation.

This chapter provides a Marxian class analysis of the ways in which selected provisions of this New Deal financial legislation addressed this complex financial reform agenda. In doing so we highlight how these measures reshaped competition among financial capitalist firms. In some respects these reforms addressed competition among financial capitalists in the second moment of financial intermediation, thus these reforms were interventions that directly affected subsumed class struggle among financial capitalists. In other respects, these reforms reshaped competition among financial capitalists in the first moment of financial intermediation. In this case, these interventions were not directly addressing subsumed class struggle among financial capitalists, but were overdeterminants of the conditions of existence of subsumed class struggle among financial capitalists. The New Deal financial reforms constituted a complex mixture of regulatory provisions that addressed both moments of financial intermediation in the attempt to manage the contradictory imperatives involved in securing the conditions of existence for both commercial bank profitability and the availability of cheap money capital. 
The Banking Act of June 16, 1933 constituted the first major initiative of the Roosevelt administration to reform the conduct of financial capitalist activity in the United States. ${ }^{1}$ One of the Banking Act's most prominent provisions was what has come to be referred to as the Glass-Steagall Act. ${ }^{2}$ The Glass-Steagall Act is not an act per se, but certain subsections of the Banking Act of 1933. Section 20 of the Act required commercial banks belonging to the Federal Reserve System to divest themselves of their securities affiliates within one year. ${ }^{3}$ This provision, in combination with the other GlassSteagall sections ${ }^{4}$, effectively ended the combination of commercial and investment banking within a financial capitalist firm in the United States. ${ }^{5}$ Glass-Steagall forced the prompt dismantling of prominent diversified financial capitalist firms, such as JP

\footnotetext{
${ }^{1}$ The Banking Act of 1933 was preceded by the Emergency Banking Act of March 9, 1933 (which proclaimed the National Banking Holiday), however that act was motivated to contain the banking crisis rather than to institute structural reforms.

${ }^{2}$ The Glass-Steagall Act discussed below should not be confused by the earlier Glass-Steagall Act of February 1932, which instituted some amendments to the Federal Reserve Act concerning rediscounting practices at Federal Reserve banks.
}

${ }^{3}$ "' $\{$ n $\}$ o member bank shall be affiliated in any manner... with any corporation, association, business trust, or other similar organization engaged principally in the issue, flotation, underwriting, public sale, or distribution at wholesale or retail or through syndicate participation of stocks, bonds, debentures, notes or other securities." " (in Kross 1969, 2760)

${ }^{4}$ Section 16 prohibited commercial banks from purchasing equities and underwriting securities on their own behalf (with the exception of US Treasuries and general obligations of states and political subdivisions), section 21 prohibited investment banks from accepting deposits, and section 32 prohibited interlocking directorates between commercial banks and investment banks.

${ }^{5}$ Glass advocated for the separation of commercial and investment banking, while Steagall supported deposit insurance. The compromise between these agendas allowed both issues to be dealt within the Banking Act of 1933. However the appellation "Glass-Steagall Act" for the sections of the Act that separated commercial and investment banking is ironic in that the deposit insurance issues pressed by Steagall are actually dealt with elsewhere in the Act. 
Morgan's ${ }^{6}$, that were emblematic of the evils of finance in popular culture. Fortuitously, this attack on the epitome of financial power enabled the Roosevelt administration to claim the moral high-ground in the battle against the evils of financial speculation and the abuses of financial capital more generally. Thus Glass Steagal conferred credibility upon New Dealers anti-finance rhetoric, which proved politically convenient given that, as will be argued below, New Deal financial reforms were also simultaneously implementing measures to enhance the profitability of financial capital.

The preamble of the Banking Act of 1933 describes the Act as "[a]n act to provide for the safer and more effective use of the assets of banks, to regulate interbank control, to prevent the undue diversion of funds into speculative operations, and for other purposes". (in Kross 1969,2758) By removing investment banking activities from firms that engaged in commercial banking, the architects of this financial reform intended to shield commercial bankers from the speculative opportunities that arise from dealings in securities. In this way, the Act attempted to protect the deposit base of the economy from involvement in the speculative pursuit of short-term capital gains on securities markets. Provisions were also made to punish commercial banks that directed bank credit toward "'the speculative carrying of or trading in securities, real estate, or commodities, or for any other purpose inconsistent with the maintenance of sound credit conditions." (in

\footnotetext{
${ }^{6}$ J.P. Morgan's financial empire was carved into two separate companies: Morgan Stanley pursued investment banking while J.P. Morgan \& Company engaged in commercial banking.
} 
Friedman and Schwartz 1963, 443) ${ }^{7}$ O'Conner, the comptroller of the currency from 1933-1938, indicated that the intent of the Act was that banks were henceforth prevented from "acting as a medium or agent for non-banking corporations, firms or individuals in making loans to brokers on the security of stock, bonds and other investments."

(O'Conner 1938, 22)

From a class analytic point of view, the Glass-Steagall Act mitigated against domination of productive capital by financial capital in a manner reminiscent of Hilferding's finance capital. By prohibiting the blending of banking and non-banking financial capitalist activity within a single firm, Glass-Steagall limited the opportunity to manage subsumed class struggle among financial capitalists by creating large financial capitalist firms that could dominate the provision of money capital. Commercial banks had the advantage of having access to the deposit base, but they were prohibited from engaging in the provision of equity capital. Investment banks could engage in the provision of both debt and equity capital, but they were denied access to the deposit base. To the extent that Glass-Steagall's prohibition of diversified financial capitalist firms constrained the ability of financial capitalist firms to control access to both varieties of money capital, the Act was supportive of intensified subsumed class struggle among financial capitalist firms in the second moment of financial intermediation.

\footnotetext{
${ }^{7}$ Friedman and Schwartz point out that banks judged to be advancing credit for inappropriate purposes could be suspended from access to the credit facilities of the Federal Reserve, and the amount of loans secured by stock or bond collateral were to be subject to a quota imposed in each Federal Reserve district.
} 
In addition to prohibiting diversified financial capitalist firms, the Glass-Steagall Act (together with amendments to sections 20 and 21 of the Federal Reserve Act) also attempted to prevent the establishment of diversified capitalist firms that blend commercial banking with productive capitalist and merchant capitalist activities. By constraining the securities that a commercial bank was entitled to hold, commercial banks could not buy equities in an effort to control productive capitalist or merchant capitalist firms (Krainer 2000, 6-17). This limited the formation of diversified capitalist firms, but this restriction was evaded as commercial banks formed holding companies in order to control both bank and non-bank subsidiaries. In time this loophole was closed with the passage of the Bank Holding Company Act (BHCA) of 1956. The BHCA was explicitly justified as a measure "to maintain the traditional separation between banking and [commerce] in order to prevent abuses of allocation of credit." (in Hayes 1987, 49) It clearly prohibited bank holding companies from acquiring "direct or indirect ownership or control of any voting shares of any company which is not a bank". (Krainer 2000, 17) Once this loophole in the Glass-Steagall provisions was closed, commercial banks were prevented from forming holding companies in order to establish diversified capitalist firm. ${ }^{8}$

\footnotetext{
${ }^{8}$ Non-bank financial capitalist firms and productive capitalist firm could acquire up to $25 \%$ of voting shares in a bank's outstanding equity capital. However, any stake in excess of this threshold obliged the acquiring firm to become a bank holding company. (Krainer 2000,17)
} 


\section{Enhancing Commercial Bank Profitability Without Increasing The Costs Of Accessing Money Capital: A Return To The Two Moments Of Financial Intermediation}

Whatever the merits of the Glass-Steagall regulations concerning the class character of firms in promoting a situation in which financial capital would act as servant to productive capital, the New Deal's Keynesian aspirations of promoting economic growth and stability were unattainable so long as the commercial banking system was in spectacular disarray. Unless commercial banking became profitable, instability in the commercial banking system would continue to disrupt the process of financial intermediation and thereby jeopardize the recovery of aggregate demand. Yet in some respects the Glass-Steagall Act further exacerbated commercial bank profitability problems. Any strategy to enhance commercial bank profitability via the combination of commercial banking with non-banking revenue generating activities firm was now forbidden, thus commercial banks were forced to rely solely on revenues from commercial banking at a time when commercial banking was in crisis.

Thus while the Glass-Steagall Act promoted a re-organization of finance in pursuit of one of the conditions of existence of stable and vigorous accumulation (cheap money capital), it potentially detracted from a further condition of existence of stable and vigorous accumulation, namely the profitability of commercial banking. This presented the architects of New Deal financial reform with a dilemma. Any measures to enhance the profitability of the commercial banking system had to be carefully designed, for these measures would defeat the larger logic of the Keynesian agenda if commercial bank 
profitability was restored by making access to money capital more costly. Confronted by the contradictory imperatives of the Keynesian financial reform agenda, New Deal financial reforms sought to design regulatory interventions that would enhance bank profitability while attempting to avoid exerting upward pressure on the subsumed class payment required to secure money capital.

To discern how New Deal financial reformers attempted to perform this complicated feat, we must return to the distinction between the first and second moments of financial intermediation. We have argued thus far that the Keynesian economic agenda sought low subsumed class payments for access to money capital, thus potentially putting downward pressure on commercial bank profitability in the second moment of financial intermediation. However, commercial bank profitability is also affected by the first moment of financial intermediation. If, in the first moment of financial intermediation, commercial banks are able to access funds more cheaply, or if they have access to more funds, this enhances their potential profitability. ${ }^{9}$ By enhancing commercial bank profitability in the first moment of financial intermediation, commercial banks could be compensated for the detrimental pressure on commercial bank profitability that these same New Deal reforms imposed on the second moment of financial intermediation.

\footnotetext{
${ }^{9}$ If funds are secured more cheaply in the first moment of financial intermediation, this enhances commercial bank profitability by enhancing the "spread". The spread, in mainstream banking parlance, is the difference between the interest rates paid to lenders and the interest rates paid by lenders to secure funds. The New Deal financial regulation discussed below both increase the spread, and enhance the volume of funds intermediated by commercial banks. Both of these actions enhance commercial bank profitability.
} 
In this manner, New Deal financial reforms sought to manage the inherent contradictions of the Keynesian financial reform agenda. New Deal financial reforms acted to constrain the profitability of commercial banks (and financial capital in general) by intensifying subsumed class struggle among financial capitalists. Yet this potentially profit-constraining intervention in the second moment of financial intermediation was accompanied with measures that were intended to support the profitability of commercial banks in the first moment of financial intermediation. In this way, the profitability of commercial banks might be secured while moderating the deleterious effects of increased commercial bank profitability on the Keynesian agenda of promoting accumulation via the availability of cheap money capital. In attempting to both constrain and enhance the profitability of commercial banks, New Deal financial reforms sought to sustain a delicate balance. If commercial banks were not sufficiently profitable, the continuing crisis in financial intermediation would compromise the Keynesian agenda. Yet, as we shall discuss in chapter six, if commercial banks were to become too profitable, the Keynesian agenda would also be comprised.

\section{New Deal Supports To Commercial Bank Profitability In The First Moment Of Financial Intermediation}

In order to support commercial bank profitability in the first moment of financial intermediation, the Glass-Steagall Act was implemented alongside other New Deal financial reforms. The creation of deposit insurance and interest rate controls were incorporated into the Banking Act of 1933, and these measures were later supplemented by the termination of free banking in the Banking Act of 1935. Taken as a group, these 
measures enhanced commercial bank profitability by assisting commercial banks in attracting funds in the first moment of financial intermediation, and by creating conditions that enabled commercial banks to reduce the costs of attracting these funds.

To end the paralyzing waves of bank failures in the commercial banking system, Henry Steagall and others incorporated a national system of deposit insurance in the Banking Act of 1933. A new federal agency, the Federal Deposit Insurance Corporation (FDIC), was established to insure deposits (initially up to a maximum of $\$ 5,000$ ) in the event of bank failure. While the initial funds for the FDIC were provided by the United States Treasury and the twelve Federal Reserve Banks, commercial banks would henceforth pay premiums to the FDIC in return for deposit insurance. This constituted a new $\mathrm{Y}$ expense for commercial banks, and thus deposit insurance was initially (and briefly) opposed by many commercial banks, particularly the large urban commercial banks, who complained that the burden of premiums was a further detriment to commercial bank profitability. ${ }^{10}$ However commercial bankers were quickly convinced of the merits of deposit insurance as public confidence in banks increased. After the prolonged calamity of bank failures in the early 1930s, bank failures moderated dramatically after the introduction of deposit insurance. The relatively modest rates of bank failures since the creation of deposit insurance are a stark contrast to the high rates of bank failures that had characterized American banking prior to the FDIC.

\footnotetext{
${ }^{10}$ The initial opposition of large commercial banks to deposit insurance may be a reflection of the fact that bank failures were particularly acute in rural areas, while large urban banks perceived themselves as better able to weather the banking crisis or saw themselves as "too big to fail" and therefore more likely to be given support by the Federal Reserve. (O'Conner 1938, 24)
} 
Figure 17: Numbers of FDIC-Member Commercial Bank Failures

(measured at year end)

Source: Historical Statistics on Banking, $\mathrm{CB} 02$.

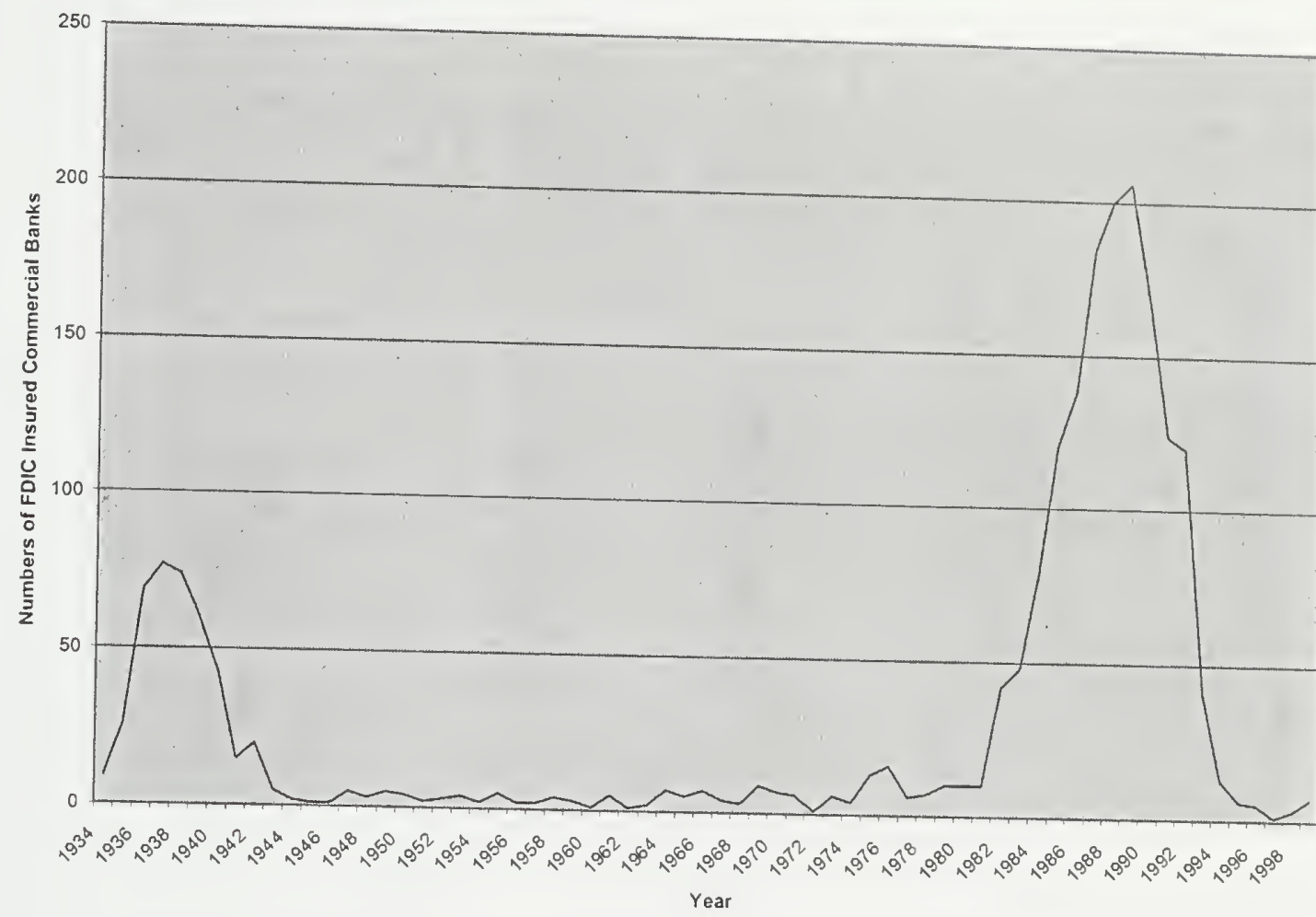

Deposit insurance gave commercial banks a competitive advantage over other financial capitalist firms, in that explicit government protection was only enjoyed by savings held in the form of deposits. In the context of the great depression, in which a traumatized public placed considerable value on the security of their savings, deposit insurance conferred a monopsonistic advantage on commercial banks vis à vis other financial capitalist firms. This helped to reverse the precipitous decline in deposits in commercial banks that had destabilized the commercial banking system prior to the passage of the Banking Act of 1933. Deposits recovered from their low point of \$27 billion in 1933 to surpass $\$ 49$ billion by 1939 (see Figure 16, chapter 4). As deposits 
flowed back into the commercial banking system, this enhanced the profitability of commercial banks, provided of course that those deposits would be employed to earn income either through advancing loans or purchasing government securities.

Alongside deposit insurance, the Banking Act of 1933 placed interest rate controls on deposits to enhance commercial bank profitability in the first moment of financial intermediation. Regulation Q set maximum interest rates that could be paid on savings deposits $^{11}$, and the previously common practice of paying interest on checkable deposits was prohibited. From a class analytic perspective, interest rate controls decreased the Y expenses required to attract a given amount of deposits, thereby enhancing commercial bank profitability. The coup de maitre of this subsidy to commercial bank profitability was its justification as a deterrent to speculation. Many New Dealers were convinced that excessive competition in the first moment of financial intermediation had been responsible for bidding up the costs of funds for commercial banks in the first moment of financial intermediation. In public debate at the time of the Banking Act's passage, it was widely claimed the high costs of securing loanable funds had induced banks to make highly risky loans connected with securities markets in order to earn sufficient returns to cover their costs of funds (see Friedman and Schwartz 1963, 443). By controlling the cost of securing loanable funds, Senator Glass argued that interest rate controls on deposits

\footnotetext{
${ }^{11}$ Strictly speaking, Regulation Q was implemented by the Federal Reserve. The Banking Act of 1933 empowered the Federal Reserve to implement Regulation Q by giving it the authority to impose interest rate ceilings on time and savings deposits at member banks. In the 1935 Banking Act, authority to extend Regulation Q ceilings, and the prohibition on the payment of interest on demand deposits, was extended to all federally insured banks. (Mason 1997, 26-7)
} 
would " "put a stop to the competition between banks in payment of interest, which frequently induce[s] banks to pay excessive interest on time deposits and has many times over again brought banks into serious trouble." (in Vietor 1987. 20)

In the context of the great depression, deposit insurance and interest rate controls worked together to support commercial bank profitability. The interest income forgone by depositors under the regime of New Deal interest rate controls represents an implicit subsidy to commercial banks. Yet despite the ability of non-bank financial capitalists to pay unregulated rates of return, holding savings in deposit form was attractive because of the security conferred by deposit insurance. Given the public's distrust of corporate equities and bonds as vehicles to store savings during the great depression, the government backing of deposit insurance made possible a situation in which depositors willingly provided this implicit subsidy to enhance the profitability of commercial banks. This subsidy to commercial banks was most dramatic in the case of demand deposits. Commercial banks were virtually the only type of financial capitalist firm that could offer checking privileges, while savings held at other financial capitalist firms were much less accessible for the purpose of executing transactions. Thus depositors -such as productive capitalist firms- who required checking privileges were compelled to hold their savings in interest-free in checking accounts. ${ }^{12}$ Ironically, a productive capitalist firm in this situation would be subsidizing bank profitability in the first moment of financial

\footnotetext{
${ }^{12}$ Household depositors did have access to some other institutional savings venues (savings and loans associations, credit unions etc.) that offered some checking privileges. However capitalist enterprises were largely confined to using the services of commercial banks if they wanted checking privileges, which at the time were indispensable for paying employees and managing accounts payable and receivable.
} 
intermediation as a condition of existence for the New Deal agenda to compel financial capital to act as servant to productive capital in the second moment of financial intermediation.

The synergistic effects of both deposit insurance and interest rate controls supported commercial bank profitability both because of the greater availability of funds in the first moment of financial intermediation, and because of diminished cost of securing each dollar of deposits. Commercial banks paid as much as 2 cents of interest for every dollar in deposits prior to 1929, while by the late 1930s banks paid under one half of one cent interest per dollar of deposits (see Figure 18). This dramatic downward pressure in the $Y$ expenses associated with attracting deposits provided substantial support to commercial bank profitability. Remarkably, while deposits grew $81 \%$ by the end of the 1930s from their low point in 1933, the total interest paid by commercial banks on deposits declined dramatically (see Figure 19). 
Figure 18: Interest Paid On Deposits Per Dollar Of Deposits Attracted At Federal Reserve Member Banks

(deposits measured at year-end call date)

Source: Banking and Monetary Statistics, 72-75, 262-265.

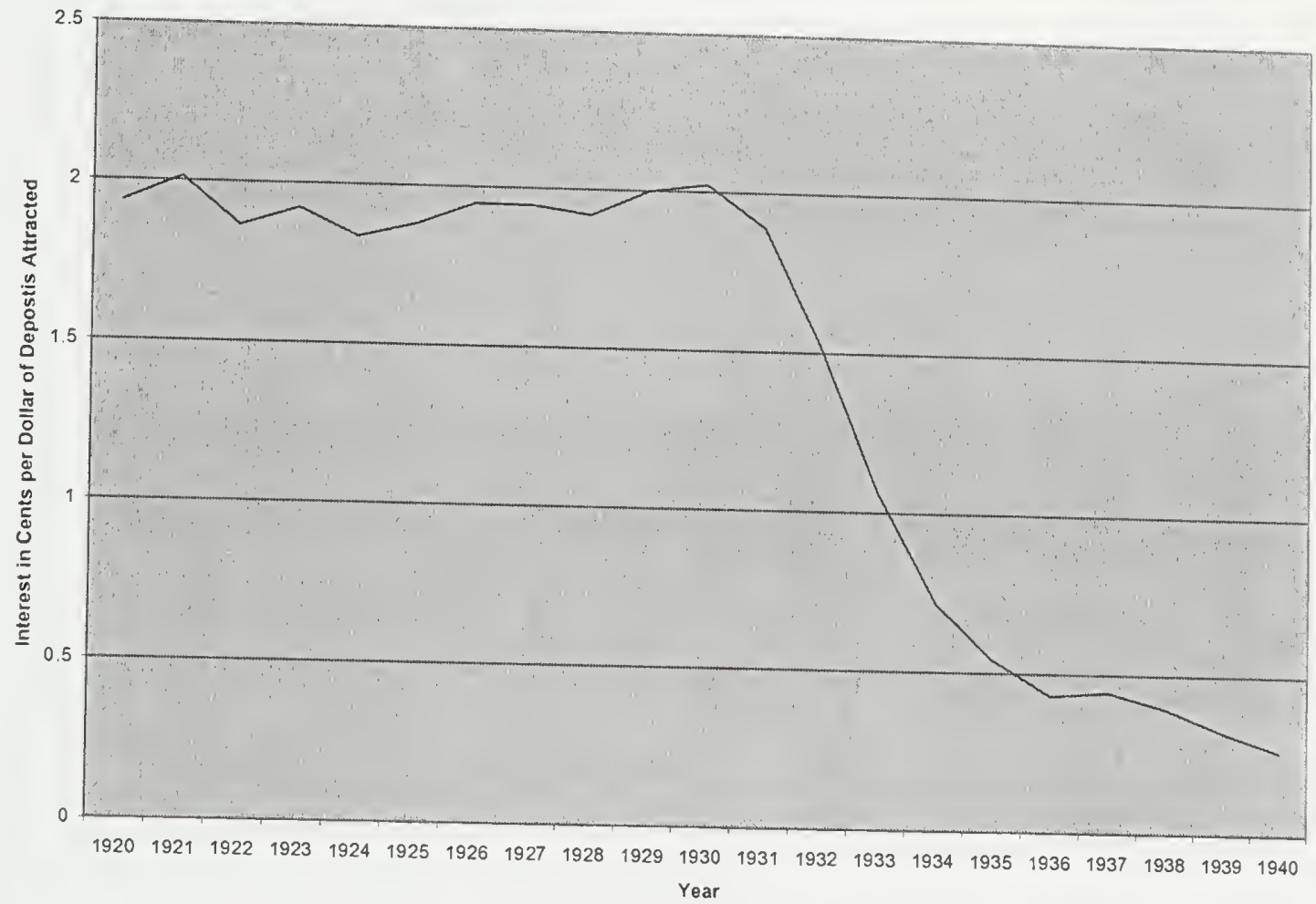


Figure 19: Total Interest Paid on Deposits At Federal Reserve Member Banks (Deposits measured at year-end call date)

Source: Banking and Monetary Statistics, 72-75, 262-265.

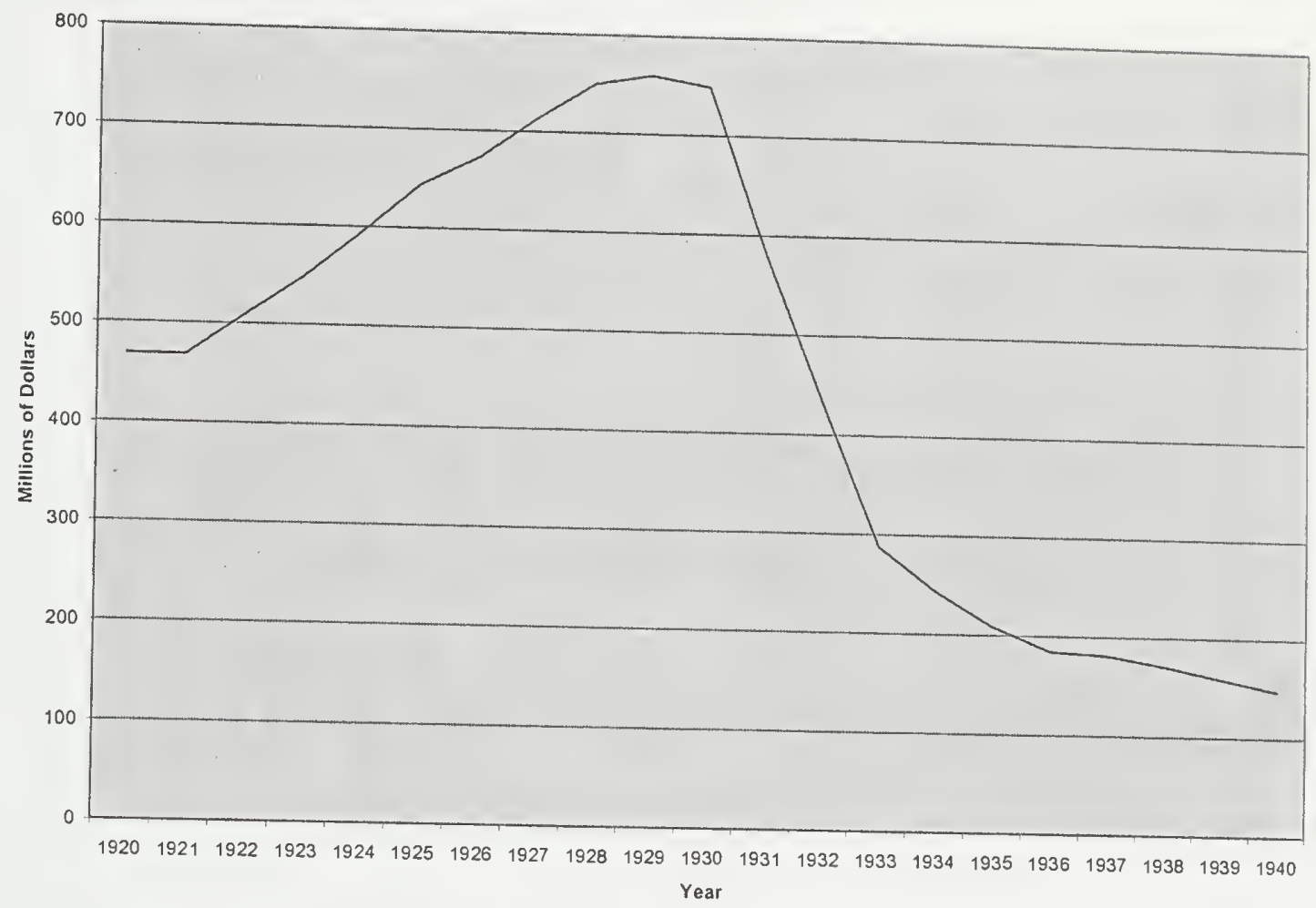

With the advent of government sponsored deposit insurance, the moral hazard dilemma implicit in the state/commercial bank relationship was intensified. Bank failures now represented an enormous liability for the state, in that the obligation to make good on all insurable depositor losses may divarf premiums paid by commercial banks. Thus deposit insurance intensified the degree to which the state was concerned to promote the welfare of commercial banks, since the state faced the additional consideration of its potential liability in the event of widespread crisis in commercial banking. This link between the health of the deposit insurance fund and the profitability of commercial banks as a condition of existence of commercial bank stability and was acutely 
understood by FDIC representatives. As a recent FDIC review of the history of deposit insurance has summarized:

For its part, the FDIC was faced with a dilemma [during 1934]. Although the bank failure rate had dropped precipitously, and the capital rehabilitation program of the RFC and the FDIC had been modestly successful, the banking system was not strong and the prospects for bank earnings were not bright. Additionally, the fears and uncertainties regarding bank failures had not been dispelled by 1934 and indeed would not recede for more than two decades. The FDIC was thus faced with the problems of protecting the earnings of insured banks until capital and reserve positions could be rebuilt while, conserving what was by historical standards a modest deposit insurance fund. (FDIC 1998, 36)

To further support commercial bank profitability in the first moment of financial intermediation, New Deal financial reformers turned their attention to the problem of overbanking. Brain-trust member Adolph Berle, in his address to the New York Bankers association shortly after the passage of the Banking Act of 1933, explained the dilemmas posed by excessive commercial bank competition in the first moment of financial intermediation as follows:

Is there any sense in having the First Trust Company on one side of the street competing with the Second State Bank on the other to draw deposits from one unit to make its own unit larger?

There can be only one result. The net pool is not enlarged. That can be done only by credit or by the slow growth of population and the growth of production, in the particular community which you serve. Competition between the two banks can only end in weakening one at the expense of the other, to the advantage of neither. $(1933,8)$

To address the implications of competition to attract deposits, the FDIC became an important source of pressure to eliminate "unfettered" competition in commercial banking, and instead sought to create conditions of "rightful competition" in commercial banking (FDIC 1998, 33). This culminated in the elimination of free banking in the Banking Act of 1935. The Act gave chartering bodies a degree of discretion over entry 
into commercial banking, and one of the criteria that had to be met before a new commercial bank could be chartered included regulatory consideration of the "future earnings prospects" of the bank. ${ }^{13}$ This legal obligation imposed on banking regulators by the Act stood as an explicit official acknowledgement that the profitability of commercial banks was a consideration that should guide banking regulators. Pleased with the restraints to competition implied by the Act, the FDIC hailed the 1935 Act as an aid to "prevent the recurrence of the evil which is to be greatly feared ... the return of the overbanked condition of the twenties." (in Klebaner 1990, 162)

As a result of both the elimination of free banking, and the general crisis afflicting commercial banking in the 1930 s, the numbers of commercial banks in operation in the United States was dramatically reduced. At its highpoint in 1921, there had been 29,417 state and nationally chartered commercial banks in the United States, and by 1929 this figure stood at 24,258. (Members of the Staff of the Board of Governors of the Federal Reserve System 1941, 419). The bank failures of the 1930s, together with the new restrictiveness in permitting entry into commercial banking following the passage of the Banking Act of 1935, reduced the number of FDIC- insured commercial banks in operation to 13,538 in 1939 . Klebaner claims that by 1940 there was an average population per commercial bank rose to 7,400 , nearly double that of 1920 . (Klebaner, 1974, 158) The number of commercial banks in operation have never grown substantially beyond this level, (although a small increase in numbers of commercial banks occurred

\footnotetext{
${ }^{13}$ Officials were directed in the Act to consider "' the financial history and condition of the bank, the adequacy of its capital structure, it future earnings prospects, the general character of its management, the convenience and needs of the community to be served, and whether or not its corporate powers are consistent with the purposes of this section"'. (in Hammond 1941,60-61)
} 
briefly in the late 1970s and early 1980s). Klebaner credits lack of growth in numbers of commercial banks to regulatory restrictiveness in granting entry into commercial banking. In support of this claim he cites an unnamed report of the Controller of the Currency claiming that 1936 marked a quarter century swing to "the extreme of unduly restricted approval" of new bank charters (Klebaner 1974, 158).

Figure 20 Numbers of FDIC-Insured Commercial Banks, 1934-2001 Source: FDIC, Historical Statistics on Banking, Table CB02.

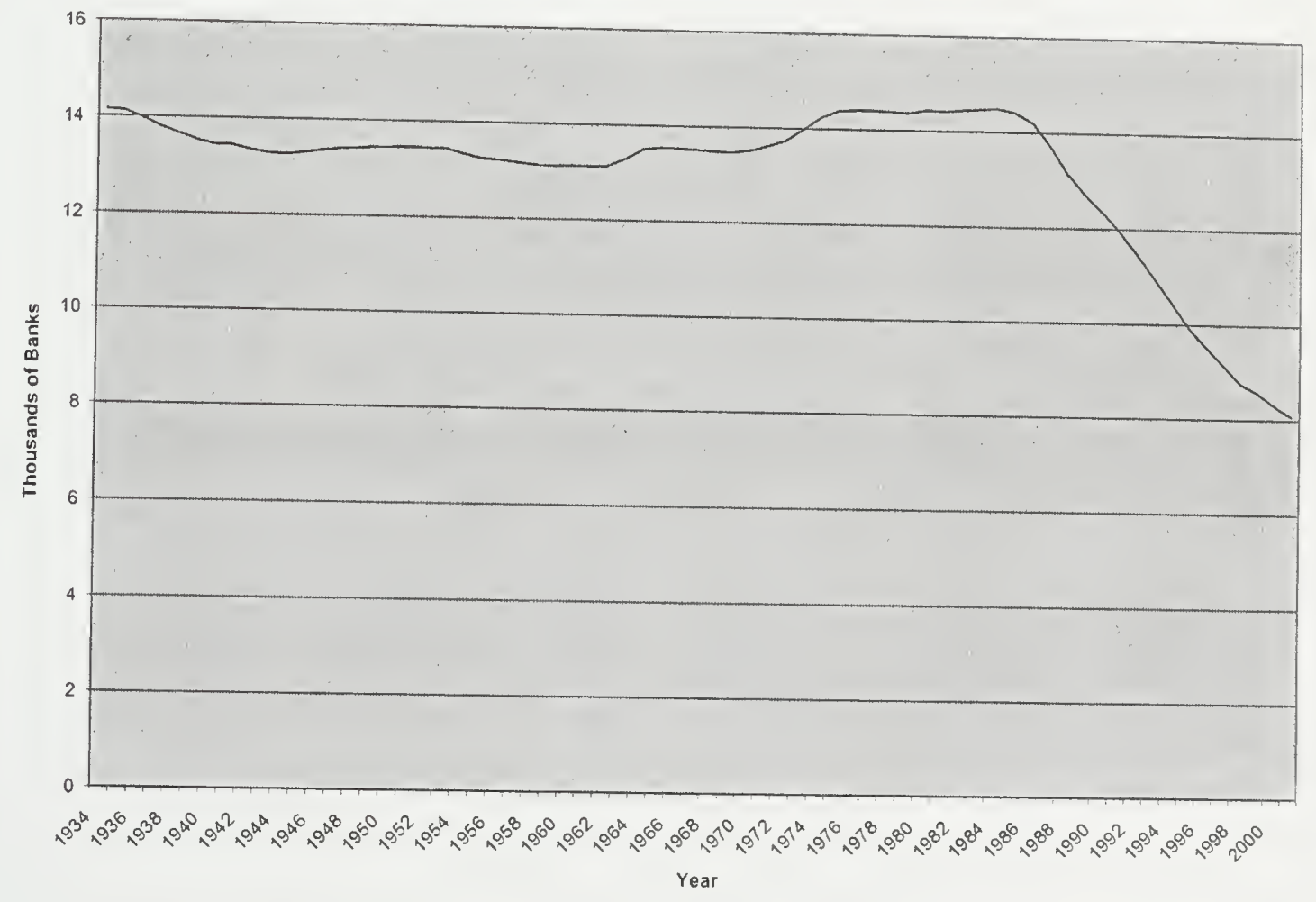




\section{The Multiple and Divergent Competitive Effects \\ Of New Deal Financial Reform}

The Banking Acts of 1933 and 1935 had multiple and often divergent effects on both commercial bank profitability and competition. On the one hand, the Glass-Steagall undermined commercial bank profitability, since it enhanced competition among financial capitalist firms in the sense that it prevented commercial banks from dominating access to both debt and equity capital via the creation of diversified financial capitalist firms. This enhanced competition is understood in class analytic terms as an intensification of subsumed class struggle among financial capitalist firms. Yet on the other hand, New Deal interest rate controls, FDIC protection and the erection of barriers to entry around commercial banking, enhanced the profitability of commercial banks by deterring competition in the first moment of financial intermediation. These deterrents to competition did not necessarily imply a moderating influence on the subsumed class struggle among financial capitalist firms generally. Despite the privileges granted to commercial banks, they still had to contend with other financial capitalist firms (insurance companies, pension funds, investment banks etc.) that provided debt and/or equity capital to productive capitalist firms. So long as subsumed class struggle was vigorous in the second moment of financial intermediation, Keynesian financial reformers were able to enhance the profitability of commercial banks in the first moment of financial intermediation without necessarily subverting their agenda for low subsumed class payments for access to money capital. ${ }^{14}$

\footnotetext{
${ }^{14}$ Of course, this is not to say that restrictions on competition in the first moment of financial intermediation had no effect on subsumed class struggle in the second moment of financial intermediation. Subsumed class struggle in credit and equity markets are shaped by a host of factors including competitive conditions in the first moment of financial intermediation, as well as the banking regulations of the various
} 
This approach to managing competition among financial capitalist firms became the hallmark of the organization of finance in the Keynesian welfare state. In this so-called "cartelization of finance", financial capitalist firms were classified according to the particular method through which they gathered funds in the first moment of financial intermediation. Financial capitalist firms of one category were largely prohibited from entering activities classified in another regulatory category. Commercial banks, investment banks, insurance companies, pension funds and so on were all separately regulated and confined to gathering of savings in the manner characteristic of their particular regulatory classification. This financial regulatory framework characteristic of Keynesian welfare state capitalism inhibited financial enterprises of different functional classifications from competing with each other over access to savings. This restricted competition across regulatory categories, but did not preclude competition within regulatory categories. Moreover, all of these types of financial capitalist firms continued to compete with each other in the second moment of financial intermediation, thus preserving the benefits of subsumed class struggle among financial capitalist firms in terms of its downward pressure on the subsumed class payment required to secure money capital.

state jurisdictions, the existence, diversity and regulation of non-bank financial capitalist firms in each jurisdiction, as well as the numerous other factors. Thus it is possible that in some areas and at some times restrictions competitive activities related to accessing savings may have translated into upward pressure on the subsumed class payment required to secure money capital. The point here is that, with sufficient subsumed class struggle in the second moment of financial intermediation, the regulatory moderation of competition in the first moment of financial intermediation need not have subverted the Keynesian agenda for low subsumed class payment required to access money capital. 
This interpretation of the New Deal financial reform as embodying both pro- and anti-competitive impulses is at odds with much mainstream financial literature from the 1970s and beyond. Following the publication of Friedman and Schwartz's influential A Monetary History of the United States in 1963, mainstream economics began to embrace the argument that banking failures during the depression were attributable to faulty government intervention rather than reproachable conduct on the part of financial capitalists. Since this literature largely absolved financial capitalists from a significant role in provoking the financial crises in the 1930s, it regarded New Deal financial regulation as an unnecessary and distortive impediment to the efficiency of financial markets. From this perspective, New Deal financial reforms were equated with the restraint of competition among financial intermediaries by authors such as Angermueller (1987) and Bentson (1990). As this anti-Keynesian critique gained momentum during the 1970 s and 1980s, it formed the intellectual backdrop for the advocacy of financial deregulation in the 1970 and 1980 s.

Nor would this class analytic perspective endorse a depiction of the GlassSteagall Act as a uniformly pro-competitive intervention. This interpretation has some currency among critics of large financial conglomerates, who often extol the separation of commercial and investment banking as a prerequisite to the establishment of genuinely competitive conditions among financial capitalists. This perspective may again grow in popularity in light of the frenzy of mergers and acquisitions among financial capitalist since the repeal of the Glass-Steagall Act in 1999. This ushered in a phase of even greater concentration among financial capitalist firms coinciding with the final phases of a stock 
market boom and subsequent bust. Critics of the speculative excesses and dubious business practices of these diversified financial capitalist firms again look to the prohibition of diversified financial capitalist firms as means of restoring the wholesome competition among financial capitalist firms that is conducive to economic growth.

Thus a class analytic perspective views New Deal financial reforms as having multiple, divergent and ultimately unanticipated effects on competition among financial capitalist firms. This dissertation seeks to avoid totalizing New Deal financial reform as either pro or anti-competitive, but rather sees this regulatory structure as necessarily both pro and anti-competitive. The illustration of the contradictory unity of these tensions relies on the distinction between the two moments of financial intermediation. The procompetitive dimension of these reforms, namely the intensification of subsumed class struggle among providers of debt and equity capital, was necessarily combined with anticompetitive measures as New Deal financial reformers attempted to grapple with urgent necessity of restoring and maintaining financial capitalist profitability. Neither pole of this dialectic can be forsaken. Both the affirmation and negation of competition form the unity in contradiction which constitutes New Deal financial reforms.

\section{New Deal Financial Reforms And The Advent Of Pax Financus}

New Deal financial reforms did not prove to be a panacea either for commercial banking profitability or for recovery from the great depression. Commercial bank failures were abated, deposits recovered and commercial banking interest expenses declined, however these developments were not sufficient to create propitious conditions for 
commercial bank profitability. While commercial bank profitability recovered dramatically in the early years of the New Deal financial reforms, the later 1930s were characterized disappointing commercial bank profits (see Figure 14, chapter 4).

Commercial bank profitability during the 1930 s was overdetermined by the difficult economic climate (as well as such factors as the effects of monetary policy), and in turn the commercial bank responses to their difficult profitability situation in turn overdetermined economic growth. Despite the increased stability in the commercial banking system following the passage of New Deal financial reforms, commercial banks were slow to resume their subsumed class role as providers of money capital to the capitalist fundamental class process. By December 30 of 1939, total loans of banks that were members of the Federal Reserve System stood at \$13,962 million, well off their height of \$26,165 million on October 4 of 1929.(Board of Governors of the Federal Reserve System 1943, 72-74) ${ }^{15}$ Moreover, commercial banks continued to hold excess reserves, which many critics viewed as an indication of the inefficacy of commercial banks in acting in their subsumed class role to promote accumulation, as well as an indication that they were an unreliable channel for the transmission of monetary policy.

In part because commercial banks were hesitant to resume their subsumed class role in lending to the capitalist fundamental class process, the government directed the Reconstruction Finance Corporation (RFC) to step into the breach. RFC had been created in 1932 during the Hoover administration in response to the crisis in commercial banking. The RFC had authority to borrow from the Treasury, and pursued a mandate "to extend

\footnotetext{
${ }^{15}$ If we remove loans made on securities from this total, the total non-securities related lending was $\$ 16,171$ On October 4, 1929 while by December 30, 1939 it was $\$ 11,980$.
} 
aid to agriculture, industry and commerce through the medium of direct loans to banks, trust companies and other financial institutions." (U.S. House of Representatives 1969, 22118) RFC authorized about $\$ 3.9$ billion in loans to banks and trust companies over its lifespan, and three fourths of this assistance was disbursed in the first 2.5 years of its existence. The role of the RFC was expanded when the Emergency Banking Act of 1933 authorized the RFC to invest directly in the preferred stock of commercial banks, thus staving off insolvency for many banks teetering on the precipice of failure. Thus the RFC constitutes another aid to commercial bank profitability, but it has not been incorporated into the above discussion of New Deal reforms because it was intended as emergence assistance rather than a component of the long-term regulatory infrastructure. Despite the funds made available to commercial banks via RFC, this was did not produce large infusions of money capital to promote accumulation, and by 1935 the RFC began to change its role. After 1935, RFC loans to financial institution diminished and they began to advance loans directly to "business enterprise and public agencies"(ibid..22120)" after 1938 the RFC was empowered to purchase securities and obligations from any business enterprise. In this manner, the RFC provided $\$ 5.1$ billion in loans to business enterprises, with an additional billion in loans to railroads. (ibid., 22120) However, once the post-war economic recovery began, the RFC was increasingly viewed as a competitor to private financial capitalist firms. Under aggressive lobbying by the

\footnotetext{
${ }^{16} \mathrm{RFC}$ was empowered to make longer term loans then were typical of commercial banks at the time, and this practices was later adopted by commercial banks. Term loans (with a maturity of more than one year) were negligible in 1933, but reached 2.2 billion by the end of 1940 . (Klebaner 1974, 147) Thus RFC is credited with lengthening the term of business loans in commercial banking, which increased the ability of productive capitalist firms to use bank loans to fund accumulation.
} 
commercial banking sector, legislators embraced the principal that "the RFC must not compete with private sources of credit"(ibid., 22119), and the RFC was liquidated in $1953 .^{17}$

From an overdeterminist point of view, it is not perplexing that the New Deal financial reforms did not in themselves remedy the great depression. The great depression was the product of a variety of interacting factors in addition to the crisis in commercial banking, such as the generally depressed demand conditions, international instability in both trade and financial conditions, dilemmas in the conduct of monetary policy and so on. Thus interventions to address the situation confronting commercial banking did not automatically overcome these multiple overdeterminants of persistent economic depression. However successful the New Deal restructuring of financial capitalist activity might be, if the economic situation is such that the demand for loans is not forthcoming, then accumulation will not proceed. The purpose of this dissertation is not to adjudicate whether the New Deal financial reforms "solved" the great depression; on the contrary such an inquiry would run counter the overdeterminist theory of causality. We look only to the ways in which the New Deal financial reforms were consistent with the Keynesian vision for economic growth. Thus our attention primarily turns to the post-war period to investigate the New Deal financial reforms during the heyday of Keynesian welfare state capitalism.

\footnotetext{
${ }^{17}$ Although the Small Business Administration, the Federal National Mortgage Association (Fannie Mae) and the Government National Mortgage Association (Ginnie Mae) were created to continue some of its activities.
} 
Following the war and the adjustment to a peace-time economy under radically

transformed international conditions, the US economy enjoyed a prolonged period of economic growth and stability under the auspices of the Keynesian welfare state. This period from the early 1950 s to approximately the mid-1970s is often referred to as the "golden age" of Keynesian welfare state capitalism. The New Deal financial regulatory framework is often regarded as an important support of this Keynesian golden age. Bank failures became uncommon, and credit was forthcoming from the commercial banking system at relatively low real interest rates. ${ }^{18}$ At the same time, commercial bank profitability, measured by Return on Assets, exhibited an upward trend through the early years of Keynesian welfare state capitalism (see Figure $21^{19}$ ). Thus despite the constraints imposed by New Deal financial reform, financial capital acquiesced to the regulatory framework created during the New Deal.

Although the reform legislation of the 1930s had divided up the financing terrain in what some thought was an arbitrary manner, the major financial intermediaries largely acceded to the legislation; it appeared to offer both an umbrella of protection against the well-remembered wrath of the public after the profligate 1920 s and an effective barrier to unwelcome competition. With each group's designated business territory in the financing landscape growing comfortably, there

\footnotetext{
${ }^{18}$ The association of the golden age of Keynesian welfare state capitalism and a regime of low real interest should not be taken as a claim that the New Deal financial reforms cause low real interest rates. As Crotty (2000) points out, a variety of international and domestic conditions converged to produce low real interest rates prior to the mid 1970 s.
}

${ }^{19}$ While the argument below proceeds in reference to the return on assets of FDIC-member commercial banks portrayed in Figure 21, it should be noted that a the return on equity behaves somewhat differently during the 1965-1980 than does return on assets. While the return on assets largely stagnated during this period, the return on equity climbed from $10.1 \%$ in 1965 to $13 \%$ by 1980 , and then declined roughly in step with return on assets thereafter. Thus those who regard the return on equity as a more important indication of profitability that return on assets may argue that the pressure on commercial banks was less acute in this time period. Since both ratios have the same numerator, the difference in the performance of these ratios is the result of difference in the valuation of assets and equity in this time period. Rather than entering into a discussion of the vagaries of the valuation of these various denominators, the argument is presented from the perspective of return on assets. However, the caveat is made that the return on equity, as well as other indicators of profitability, may at times provide conflicting indications of commercial bank profitability. 
was little incentive to encroach on the territory of the other financial intermediaries and thereby disturb the unspoken "pax financus" that appeared to be serving everybody reasonably well. (Hayes 1987,3 )

Figure 21: Return On Assets 1933-1999, FDIC-Member Commercial Banks Sources: $\underline{\mathrm{HSOB}}, \mathrm{CB} 04$ and CB09.

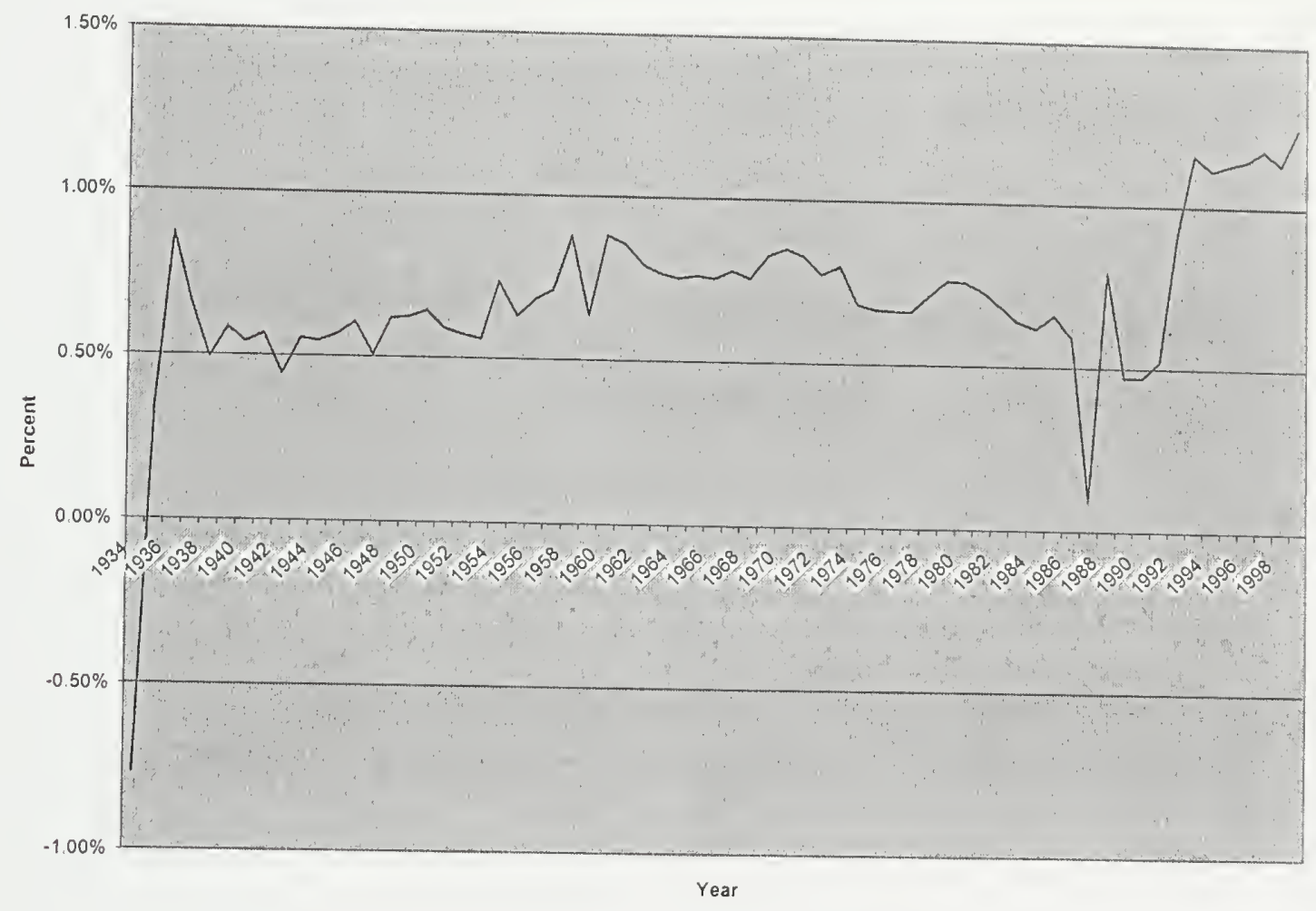

For close to three decades following the war, this "pax financus" persisted, and the financial regulatory framework created during the New Deal survived with little modification. However, as we shall discuss in the following chapter, the ability of the New Deal financial reform in terms of managing the potentially divergent imperatives of supporting both the conditions of existence for accumulation and commercial bank profitability did not persist indefinitely. The tensions inherent in managing the contradictory imperatives of New Deal financial reform ultimately contributed to 
unleashing forces that undermined the New Deal organization of financial capitalist activity. These strains were apparent in the renewed pressure on commercial bank profitability in the 1970s and 1980s. Thus while congratulating New Deal financial reformers on the ingenuity with which they balanced these conflicting imperatives, the remainder of the dissertation argues that the inherent contradictions animating this balancing act ultimately subverted the New Deal financial reforms. 


\section{CHAPTER 6}

\section{RISE OF BELLUM FINANCUS \\ AND THE CRISIS OF NEW DEAL FINANCIAL REFORM}

\section{From Pax Financus To Bellum Financus: The Contradictions Of New Deal Financial Reform And The Transformation Of US Financial Capital}

After a long "golden age" of economic growth and stability, Keynesian welfare state capitalism faced intensifying crises during the 1970s and 1980s. As these crises ramified, the Keynesian welfare state was largely abandoned as the preferred avenue through which to promote the continued wellbeing of the capitalist fundamental class process. While Keynesian welfare state capitalism was unraveling, the New Deal financial reforms that had helped to secure the conditions of existence of Keynesian welfare state capitalism were also under attack. Despite the lauded success of the New Deal financial regulatory framework in sustaining the pax financus that characterized the early golden age of the Keynesian welfare state, during the 1970s and 1980s this framework was manifesting ominous signs of strain. Ultimately the relative stability of pax financus gave way to a bellum financus, in which financial capitalist firms of various types engaged in vigorous competitive struggles that ultimately undermined the viability of the New Deal financial reforms.

This disintegration of the Keynesian financial regulatory framework during the dénouement of Keynesian welfare state capitalism is analyzed in this chapter as an overdetermined consequence of the contradictions that animated New Deal financial reform. Thus far the dissertation has made the case that New Deal financial regulations 
were obliged to balance two potentially divergent imperatives, namely the promotion of both low subsumed class payments for access to money capital and commercial bank profitability. Chapter five argued that New Deal financial reform attempted to deal with these two contradictory imperatives by instituting the so-called "compartmentalization" of finance. This compartmentalization of finance in some respects promoted and in some respects impeded competitive struggles among financial capitalist firms. Chapter six presents the case that the contradictions inherent in financial compartmentalization ultimately undermined this delicate balance between the pro and anti-competitive impulses of New Deal financial reform.

As is the case when the positive moment of the dialectic provokes its negation, the compartmentalization of finance was undermined by its own success. Amidst the relative tranquility of pax financus, incentives began to emerge to subvert the compartmentalization of finance. These opportunities unleashed new competitive struggles among financial capitalist firms that produced severe and unsustainable strain on the New Deal financial regulatory framework. As pax financus degenerated into bellum financus, many prominent aspects of the New Deal financial regulatory framework became a casualty of this intensified struggle among financial capitalist firms. As has been the case throughout the dissertation, the intensifying struggles among financial capitalist firms and the ensuing demise of the New Deal financial regulatory framework will be viewed from the vantage point of commercial banks. In particular, we 
will focus on the changing competitive struggles between commercial banks and their non-bank financial capitalist competitors, and the implications of these struggles on commercial bank profitability.

\section{The Inherent Contradictions Of New Deal Financial Reforms And The Provocation Of Bellum Financus}

The analysis of the ways in which the New Deal compartmentalization of finance provoked its own negation relies, in part, on the recognition that the compartmentalization of financial capital necessarily bestows an uneven assortment of advantages and disadvantages on the various types of financial capitalist firms. If financial capitalist firms in one compartment discern competitive advantages enjoyed by financial capitalist firms of a different regulatory category, the incentive exists for the relatively underprivileged financial capitalist firms to undermine those regulatory advantages. By the same token, any regulatory requirements that burdened a given category of financial capitalist firms vis à vis other financial capitalist firms produce incentive for the disadvantaged financial capitalist firms to attempt to evade or eliminate these restrictions. This uneven landscape of both regulatory strictures and perquisites creates the possibility for internecine struggle among financial capitalist firms as they attempt to manipulate, evade or expand upon the pastiche of competitive advantages or disadvantages created by the regulatory framework that supports financial compartmentalization. 
Commercial banks were in many ways a privileged beneficiary of financial compartmentalization. Barriers to entry shielded commercial banking from competition from other financial capitalist firms, while interest rate controls reduced the costs associated with attracting deposits. Deposit insurance and lender of last resort support insulated commercial banks from crisis. Thanks to these advantages, as well as the exclusive and virtually free ${ }^{1}$ access to the payments system that enabled commercial banks to execute transactions, bank deposits were the instrument of choice with which the public stored their savings. This reliable access to large and inexpensive volumes of funds in the first moment of financial intermediation provided propitious conditions for the expansion of value in the second moment of financial intermediation. Thus the New Deal regulatory framework was largely credited as having contributed to a historically unprecedented era of stable and profitable American banking.

Ultimately, the profitability of commercial banking that was a cornerstone of New Deal financial reform also provoked the subversion of these financial reforms. Financial capitalists largely acquiesced to New Deal financial reforms during the tumultuous times of the great depression and the Second World War, but tensions built as the long period of relatively stable post-war prosperity continued. The New Deal supports to commercial bank profitability contributed to a growing perception that commercial banking was excessively coddled by regulatory privileges. ${ }^{2}$

\footnotetext{
${ }^{1}$ Until 1980 all costs associated with the operation of the payments system were borne by the Federal Reserve.

${ }^{2}$ Within financial circles commercial banking came to be referred to as a "3-6-3" occupation, referring to the reputation of bank executives for borrowing money from depositors at 3 percent, lending at 6 percent, and arriving at the golf course by 3 in the afternoon.
} 
Most banks were [stodgy]. They didn't make risky loans, and the "spread" between their cost of funds and the interest rates they could charge their borrowers was relatively stable at three to four percentage points, leaving a satisfactory profit margin of the bank after the deduction of "G\&A" (general and administrative) expenses and loan losses. That was, after all, the purpose of restricting entry by making charters hard to get, and limiting the interest rates bank could pay their depositors: the government wanted the bank to be stable and profitable. ... on balance banking was a steady, routine business from the Roosevelt rescue in the depression to ... 1968. (Mayer 1997. 16)

Ironically, to the extent that regulatory advantages enhanced the profitability of commercial banks, these same advantages created incentives for non-bank financial capitalist firms to find ways to compete away these enhanced commercial bank profits. Thus the success of New Deal financial reforms in enhancing the profitability of commercial banks set in motion competitive responses on the part of non-bank financial capitalist firms that would serve to undermine these reforms.

As the golden age of Keynesian welfare state capitalism matured, a number of uniquely overdetermining circumstances inflamed the competitive struggles among financial capitalists, which in turn ultimately undermined New Deal financial compartmentalization. One overdeterminant will be given particular attention, namely the acceleration of inflation during the latter part of the Keynesian welfare state era. However, a variety of other factors also played important roles in transforming financial capitalist activity, despite the fact that they are only given tangential analysis below. For example, changing regulatory and judicial interventions both reacted to and further provoked the transformation in financial capitalist activity. The evolution of computing and communications technology facilitated the creation of sophisticated financial instruments that transformed competitive struggles among financial capitalist firms. In 
general, many of the factors that contributed to the crisis of Keynesian welfare state capitalism (changing dynamics of international competition among productive capitalist firms and financial capitalist firms, the capacity of unionized workers to affect wages rates etc.) also overdetermined financial capitalist activity by exerting a variety of influences on the subsumed class struggle between productive and financial capital.

\section{$\underline{\text { Strategies Of Non-Bank Financial Capitalist Firms }}$ To Disrupt Financial Compartmentalization}

As they sought to compete away the enhanced profitability of commercial banks, non-bank financial capitalist firms were obliged to fashion their competitive strategies according to the regulatory provisions that governed the various compartments of financial capitalist activity. In general, the competitive strategies formulated by non-bank financial capitalist firms attempted to mimic the convenience (especially the capacity to write checks) and security (deposit insurance) that regulators had enabled commercial banks to offer. Non-banks were not subjected to any restrictions on the rate of return that they could offer savers, thus they could attract savings out of the commercial bank system by paying more for them. The expense of offering higher rates of return to savers could be defrayed to some extent because non-banks were exempted for some of the regulatory responsibilities that constrained commercial banks. Non-banks were not obligated by law to hold required reserves, thus a greater proportion of every dollar of savings that non-banks attracted could be used to earn some form of income. Nor were non-bank financial capitalist firms required to pay deposit insurance premiums, since they did not enjoy the protection of deposit insurance. In addition, often non-bank 
financial capitalist firms had lower $Y$ expenses in terms of non-interest costs because they did not maintain an extensive network of branch offices. Commercial banks were also subject to various regulations that impaired their competitive options. For example, regulators imposed limits on the lending that a bank could provide to an individual borrower, whereas non-bank financial capitalist firms faced no such restrictions. Nonbank financial capitalist firms were not bound by the legal prohibition on interstate banking, thus they more able to expand their operations geographically while commercial banks were confined within state lines.

In the early years of Keynesian welfare state capitalism, it was not viable for nonbank financial capitalist firms to attract savings away from commercial banks by offering rates of return in excess of New Deal interest rate controls, both because of the cost burden it would impose on non-bank financial capitalist firms and because in the early post-war days the Regulation Q cap was above the going rate paid on savings deposits. However, the acceleration of inflation during the later period of Keynesian welfare state capitalism changed this situation. In an inflationary context, New Deal interest rate controls became increasingly unattractive for depositors. Since non-banks were not bound by interest rate controls in the first moment of financial intermediation, they could outbid commercial banks for access to savings. Provided that other costs of non-bank financial capitalist firms were lower than those of commercial banks, it became possible for non-banks to pay more to attract savings and still enhance their profitability. Thanks to intensified competition between commercial banks and non-banks in this inflationary context, New Deal interest rate controls were transformed from the implicit subsidy to 
commercial banks to a competitive encumbrance. Over time commercial banks grew to abhor Regulation Q in particular, and at their insistence it was phased out with the passage of the Depository Institutions Deregulation and Monetary Control Act (DIDMCA) in 1980.

Even if non-bank financial capitalist firms were able to pay rates of return that were higher than the interest paid on deposits, the problem remained of how to offer savers a vehicle for their savings that was a close substitute for deposits. This challenge was particularly important in finding a substitute for checking accounts, since depositors who needed the ability to execute transactions were severely penalized by holding their savings in interest -free checking accounts during a period of growing inflation. Thus non-bank financial capitalist firms pursued a variety of financial innovations ${ }^{3}$ that enabled them to offer savings vehicles that mimicked the convenience and security provided by commercial bank depository accounts. By adapting the financial instruments available to savers to make them a closer substitute for deposits, and in some cases by winning for their regulatory compartment other advantages enjoyed by commercial banks, non-bank financial capitalists were able to parlay their ability to offer higher rates of return into a competitive assault on commercial banks in the first moment of financial intermediation.

\footnotetext{
${ }^{3}$ The term "financial innovation" refers to an adaptation of financial instruments or practices that enable financial capitalists to seize profit-making opportunities by evading regulatory restrictions.
} 
As non-banks succeeded in eroding New Deal compartmentalization and attracting the savings of the economy out of commercial banks, the profitability of commercial banking was ultimately undermined. As Figure 20 in chapter 5 illustrates, the Return on Assets of FDIC-member commercial banks hovered between .75\% and .88\% between 1960 and 1973, however by the early 1980s it hovered a little over .6\%. Ironically, the New Deal regulatory framework that was designed to support commercial bank profitability was increasingly regarded as a debilitating impediment to the ability of commercial banks to compete with their non-bank financial capitalist rivals. In many important instances, regulators attempted to respond to these unintentional ramifications of the New Deal regulatory structure, but their interventions often inadvertently hastened adaptations in both commercial bank and non-bank competitive strategies that further distorted and undermined New Deal regulatory principals. Confronted with these difficulties, financial regulators in the 1980s and 1990s were persuaded that the welfare of commercial banking, as well as the general prospects for economic growth and stability, demanded the dismantling of several of the preeminent components of New Deal financial compartmentalization, culminating in the repeal of the Glass-Steagall Act in 1999. 


\section{The Competitive Strategies Of Non-Bank Financial Capitalist Firms To Lure Deposits Away From Commercial Banks}

The following section has selected several examples to illustrate the strategies followed by domestic ${ }^{4}$ non-bank financial capitalist firms to out-compete the banks in the first moment of financial intermediation by undermining the various aspects of New Deal regulatory privileges enjoyed by commercial banks. In some cases these strategies involved finding an assurance of security that approximated deposit insurance, and in some cases these strategies focused on providing the capacity to execute transactions in a manner similar to checkable deposits. However, in all cases these strategies relied upon paying a higher rate of return than could be earned on bank deposits. To illustrate the progress of these non-bank financial capitalist firms in attracting savings out of the commercial banking system, the Federal Reserve's Flow of Funds data is used to provide a comparison of commercial bank deposits (checkable deposits plus small time and savings deposits) versus the savings attracted by the non-bank competitors discussed below.

\footnotetext{
${ }^{4}$ Although international competition among financial capitalists is beyond the scope of this dissertation, it should be noted that US commercial banks faced an international competitive threat in both the first and second moments of financial intermediation by the development of Euromarkets. Initially, the Eurodollar market was fueled because US dollars held abroad became more abundant as large and persistent US balance of payments deficits characterized the decline of the Bretton Woods system in the 1960s. These US dollars held abroad gave European banks the opportunity to take deposits and make loans in US dollars. Non-US banks were exempt from Regulation Q, and from other US regulatory restrictions such as American standards on required reserves and the payment of deposit insurance premiums. Thus non-US banks had the possibility of paying more to attract deposits, while making up for this additional cost by saving on other expenses incurred by US banks. As the Eurodollar market matured, it both attracted savings away from US commercial banks and made loans to US borrowers. This practice became so widespread that the phrase "round-tripping" evolved to connote funds originating in the US that were deposited in the Eurodollar market and subsequently re-lent to US borrowers.
} 
In 1971 money market mutual funds (MMMF) were introduced to compete with commercial bank deposits to attract savings. MMMFs, like other mutual funds, are financial capitalist firms that sell shares publicly and use the proceeds to buy financial assets. However MMMFs are a unique type of mutual fund in that they specialize in buying money market assets, particularly US Treasuries (although as MMMFs have evolved they may also hold commercial paper, bank certificates of deposits, banker's acceptances and repurchase agreements ${ }^{5}$ ). By operating as a mutual fund, MMMFs can aggregate smaller amounts of money to buy financial assets that are denominated in amounts too large to be practical for small savers. ${ }^{6}$ MMMFs cannot offer explicit government insurance for the savings they attract, however the default risk associated with MMMFs depends on the default risk of the financial assets that the fund holds. Since US Treasuries are regarded as having an extremely low default risk, a MMMF holding a large percentage of US Treasuries is regarded as a good substitute for placing funds in an insured deposit. Moreover, MMMFs competed with traditional bank checking accounts in that they allowed shareholders to write checks (with some restrictions) against their shares of the MMMF. MMMFs also enjoyed cost advantages over commercial banks. Since MMMFs are not legally deposits, they are not subject to reserve requirements or deposit insurance premiums.

\footnotetext{
${ }^{5}$ As the variety of assets held in MMMFs increased, this often served to allow commercial banks access to the funds intermediated by MMMFs, as when a MMMF purchases a bank certificate of deposit (see chapter seven).

${ }^{6}$ Prior to 1970 , the minimum denomination of Treasury Bills was $\$ 1,000$ which was within reach of smaller savers. However, as Regulation Q ceilings became binding, it was noticed by government officials (and the commercial bank officials that lobbied them) that savers were fleeing commercial banks to buy Treasuries. In 1970, the minimum size of Treasury bills was increased to $\$ 10,000$. This change in the denomination of Treasuries was intended to support commercial banks in their quest to attract deposits, but had the unintended effect of helping to stimulate the development of MMMFs to compete with commercial banks over access to savings. (Gart 1994, 82)
} 
By mimicking the functions of checking accounts, undercutting commercial banks in terms of the cost of attracting funds, and paying unregulated rates of interest to savers, MMMFs posed a significant competitive threat to commercial banks. In the late 1970 s, when nominal interest rates climbed considerably above the cap then set by Regulation Q, MMMFs grew dramatically. In the 10 years between 1974 and 1984 the total value of MMMF shares outstanding grew from $\$ 2.4$ billion to $\$ 232.2$ billion. As Figure 22 illustrates, MMMFs grew to control savings in the neighborhood of $20 \%$ the size of commercial bank deposits by the early 1980s. In addition, the MMMF created opportunities for other non-bank financial capitalist firms to compete with commercial banks. For example, in 1977 Merrill Lynch led the way for investment banks to utilize the MMMF to develop Cash Management Accounts (CMA). Prior to 1977, dividend and capital gains realized by investment bank customers were frequently deposited into a saving or checking account in a commercial bank. Cash management accounts were developed to allow investment banks to automatically invest these funds into a MMMF on behalf of their customers. These CMAs later evolved to offer check-writing privileges, credit cards and loans to investment bank clients. 
Figure 22: MMMF Shares Outstanding As A Percentage Of Commercial Bank Deposits,
1945-1999 Source: Flow of Funds, L.110 and L.121.

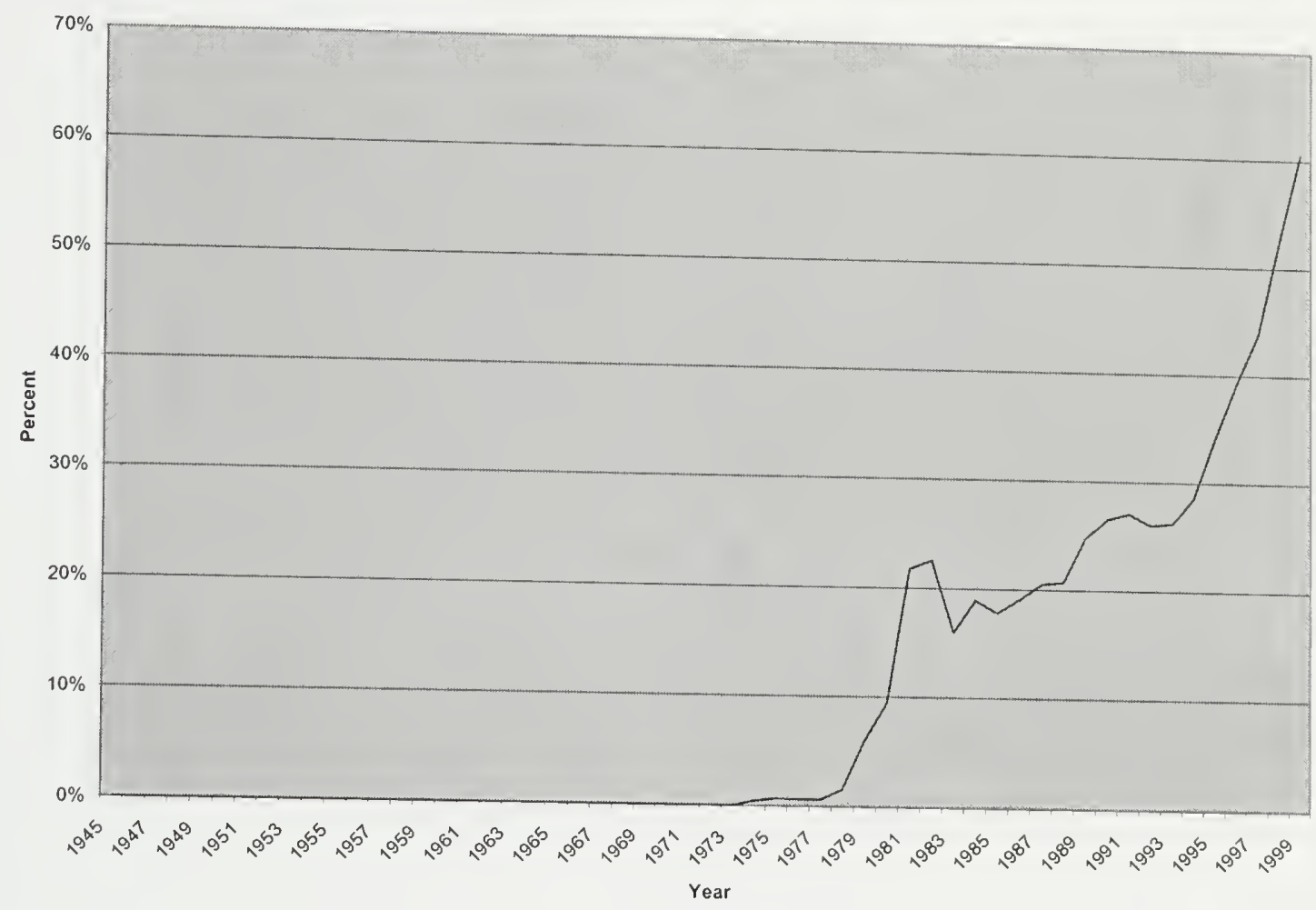

Pension funds were another type of non-bank financial capitalist firm that encroached upon commercial banks' capacity to attract deposits. Although they existed for some time prior to the 1970s, pension funds became a serious competitor to commercial banks when they surmounted their inability to offer a government-guarantee of the security of funds placed in pension funds analogous to the guarantee offered by deposit insurance. ${ }^{7}$ Prior to this time, pension funds were a problematic vehicle for workers' savings, since pension funds are often affiliated with and controlled by the employer. In the 1950s and 1960s, relatively strict vesting requirements meant that

\footnotetext{
${ }^{7}$ The growth of pension funds was also assisted by the capacity of unions to demand pension benefits during the hey day of Keynesian welfare state capitalism, among other reasons.
} 
workers frequently were obliged to forfeit pension contributions made on their bchalf, and pension funds were often so under-funded or so heavily invested in the securities of the employer that a profitability crises in the firm sponsoring the pension fund spelled disaster for workers' pensions. The scandalous termination of the Studebaker pension plan in $1964^{8}$ and other pension plan abuses prompted the United Auto Workers, as well as other union and non-union advocates of pension reform, to push for the passage of the Employee Retirement Income Security Act (ERISA) in 1974.

\section{ERISA established the Pension Benefit Guarantee Corporation (PBGC), which} dramatically increased the attractiveness of holding savings in pension funds. The PBGC afforded pension funds a security similar to that of deposit insurance, since the PBGC guaranteed the security of pensions even if the employer went out of business and pension fund assets were inadequate to meet obligations. In order to ensure that the government would not be overwhelmed by enormous liabilities from failed pension plans, ERISA held employers to higher standards in terms of funding and diversification of pensions plans. ${ }^{9}$ Both the increased perceived safety of pension plans, and the ERISA funding requirements that obliged employers to make substantial ongoing contributions to their pension funds, encouraged a great inflow of funds into pension funds. As Figure

\footnotetext{
${ }^{8}$ Studebaker retirees and retirement eligible workers over sixty years of age received their full pensions after Studebaker closed its doors. However, Studebaker workers under sixty years of age received a lumpsum payment equivalent to about $15 \%$ of the value of their pension. All workers whose pensions had not vested-including all workers under age forty - got nothing. (Wooten 2001, 731) The outcry over the situation faced by Studebaker workers compelled the United Autoworkers to push for legislative reform to protect worker's pension rights, which increased the pressure to pass ERISA in 1974.

${ }^{9}$ ERISSA also made the financing of pension plans more manageable by conferring tax benefits on employer contributions to pension plans. In addition, the earnings generated within the plans are not taxed, nor are employees taxed on any earnings until these earnings are removed from the plans (provided that the earning are not placed in some other tax-favored vehicle such as an IRA).
} 
23 illustrates, prior to 1974 , the total reserves held by pensions funds ${ }^{10}$ amounted to slightly more than $50 \%$ of the deposits of commercial banks. In the ten years following the passage of ERISA, the total reserves of pension funds grew by $145 \%$, until by 1984 savings held in pension funds have exceeded those held in deposits. By the mid 1990s two dollars were held in pension funds for every dollar held in checking or savings accounts.

${ }^{10}$ Figure 23 refers to total reserves in both private pension funds and state and local government employees pension funds. 
Figure 23: Pension Fund Total Reserves As Percentage of US Chartered Commercial Source: Flow of Funds, L.110 L.119 and L.120.

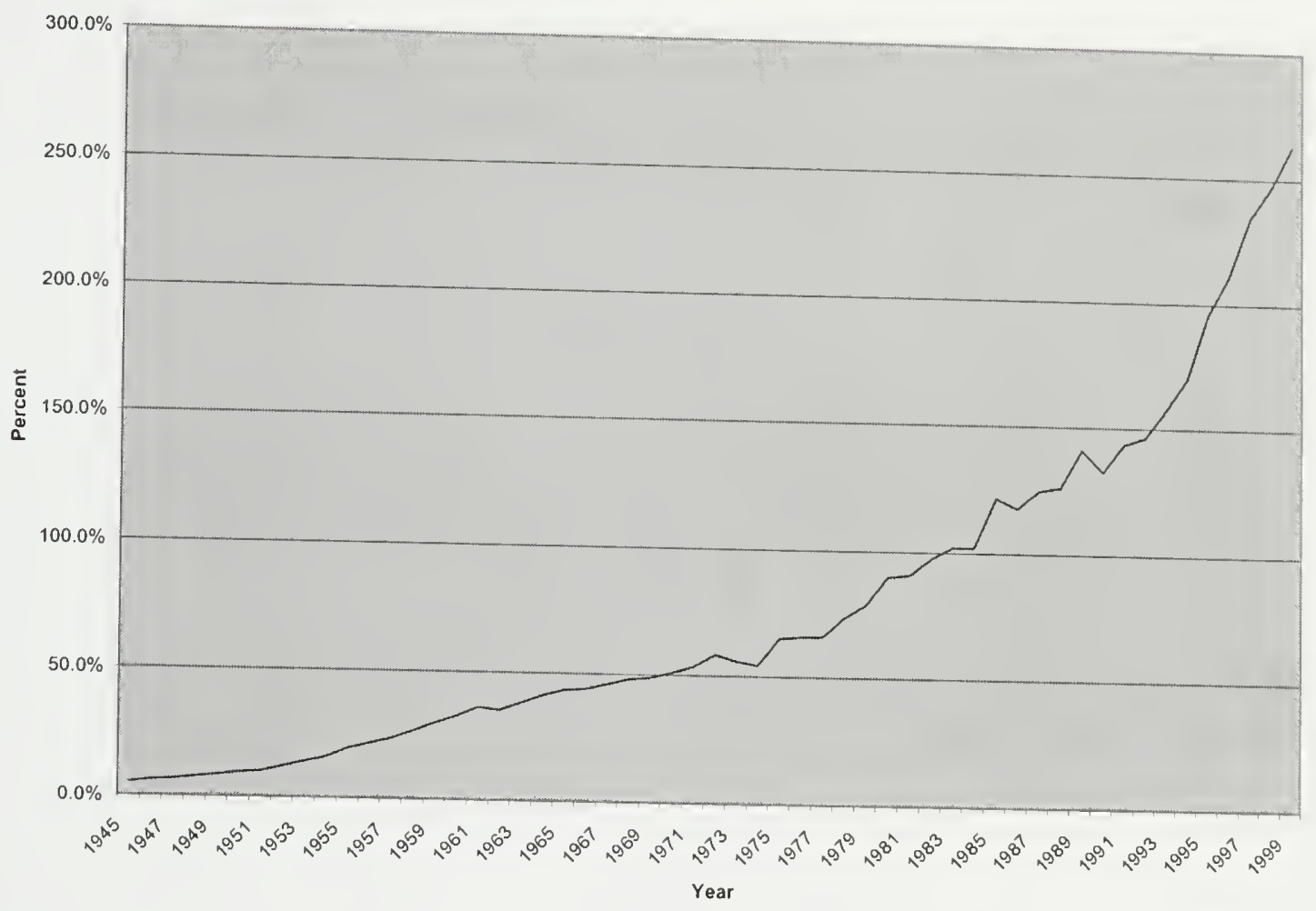

Pension plans in this era often took the form of the defined benefit plans, meaning that eligible pensioners were guaranteed a stipulated pension benefit regardless of the performance of the assets held in the pension fund. This resulted in the firm sponsoring the pension fund bearing the risk that inadequately performing financial assets might not generate sufficient funds to cover pension liabilities. Productive capitalist firms and other employers offering pension plans sought ways of shifting this risk onto pension recipients. Defined contribution plans, particularly $401(\mathrm{k})$ plans $^{11}$, became the method of

\footnotetext{
${ }^{11} 401(\mathrm{k})$ plans take their name from the section of the Internal Revenue Code that authorized their tax deferred status. Employees of "for profit employers" are eligible for $40 \mathrm{l}(\mathrm{k})$ plans, while public school, nonprofit organizations and state and local government employees all have similar defined contribution plans authorized by other sections of the IRS code. (Kimpel 1997, 271)
} 
choice to accomplish this shifting of risk back to pensioners. Unlike defined benefit plans in which retirees are paid a specified amount when they become eligible for pensions, defined contribution plans stipulate what the employer must contribute toward the pensions. The amount of the pension paid at the time of retirement will depend on the performance of the assets in the pension plan. However, defined contribution plans are not eligible for PBGC guarantee. Thus while these pension plans saved employers the expense of both making good on under-performing pension assets and having to pay premiums to the PBGC, these pension plans were less attractive in that they lacked a governmental guarantee to protect the value of the savings held in the pension. To compensate for this drawback in defined contribution plans, the federal government was prevailed upon in 1982 to provide these plans with tax deferred status. (see Kimpel 1997, 256) While retirees were denied the security of government sponsored insurance on their savings, this preferential tax treatment (which accelerated the growth of savings held in defined contribution plans) made this burden more palatable.

Given that employees bear increased risk with defined contribution plans, employees also were accorded increased capacity to direct the investment decisions of the assets in their plans. This created a tremendous opportunity for mutual funds. Mutual funds offer savers the opportunity to diversify even relatively modest savings portfolio, and they are convenient to redeem. Savers could invest funds held in these defined contribution plans into mutual funds in order to both enjoy both the tax deferred status of the defined contribution plans and place their savings in a wide variety of financial 
instruments. While prior to 1970 , mutual funds invested primarily in common stock, but they have subsequently expanded into holding virtually every type of debt and equity instrument.

Figure 24: Mutual Fund Shares Outstanding As Percentage Commercial Bank Deposits Source: Flow of Funds, L.122 and L. 123.

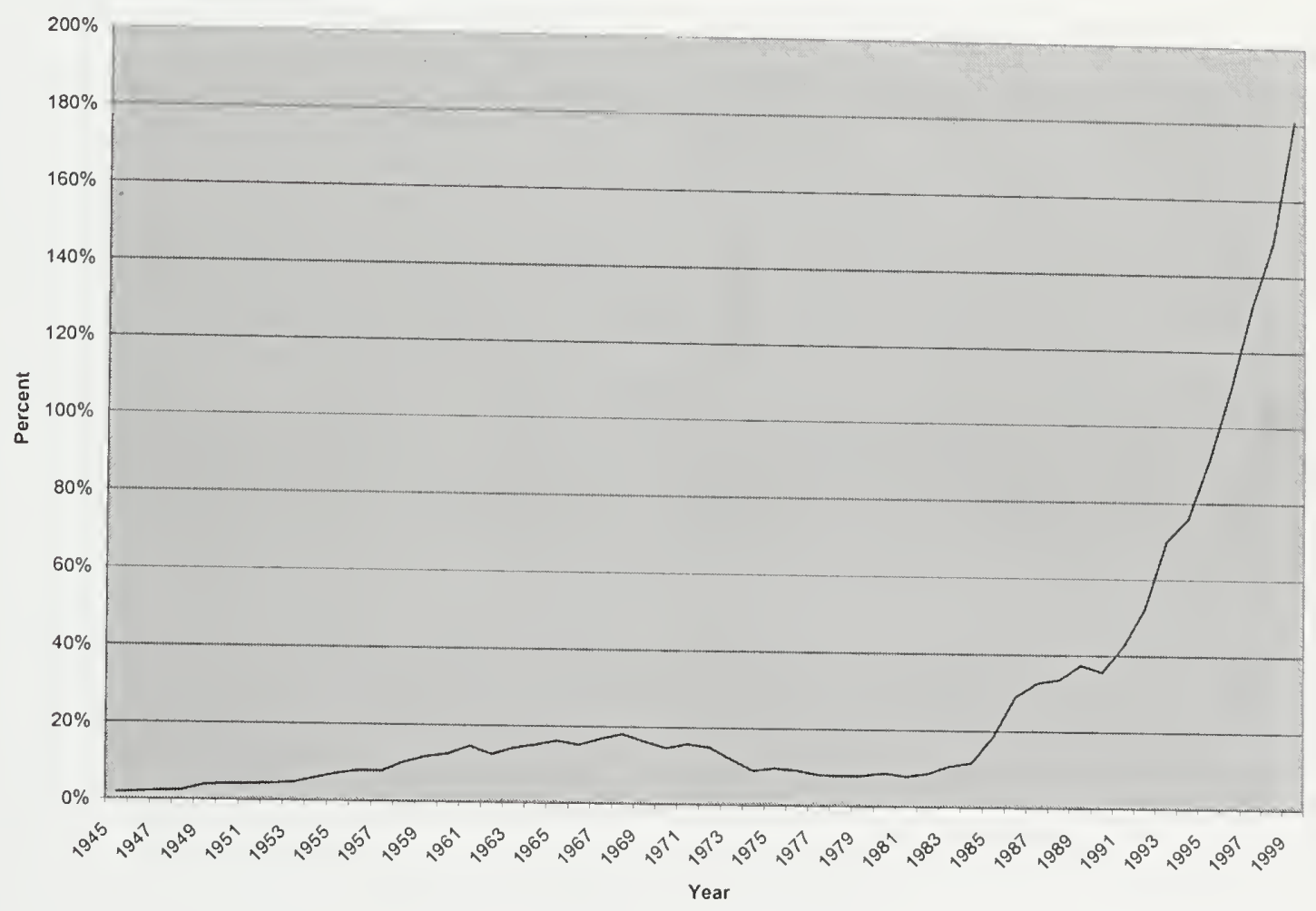

As non-bank financial capitalist firms succeeded in both paying higher rates of return than commercial banks, and offering savings vehicles that approximated the security and accessibility of deposits, these competitive strategies began to have startling impact on the ability of commercial banks to attract funds via deposits. This impact is illustrated in Figure 25, which displays the percentage of the total financial assets of households, non- 
profit organizations and non-financial corporate business ${ }^{12}$ that are held in various forms. The category "deposits" displayed in this graph is an overstatement of deposits as we have defined them in our class analysis of commercial banking. Ideally we would wish to display checking and savings deposits, however the Flow of Funds categories are such that the line labeled "deposits" on Figure 22 unfortunately includes both currency and time deposits (such as the certificates of deposit that will be discussed in chapter 8), as well as our desired categories of checking and savings deposits. Despite the exaggeration of the size of deposits in the Figure 25, it provides an indication of loss of commercial banks' hegemonic command over the first moment of financial intermediation.

\footnotetext{
${ }^{12}$ Non-financial corporate business is used here as the best approximation of productive capitalist firms offered within the flow of funds categories.
} 
Figure 25: "Deposits", MMMFs, Pension Shares And Mutual Fund Shares As A

Percentage Of The Total Financial Assets Of Households, Non-Profit Organizations And Non-Financial Corporate Business

Source: Flow of Funds, B.100 and B.102.

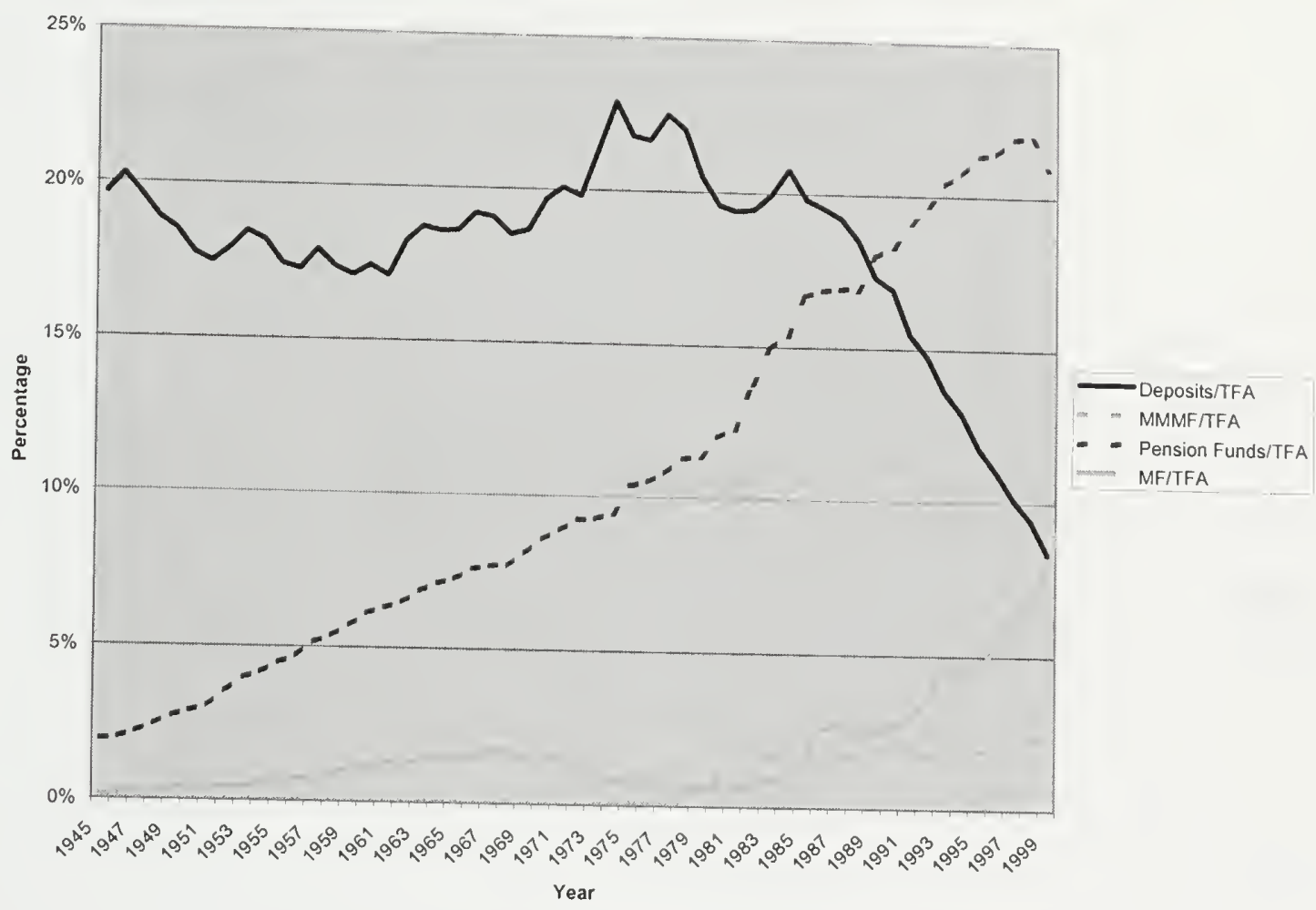

Bellum Financus And Its Impact On The Diversification Of Class Processes Within The Firm

The success of non-bank financial capitalist firms in their competitive struggles to attract savings away from commercial banks in the first moment of financial intermediation created conditions that transformed financial capitalist activity in the United States. With more funds at their disposal, and the capacity to provide both loans and purchase equities in the second moment of financial intermediation, non-bank financial capitalists were in a position to transform subsumed class struggle among 
financial capitalists. In terms of the provision of loans, commercial banks were being increasingly supplanted as the major provider of credit. This trend is illustrated in Figure 26 , which displays the percentage of total credit market debt ${ }^{13}$ provided by commercial banks, MMMFs, pension funds and mutual funds over time. Until 1980, commercial banks provided in excess of $25 \%$ of all credit market debt, while by the time of the elimination of Glass-Steagall in 1999, commercial banks provided only $16 \%$ of credit market debt. Unlike commercial banks, non-bank financial capitalist firms were not restricted to the provision of loans in the second moment of financial intermediation. In the later part of the 1990s, pension funds held over half of their total financial assets as corporate equities, while for mutual funds this ratio was close to three quarters (Flow of Funds, L119, L120 and L122).

\footnotetext{
${ }^{13}$ Total credit market debt held by these various entities described in figure 26 excludes mutual fund shares, which may affect the total of credit market debt indirectly provided..
} 
Figure 26: The Total Credit Market Assets Of Commercial Banks, Pension Funds, MMMFs And Mutual Funds Relative To Total Credit Market Assets ${ }^{14}$

Source: Flow of Funds, L.1.

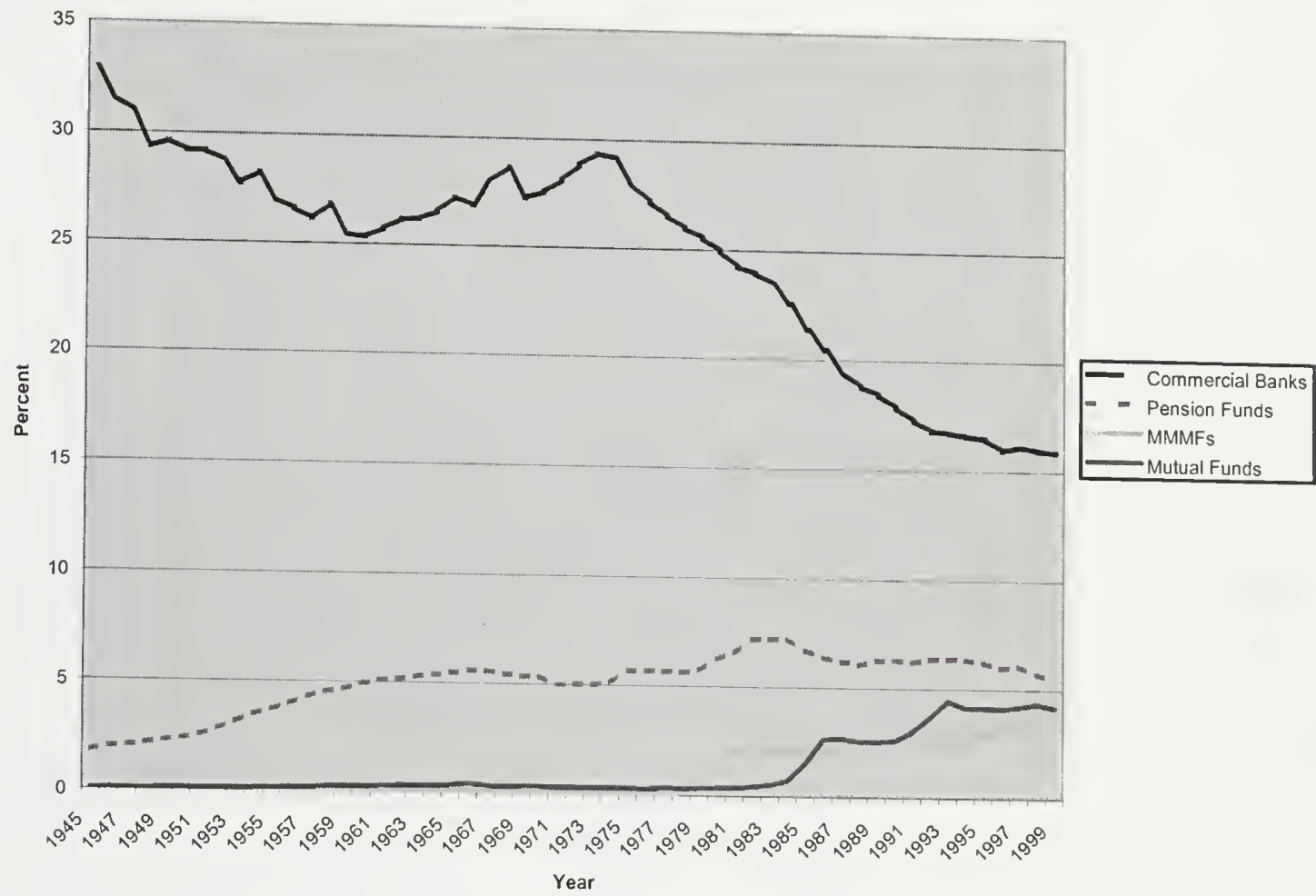

This displacement of commercial banks in both moments of financial intermediation was a dramatic departure from the assumptions about financial capitalist activity made by the architects of the New Deal financial regulatory framework. New Deal financial reform was predicated on non-banks having limited access to savings (since they were prohibited from accepting deposits) but unimpeded ability to provide both debt and equity capital, while commercial banks had access to deposits but were unable to be involved in the provision of equity capital. Now non-banks had both increasing access to the economy's savings in the first moment of financial intermediation, while maintaining

\footnotetext{
${ }^{14}$ Total credit market assets of commercial banks include US government securities, municipal securities corporate and foreign bonds as well as total loans. They exclude any holdings of corporate equities and mutual funds.
} 
their ability to engage in both debt and equity capital provision in the second moment of financial intermediation. This new situation produced a variety of strains on the New Deal financial regulatory framework. Since non-bank financial capitalist firms are less stringently regulated that commercial banks, the pool of savings that was intermediated outside of the commercial banking system could be used in creative ways not foreseen by the architects of New Deal financial reforms. Thus the new channels through which savings were intermediated produced (and were further accelerated by) the introduction of new financial innovations, which in turn further eroded the coherence of New Deal financial reforms.

With a growing pool of savings at their disposal, non-bank financial capitalist firms had the opportunity to challenge some of the competitive advantages that still remained with commercial banks. The ability of non-banks to advance money capital via securities purchases is in some ways less flexible than commercial bank lending, since banks could lend to consumers and other entities that could not issue securities. Commercial banks also had informational advantages over non-banks in assessing the future prospects of firms in need of money capital. Over time, progress in computing and communications technology substantially eroded this informational advantage. Non-banks increasingly developed financial innovations that would both take advantage of this technological progress, and that would enhance the flexibility of their activities in the second moment of financial intermediation. As non-bank financial capitalist firms overcame these disadvantages, a host of new financial developments was unleashed which further undermined New Deal compartmentalization. 
Instead of relying on the purchase of debt or equity securities in the second moment of financial intermediation, non-bank financial capitalist firms have the option of advancing money capital via the commercial paper market. Commercial paper is an uncollaterialized short-term debt that can be a good substitute for the short-term borrowing from commercial banks by productive capitalist firms (and other issuers). Provided that commercial paper has a maturity of less than ninety days, it is not legally considered to be a security and is not subject to the many provisions of the Securities Act of 1933. Because commercial paper does not have to be registered with the Securities Exchange Commission as a public offering, it is not required to meet the disclosure standards of other securities, and no regulatory body is charged with the surveillance of trading practices in the commercial paper market. (d'Arista and Schlesinger 1993, 168) However, the commercial paper market has historically been fraught with difficulty. Given that commercial paper is not secured by any specific asset, and that commercial paper markets lack many of the safeguards required in securities markets, the commercial paper market has periodically been thrown into crisis. A default by a commercial paper issuer can cause a panic analogous to a bank run that shuts down the supply of funds into the commercial paper market. Since commercial paper is a short term instrument that must be constantly rolled over, commercial paper issuers are obliged to collectively run to other sources of funds if lenders flee the commercial paper market. This dynamic frequently debilitated the commercial paper market prior to the 1970s, and made commercial paper a problematic substitute for traditional securities both for suppliers of money capital and for firms in need of money capital. ${ }^{15}$

\footnotetext{
${ }^{15}$ The commercial paper market is most attractive to issuing firms with good credit ratings, since perceptions of a borrower's capacity to repay its loans assumes heightened importance given that
} 
Following a convulsion in the commercial paper market in $1970^{16}$, this obstacle to the stability of the commercial paper was surmounted, ironically with the assistance of commercial banks (see chapter 8). Commercial banks were enticed to earn fee income by providing lines of credit to support the issuers of commercial paper. In the event that doubts arise concerning the capacity of the issuer to repay its commercial paper, the line of credit can be activated so that the issuer can honor its debts. This contrived substitute for lender of last resort support provided a backstop to deter panics in the commercial paper market. With this support in place, the commercial paper market grew enormously as mutual funds, pension funds and many others came forth as eager purchasers of commercial paper. (Chapter 8 points out the irony that, as the commercial paper market became an important source of funds, commercial banks themselves issued commercial paper in order to gain access to the funds that were no longer flowing to the commercial banking sector in the form of deposits.) While in 1970, only commercial paper outstanding constituted only about $10 \%$ of the commercial bank loans outstanding, by the late 1990 s commercial paper outstanding constituted $40 \%$ of the commercial bank loans outstanding.

commercial paper is not backed by collateral. Thus firms that access funds in the commercial paper market are more sensitive to changes in how they are evaluated by credit ratings agencies, since a negative credit rating can dry up their access to funds on this market. Thus while the commercial paper market enhances the capacity of productive capitalist firms (and other firms) to access funds, it also adds new sources of instability, since they are increasingly vulnerable to negative market perceptions that may plunge them into a liquidity crisis.

${ }^{16}$ In 1970 , Penn Central Railroad defaulted on $\$ 83$ million in commercial paper, which provoked a virtual seizing up of the commercial paper market, even for solvent borrowers. (Hayes 1987, 87) 
Figure 27: Commercial Paper Outstanding As A Percentage Of Total Commercial Bank Loans Outstanding, $1970-1999$.

Source Flow of Funds L.208 and L. 110.

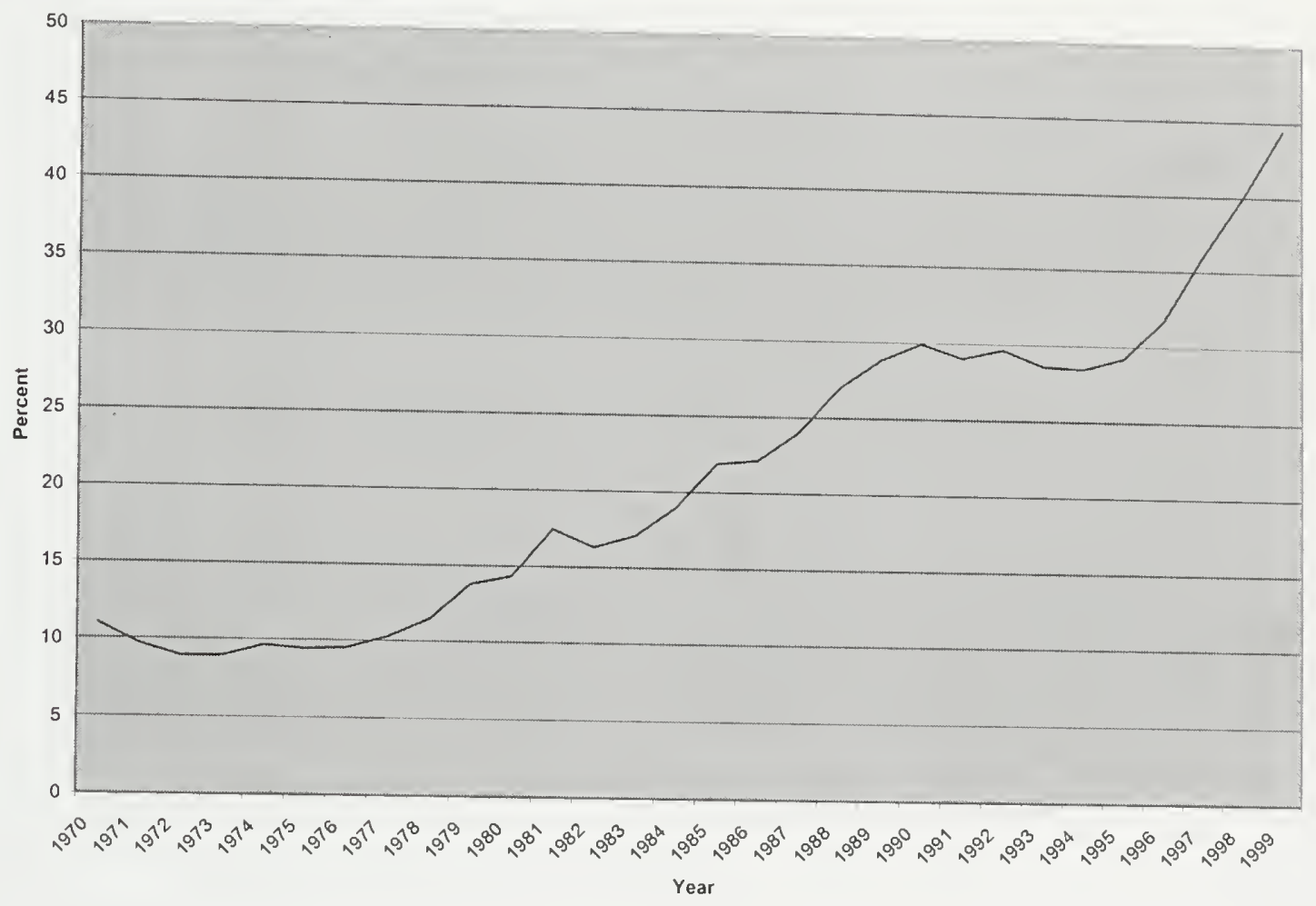

As the commercial paper market provided a conduit for the savings intermediated outside of commercial banks, new opportunities were created that further transformed financial capitalist activity. The finance company was one type of non-bank financial capitalist firm that seized on commercial paper to promote this transformation. Finance companies (such as Household Finance Company) have long existed as a type of financial capitalist firm that acquires funds and makes loans, often to consumers. Once the commercial paper market flourished in the 1970s, finance companies could sell commercial paper (although they may also issue securities and other instruments), and use the proceeds to make both subsumed class loans to productive capitalist firms and 
non-class loans to other types of firms, consumers and other entities. This freed finance companies of dependence on commercial bank loans as a means of accessing funds for subsequent re-lending. Finance companies are not highly regulated, and they do not have to comply with the various soundness regulations, such as capital or liquidity requirements, limits on loans to individual or related borrowers, or limits to loans to parents or affiliates that affect commercial banks. (d'Arista and Schlesinger 1997.489) Thus finance companies are virtually free to raise funds and hold assets in any manner that they choose, and unlike commercial banks they are able to cross state lines. 
Figure 28: Total Financial Assets Of Finance Companies As A Percentage Of Total Financial Assets Of US-Chartered Commercial Banks, 1970-1999

Source: Flow of Funds, L.110 and L.128.

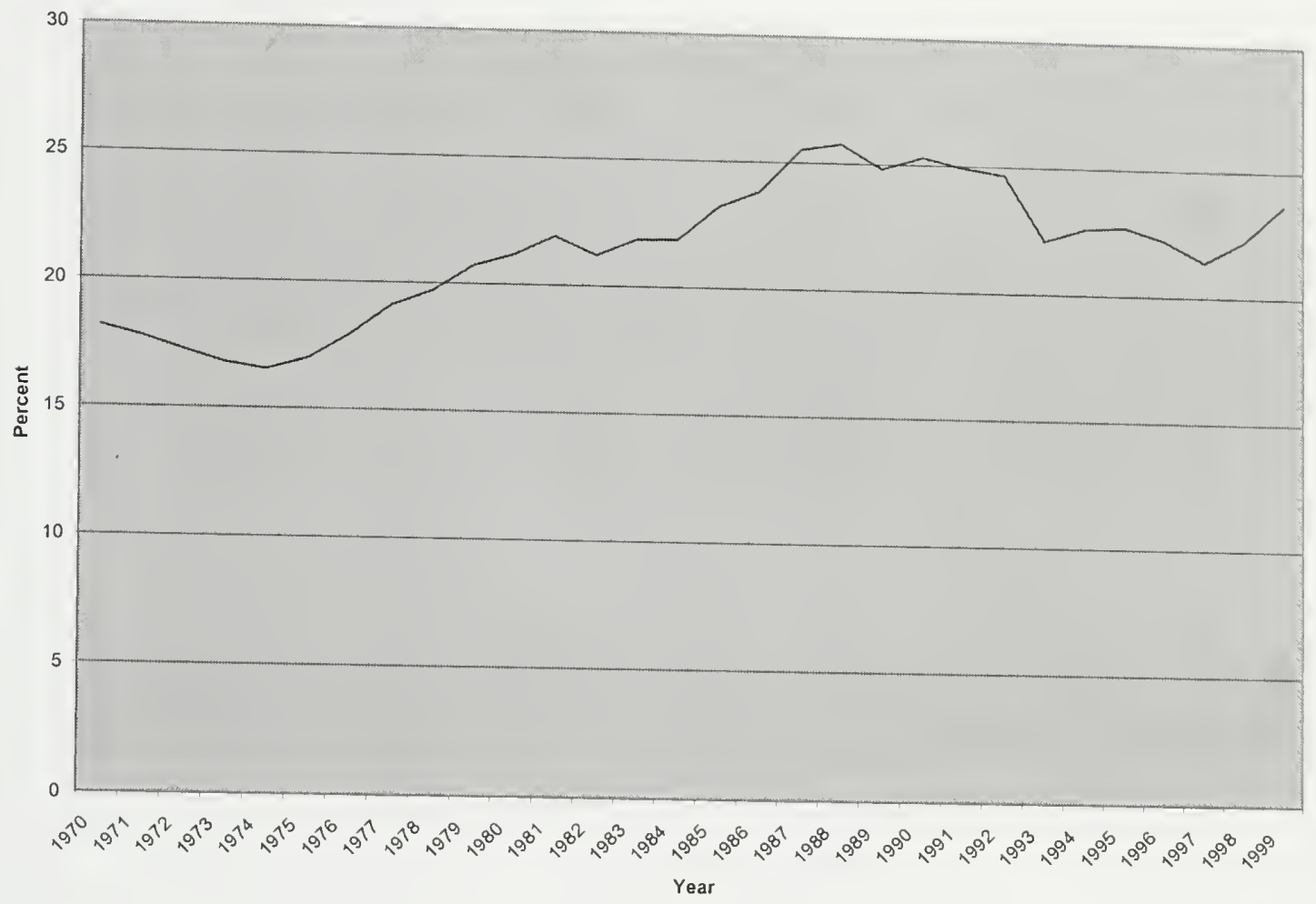

The availability of funds on the commercial paper market (and later other

\section{financial innovations such as securitization ${ }^{17}$ ) provided opportunities that would}

transform the class character of the firm. Productive capitalist firms and merchant

\footnotetext{
${ }^{17}$ The process of securitization converts a portfolio of illiquid loans into securities that are backed by those loans. Thanks to the development of sophisticated computing technology, loans of a given risk profile are gathered into a pool, and shares of the cash flow emanating from this pool of receivables are sold as securities. The security sold as a result of this process is referred to as an asset-backed security (ABS). The risks posed by the loans in the pool are typically defrayed by some form of third party insurance. ABS provides some advantages over the commercial paper, in that short-term commercial paper must be frequently rolled over, which may prove difficult if the parent company is experiencing difficulties. ABSs are removed from the books of the issuer, thus freeing up funds to advance new loans. In addition, the process of securitization has "propertized" the right to services loans. Since the loans the underlie these securities can be divorced from the company which originated them, the "servicing" of loans, meaning the collection of payments and the distribution of revenues to the holders of the ABS now exists as an distinct activity. Creators of ABS may earn income by selling the rights to service the ABS pool to a third party. Thus potentially a commercial bank may earn fee income by gaining the right to service the securitized car loans of a automotive finance company.
} 
capitalist firms could access this pool of funds by developing finance company subsidiaries, dubbed "captive" finance companies. ${ }^{18}$ Thus prominent productive capitalist firms, like General Electric and the North American automobile manufacturers, could now both appropriate surplus value and earn subsumed class and/or non-class revenue by engaging in money-lending financial capitalist activity. While the financial capitalist activities of captive finance companies were initially closely connected to the surplus value appropriating divisions of the parent diversified capitalist firm, captive finance companies, such as those associated with General Electric, have flourished to the extent that they are engaged in lending to entities that are not immediately connected with the other activities of the other subsidiaries of the parent company.

While we have heretofore conceived of the relationship between productive and financial capital as an arms length subsumed class relationship in which financial capital supports productive capital by providing funds for accumulation, this transformation in the class processes occurring within a diversified capitalist firm provides new ways in which financial and productive capital may interact. Surplus value appropriation may be supported to the extent that the financial capitalist subsidiary makes loans to facilitate the purchase of the commodities produced by the productive capitalist division of the parent company. ${ }^{19}$ The capacity to combine financial and productive capitalist activity also offers the opportunity to package productive capitalist and financial capitalist activities in

\footnotetext{
${ }^{18}$ Many firms, such as General Electric, had finance companies that predate the development of the commercial paper market, but they were much less important prior to the accessibility of funds that the commercial paper market provided.

${ }^{19}$ A captive "sales" finance company will advance these loans to consumers, while a "business" finance company will engage in money-lending (via loans or more circuitously via such practices as factoring or leasing equipment) to other productive and unproductive capitalist firms.
} 
ways that disguise the extent to which buyers are paying for the commodity purchased or for the financing to purchase the commodity. Thus the parent company's productive capitalist division may be assisted in their competition in product markets if the finance company can provide financing to consumers at rates that compensate for substandard commodity price or quality. Alternatively, the advantages of diversified capitalist firms in product markets may compel customers to accept financing on disadvantageous terms. A second way in which productive and financial capitalist activities may be combined concerns the provision of funds to suppliers of raw materials or equipment required in production. A diversified capitalist firm may provide money capital to suppliers of "c" goods in return for pricing or other concessions on these commodities, or alternatively the diversified financial capitalist firm may provide financing to suppliers in return for below market subsumed class payments in exchange for, say, exclusive access to raw materials.

While Hilferding's Finance Capital had foreseen the blending of productive and financial capitalist activities under the dominance of financial capital, the development of the diversified capitalist firm represents the blending of productive and financial capitalist activities with no necessary relationship of dominance. While considerations may be such that the financial capitalist activity of the diversified capitalist firm might be carried on to promote profitability of the firm's productive capitalist activities, conditions may also develop to produce the opposite, namely a diversified capitalist firm that operates such that revenues from financial capitalist activity dictates the behavior of productive capitalist subsidiaries. The detailed class analysis of any diversified capitalist firm will be required to judge whether, in any uniquely overdetermined context, 
productive capitalist or financial capitalist imperatives are in the ascendancy. Moreover, as the overdetermined context unfolds, it is entirely possible that a diversified capitalist firm will change its relative emphasis of its financial and productive capitalist activities

The organizational structure of the diversified capitalist firm also presents the possibility that this firm will exhibit subsumed class struggle internal to the firm. In the event that, for example, a finance subsidiary provides money capital to a productive capitalist subsidiary of the same parent diversified capitalist firm, there may be conflicts concerning the financial capitalist and productive capitalist agendas animating the diversified capitalist firm. Even if this direct subsumed class relationship doesn't exist internal to the firm, it may be that the condition of existence for profitability in the financial capitalist subsidiary of the diversified capitalist firm are at odds with the condition of existence for profitability in the productive capitalist subsidiary. To the extent that diversified capitalist firms become the predominant organizational form, this adds new complexity to generalizations about "financial capital" and "productive capital". Productive capital and financial capital must be understood as processes to expand value rather categories under which capitalist firms can be neatly classified. The name of a firm (with its productive of financial capitalist connotations) or even a cursory assessment of where to garners the majority of its revenues, may not suffice to justify the categorization of such firms as productive or financial capitalist. 
Steagall regulatory framework. As financial capitalist activity migrated into diversified capitalist firm and other organizational forms that were much less heavily regulated than traditional financial capitalist firms, it became possible to subvert New Deal financial compartmentalization in ways that were forbidden to financial capitalist firms that were

regulated explicitly according to the New Deal categories of financial capitalist activity. For example the various financial subsidiaries of General Electric increasingly engaged in money lending, the provision of insurance, and securities dealings that financial capitalist firms regulated under New Deal financial compartmentalization were forbidden to blend. This created further pressure for regulators to relax the regulatory barriers that compartmentalized financial capitalist activity. However, the challenge remained to incorporate commercial banking into diversified capitalist firms, or for that matter, into diversified financial capitalist firms.

\section{Commercial Banks And The Diversification of Capitalist Firms}

New Deal financial reforms and the Bank Holding Company Act were intended to prevent the blending of commercial banking with other financial capitalist or productive capitalist activity. By preventing the interconnections between commercial banking and other capitalist activities in diversified firms, the commercial banking system was shielded from the possibility that these interconnections might induce commercial banking crises. For example, the separation of commercial banking from other capitalist activities prevented the possibility that a commercial bank subsidiary of a diversified capitalist firm might fail due to unwise loans made to productive capitalist or financial 
capitalist subsidiaries. This segregation of commercial banking away from other capitalist activity was intended not only to enhance the stability of the commercial banking system as a whole, but to contain the moral hazard dilemma inherent in commercial banking. Both via lender of last resort support and via deposit insurance, the state is exposed to the possibility of bailing out commercial banks in crisis. Thus the state is concerned to limit the intensification of the moral hazard dilemma, lest it find itself playing an indirect role of lender of last resort to all sorts of capitalist activities that have been positioned to threaten the solvency of commercial banks. By shielding commercial banking from participation in diversified financial capitalist firms or diversified capitalist firms, the state sought to avoid the possibility that its responsibilities to maintain the stability of the commercial banking sector might be imposed upon to handle difficulties that emanated from beyond the commercial banking system.

However, the intensification of this moral hazard dilemma by blending nonbanking capitalist activities with commercial banking may be a powerful strategy to enhance capitalist profitability. A capitalist firm that enjoys even the possibility of state support in the event of crisis has a higher tolerance of risk, and thus can pursue strategies with a higher risk/expected return tradeoff. Moreover, positioning capitalist activities within a commercial bank, or sufficiently nearby that the moral hazard is intensified, can have important cost savings. As Alan Greenspan reasoned in the late 1990s, the cost of funds used to engage in any activity housed within a commercial banks is moderated because of this implicit support of the state. ${ }^{20}$ In recognition of the importance of this

\footnotetext{
20 "' [I]f you have a new power and you can stick it in the bank, you will do so, because the cost of capital is lower of the bank'. But the reason for the reduced costs, Greenspan insisted, was the implicit subsidy given
} 
safety net, many of the financial innovations discussed in this chapter were motivated to mimic lender of last resort support or deposit insurance. However, this mimicry was always imperfect. Any substitute for lender of last resort support, such as a line of credit, is finite in the emergency funds it provides and is ultimately only as reliable as the commercial bank that backs it. By contrast, the emergency assistance provided to commercial banks extends to the full capacities of the Federal Reserve system, which is the entity that creates money itself. Moreover, any source of crisis support devised by non-bank financial capitalist firms comes at a price (as when a line of credit is purchased for a fee), while commercial banks are eligible for lender of last resort support just by virtue of being commercial banks.

Commercial banks thus have a powerful incentive to engage in other types of capitalist activity in hopes of that their lender of last resort will translate into competitive advantage in these non-banking pursuits. However, the Bank Holding Company Act (BHCA) of 1956 (see chapter 5) was intended to prohibit just such an attempt by a commercial bank to engage in diversified financial capitalist activities, or in the mixing of productive and financial capitalist activity. In the 1960s, commercial banks attempted to evade these restrictions on the blending of commercial banking with other capitalist activities by attacking the definitions employed in the Act. While the BHCA defined a bank holding company as a firm that controlled two or more banks, commercial banks contended that if their holding companies controlled only one bank, that they should be exempt from the constraints of the BHCA. The resulting "one-bank holding company" 
flourished until Congress acted to address this loophole that was creating opportunities for commercial bank involvement in diversified capitalist firms. In 1970 the Holding Company Act Amendments were passed which allowed bank holding companies to exist, however their non-banking activities were to be "closely related to banking".

While this legislation limited commercial bank's ability to initiate diversified capitalist firms, it had unintended consequences that assisted the formation of diversified capitalist firms in other respects. The 1970 legislation defined a commercial bank as a firm that 1) accepts demand deposits and 2) makes commercial loans. In an attempt to subvert this prohibition on the blending of commercial banking with other capitalist activities within a holding company structure, legal arguments were advanced to attack this legislated definition of a bank. Lawyers successfully reasoned that a firm that makes commercial loans without taking deposits, or takes deposits without making commercial loans, is not legally a bank. Thus the "non-bank bank" was born. In 1980 Gulf and Western's finance company subsidiary, Associates First Capital Corporation, acquired Fidelity National Bank. The Comptroller of the Currency was persuaded that the resulting firm need not be classified as a bank in the meaning of the BHCA so long as it was divested of its commercial loan portfolio. The new non-bank bank was subject to the same reserve requirements and examinations as regular banks, and remained eligible for access to the payment system and for FDIC insurance. (see Vietor 1987, 49-50) Direct access to the payments system proved to be an enormous competitive benefit for nonbank banks, since it enabled them to support the credit card and consumer lending activities of the parent corporation, or in the case of Merrill Lynch, it could execute its 
cash management account transactions. This offered substantial savings for the parent company, because without access to the payments system transactions would have to be cleared via a commercial bank for a fee. However, the parent firm was able to engage in productive and merchant capitalist activities, as well other financial capitalist activities such as corporate securities underwriting and insurance brokerage.

A battle ensued as the Federal Reserve moved to broaden the definition of a bank (including a decision in 1984 to define the purchase of commercial paper as constituting a commercial loan). In 1986 the United States Supreme Court struck down the changes in the definition of commercial banks that the Federal Reserve had imposed to address the growth of non-bank banks, and within weeks almost a hundred applications to form nonbank banks were filed. Insurance companies, mutual funds, brokerages and even merchant capitalist firms such as Sears, K Mart and Montgomery Ward began to run nonbank banks in competition with commercial banks. ${ }^{21}$ To contain this rapid transformation of financial capitalist activity, and the blending of productive, merchant and financial capitalist activity, the Competitive Equality in Banking Act (CEBA) was passed in 1987. Although the CEBA is primarily remembered for its intervention in the unfolding Savings and Loan crisis, the CEBA placed more stringent requirements on non-bank banks. The CEBA obliged the companies affiliated with non-bank banks to face the same regulations as bank holding companies. Although existing non-bank banks were grandfathered, their asset growth was limited to 7 percent annually and the creation of new non-bank banks was prohibited for one year. (Gart 1994, 88-9)

\footnotetext{
${ }^{21}$ As we shall see in chapter seven, even commercial banks sought to establish non-bank banks.
} 
Faced with both the subversion of both New Deal financial reforms and the erosion of the principle of the separation of commerce and finance generally, CEBA was compelled to confront the increasingly thorny issue of how to define a commercial bank in the context of the dramatic transformation of financial capitalist activity. In an implicit acknowledgement of the impossibility of achieving any definition which would relate commercial banking to its role in financial intermediation, the CEBA abandoned the attempt to define a commercial bank in terms of its financial capitalist activities. Instead, the CEBA proclaimed that a bank is defined as a member of the FDIC. This definitional change represents an admission that the metamorphosis in financial intermediation had rendered conceptualizations of financial capitalist activity based on norms associated with New Deal compartmentalization increasingly obsolete.

\section{The Repeal of the Glass-Steagall Act}

Throughout the late 1980s and early 1990s New Deal compartmentalization was becoming increasingly unsustainable. Commercial banks lobbied and fought legal battles with a variety of regulators to expand their capacity to engage in multiple financial capitalist activities. While a large number of state and federal legal and regulatory battles facilitated this erosion of New Deal compartmentalization, only a few of the highlights can be mentioned here. In 1986, the Federal Reserve Board, was prevailed upon to reinterpret Section 20 of the Glass-Steagall Act which prohibited commercial banks from being "engaged principally" in securities business. The Federal Reserve decided that banks could have up to 5 percent of gross revenues from investment banking activities. 
Thereafter ensued numerous battles concerning the interpretation of the phrasc "cngaged principally", and over time the 5 percent limit was increased and the types of investment banking activities that were permissible were broadened until by 1996 , bank holding companies are permitted to own investment bank affiliates with up to 25 percent of their business in securities underwriting. In 1997 Banker's Trust became the first US bank to purchase an investment bank, and in 1998 the Travelers Citicorp merger was announced. Since the Travelers Citicorp merger blended insurance, commercial banking and investment banking, it was still in violation of the Glass-Steagall Act. The merger would have required the divestiture of some lines of business in the new firms within 2 years, however Congress succumbed to intense lobbying and the Glass-Steagall Act was repealed in 1999.

With the passage of the passage of the Gramm-Leach-Bliley Act of 1999 (the "financial modernization act"), the Glass-Steagall Act was repealed. This legislation created a new entity, referred to as a financial holding company (FHC), which could combine commercial banking, investment banking, insurance provision and other financial capitalist activities within one holding company structure. This facilitated a round of mergers and acquisitions amongst large financial capitalist firms in which large commercial banking could again be blended with investment banking, insurance provision and a variety of other financial capitalist activities. Thus the landscape of financial capitalist firms was again transformed in a manner reminiscent of the pre-Ncw Deal era, when in the context of a stock market bubble financial capitalist firms rushed to blend a variety of financial capitalist activities. 
The Gramm-Leach-Bliley Act did maintain some obstacles to the financial holding companies' engaging in productive capitalist activity. While financial holding companies are permitted to take a controlling interest in non-financial enterprises ${ }^{22}$, these investments are not to be held indefinitely. ${ }^{23}$ Moreover, the financial holding company is not intended to "routinely manage or operate" any non-financial firm in which it invests. (see Kroszner, 2000) In due course, these restrictions on creating diversified capitalist firms are being challenged by financial holding companies. At the same time, other firms such as Wal-Mart are making inroads into banking in certain states while escaping Federal Reserve oversight since they are not structured as financial holding companies.

\section{Evaluating New Deal Financial Reforms In Light Of Their Keynesian Motivations}

The dissertation has presented the case that the New Deal financial reforms were motivated by a Keynesian agenda focussed on the joint objectives of reducing the subsumed class payment required to secure money capital and stabilizing the commercial banking system by enhancing commercial bank profitability. In particular, the argument has been presented that financial compartmentalization one of the means by which these joint objectives were pursued. Financial compartmentalization was analyzed as a means to exert downward pressure on the subsumed class payment required to secure money capital by enhancing subsumed class struggle in the second moment of financial

\footnotetext{
${ }^{22}$ Subject to some restrictions, such as the requirement that total holdings cannot exceed $\$ 6$ billion or $30 \%$ of Tier 1 capital without Federal Reserve approval.

${ }^{23}$ The Act stipulates only that such investments can be "held for a period of time to enable the sale or disposition thereof on a reasonable basis consistent with the financial viability of the [investment]". (Kroszner 2000,1)
} 
intermediation. This was matched by the moderating effects of compartmentalization on competition in the first moment of financial intermediation, in order that commercial banks might gain access to funds cheaply and thereby enhance their profitability despite more vigorous subsumed class struggle in the second moment of financial intermediation. This chapter traces the ways in which the success of financial compartmentalization unleashed pressures to subvert financial compartmentalization, culminating in the complete repudiation of this regulatory principle in the repeal of the Glass-Steagall Act in 1999. However, little has been said throughout the dissertation concerning how the rise and decline of financial compartmentalization impacted these joint objectives of low subsumed class payments for access to money capital and stability in the commercial banking system. Chapter 8 will speak to the issue of the stability of the commercial banking system over this time period, however some comments on the costs of obtaining money capital are in order here.

Thus far the question has not been posed as to whether New Deal financial reforms succeeded in producing a low subsumed class payments for access to money capital. Nor have we considered whether the undermining of the New Deal reforms translated into an increase in this subsumed class payment. These questions have not been posed since the assertion that the subsumed class payment required to obtain money capital is overdetermined precludes establishing a cause and effect relationship between the measures imposed by New Deal financial reforms and the subsumed class payment that prevailed. We argue that the intensification of subsumed class struggle among financial capitalist firms was promoted by the abolition of diversified financial capitalist 
firms. However, at the same time the contradictory possibility exists that compartmentalization might exert an upward pressure on the cost of securing savings in the first moment of financial intermediation might translate into upward pressure on the size of this subsumed class payment. Since the design of compartmentalization contained contradictory implications, it is impossible to conclude what the "success" of this reform would produce in terms of its net effect on the subsumed class payment required to secure money capital. Moreover, these particular reforms are not the only determinant of this subsumed class payment. For example, subsumed class struggle among financial capitalists were overdetermined by numerous factors, such as the imposition of constraints concerning international capital flows, the dynamics of stock markets and business cycles, the evolving tax treatment of debt verses equity capital and so on. In addition, this subsumed class payment was overdetermined by subsumed class struggle between productive and financial capital, which in turn is shaped by factors such as the extent of retained earnings in productive capitalist firms, varying tax provisions, and so on.

Nor can an overdeterminist analysis conclude that, as financial compartmentalization set in motion its own negation, this translated as an unambiguous increase in the subsumed class payment required to secure money capital. Arguably the reemergence of diversified financial capitalist firms again posed the possibility that such firms could manage subsumed class struggle in the second moment of financial intermediation in order to promote upward pressure on the subsumed class payment required to secure money capital. However, the overdetermined context in which these 
diversified financial capitalist firms re-emerged differed vastly from the context that prevailed in earlier encounters with "finance capital" à la Hilferding. For example, while some financial innovations facilitated the re-emergence of diversified financial capitalist firms, they also produced opportunities for productive capitalist firms to bypass financial capitalist firms and access funds directly from savers. Add to these ambiguities all of the other overdeterminants that were exerting diverse impacts on the subsumed class payment required to secure money capital, and no ready assertion can be made as to the relationship between the dénouement of New Deal financial reforms and this subsumed class payment.

Given that any policy initiative implies its own negation, and given the multitude of overdeterminants that are set in motion by the contradictory impacts of the policy intervention, the possibility of establishing a causal determination between policy intervention and outcome is abandoned. Thus we forsake at the outset any attempt to conclude that a policy "works" (or doesn't "work") to achieve its desired objective. This represents a dramatic departure from the more conventional motivations for studying policy. The economic history presented in this dissertation remains agnostic about the matters typically advanced in economic history (namely offering conclusions about the success of an intervention and offering suggestions as to how an intervention might be improved). Instead, this dissertation follows the unfolding of the contradictions of a particular set of reforms to illustrate the uncontrollability of policy from an overdeterminist perspective. 


\section{CHAPTER 7}

THE TRANSFORMATION OF COMMERCIAL BANKS DURING THE DECLINE OF NEW DEAL FINANCIAL COMPARTMENTALIZATION

\section{Commercial Bank Response To The Competitive Threats During The Erosion Of Financial Compartmentalization}

Chapter six argued that, despite the intention of New Deal financial reforms to enhance commercial bank profitability as a condition of existence for the stability of the commercial banking system, these reforms ultimately had the unintended consequence of provoking competitive struggles that undermined commercial bank profitability. As the supports to commercial bank profitability contained in New Deal financial compartmentalization were subverted by competition from non-bank financial capitalist firms, commercial banks lost ground both in their ability to attract savings and in the provision of funds in the second moment of financial intermediation. These developments culminated in a profitability crisis for commercial banks. While in 1970 the ROA of FDIC member commercial banks stood at .85\%, it decline thereafter until by 1985 it stood at $.66 \%$ and hit its low point in 1987 at $.09 \%$. (see Figure 21, chapter 5)

Commercial banks responded in several ways to the recognition that the New Deal regulatory framework was increasingly impairing their profitability. While chapter 6 discussed some of these responses as they related to the creation of diversified firms via the holding company structure, this chapter focuses on the practices adopted within 
commercial banking firms ${ }^{1}$ to enhance their profitability. This chapter outlines two broad categories of competitive strategies employed by commercial banks to manipulate the confines of New Deal financial compartmentalization to their advantage. First, commercial banks attempted to enhance their profitability by innovations within the practice of commercial banking. These sorts of competitive responses will be referred to as "commercial banking strategies", since they fall within the confines of the definition of commercial banking employed in this dissertation, namely that commercial banking constitutes the taking of deposits and financing loans based on these deposits. These commercial banking strategies focussed both on commercial bank activities in both the first and second moments of financial intermediation. Secondly, commercial banks sought to enhance their profitability by engaging in activities that expanded beyond the class analytic definition of commercial banking. Commercial banks began seeking money in the first moment of financial intermediation through sources other than deposits, and they began to engage in forms of value expansion other than the earning of subsumed class and non-class revenue from the provision of loans. These sorts of competitive responses will be referred to as "strategies beyond traditional commercial banking", despite the fact that these strategies were employed in firms that, for regulatory purposes, were categorized as commercial banks.

\footnotetext{
${ }^{1}$ By referring to the practices adopted "within commercial banking firm", we mean activities within the entity classified as a commercial bank. If that entity existed within a holding company structure that had subsidiaries that engaged in non-commercial banking activities, we are not referring to the plethora of activities occurring in the non-commercial bank subdivisions of the holding company.
} 
Whether within or outside of traditional commercial banking, these strategies employed to enhance commercial bank profitability exhibited some commonalties. As many of the benefits of New Deal compartmentalization were transformed into competitive liabilities for commercial banks, commercial bank profitability was constrained by both interest rate controls and the regulatory constraints that prohibited commercial banks from engaging in non-banking forms of value expansion. Moreover, as commercial banks lost their hegemonic status among financial intermediaries, the necessity of maintaining required reserves was regarded as an increasingly burdensome competitive liability. The evasion of these major regulatory constraints became a central focus of commercial bank strategies to respond to the threats to their profitability posed by non-bank financial capitalist firms.

However, commercial banks also formulated their competitive strategies with an eye to maximizing their regulatory advantages. Their privileged access to the payments system was increasingly eroded but not eliminated as a competitive advantage vis à vis non-bank financial capitalist firms. However commercial banks' most distinctive advantage was their ability to offer government sponsored deposit insurance and their explicit access to lender of last resort support. The existence of this safety net helped to induce commercial banks to respond to their profitability problems by moving into activities that implied greater risk exposure for the commercial banking system. Thus while New Deal financial reforms had sought to support the stability of the commercial 
banking system, over time one of their unintended consequences was to induce commercial banks to engage in activities that compromised the stability of the commercial banking system.

\section{Commercial Banking Strategies In The First Moment Of Financial Intermediation}

In order to respond to the incursions of non-bank financial capitalists on their traditional terrain, commercial banks sought ways of buttressing their access to savings in the first moment of financial intermediation. Since New Deal interest rate controls hindered the ability of commercial banks to attract savings in an environment of accelerating inflation, commercial banks were obliged to subvert the interest rate controls that had originally been enacted to support their profitability. Depending on the type of deposit account in question, raising the interest paid to attract deposits involved overcoming the Regulation Q cap on the rate of interest that could be paid on savings accounts, or overcoming the complete prohibition on paying interest on transactions deposits. However, if a commercial bank successfully managed to evade these restrictions to increase their access to savings, this implied putting upward pressure on the $\mathrm{Y}$ expenses associated with attracting deposits. Figure 29 illustrates how interest paid on domestic deposits as a percentage of total domestic deposits grew dramatically during the 1970 s and 1980 as commercial banks were compelled to pay more to attract deposits. Thus the success of commercial banks' evasion of interest rate controls had contradictory effects in that it both enhanced and detracted from commercial bank profitability. 
Figure 29: Interest On Deposits In Domestic Offices As A Percentage Of Total Domestic Deposits Of FDIC Member Banks Source: Historical Statistics on Banking CB06 and CB15.

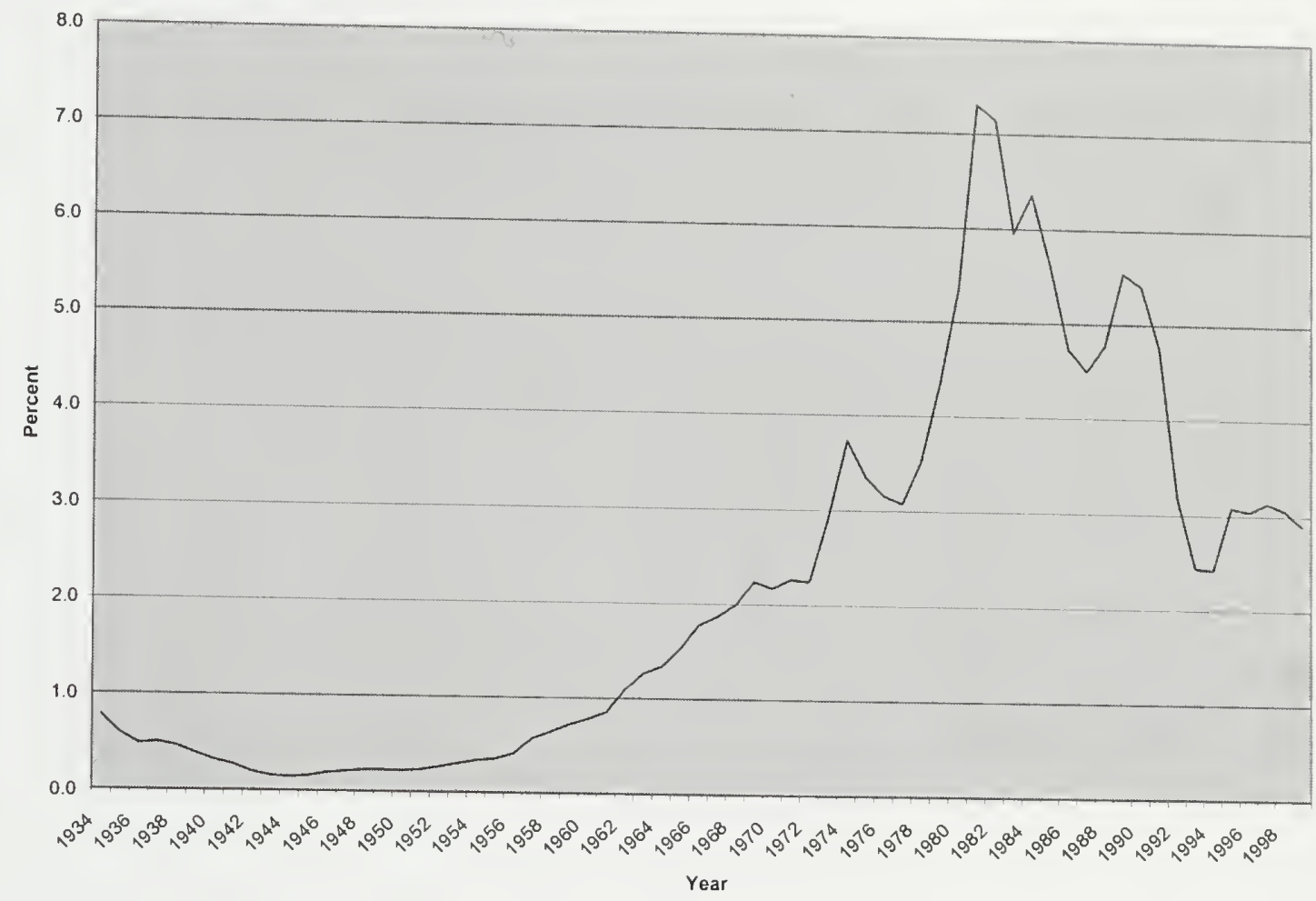

To deal with this dilemma, commercial banks sought to devise competitive strategies that simultaneously promoted their access to savings while defraying the upward pressure on their expenses of attracting these savings. One response to this dilemma was the attempts by commercial banks to enhance the earning potential of deposits. This so-called "liability management" sought to enable a given amount of deposits (the liabilities of the commercial bank) to support more lending, thus compensating for the increased costs of attracting funds from savers. One of the ways to support the earning potential of deposits is to manage required reserve positions more aggressively. Required reserves represent a forgone opportunity to make new loans and they do not earn interest at the Federal Reserve. To the extent that commercial banks 
could reduce their holdings of reserves for a given amount of deposits, this freed funds to generate new lending. However, as reserves decline relative to deposits, commercial banks become more highly leveraged and thus more vulnerable to instability. Thus to the extent that commercial banks attempted to enhance their profitability by diminishing their holdings of required reserves per dollar of deposits, this development promotes commercial bank profitability by creating greater fragility in the commercial banking system.

Perhaps the most famous example of liability management was the development of the federal funds market. As was discussed in chapter 3 , lending conditions may be such that a commercial bank may elect to hold excess reserves. Commercial banks developed the federal funds market to take advantage of any slack in the required reserves of the commercial banking system as a whole. The federal funds market is open almost exclusively to commercial banks, and it allows a commercial bank with excess reserves to "lend" them overnight to a commercial bank that has insufficient reserves to support its lending opportunities. By improving the capacity of the commercial banking system to fully employ any excess reserves, the development of the federal funds market enhanced the profitability of the "borrowing" commercial banks (which could now advance new loans) and "lending" commercial banks (that earns income for their provision of excess reserves). When federal funds transactions by commercial banks first appeared in the

\footnotetext{
${ }^{2}$ Prior to 1963 the federal funds market was constrained, since regulation forbade banks from making loans to one borrower of more than ten percent of a bank's capital. In 1963 the Comptroller of the Currency deemed these transactions to be agreements to repurchase rather than loans. This freed banks with excess reserves from the regulatory limits on lending to one borrower, which greatly stimulated the development of the federal funds market. (Mayer, 2001, 171)
} 
FDIC's statistics in 1965, federal funds purchases on the books of FDIC-insured commercial banks amounted to only about $\$ 2.4$ billion. By 1980 , commercial banks had in excess of $\$ 133$ billion in federal funds on their books, and by 1990 this figure reached \$245 billion. (

However, the development of the federal funds market also had its perils. Federal funds transactions are unsecured and are not protected by deposit insurance. In addition, they are typically very short term (one day or weekend). In this context, commercial banks rumored to be in distress may find themselves suddenly unable to roll over their federal funds borrowings. As will be discussed below, problems rolling over federal funds borrowing helped to provoke the failure of the Franklin National Bank (1974) and the Continental Illinois Bank (1984). Thus commercial banks experiencing a profitability crisis face a quandary. Borrowing heavily in the federal funds market allows a bank to increase its loan portfolio and thereby earn its way out of difficulties, however a bank employing this strategy is increasingly exposed to the possibility of a liquidity crisis reminiscent of a depositor-induced bank run.

Another dimension of the competitive strategies of commercial banks in the first moment of financial intermediation was to find ways of evading the prohibition on the payment of interest on checking accounts. One such example of the financial innovations designed to do this is the "sweep" account. Larger depositors often require extensive checking privileges, particularly capitalist firms keeping large sums in checkable deposits for payroll purposes or other "bulges" in their expenses. These deposits had been an 
attractive source of interest-free funds for commercial banks, yet they were threatened to the extent that non-bank financial capitalists could mimic the checking privileges of bank deposits. To prevent the loss of these deposits, commercial banks developed sweep accounts to enable large depositors to earn a rate of return on their checking accounts. Sweep accounts move funds in excess of some prearranged limit out of the depositor's checking account and into an overnight repurchase agreement ${ }^{3}$ that would allow the depositor to earn a return on these excess funds. In 1980, commercial banks won the ability to extend these sorts of accounts to smaller depositors in the form of "automatic transfer savings" accounts that transferred funds from checking to interest-bearing savings accounts.

Commercial banks also sought ways around the Regulation Q cap on the interest payable on savings accounts. The development of certificate of deposit (CD) exemplifies this strategy. A CD provides a saver with interest payments and the return of the principal at maturity in a manner analogous to a bond. However, CDs are classified as time deposits ${ }^{4}$, and are thus covered by deposit insurance. In the early 1970 s, commercial banks successfully lobbied for CDs to be freed from Regulation Q limits altogether. Thanks to these developments, the CD market grew ten-fold between 1965 and 1975 . (Meerschwam 1987, 79) However, CDs also add new sources of instability to commercial banks. CDs are marketed widely (thus evading the prohibition on interstate

\footnotetext{
${ }^{3}$ In such a repurchase agreement, the bank would sell its customer a Treasury bill overnight, and repurchase the Treasury bill the following day. The repurchase would be at a given rate, equivalent roughly to the interest earned on the Treasury bill in the intervening period.

${ }^{4}$ Retail CDs are classified as small time deposits, in contrast to large negotiable CDs (wholesale CDs) that are classified as large time deposits (see below).
} 
banking to some degree) and therefore enable commercial banks to access funds from savers who have no longstanding relationship with the bank. While CDs enable commercial banks to access additional funds quickly by making small changes in the offering rate, they also contain the potential of losing funds quickly. ${ }^{5}$

While the federal funds market enabled commercial banks to manage their required reserve more effectively, and such innovations as sweep accounts allowed commercial banks to evade New Deal interest rate controls, commercial banks sought financial innovations that incorporated both the minimization of required reserves and the evasion of interest rate controls. One of the ways of doing this was to manipulate the regulatory categories under which deposits are classified. To the extent that a deposit could be reclassified as a "savings" account rather than a "checking" account, the reserves held against that account could be reduced. Moreover, while checking accounts paid no interest, savings accounts could pay up to the Regulation Q ceiling. If a deposit could be classified as a savings account, yet be made to function like a checking account, the commercial bank would both economize on required reserves and evade the prohibition on paying interest on checking accounts. This savings emanating from lowering required reserves positions would to some extent counter-act the upward pressure on $\mathrm{Y}$ expenses associated with paying interest on the deposits that were previously interest-free. This strategy was exemplified by the introduction of Negotiable

\footnotetext{
${ }^{5}$ The potential instability introduced by commercial bank participation in CD markets attracted concern in 1965 when several weakened commercial banks offered brokers of CDs bonuses to place their issues and subsequently failed. (See Myers 1971, 384)
} 
Order of Withdrawal (NOW) accounts, which enabled commercial banks to offer "negotiable orders of withdrawal" that function like checks on accounts that are not categorized as transactions accounts.

Despite the variety of financial innovations employed to economize on required reserves, pay interest on accounts that functioned like checking accounts, and evade the Regulation Q cap on savings accounts, commercial banks were still under great pressure in the late 1970s. In response to this situation, commercial banks were increasingly withdrawing from Federal Reserve membership because the Federal Reserve imposed more stringent required reserves ratios than many state-chartered, non-member commercial banks were required to maintain. ${ }^{6}$ This declining Federal Reserve membership created concerns among Federal Reserve officials about their capacity to implement monetary policy. The Depository Institutions Deregulation and Monetary Control Act (DIDMCA) of 1980 dealt with this by establishing uniform reserve requirement for all depository institutions, regardless if they were members of Federal Reserve. ${ }^{7}$ This eliminated the incentive for commercial banks to flee their Federal Reserve membership, however commercial banks were able to extract several concessions in the Act. The DIDMCA lowered required reserves to $12 \%$ on transactions

\footnotetext{
${ }^{6}$ Nationally chartered commercial banks are required to be members of the Federal Reserve, while state chartered commercial banks can chose whether or not to belong to the Federal Reserve.

${ }^{7}$ The DIDMCA gave all banks access to discount window, check clearing, safekeeping of securities wire transfers, automatic clearing facilitates and cash transportation services. These were once free, but now are offered at cost to all depository institution that maintain their required reserves. (Gart 1994, 83)
} 
accounts and 3\% on non-transactions accounts. ${ }^{8}$ After further lobbying by commercial banks, by 1990 required reserves were eliminated on non-transactions accounts, and by 1992 the checking account required reserves ratio was reduced to $10 \%$. The DIDMCA also phased out Regulation Q over a period of 6 years, and overrode state usury ceilings on mortgage, agricultural, business and consumer loans in excess of $\$ 25,000^{\circ}$, and increased FDIC insurance to cover $\$ 100,000$ per deposit account. Both the financial innovations created by commercial banks to enhance their profitability in the first moment of financial intermediation, and the legislative changes to required reserves ratios, ultimately had a substantial impact on the reserves held in the commercial banking system. As Figure 30, indicates required reserve holdings of the commercial banking system were dramatically reduced as a proportion of the total financial assets held by commercial banks.

\footnotetext{
${ }^{8}$ As of 1951 required reserves were $6 \%$ on savings accounts, and as high as $23 \%$ on demand deposits (depending on the classification of the bank). These required reserve ratios were eroded throughout the post-war period prior to the passage of the DIDMCA. (See Feinman undated, 587-588)

${ }^{9}$ States could re-impose usury laws by 1983 if they so chose.
} 
Figure 30: Vault Cash And Reserves Held At Federal Reserve As A Percentage Of The Total Financial Assets Of Us-Chartered Commercial Banks

Source: Flow of Funds, L. 110.

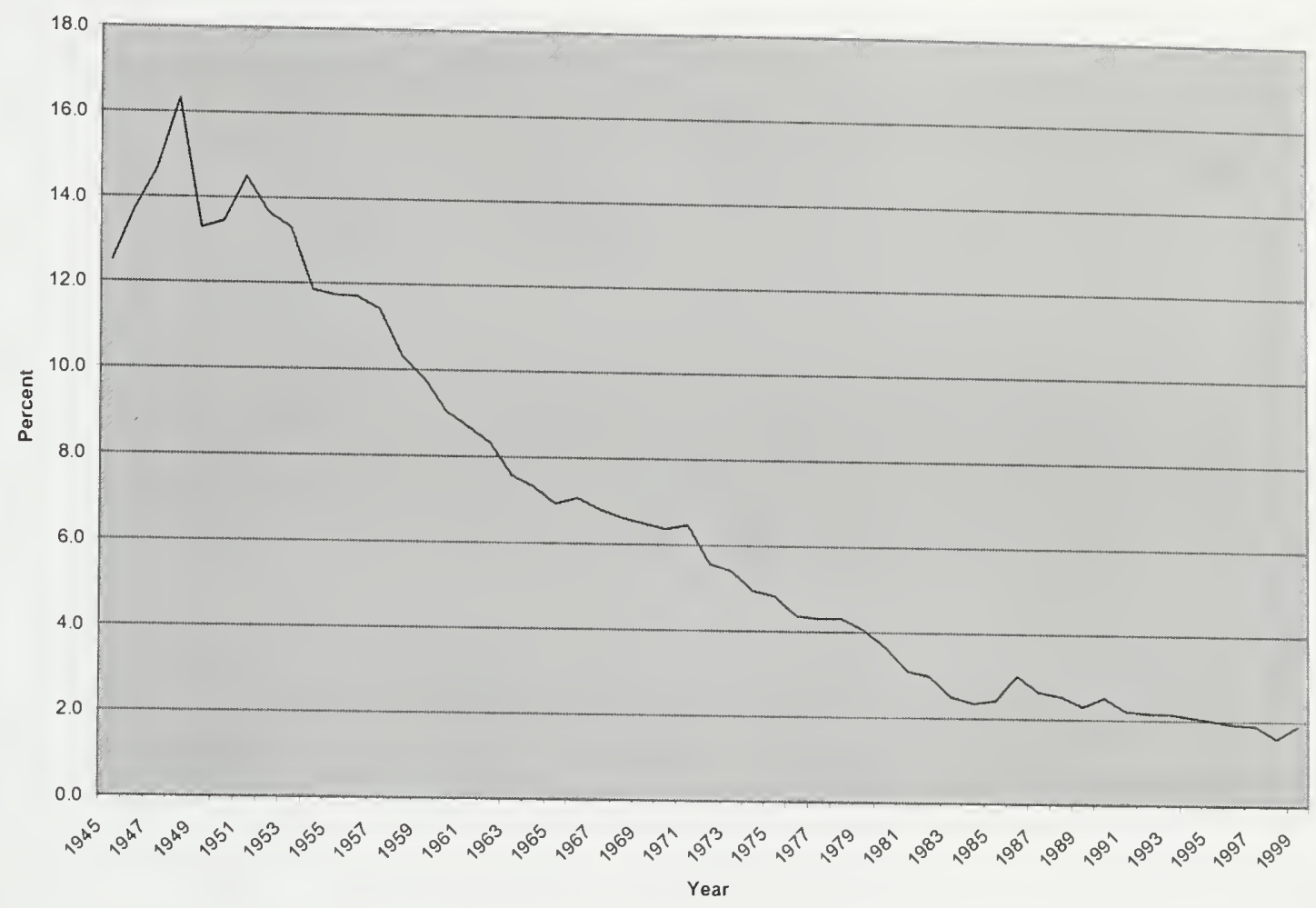

While the reserves held in the commercial banking system were diminishing, commercial banks were succeeding in increasing the sorts of activities that were eligible for deposit insurance. Thus the governmental safety net was widening while at the same time the capacity of stabilizing attributes of required reserves were being compromised. For example, while Regulation Q was undergoing its six year phase-out period, commercial banks faced a quandary when interest rates soared during the early part of Volker's tenure as Chairman of the Federal Reserve. Regulation Q was a dire competitive liability, particularly since MMMFs that could offer money market rates of return were producing a hemorrhage of funds from savings deposits. To deal with this problem, the 
1982 Depository Institutions Act (the "Garn-St .Germain" Act) authorized commercial banks to offer money market demand accounts (MMDA). These accounts invested in money market instruments just as MMMFs did, however they were covered by deposits insurance, unlike MMMFs. In addition, MMDAs were classified as savings accounts because of a regulatory compromise allowing only a fixed number of "checks" written on the account per month, which helped to economize on the required reserves held to support them.

The strategy of taking fuller advantage of commercial banks access to the government safety net was epitomized by development of so-called "brokered deposits". A broker, typically an investment bank ${ }^{10}$, could split an amount of funds in excess of the deposit insurance cap among many commercial banks so that each bank held only the maximum amount that is covered by FDIC. In this way, the depositor enjoyed deposit insurance on their entire amount despite the explicit cap on deposit insurance for a single depository account. If the funds were then put in a MMDA, the depositor could earn a money market rate of return. As brokered deposits grew in popularity, the FDIC became concerned that the heavy use of brokered deposits were promoting dubious banking practices. Commercial banks in difficulties might be tempted to pay a premium to have access to brokered deposits, and the insurance coverage on such deposits diluted the incentive for the broker to avoid dealing with commercial banks of questionable solvency. By the early 1980s the heavy use of brokered deposits were figuring

\footnotetext{
${ }^{10}$ This financial innovation adds a third party, an investment bank, into the financial intermediation process. Thus investment banks were able to derive fee income from facilitating the matching of depositors and commercial banks, which marks a shift in the subsumed class struggle between commercial and investment banks.
} 
prominently in bank failures, and in some cases brokered deposits were in excess of 50\% of total liabilities of the failed bank. ${ }^{11}$ While the FDIC attempted to ban this practice in 1984 (by instituting an insurance limit of $\$ 100,000$ per broker), this was defeated in court. After a protracted struggle, limits on brokered deposits were included in the Financial institutions Reform, Recovery and Enforcement act of 1989 (FIRREA) and the Federal Deposit Insurance Corporation Improvement Act (FDICIA) of 1991.

\section{Commercial Banking Strategies In The Second Moment Of Financial Intermediation}

In addition to the attempts to enhance their deposit base in the first moment of financial intermediation, commercial banks also endeavored to support their profitability by adapting their competitive strategies in the second moment of financial intermediation. The financial innovations described in chapter 6 were debilitating to commercial banks, in that large corporate borrowers with good credit ratings were increasingly accessing funds from securities issuance, the commercial paper market and other sources rather than from commercial banks. To replace these borrowers, commercial banks increasingly lent to riskier borrowers. This also enhanced the earning power of their loan portfolios since the interest rate charged on a loan increases according to the perceived riskiness of the loan. This movement into risky lending areas was particularly pronounced among the largest commercial banks. A bank is in better situated to withstand default risks in its loan portfolio if it is confident of receiving the fullest possible benefits of the government

\footnotetext{
${ }^{11}$ This data is taken from a report by the Federal Reserve Bank of New York quoted in d'Arista, 137.
} 
safety net. Thus the largest banks which are perceived as "too-big-to-fail" were best able to engage in riskier lending, since they benefited most from the moral hazard dilemma implicit in the government safety net.

The increasing emphasis on credit cards in the 1970s and beyond exemplifies this new trend in commercial bank lending. Technological developments (especially the establishment of standards for magnetic strips in 1970) reduced the record-keeping expense of these small consumer loans and enabled them to be standardized in credit card format. Credit card lending is viewed as risky, given that credit card loans are unsecured debt. However, credit cards have generally been able to evade usury limits to charge high rates of interest. Hubbard cites an named Federal Reserve source indicating that the rate of return from credit card lending is higher than that of any other asset - a premium of $12 \%$ above the interest rate applied to short-term default risk-free lending. (Hubbard 1996, 325) A final advantage of credit card lending is also that they can generate fee income (see below), in the form of non-class revenue from the fees paid by stores that accept the credit card, and often fees paid by the credit card holder. Thanks to these advantages, credit card loans (and related loans) exhibited a compound annual growth rate of $15 \%$ between 1970 and 1999, with many years in the 1970s and mid 1980s exhibiting an annual growth rate in credit cards and other related loans in excess of $25 \%$. (author's calculations from HSOB CB13 and CB15) In the difficult times in the 1980s and early 1990s, credit cards proved to be a salvation for commercial banks. Mayer quotes a MasterCard official's claim that "In 1992 Citibank was technically insolvent. What kept them going was a billion-dollar profit on credit cards". $(1997,191)$ 
In addition to expanding into consumer lending, commercial banks expanded their lending to third world states in the $1970 \mathrm{~s}^{12}$. As large US commercial banks lent aggressively to the third world governments (a practice that came to be know as "loanpushing"), these states experienced an alarming increase in the level of indebtedness. ${ }^{13}$ By the end of 1982, the nine major US commercial banks had advanced LDC debtor countries loans that constituted 288\% of their bank capital. (Sachs and Huizinga 1987, $558)^{14}$ US commercial banks were plunged into crisis when, in the face of the high interest rates in the early 1980s, it became apparent that Mexico (and other debtor countries) could not meet its debt service commitments in 1982. For the next five years commercial banks were able to manage this crisis, thanks in part to regulatory permissiveness that allowed the banks to count as current income the interest payments they received as a result of "involuntary" loans (that is, new loans made to the debtor in order cover interest obligations and thereby prevent outright default. (see Sachs and Huizinga 1987, 557) By some accounts, this regulatory forbearance was necessary lest seven or eight of the ten largest US banks fall into official insolvency. (FDIC 1997, 207)

\footnotetext{
${ }^{12}$ The banks were assisted in their zeal to lend to third world countries by a ruling of the OCC in 1979. A nationally chartered commercial bank is generally subject to a $10 \%$ limit to loan to any one entity. The OCC determined in 1979 that the various public sector borrowers in an LDC did not have to be considered as a single entity, thus many commercial banks that would otherwise have been in violation of the $10 \%$ rule were able to continue to engage in highly concentrated lending. A Senate report at this time observed that "a single U.S. bank may have loans outstanding to 20 different public entities in Brazil, none of which individually exceeds 10 percent of the bank's capital, but which taken together may far exceed the limit, and still not be in violation of the rule" (in FDIC 1997, 204).

${ }^{13}$ In 1970 the 15 most heavily indebted nations had external public debt of about $\$ 18$ billion, or almost $10 \%$ of their GNP. By 1987 these states owed $\$ 402$ billion, or about $47.5 \%$ of their GDP (see Ferraro and Rosser 1994, 333).

${ }^{14}$ US commercial banks other than these nine major banks were much less exposed to third world debt, since their loans consisted of $116 \%$ of bank capital by the end of 198. (Sachs and Huizinga. 1987, 558)
} 
By this mechanism, Sachs and Huizinga report that "[i]ronically, during the 1982-86 the debt crisis did not have a serious adverse effect on the reported current earnings of the banks, even though it called into question their very solvency". (1987, 567, italics in original) This gave US commercial banks some time to respond to the problem, so that by the end of 1986 their exposure to LDC debtors was $154 \%$ of capital. (ibid., 558) By 1987, the situation could be publicly acknowledged, as was symbolized when Citicorp announced that it would increase in its loan loss reserve by $\$ 3$ billion to address its third world debt exposure. As a result of losses connected to the third world debt problem, large commercial banks posted losses of about \$10 billion in the second quarter of 1987. (ibid., 570)

In the attempt to earn their way out of both their specific third world debt difficulties and their general profitability problems, commercial banks turned to other forms of risky lending. In the 1980s commercial banks increased their lending to activities connected with commercial real estate, mergers and acquisitions, and oil and gas sectors, all of which are traditionally perceived as risky lending areas. This was facilitated, in part, by legal changes such as The Economic Recovery Tax Act of 1981 that accelerated depreciation allowances ${ }^{15}$, which made real estate investment more attractive, and included other provisions that facilitated the use of debt to finance corporate takeovers and leveraged buyouts. (Wolfson 1994, 109-112) Real estate loans, for example, constituted $17.8 \%$ of total commercial bank assets in 1980 , however by 1990 this had climbed to about 27.1\%. (FDIC 1997, 152) However these real estate loans

\footnotetext{
${ }^{15}$ Many of these provisions were subsequently repealed by the Tax Reform Act of 1986, which contributed to the collapse of the commercial real estate market in the later 1980s.
} 
had increasingly been advanced on the strength of the underlying collateral rather than on the borrowers ability to generate earnings from the asset. ${ }^{16} \mathrm{~A}$ collapse in commercial real estate, particularly in New England, had disastrous implications for commercial banks, and played a prominent role in commercial bank failures in the later 1980s and early 1990s.

As commercial banks experienced problems in the riskier lending activities undertaken to buttress their profitability dilemma, the commercial banking system as a whole grew more precarious. In 1986, nine US banks enjoyed a long-term triple A rating from Moody's, but by 1993 J.P. Morgan and Co. was the only bank left in this category. (Mayer 2001, 220) The impact of non-performing loans aggravated the pressure that commercial bank profitability was already experiencing, and contributed to an accelerated incidence of bank failures. Before 1975, fewer that 10 FDIC-member banks failed per year. Bank failures exceeded 120 per year between 1985 and 1992, and in some years reached 200 or more per year. (see Figure 17, Chapter 5)

\footnotetext{
${ }^{16}$ An account of the erosion in loan underwriting standards during the commercial real estate boom in the 1980s is given in FDIC's History of the Eighties- Lessons for the Future: An Examination of the Banking Crises of the 1980s and Early 1990s. (1997) Overall returns on commercial real estate properties fell form $18.1 \%$ in 1980 to a negative $6.1 \%$, and remained negative or close to zero until 1994 (150).
} 


\section{Responses Beyond Traditional Commercial Banking: Competitive Strategies In The First Moment Of Financial Intermediation}

Given the pressure experienced by commercial banks during the dénouement of financial compartmentalization, commercial banks increasingly engaged in activities that fall outside of commercial banking as we have defined it in the dissertation. Chapter 3 defined commercial banking as the taking of deposits and using those deposits to make loans. Thus commercial bank non-class revenues in the first moment of financial intermediation consist exclusively of the receipt of deposits, while value expansion in the second moment of financial intermediation consists of the subsumed class and non-class revenues derived from interest income on commercial bank loans. As commercial banks fashioned competitive strategies that moved beyond traditional commercial banking, their mix of revenues and expenditures changed. In the first moment of financial intermediation, commercial banks increasingly accessed funds via means other than deposits. In the second moment of financial intermediation, commercial banks generated value inflows through means other than earning interest income on loans. ${ }^{17}$ The current section will discuss the migration of commercial banks into activities outside of traditional commercial banking in the first moment of financial intermediation, while the following section will consider the efforts of commercial banks to expand value by means other than earning interest income from loans.

\footnotetext{
${ }^{17}$ For the purposes of this discussion, we leave aside the traditional activities that are incidental to commercial banking, for example the provision of safety deposit boxes, that generate revenues that are not interest income.
} 
In banking parlance, accessing savings in the first moment of financial intermediation in forms other than traditional deposits is called "purchasing" funds. ${ }^{18}$ Purchased funds are a non-class revenue that requires the bank to incur a $Y$ expense, similar to the $Y$ expense paid to attract deposits. Purchased funds are not subject to New Deal interest rate controls or reserve requirements, nor are they eligible for deposit insurance. One of the landmarks in the use of purchased funds by commercial banks was Citibank's development of the large negotiable certificate of deposit (CD) in $1961 .{ }^{19}$ The large negotiable $\mathrm{CD}$ has a relatively short maturity (typically 30 to 90 days), but the creation of a secondary market for $\mathrm{CDs}$ enabled the owner to access funds prior to maturity. These "wholesale" CDs are usually denominated in amounts of $\$ 1$ million or more, and are often purchased by institutional investors seeking a small premium over Treasury bills. Other ways of accessing purchased funds include Repurchase Agreements (RPs) ${ }^{20}$, commercial paper issued by a commercial bank via its holding company $y^{21}$, or via borrowing in the Euromarket. Ironically, these instruments often enabled commercial

\footnotetext{
${ }^{18}$ Purchased funds are also known as managed liabilities.

${ }^{19}$ In the early post-war era, commercial banks held large amounts of government securities that they had accumulated during the war effort. This provided commercial banks with a buffer, in that should they require fund in excess of their deposit base, they could turn to the portfolio of government securities. However, by the 1960 s commercial bank holdings of these securities had been depleted substantially, thus commercial banks turned increasingly to purchased funds. (Mayer et. al. 1984, 66)

${ }^{20} \mathrm{An}$ RP is an agreement to sell and subsequently repurchase securities. A commercial bank in need of funds will sell securities for some specified time period, with the agreement that it will repurchase them at a later date.

${ }^{21}$ Thanks to a 1962 ruling from the Comptroller of the Currency, commercial banks were permitted to issue commercial paper. However, a struggle ensued when the Federal Reserve ruled that commercial paper constituted a time deposit in 1966 . Ultimately this was resolved as commercial paper came to be issued by a bank holding company (or a non-bank subsidiary), and the funds were made available to the affiliated commercial bank when the issuer of the commercial paper purchased the banks loans. (Wolfson 1994, 1789)
} 
banks to again access some of the funds that non-bank competitors had lured away from the commercial banking system, as when a MMMF or a pension funds purchases a large negotiable $\mathrm{CD}$ or commercial paper from a commercial bank.

Despite their advantages as another source of funds with which to earn income, purchased funds are sometimes referred to as the "hot money" of bank funding (Sinkey $2002,105)$ since they can dramatically exacerbate commercial bank instability. Participants in the purchased funds markets tend to be very large, well-informed institutions that react quickly to any adverse information (as well as rumor ${ }^{22}$ ) about the wellbeing of a bank. Over a very short period of time, a commercial bank can find itself virtually shut out of purchased funds markets, regardless of the return that it offers on its CDs and other instruments with which it purchases funds. Moreover, participants in purchased funds markets can reallocate their funds almost instantaneously through electronic channels in a "purchased funds run" or "electronic bank run". While a traditional bank run might be attenuated by the dramatic arrival of money in an armored truck to placate depositors, purchased money runs allow much less time for banking regulators to respond before a bank becomes insolvent. To reflect the potential instability of this source of funds for commercial banks, the FDIC defined many of these purchased funds as "volatile liabilities". ${ }^{23}$ This descriptive regulatory designation has more recently been changed to the more benign-sounding "non-core liabilities".

\footnotetext{
${ }^{22}$ Rumors concerning the possibility that a Japanese bank would acquire Continental Illinois, or that the OCC had approached other banks to assist Continental, helped to produced the electronic bank run that devastated that bank in May 1984.

${ }^{23}$ As defined by FDIC, volatile liabilities include large denomination time deposits (such as CDs), foreign office deposits, federal funds purchased, and repurchase agreements and other borrowings. (Sinkey 2002, 435)
} 
As commercial banks came to rely more heavily upon them, purchased funds were increasingly implicated in bank failures. The failure of Franklin National Bank in 1974 married both the tendency to extend loans to poor credit risks, alongside a heavy dependence on purchased funds. (Wolfson 1994, 56) Once Franklin's problems became known, a purchased fund run hurtled Franklin towards outright failure very rapidly. Although Franklin was not a particularly prominent bank, the Federal Reserve judged the situation to be so potentially damaging to both the domestic market for bank CDs and the Eurodollar market that it Franklin could not be permitted to fail. To resolve the situation at Franklin, the FDIC required time to arrange for other banks to assume the Franklin's liabilities and purchase its assets. This implied that the Federal Reserve was obliged to keep Franklin operating on life support for several months while the situation was resolved. Franklin was kept open with borrowing from the discount window that averaged slightly more than $\$ 1$ billion per day between May 8 and October 7 (Sinkey $2002,563)$, and Federal Reserve guarantees on a daily average of $\$ 300$ million in loans from other banks on the federal funds markets. (see Wolfson 1994, 56-59)

While lender of last resort support was conceived of as a support to the depositary system, the increasing reliance of commercial banks on purchased funds has generated the de facto understanding that the Federal Reserve stands ready to stabilize commercial banks in their undertakings related to purchased funds. To the extent that the Federal Reserve may be called upon to address a crisis that emanates from commercial banks' involvement with purchased funds, this represents an expansion of this lender of last resort mandate. Any financial capitalist firm may purchase funds in the first moment of 
financial intermediation. Indeed many of the instruments that commercial banks use to purchase funds, such as commercial paper, are also used by non-bank financial capitalists. Thus providing a government-backed safety net for commercial bank dealings in purchased funds represents a movement towards the provision of emergency assistance to financial capitalist activities in general - so long as a given crisis can be shown to destabilize the commercial banking system. In this way, the migration of commercial banks into purchased funds, and the increasing obligation that the government safety net address banking crisis that have large purchased funds components, represents another intensification of the moral hazard dilemma faced by the government.

This implied lender of last resort support assists commercial banks in the market for purchased funds since it lowers the $\mathrm{Y}$ cost of attracting purchased funds vis à vis their non-bank financial capitalist competitors. To the extent that lender of last resort support assists commercial banks in attracting purchased funds, commercial banks have a competitive advantages vis à vis the non-bank financial capitalist firms in purchased funds markets. Moreover, the advantage conferred by this implicit governmental support is greater the larger the commercial bank, since the "too big to fail" precept implies that larger banks are more likely to receive this support than are smaller banks. Thus the larger banks are more active in securing purchased funds than are the smaller banks. Sinkey notes that in 1985 , purchased funds constituted $35 \%$ of the average consolidated assets of all FDIC-insured commercial banks, while the ten largest commercial banks held purchased funds equivalent to almost $60 \%$ of their average consolidated assets. 
$(2002,106)^{24}$ Implicitly the importance of lender of last resort support is reflected in the pricing dynamics of purchased funds markets. Wolfson cites research illustrating that, during an instance of instability in the wholesale CD market, a "two-tiering" effect took place in which banks regarded as too big to fail paid less on their CDs than did smaller banks, regardless of the profitability indicators of the bank in question. (Wolfson 1994, 57)

Another implication of the de facto extension of emergency government assistance to address the purchased fund activities of commercial banks is the increased expense to the government of resolving bank failures. Deposit insurance was designed to contain banking runs by insuring individual deposits, so an upper cap (currently of $\$ 100,000)$ was seen as sufficient to prevent legions of small depositors from withdrawing their funds. However, to address a purchased fund run, creditors must be assured that their funds are protected in their entirety. This dilemma was illustrated by the failure of Continental Illinois (ranked as the seventh largest bank at the time of its collapse). Continental was a heavy user of purchased funds ${ }^{25}$, to fund its adventures lending strategies in energy, real estate and other notoriously risky undertakings. But Continental was by no means unusual among large US commercial banks, as Charles Partee, chair of the Federal Reserve Board of Governors committee on bank supervision, confirmed:

\footnotetext{
${ }^{24}$ While the largest commercial banks have diminished their reliance on purchased funds somewhat in the 1990s, (purchased funds constituted $45 \%$ of the average consolidated assets of the ten largest FDIC-insured commercial bank in 1999), medium and small commercial banks held only $26 \%$ (nedium sized banks) and $16 \%$ (small sized banks) of their average consolidated assets as purchased funds.

${ }^{25}$ In part due to the unit banking laws in Illinois which limit the accessibility of deposits, Continental funded its growth in the late 1970s via the purchased funds markets. In 1981 "core deposits" (i.e. traditional deposits) made up just $20 \%$ of the bank's total deposits (which include Negotiable CDs and Foreign deposits from Euromarkets). (FDIC, 1997, 242 and 255)
} 
With Continental Illinois, when you get right down to it, here was a $\$ 40$ billion bank with only $\$ 4$ billion in deposits. The core of the bank was very, very small. They're selling CDs, getting money from the Eurodollar market, selling commercial paper from the bank holding company. It was an extreme case- but it wasn't all that unusual. Citibank has a small core too. Lots of big banks do. (in Grieder 1987, 525-6)

Largely in response to the Continental collapse, the term "too-big-to-fail" gained popularity in the banking lexicon. Given the possibility that the insolvency of a large bank might disrupt the markets for purchased funds and potentially ramify to other large banks, the FDIC was forced to guarantee that all depositors and other general creditors of Continental would be "fully protected", regardless of the cap on deposit insurance, despite the fact that a number of the liabilities in question were not insurable deposits. (FDIC 1997. 244)

From the point of view of the class analysis of financial capitalist firms developed in this dissertation, a firm with only a minor emphasis on deposits would be more accurately characterized a diversified financial capitalist firm. Chapter 6 described the attempts by commercial banks to diversify their financial capitalist activity via the holding company structure in which other subsidiaries engaged in non-banking financial capitalist activity. However, the movement into purchased funds represents another aspect of this diversification. Without changing the legal entity in which the commercial bank was housed, commercial banking firms managed to diversify their financial capitalist activities within the firm that continued to be classified as a commercial bank. Of course, the monumental advantage to housing non-banking financial capitalist activity within a firm categorized as a commercial bank was that it provided a way to extend 
government safety nets to more types of financial capitalist activity. Thus commercial banks could respond to their profitability squeeze by abusing their lender of last resort and FDIC privileges to enable them to engage in activities that were increasingly similar to financial capitalist activities in general.

\section{Supplementing Profitability Beyond Traditional Commercial Bank Lending}

As commercial banks' found their profitability from lending activity had become more problematic, one of their response was to supplement their profits with income from sources other than interest on loans outstanding. Non-interest income became increasingly important for commercial banks throughout the 1980s and 1990s (see Figure 31). While in 1960 Commercial banks earned about 17 cents in non-interest income for every dollar of interest income earned, by the late 1990s this figure had risen to over 30 cents per dollar. The contribution of non-interest income is indicated in Figure 32. Figure 32 displays the total ROA of FDIC- member commercial banks, and the ROA calculated by excluding non-interest income. In every year since 1980 ROA would have been negative if non-interest income were excluded from the numerator of the ROA calculation. 
Figure 31: Non-Interest Income As A Percentage Of Interest Income For FDIC-Insured Commercial Banks, 1960-1999

Source Historical Statistics on Banking, CB04.

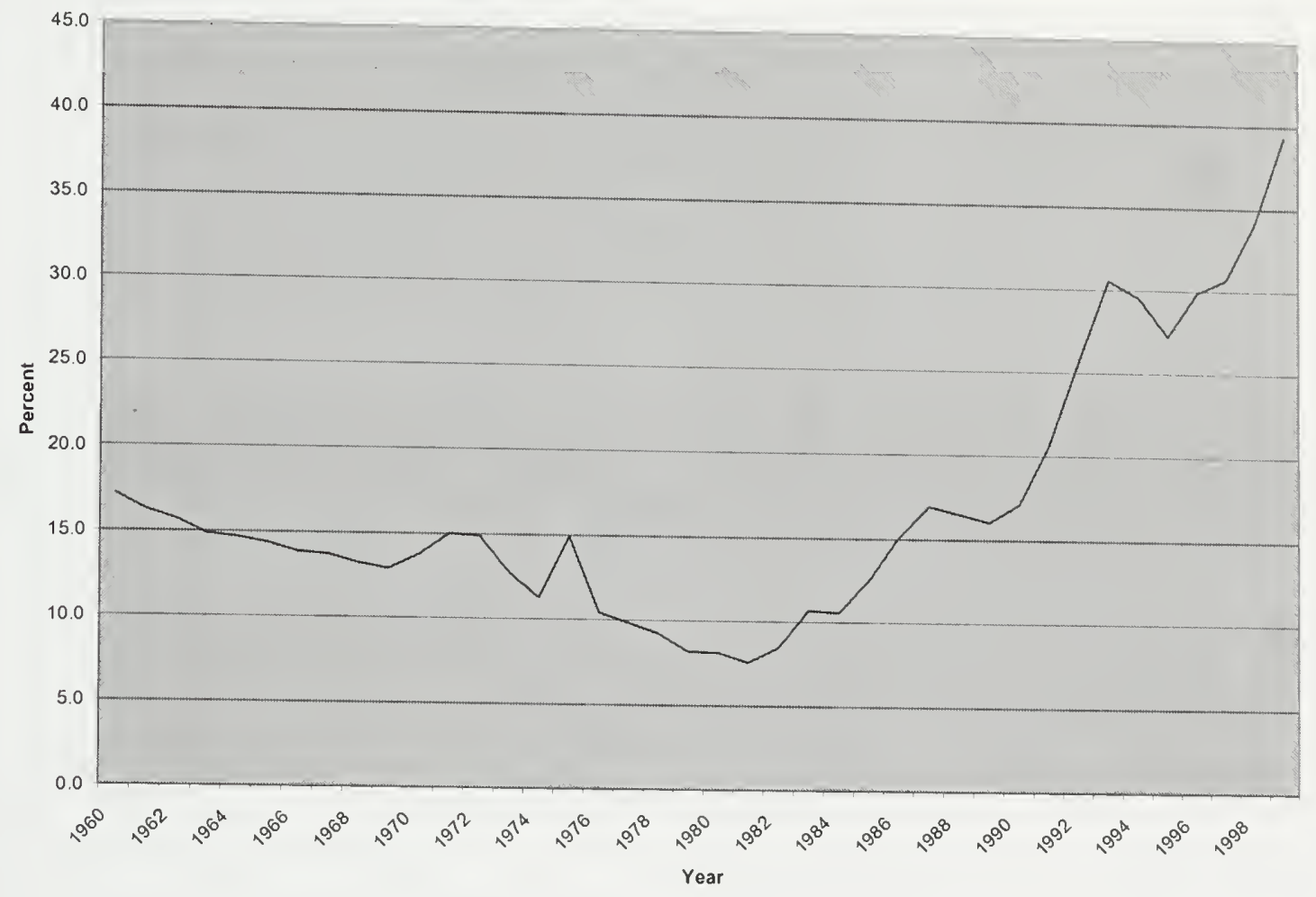


Figure 32: Return On Assets Of FDIC-Member Commercial Banks Including And Excluding Non-Interest Income, 1960-1999

Source: Historical Statistics on Banking, CB04.

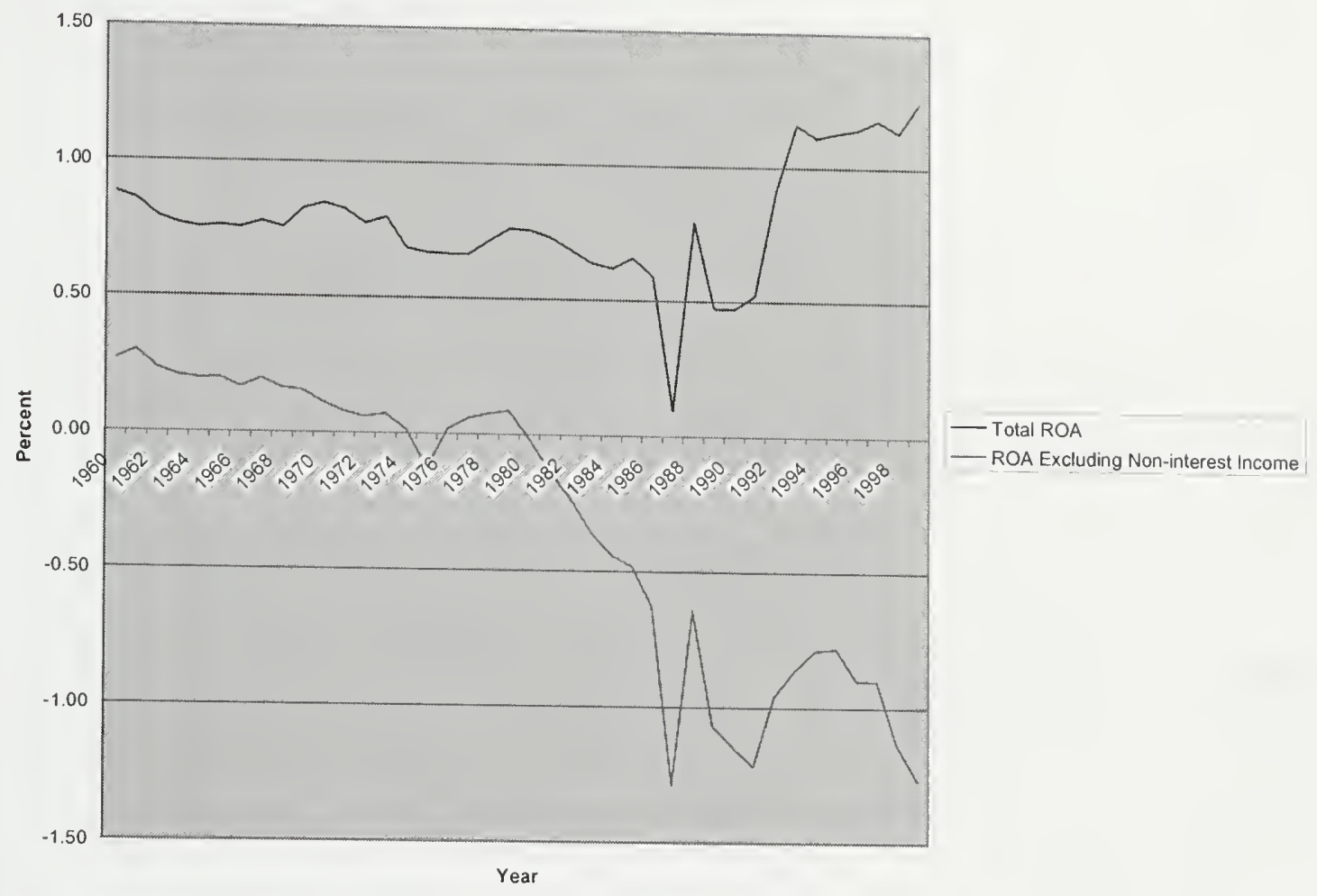

The wide array of activities that generate non-interest income provokes the question of how to deal with this category of income in class analytic terms. Chapter three assumed that non-interest income was a non-class revenue. Chapter three conceded that, upon investigation, some subset of these activities could arguably be classified as the production of a commodity. At this point, it may also be possible that the income generated by these activities is subsumed class revenue, in that in some instances a case can be made that these activities provide a condition of existence for capitalist exploitation. The issue of the class analytic categorization of these various forms of noninterest incomes will not be explored here. The preliminary assumption will be 
maintained that non-interest income is classified as a non-class revenue, with the caveat that specific inquiry may result in any of these instances of non-interest income being reclassified.

One of the sources of non-interest income for commercial banks is fee income. This includes fees charged for activities connected with the operation of a deposit account (for example, a fee might be levied on making withdrawals via an automatic banking machines). Sinkey claims that service charges on deposits grew at an annual rate of $7.7 \%$ between 1995 and 1999. (2002,470) Fees were also charged in association with lending activities in the second moment of financial intermediation (such as annual fees changed for the provision of credit cards). Moreover, fees were increasingly generated from some of the new financial innovations. For example, to enable a given deposit base to support more lending, commercial banks began to securitize aspects of their loan portfolio. Securitization involves gathering together loans (usually of a given type, such as mortgages and later credit card receivables and many other types of loans), packaging them as securities, and selling them (both the claims to the interest and the principal payments) to third parties. When the loans are securitized, they are moved off of the balance sheet of the bank, thus freeing up funds to finance new loans. However, the bank may retain the obligation to service the loans, thus it earns a fee for managing the collection of the payments on the variety of loans that back the security. This financial innovation not only assisted banks in their difficulties in the first moment of financial 
intermediation, it also enabled them to earn fees from their advantages in terms of their status in the payment system and their other comparative advantages in administering loans.

Many of the types of fee income generated by commercial banks had implications for the moral hazard issues discussed in the previous section. Banks increasingly earned fee income on various types of guarantees, such as lines of credit. A line of credit constitutes the promise to provide a loan should the potential borrower wish to have it. ${ }^{26}$ (Ironically, as chapter 6 explained, one of the unintended consequences of the growth in the provision of lines of credit was that it enabled competitors to commercial banks to raise money by stabilizing the commercial paper market). From a commercial bank's point of view, lines of credit are lucrative in that a fee may be earned even though no loan is ultimately provided. Yet lines of credit can also have a destabilizing influence on the commercial banking system. Lines of credit are often activated when a would-be borrower faces difficulty. Thus the commercial bank is obliged to advance a loan just at the point when the likelihood of default on the loan is high. Firms in distress often activate lines of credit prior to their failure, as was the case when Enron obliged several large banks to honor their lines of credit prior to its collapse. If several firms tap their lines of credit simultaneously and subsequently fail, this could threaten a commercial bank's survival. A crisis in one branch of productive capitalist activity can send these firms to activate their lines of credit just as that industry is in profound crisis. Detrimental economic events that adversely affect large numbers of firms simultaneously can provoke

\footnotetext{
${ }^{26}$ The fee for this stand-by arrangement is distinct from any interest income paid when and if the loan is actually provided.
} 
a widespread rush to activate lines of credit. By acting as a lender of last resort to any entity that has a line of credit, commercial banks themselves may require lender of last resort support, hence commercial banks have competitive advantage in the attempt to earn fee income from guarantees such as lines of credit. However, the Federal Reserve is exposed to the possibility that it may be prevailed upon to be the de facto lender of last resort to non-bank firms via the mechanism of commercial bank lines of credit that subsequently send commercial banks to the discount window.

Another area in which commercial banks generate fee income (as well as other types of off-balance sheet income) is by acting as a dealer of derivatives. Derivatives are a contract between two parties that provides the contract holder either the necessity (in a futures contract) or the possibility (in an option contract) of engaging in a transaction in the future whose value will be derived from the future values of some variable such as interest rates, exchange rates, equity or commodity prices or the occurrence of a host of other economic or non-economic events. For example, a bank may enter into a contract to pay a party a fixed rate of interest, while that party will pay the bank the prevailing rate on Treasury bills (applied to some notional amount which serves as the reference point from which the contract pay-out is calculated). The dealer will build into this transaction some margin which constitutes their fee, and is exposed to the possibility that the payout may be either more or less than the value the bank receives from the counterparty. 
Dealers in derivatives are exposed to a variety of risks. Ideally, derivatives dealers engage in matched trading, meaning that a derivatives contract that pays the counterparty if interest rates go up will be "matched" against another derivative that pays the bank in the same event. However, even if this matching strategy is scrupulously followed, there is credit risk inherent in many of these "over-the counter" ${ }^{27,}$ derivatives contracts. Although the dealer has matched two derivatives contracts so that the net effect on the derivatives trader is neutral, there is a possibility that one of the dealers' counterparties may default on the terms of their contract. In this event, the derivatives dealer continues to be exposed to the necessity of fulfilling the terms of the contract for the other "matched" counterparty. Thus potentially the counterparty whose derivatives contract benefits the dealer may default, while the derivative contract that is costly to the dealer remains in force. Moreover, this problem is intensified by the immense leveraging possible in derivatives. ${ }^{28}$ For example, at the time of its failure, Long Term Capital Management was reported to hold $\$ 1.25$ trillion of notional exposure in derivatives with an estimated value of $\$ 125$ billion, despite its own capital base being a mere $\$ 2.2$ billion. (Mehrling 1998,9) Finally, derivative dealers may intentionally expose themselves to risk, as when they establish a speculative position by refraining from balancing one derivatives contract with another matching derivative.

\footnotetext{
${ }^{27}$ Derivatives traded in organized futures exchanges have a clearing house guarantee to mitigate credit risk. (Edwards and Mishkin 1995, 15)

${ }^{28}$ Derivatives traded in over-the-counter markets have no standard collateral or margin requirements, despite the possibility that these provisions can be incorporated into the derivatives contracts.
} 
Eager to partake of the lucrative aspects of dealing in derivatives, the derivatives activities of US banks grew at a compound annual rate of about 20 percent between 1990 and 1999, until by 1999 US commercial banks held derivatives contracts with a notional value of $\$ 33$ trillion. ${ }^{29}$ However, the potential exposure of a derivatives dealer to both credit risk and other hazards related to the speculative use of derivatives can be enormously damaging. This helps to explain why derivatives dealing is often housed within a bank. Commercial banks benefit from their lender of last resort support to instill confidence in derivatives users that the dealer will be capable of fulfilling its contractual obligations despite a confluence of adverse developments. This further explains why only a handful of the largest US commercial banks are responsible for the bulk of derivatives dealing, since their status as "too-big-to-fail" bestows credibility on the likelihood of their access to lender of last resort support in a crisis. By 1992 the seven largest US banks accounted for more than 90 percent of all derivatives contracts held by US banks (Edwards and Mishkin 1995, 14), and the number of money-center banks that dominate derivatives dealing has dwindled further because of bank mergers in the late 1990s. However concern persists that interconnections among the largest banks active in the derivatives markets, in combination with the highly leveraged nature of many derivatives transactions, may create a calamity that devastates the major US commercial banks. As Warren Buffet famously commented,

We [his company, Berkshire Hathaway] try to be alert to any sort of megacatastrophe risk, and that posture may make us unduly apprehensive about the burgeoning quantities of long-term derivatives contracts and the massive amount of

\footnotetext{
${ }^{29}$ Greenspan (1999) claims that US commercial banks share of the global over-the-counter derivatives market is about $25 \%$, with US investment banks holding another $15 \%$.
} 
uncollateralized receivables that are growing alongside. In our view, however, derivatives are financial weapons of mass destruction, carrying dangers that, while now latent, are potentially lethal. (Buffet 2002, 16)

\section{Conclusion: The Illusory Pursuit of Stability}

This chapter has argued that one of the unintended consequences of the government safety net to promote the stability of the commercial banking system has been the negation of that agenda. As their profitability was squeezed, commercial banks increasingly used their access to deposit insurance and lender of last resort support to enable them to engage in a variety of activities that potentially compromise the stability of the commercial banking system. Worse still, the incentives to abuse this safety net were most enticing among the largest "money-center" banks, whose failure could most severely damage commercial banking stability. The details of the negation of this stabilizing project have been explored in this chapter to serve as an illustration of the impossibility of achieving stability from an overdeterminist perspective. While this chapter explored how a particular set of policies intended to promote stability were subverted, the intent is not to critique this set of policies with a view to devising some preferable set of policies that could be immune to negation. On the contrary, the intent is to bring into question the quest for stability itself.

While this chapter emphasized various sources of commercial bank instability, this analysis should not be construed as an argument that the history of commercial banking since the New Deal can be understood as a unidirectional movement towards instability. On the contrary, the rise of destabilizing impulses has provoked regulators, 
legislators and even commercial banks themselves to find new measures to promote stability. For example, as required reserves were attenuated as a stabilizing force in the commercial banking system, regulators sought ways of ensuring that banks had some backstop other than lender of last resort support. This helped to propel the 1988 Basel Accord, which imposed new capital adequacy regulations on commercial banks. The Basel standards required banks to have a certain level of capital based on the riskiness of their assets. Thus the sufficiency of bank capital, rather than required reserves, became viewed both as a source of liquidity to stem bank panics and a means of restraining wanton bank exposure to intensified risk. Another measure taken to retard excessive bank risk-taking was the introduction of risk-based fees for deposit insurance in the 1991 Comprehensive Deposit Insurance reform and Taxpayer Protection Act. To protect themselves against the devastating possibility of default in their increasingly risky activities, commercial banks had devised credit derivatives that enable a commercial bank to contract with other parties to make good on a defaulted contract (of course, in exchange for a fee).

While in some instances these newer measures have contributed to commercial bank stability, they in turn set in motion other ways in which may unintentionally contribute to instability. For example, the imposition of capital requirements has an unintended possibility of intensifying volatility. A commercial bank that enjoys a solid reputation will be easily able to acquire new capital, which allows commercial banks to expand lending dramatically during a prosperous times (particularly in stock market booms when securing equity capital is relatively easy). However, a bank facing a crisis will have great 
difficulty acquiring new capital to stabilize its operations. Risk-based deposit insurance premiums $^{30}$ and credit derivatives ${ }^{31}$ have also had unintended effects that may exacerbate instability in the commercial banking system and beyond.

From an overdeterminist perspective, this interplay between stabilizing and destabilizing dynamics is illustrates the illusiveness of stability. Whether stabilizing or destabilizing impulses are in the ascendancy in a particular overdetermined context, the negation of these impulses is also set in motion. Thus to the extent that the Keynesian agenda for economic growth and stability requires the stability of commercial banking, this overdeterminist analysis brings into question the possibility of sustaining this goal. As the Marxian tradition has pointed out in many contexts, the dynamics of the pursuit of profit in a competitive market imply instability of various sorts. While this point is argued frequently with reference to productive capitalist activity and the dynamics of exploitation, the endogeniety of instability is also characteristic of financial capitalist activity. Commercial banking in particular, and financial capitalist activity in general, will always have risks associated with it, as well as opportunities to profit by intensifying

\footnotetext{
${ }^{30}$ Risk-based deposit insurance premiums were intended to enhance the capacity of the FDIC to handle the expenses of bail-outs, and to act as a disincentive for commercial banks to engage in riskier activities. However, this regulation has favored large well-capitalized banks that were highly rated by banking supervisors. During the many years in which the Bank Insurance Fund is above a given level, large banks have been freed of the necessity of paying any deposit insurance premiums.

${ }^{31}$ By transferring default risk to third parities, credit derivatives create the possibility that a crisis in the commercial banking system may be transferred into a crisis among the counterparties in credit derivatives. Thus when, for example, insurance companies act as counterparties in credit derivatives, the Federal Reserve could be faced with a commercial banking crisis that manifests itself as a devastation of insurance companies.
} 
these risks. Thus any public policy with aspirations to promote stability will continuously be buffeted between the imperatives of promoting opportunities to pursue these profits, and containing the implications of the pursuit of these profits. 


\section{CONCLUSION}

This dissertation is written at a time in which numerous and provocative similarities exist between contemporary economic developments and the circumstances surrounding the implementation of the New Deal financial reforms. In the 1920s, as in the 1990 s, exuberance about a "new era" of cconomic prosperity culminated in a stock market bubble. In both periods, stock market euphoria was accompanied by a reorganization of financial capitalist activity and an increasing prevalence of diversified financial capitalist firms. In both the early 1930s and the early 2000 s, the stock market decline heralded a period of economic stagnation coupled with financial scandals (such as the fall of Enron in the contcmporary period). In many cases, these scandals were shaped by the various conflicts of interest animating diversified financial capitalist firms. These questionablc activities of diversified financial capitalist firms catalyzed public animosity towards finance, and created conditions in which financial reforms were again debated.

Bearing in mind these similarities between the depression-era animosity towards finance and contemporary financial critiques, an opportunity exists to inform the current strategic choices of the left by revisiting the earlier New Deal experiment with financial reforms. While the overdetermined context has changed dramatically from that which existed at the dawn of the New Deal, in some ways the intentions of contemporary progressive reformers to reshape finance in conformity with a larger leftist economic agenda shows remarkable continuity with this earlier period. In the New Deal era, as now, progressive financial reform initiatives have the potential to focus attention on 
finance at the expense of querying the specifically capitalist attributes of the economy.

While financial critiques could be raised in conjunction with the critique of exploitation, in many instances financial critiques are framed within an analysis that endorses the capitalist class process. The issues raised here is not whether financial reform should or should not be a component of a progressive agenda, but the implications of a progressive politics in which antipathy to finance eclipses critique of capitalism per se.

In an attempt to argue for the place of a class analytic anti-capitalism among the discourses of leftist transformation, this dissertation has studied New Deal financial reforms as a historical instance in which financial reforms were advanced devoid of any intention to challenge capitalism. On the contrary, these reforms were motivated to remedy the flaws in capitalism to enable it to sustain vigorous and stable economic growth. From a Marxian class analytic perspective, this project of financial reform is reprehensible in two respects. First, despite the many progressive characteristics that might be incorporated into this economic agenda, it sought to provide the conditions of existence for continued capitalist exploitation. Secondly, these reforms embodied a determinist logic, in that they sought to implement policy measures deigned to remedy certain defects that were seen as the essential impediments to stable capitalist prosperity.

In order to critique New Deal financial reforms from an overdeterminist Marxian class analytic perspective, this dissertation emphasizes the contradictions inherent in this project of securing the financial conditions of existence of a stable capitalist growth. Particular emphasis has been made on the ways in which the contradictory imperatives of 
New Deal financial reform interacted with the profit-maximizing strategies of financial capitalist firms. We examine how these policies sought to achieve their desired objectives, and how, thanks in part to actions of capitalist firms seeking to manipulate these contradictions, they simultaneously set in motion developments that subverted their desired objectives. The dissertation presents the case that, in some respects, the pastiche of policies implemented by New Deal financial reforms helped to secure the financial conditions of existence of the stability of pax financus and the economic growth characteristics of the golden age of Keynesian welfare state capitalism. Yet paradoxically, these policies also set in motion the negation of these achievements. Conditions were promoted that in some ways moderated and in some ways raised the subsumed class payment for access to money capital. In some ways the commercial banking system was stabilized by New Deal financial reforms, and in some ways this stability was further compromised.

What then can be the contribution of this economic history? It illustrates that New Deal policies are animated by contradiction, but then, following overdeterminist logic, everything is necessarily contradictory. This dissertation seeks to promote an awareness of the ubiquity of contradiction in order to problematize the rejection of overdetermination implicit in the search for some ideal policy configuration that could escape contradiction. The stated motivation of the dissertation is to promote a radical, class analytic Marxist alliance. and I consider the relentless search for policy optimality to be inimical to this proposed alliance. So long as we are persuaded that radicals have failed to achieve their objective because of some flaws in the policies they endorsed, then 
leftists will be engaged in the continuous refinement of their policy mix in hopes of achieving their aims. This focuses leftist aspirations on what is, from an overdeterminist perspective, a Sisyphean task. Thus an analysis of the inherent contradictions of the New Deal is offered to persuade radicals to abandon an illusory quest for the ideal reforms.

However, leftists contemplating an alliance with class analytic Marxism should note that the embrace of overdetermination also abolishes any comforting assurance that the inclusion of an anti-capitalist agenda will produce interventions that necessarily have a greater likelihood of achieving their desired non-class ends. Overdetermination implies that, since all intervention is contradictory (and hence implies its own negation), it follows that the inclusion of the Marxian surplus labor agenda with other radical agendas can offer no claim that the resulting transformative project will be any less (or any more) contradictory than were the New Deal financial reforms. Thus overdeterminist Marxism can not offer guarantees that such an alliance will increase (or for that matter decrease) the possibility of the success of radical non-class agendas. It can make the case that the perpetuation of exploitative class relationships has detrimental consequences for the nonclass economic agendas of radicals, and that a variety of democratic and egalitarian aspirations have been continuously frustrated under capitalism. However overdeterminist Marxism cannot deny that its own theory of causation precludes any appeal to the inevitable triumph of radical agendas once the prevalence of non-exploitative production arrangements is established. Overdeterminist Marxism can only offer the commitment to 
struggle on behalf of a radical coalition agenda, which, from an overdeterminist perspective, is the only commitment that can be made on behalf of any political intervention. 


\section{BIBLIOGRAPHY}

Angermueller, Hans. "The Customer is Always Right: The Case for Functional

Regulation of Financial Services." In Merging Commercial And Investment

Banking, ed. Federal Reserve Bank of Chicago, 1-10. Chicago: Federal Reserve Bank of Chicago, 1987.

Benston, George. The Separation of Commercial and Investment Banking: The GlassSteagall Act Revisited and Reconsidered. New York: Oxford University Press, 1990.

Berle, Adolph. The Future of American Banking. Lake George, New York: New York State Bankers Association, 1933.

Board of Governors of the Federal Reserve System. Banking And Monetary Statistics. Washington: Federal Reserve, 1943.

Bradford, Terri, Matt Davies, and Stuart Weiner. Nonbanks In the Payments System [online]. Federal Reserve Bank of Kansas City, 2003. Available from the World Wide Web: (www.kc.frb.org/FRFS/NonBankPaper.pdf)

Buffet, Warren, "Chairman's Letter", 2002 Anmual Report of Berkshire Hathaway Inc. [online] Available from the World Wide Web (www.berkshirehathaway.com)

Burns, Helen. The American Banking Community and the New Deal Banking Reforms, 1933-1935. Westport Connecticut: Greenwood Press, 1974.

Carosso, Vincent. Investment Banking In America: A History. Cambridge: Harvard University Press, 1970.

Congressional Budget Office. The Changing Business of Banking: A Study of Failed Banks from 1987 to 1992. Washington DC: Congressional Budget Office, 1994.

Corrigan, Gerald E. “Are Banks Special?" In Annual Report: Federal Reserve Bank of Minneapolis. Minneapolis: Federal Reserve Bank of Minneapolis, 1982.

Crotty, James. "Are Keynesian Uncertainty and Macrotheory Incompatible?

Conventional Decision Making, Institutional Structures and Conditional Stability In Keynesian Macromodels." In New Perspectives In Monetary Macroeconomics: Explorations In the Tradition of Hyman Minsky, eds. Gary Dymski and Robert Pollin, 105-142. Ann Arbor: University of Michigan Press, 1994.

. "Was Keynes a Corporatist? Keynes' Radical Views on Industrial Policy and Macro Policy In the 1920s." Journal of Economic Issues, 33 (1999): 555-577. 

d'Arista, Jane. The Evolution of US Finance, Volume Two. Armonk, New York: M.E.
Sharpe, 1993.

d'Arista, Jane W and Tom Schlesinger. "The Emerging Parallel Banking System." In The Financial Services Revolution, ed. Clifford Kirsch, 485-504. Chicago: Irwin Professional Publishing, 1997.

. "The Parallel Banking System." In Transforming the US Financial System. eds. Gary Dymski, Gerald Epstein and Robert Pollin, 157-199. Armonk: M.E. Sharpe, Inc. 1993.

de Saint Phalle, Thibaut. The Federal Reserve: An Intentional Mystery. New York: Praeger, 1985.

Duncan, Martha C. and Walter Ashby, Pat Cowherd, Eric Dahlstrom II, Kathleen Frantum, Diane Geeslin Bunch, Greg Haag, Philip M. Robertson, and Roan, Margo Stanley, Gregory Watson. The Root Causes of Bank Failures [online]. Federal Deposit Insurance Corporation, 2003. Available from the World Wide Web: (www.swgsb.org/fdic/fdicl.pdf)

Edwards, Franklin and Frederic Mishkin. The Decline Of Traditional Banking:

Implications For Financial Stability And Regulatory Policy. Cambridge: National Bureau of Economic Research, Working Paper No. 4993, 1995.

Edwards, George. The Evolution of Finance Capitalism. New York: Augustus M. Kelly, 1967.

Epstein, Gerald And Thomas Ferguson, "Monetary Policy, Loan Liquidations And Industrial Conflict: The Federal Reserve And The Open Market Operations Of 1932". The Journal of Economic History, 44 (1984): 957-983.

Feinman, Joshua. "Reserve Requirements: History, Current Practice and Potential Reform" [online]. Federal Reserve Bank, undated. Available from the World Wide Web: (www.federalreserve.government/monetarypolicy/0693lead.pdf)

Federal Deposit Insurance Corporation, A Brief History of Deposit Insurance In the United State [online]. 1998. Available from the World Wide Web: (www.fdic.gov/bank/historical/brief/brhist.pdf)

. Historical Statistics on Banking [online]. Available from the World Wide Web: (www2.fdic.gov/hsob/SelectRpt.asp?EntryTyp=10)

. History of the Eighties- Lessons for the Future:An Examination of the Banking Crises of the 1980s and Early 1990. [online]. Washington D.C., December 1997. Available from the World Wide Web: (www.fdic.gov/bank/historical/history/contents.html) 
Federal Reserve Flow of Funds Accounts of the United States, Annual Flows and Outstandings [online]. Available from the World Wide Web:

(www.federalreserve.gov/releases/z1/current/data.htm)

Ferraro, Vincent and Melissa Rosser. "Global Debt and Third World Development." In World Security: Challenges for a New Century, eds. Micheal Klare and Daniel Thomas, 332-355. New York: St. Martin's Press, 1994.

Fischer, Gerald. American Banking Structure. New York: Columbia University Press, 1968.

Frankel, Tamar. "Securitization of Loans: Asset-backed Securities and Structured Financing." In The Financial Services Revolution, ed. Clifford Kirsch, 215-233. Chicago: Irwin Professional Publishing, 1997.

Friedman, Milton and Anna Schwartz. A Monetary History of the United States 18671960. Princeton: Princeton University Press, 1963.

Fusfeld, Daniel. The Economic Thought Of Franklin D. Roosevelt And The Origins Of The New Deal. New York: Columbia University Press, 1956.

Galbraith, John. The Great Crash. Boston: Houghton Mifflin, 1955.

Gart, Alan. Regulation, Deregulation, Reregulation: The Future of the Banking, Insurance and Securities Industries. New York: John Wilely and Sons Inc., 1994.

Grabel, Ilene. "Speculation" In Encyclopedia of Political Economy, Volume Two. ed. Phillip O’Hara, 1076-1079. New York: Routledge, 1999.

Greer, Thomas. What Roosevelt Thought: The Social and Political Ideas of Franklin D. Roosevelt. East Lansing: Michigan State University Press, 1958.

Greenspan, Alan. Our Banking History [online]. Remarks Before the Annual Meeting and Conference of the Conference of State Bank Supervisors, Nashville, Tennessee. May 2, 1998. Available from the World Wide Web: (www.federalreserve.gov/boarddocs/speeches/1998/19980502.htm)

Grieder, William. Secrets of the Temple: How the Federal Reserve Runs the Country. New York: Simon and Schuster, 1987.

Hammond, Bray. "Historical Introduction." In Banking Studies, ed. Members of the Staff of the Board of Governors of the Federal Reserve System, 39-64. Baltimore: Waverly Press, 1941. 
Hayes, Samuel, "Introduction." In Wall Street and Regulation, ed. Samuel Hayes, 1-6. Boston: Harvard Business School Press, 1987.

Hilferding, Rudolf. Finance Capital: A Study Of The Latest Phase Of Capitalist Development. Boston: Routledge and Kegan, 1981.

Helleiner, Eric. States and the Reemergence of Global Finance. Ithaca: Cornell University Press, 1994.

Hubbard, Glenn. Money, the Financial System and the Economy. $2^{\text {nd }}$ ed. New York: Addison Wesley Longman Inc., 1996.

Humphries, Hubert. The Political Philosophy of the New Deal. Baton Rouge: Louisiana State University Press, 1970.

Hyman, Sidney. Marriner S. Eccles: Private Entrepreneur And Public Servant. Stanford: Graduate School of Business, Stanford University, 1976.

Kaufman, George and Larry Mote. "Commercial Bank Securities Activities: What Really Happened In 1902: Note." Journal of Money, Credit and Banking, 24 (1992): 370-374.

Kennedy, Susan. The Banking Crisis of 1933. Kentucky: University of Kentucky Press, 1973.

Keynes, John Maynard. The General Theory of Employment, Interest and Money. Cambridge: Cambridge University Press, 1973.

. "An Open Letter to President Roosevelt by John Maynard Keynes, December 31, 1933." In Documentary History of Banking and Currency In the United States, Volume Four. ed. Herman Krooss, 2786-2788. New York: McGraw Hill, 1969.

A Treatise on Money, Volume Two. Edinburgh: R.\&R. Clark, 1930.

Kimpel, John. "Mutual Fund Investments In Participant-Directed Retirement Plans" In The Financial Services Revolution, ed. Clifford Kirsch, 255-273. Chicago: Irwin Professional Publishing, 1997.

Klebaner, Benjamin. American Commercial Banking: A History. Boston: Twayne Publishers, 1990.

. Commercial Banking In The United States: A History. Illinois: The Dryden Press 1974. 
Kotz, David. Bank Control of Large Corporations In the United States. Berkeley: University of California Press, 1978.

Krainer, John. "The Separation of Banking and Commerce" Economic Review [online]. Federal Reserve Bank of San Francisco, 2000: 15- 24 Available from the World Wide Web: (www.frbsf.org/econrsrch/econrev/2000/article2.pdf)

Krooss, Herman. Documentary History of Banking and Currency In the United States, Volume Four. New York: McGraw Hill, 1969.

Krooss, Herman and Martin Blyn. A History of Financial Intermediaries. New York: Random House, 1971.

Kroszner, Randall. "The Legacy of the Separation of Banking and Commerce Continues In Gramm-Leach-Bliley."The Region [online]. June 2000. Available from the World Wide Web: (www.minneapolisfed.org/pubs/region/00-06/kroszner.cfm)

Lenin, Vladimir. Imperialism, The Highest Stage of Capitalism. Peking: Foreign Languages Press, 1975.

Marx, Karl. Capital, Volumes One and Three. New York: International Publishers, 1967.

Mason, James Elliot. The Transformation Of Commercial Banking In The United States, 1956-1991. New York: Garland Publishing, Inc. 1997.

Mayer, Martin. The Fed. New York: Penguin Books, 2001.

.The Bankers: The Next Generation. New York: Truman Talley Books/Plume, 1997.

Mayer, Thomas, James Duesenberry and Robert Aliber. Money Banking and the Economy, $2^{\text {nd }}$ ed. New York: W.W. Norton And Company, 1984.

Meerschwam, David. "Breaking Relationships: The Advent of Price Banking in the United States." In Wall Street and Regulation, ed. Samuel Hayes, 63-96. Boston: Harvard Business School Press, 1987.

Mehrling, Perry. "Minsky, Modern Finance, and the Case of Long Term Capital Management". Presentation at the conference "The Legacy of Hyman P. Minsky" December 11-12 1998 at the University of Bergamo Italy.

Members of the Staff of the Board of Governors of the Federal Reserve System. "Tables." In Banking Studies, ed. Members of the Staff of the Board of Governors of the Federal Reserve System, 417- 460. Baltimore: Waverly Press, 1941. 
Modigliani, Franco and Merton Miller. "The Cost of Capital, Corporate Finance, and the Theory of Investment." American Economic Review, 48 (1958): 261-297.

Myers, Margaret. A Financial History of the United States. New York: Columbia University Press, 1971.

O'Connor, J.F.T. The Banking Crisis And Recovery Under The Roosevelt Administration. Chicago: Callaghan and Company, 1938.

Peach, Nelson. The Security Affiliates of National Banks. Baltimore: The John Hopkins Press, 1941.

Pecora, Ferdinand. Wall Street Under Oath. New York: Simon and Schuster, 1939.

Perkins, Edwin J. "The Divorce Of Commercial And Investment Banking: A History." The Banking Law Journal. 88 (1971): 483-528. .

Resnick, Stephen and Richard Wolff. Knowledge and Class. Chicago: The University of Chicago Press, 1987.

Roussakis, Emmanuel. Commercial Banking In an Era of Deregulation. Westport Connecticut: Praeger Publishers, 1997.

Roosevelt, Franklin. "Bold Persistent Experimentation.” In New Deal Thought, ed. Howard Zinn, 77-83. Howard Indianapolis: Bobbs-Merrill, 1966.

Sachs, Jeffrey and Harry Huizinga. "U.S. Commercial Banks and the DevelopingCountry Debt Crisis." Brookings Papers on Economic Activity, 1987 (1987): 555601.

Schwartz, Jordan. Liberal: Adolph A. Berle and the Vision of an American Era. New York: The Free Press, 1987.

Shutt, Harry. The Trouble with Capitalism. New York: Zed Books, 1998

Sinkey, Joseph. Commercial Bank Financial Management, $6^{\text {th }}$ ed. New Jersey: Prentice Hall, 2002.

Thomas, Norman. "The 30s as a Socialist Recalls Them." In As We Saw The Thirties; Essays On Social And Political Movements Of A Decade, ed. Rita James Simon, 102-122. Urbana: University of Illinois Press, 1967.

U.S. Congress. House of Representatives. Representative Patman speaking for the adoption of the Reconstruction Finance Commission model in today's economy, In Congressional Record. August 4, 1969, 22118-22124. 
Vietor, Richard. "Regulation-Defined Financial Markets: Fragmentation and Integration In Financial Services." In Wall Street and Regulation, ed. Samuel Hayes, 7-62. Boston: Harvard Business School Press, 1987.

Wolfson, Martin. Financial Crisis: Understanding the Postwar US Experience, $2^{\text {nd }}$ ed. Armonk, New York M.E. Sharpe. 1994.

Wooten, James A. "The Most Glorious Story of Failure In the Business: The StudebakerPackard Corporation and the Origins of ERISA." Buffalo Law Review, 49 (2001):
683 - 739 .

Wyatt, Walter. "Federal Banking Legislation." In Banking Studies, ed. Members of the Staff of the Board of Governors of the Federal Reserve System, 39-64. Baltimore: Waverly Press, 1941. 



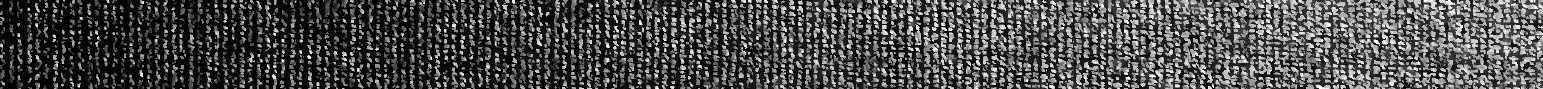

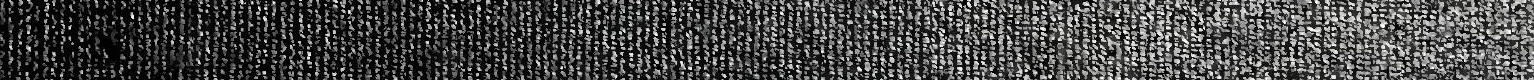

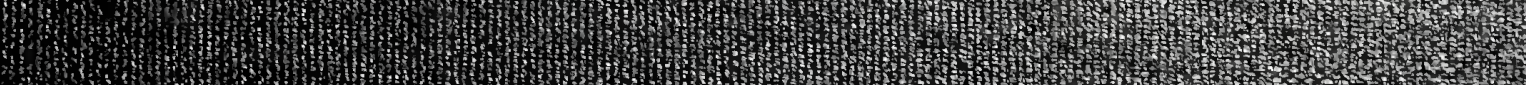
W.

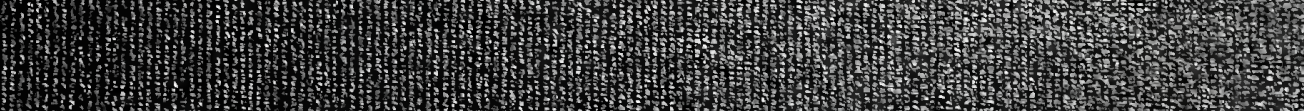

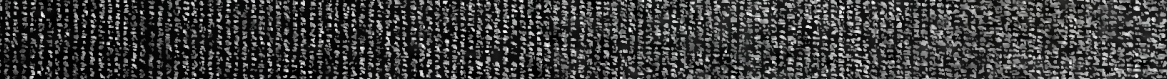

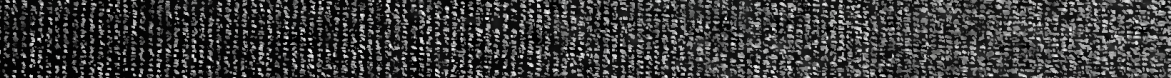

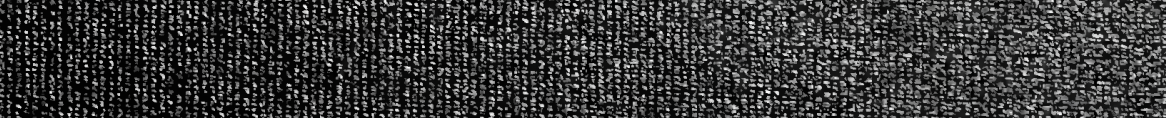

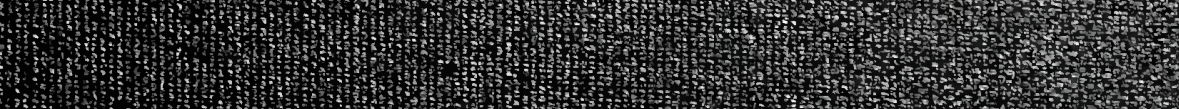

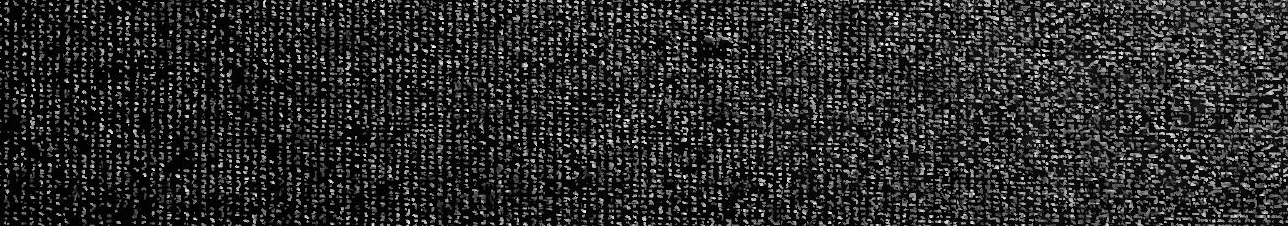

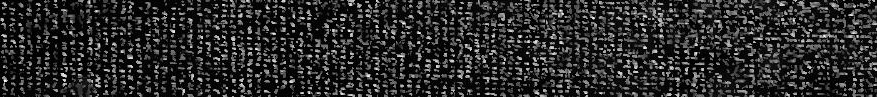
\begin{tabular}{|c|c|c|c|c|c|}
\hline &
\end{tabular}

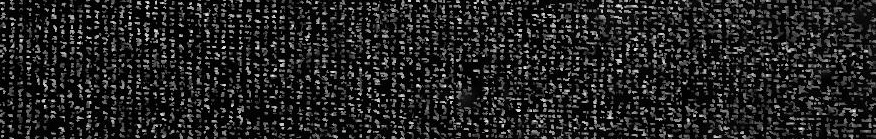

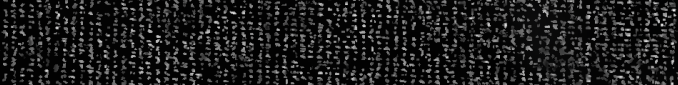
X. ton

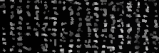

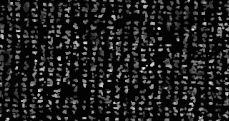

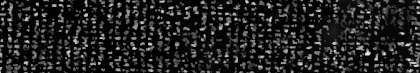

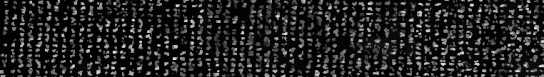

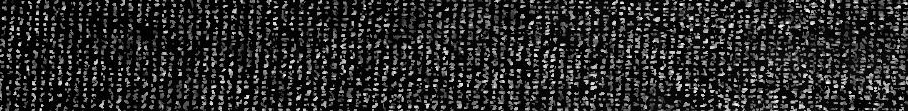

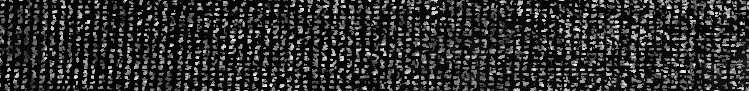

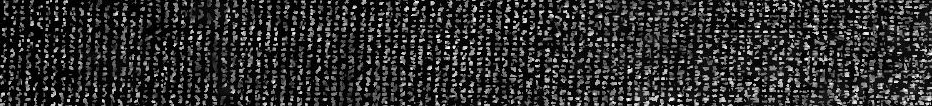
H, W

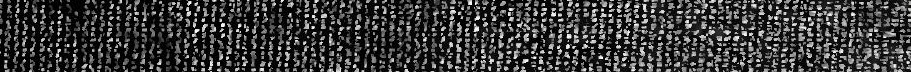
Whm

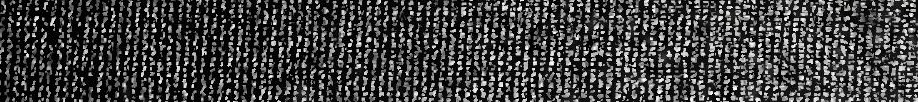
Wh- 